Welcome to the electronic edition of The Sound of William Barnes's Dialect Poems: 2. Poems of Rural Life in the Dorset Dialect, second collection (1859).

The book opens with the bookmark panel and you will see the contents page. Click on this anytime to return to the contents. You can also add your own bookmarks.

Each chapter heading in the contents table is clickable and will take you direct to the chapter. Return using the contents link in the bookmarks.

The whole document is fully searchable.

Enjoy.

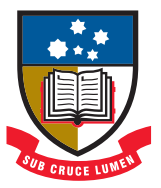

THE UNIVERSITY

of ADELAIDE 


\title{
The Sound of
}

\section{William Barnes's Dialect Poems}

\author{
2. Poems of Rural Life in the Dorset Dialect, \\ second collection (1859)
}

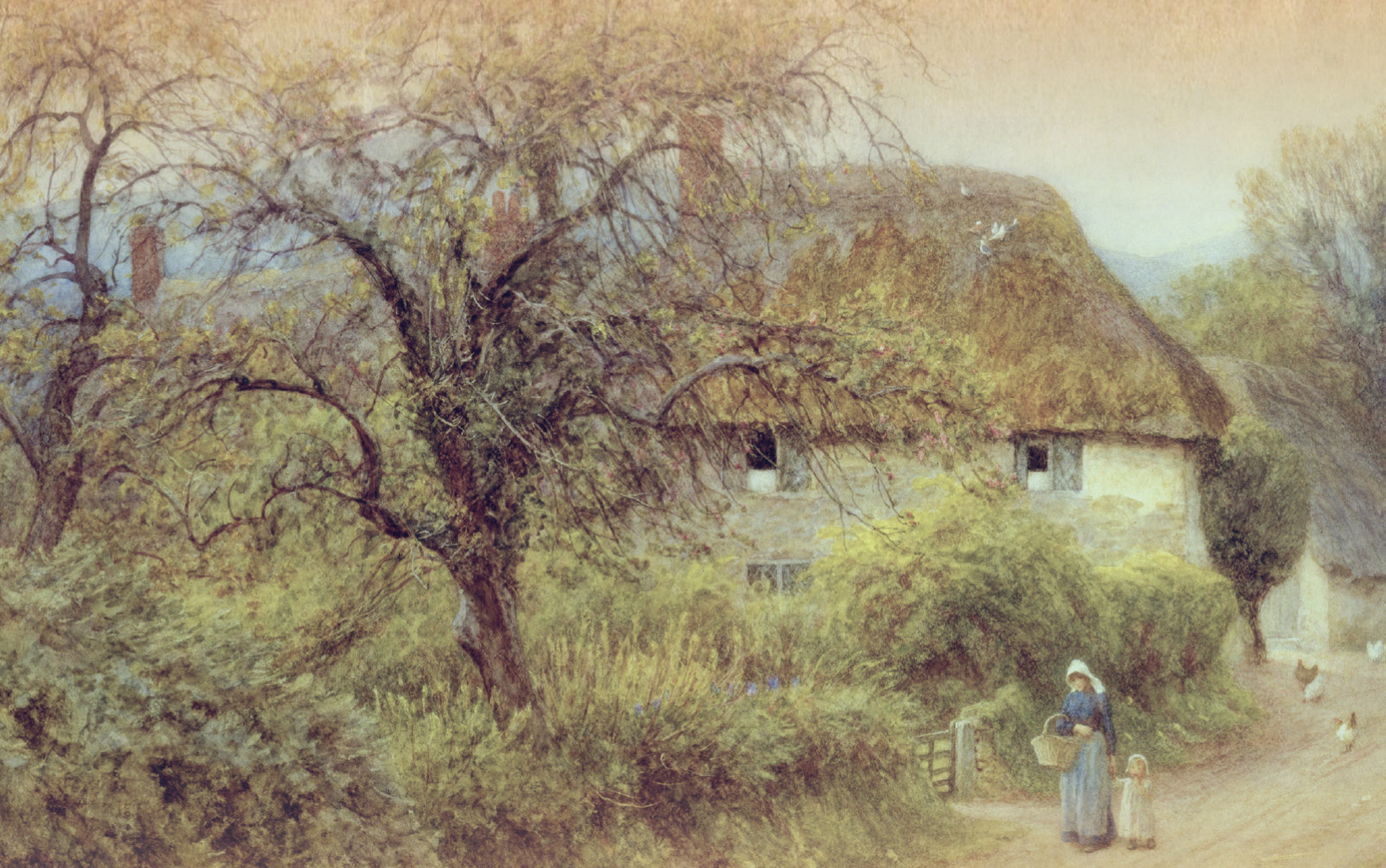

by T.L. Burton 


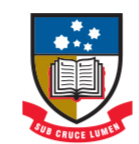

THE UNIVERSITY of ADELAIDE

UNIVERSITY OF ADELAIDE PRESS

\section{The Sound of William Barnes's Dialect Poems}

2. Poems of Rural Life in the Dorset Dialect, second collection (1859)

by T. L. Burton

From reviews of Volume 1 of The Sound of William Barnes's Dialect Poems:

This volume is the first of a series designed to supplement Burton's William Barnes's Dialect Poems: A Pronunciation Guide (2010) ... Together, these volumes constitute a monumental project which "sets out to provide a phonemic transcript and an audio recording of each individual poem in Barnes's three collections of Poems of Rural Life in the Dorset Dialect" ...

The driving force behind this project is Burton's enthusiasm for Barnes's work and his desire to bring these poems to life for the widest possible audience ... Recordings of Burton's lively, animated and accurate readings of each poem are provided on a free website hosted by Adelaide University Press, as is a free, searchable pdf version of the text ...

The Sound of William Barnes's Dialect Poems can ... be used by those without access to the Pronunciation Guide; so the pdf version effectively constitutes a free, comprehensive guide to Barnes's pronunciation, something for which both the author and the publisher are to be applauded.

-Joan C. Beal in Anglia.
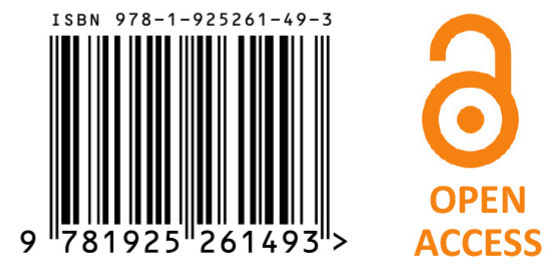

This book is available as a free ebook from adelaide.edu.au/press

Cover design by Emma Spoehr Cover image by Helen Allingham (1848-1926) 


\section{The Sound of}

William Barnes's Dialect Poems

2. Poems of Rural Life in the Dorset Dialect, second collection 


\section{About this volume}

This is the second volume in a series that sets out to to provide a phonemic transcript and an audio recording of each individual poem in Barnes's three collections of Poems of Rural Life in the Dorset Dialect. Beginning with two poems that inspired Vaughan Williams to set them to music, and ending with a paean of praise for the poet's native county, this second collection contains 105 poems of immense range and power. There are poems of longing, of love and of loss; of pain and of protest; of tears and of laughter; of grief and consolation; of feasting and celebration; of music and birdsong; of falsehood and friendship and faith; of generosity and meanness; of bad temper and good; of stasis and travel; of flowers and trees; of storm and of calm. "Here," in short, (as Dryden famously said of the poetry of Geoffrey Chaucer) "is God's plenty".

T. L. Burton is an Emeritus Professor of English at the University of Adelaide.

Free audio files of T. L. Burton performing the poems in this book are available from

www.adelaide.edu.au/press/titles/barnes-vol-2/recordings

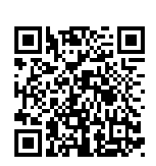

This book is available as a free fully-searchable PDF from www.adelaide.edu.au/press 


\section{The Sound of}

\section{William Barnes's Dialect Poems}

2. Poems of Rural Life in the Dorset Dialect, second collection (1859)

as revised for the final collection (1879)

by

T. L. Burton

Department of English and Creative Writing

School of Humanities

The University of Adelaide

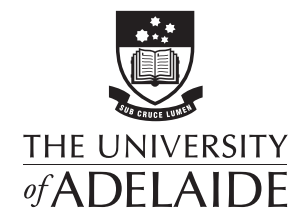

UNIVERSITY OF

ADELAIDE PRESS 
Published in Adelaide by

University of Adelaide Press

Barr Smith Library

The University of Adelaide

South Australia 5005

press@adelaide.edu.au

www.adelaide.edu.au/press

The University of Adelaide Press publishes externally refereed scholarly books by staff of the University of Adelaide. It aims to maximise access to the University's best research by publishing works through the internet as free downloads and for sale as high quality printed volumes.

\section{(C) 2017 T. L. Burton}

This work is licenced under the Creative Commons Attribution 4.0 International (CC BY-NC-ND 4.0) License. To view a copy of this licence, visit http://creativecommons.org/licenses/by/4.0/ or send a letter to Creative Commons, 444 Castro Street, Suite 900, Mountain View, California, 94041, USA. This licence allows for copying any part of the work for personal and commercial use, providing author attribution is clearly stated. Address all inquiries to the Director at the above address.

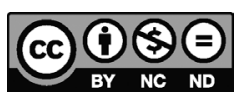

For the full Cataloguing-in-Publication data please contact the National Library of Australia:

cip@nla.gov.au

ISBN (paperback) 978-1-925261-49-3

ISBN (ebook) 978-1-925261-50-9

DOI: http://dx.doi.org/10.20851/barnes-vol-2

Cover illustration: A Hill Farm, Symondsbury, Dorset (w/c on paper), Allingham, Helen (1848-1926) / Private Collection / The Bridgeman Art Library

Cover design: Emma Spoehr

Paperback printed by Griffin Press, South Australia 


\section{CONTENTS}

Preface

ix

Abbreviations

xi

Key to phonetic symbols

$\mathrm{XV}$

Alternative pronunciations

xvi

Table of common alternatives

xvii

Introduction

The spelling and pronunciation of the modified form of the dialect

Chief differences in spelling between the broad form of the dialect in 1844 and the modified form in 1879

A note on the text

"Childhood": a line-by-line phonemic analysis

Second-Collection Poems with phonemic transcripts

Blackmwore maïdens

My orcha'd in Lindèn Lea

Bishop's Caundle

Haÿ meäkèn—nunchen time

A father out, an' mother hwome 54

Riddles 58

Day's work a-done 66

Light or sheäde 70

The waggon a-stooded 72

Gwaïn down the steps vor water 80

Ellen Brine ov Allenburn

The motherless child 88

The leädy's tower

Fatherhood

The Maïd o' Newton 106

Childhood

Meäry's smile

Meäry wedded

The stwonen bwoy upon the pillar 
The young that died in beauty

Fair Emily of Yarrow Mill

The scud

Mindèn house

The lovely maïd ov Elwell Meäd

Our fathers' works

The wold vo'k dead

Culver Dell and the squire

Our be'thplace

The window freämed wi' stwone

The water-spring in the leäne

The poplars

The linden on the lawn

Our abode in Arby Wood

Slow to come, quick agone

The vier-zide

Knowlwood

Hallowed pleäces

The wold wall

Bleäke's house in Blackmwore

John Bleäke at hwome at night

Milkèn time

When birds be still

Ridèn hwome at night

Zun-zet

Spring

The zummer hedge

The water crowvoot

The lilac

The blackbird [II]

The slantèn light o' fall 238

Thissledown

The maÿ-tree

Lydlinch bells

The stage coach 
Wayfeärèn

The leäne

The railroad [I]

The railroad [II]

Seats

Sound o' water

Trees be company

A pleäce in zight

Gwaïn to Brookwell

Brookwell

The shy man

The winter's willow

I know who

Jessie Lee

True love

The beän vield

Wold friends a-met

Fifehead

Ivy Hall

False friends-like

The bachelor

Married peäir's love walk

A wife a-praï'd

The wife a-lost

The thorns in the geäte

Angels by the door

Vo'k a-comèn into church

Woone rule

Good Meäster Collins

Herrenston

Out at plough

The bwoat

The pleäce our own ageän

Eclogue: John an' Thomas 380

Pentridge by the river 
Wheat

The meäd in June

Early risèn

400

Zellèn woone's honey to buy zome'hat sweet

Dobbin dead

406

Happiness

410

Gruffmoody Grim

414

The turn o' the days

420

The sparrow club

424

Gammony Gaÿ

428

The heäre

434

Nanny Gill

438

Moonlight on the door

442

My love's guardian angel

446

Leeburn Mill 450

Praïse o’ Do'set 454

Textual notes

Appendix: A summary of sections 7 and 8 of $W B P G$ 


\section{PREFACE}

This is the second volume in a series that sets out to provide a phonemic transcript and an audio recording of each poem in Barnes's three collections of Poems of Rural Life in the Dorset Dialect.

The individual volumes in the series are not designed to be critical editions: they do not contain variant readings from different versions of the poems or detailed notes on matters of linguistic, literary, social, historical, or biographical interest. The aim is simply to provide a self-contained, uncluttered, and reader-friendly text, which may be read on-screen or on the page, with marginal glosses for any words or phrases that might cause difficulty, together with audio recordings that may be freely audited online.

In addition to the many kind friends whose help is acknowledged in the Pronunciation Guide from which this series derives I wish particularly to thank John Emerson, Director of the University of Adelaide Press, and his staff, for their unshakeable patience and their staunch support. 



\section{ABBREVIATIONS}

1844

1847

1863 Grammar

1879

1886 Glossary

$a d v$.

AED

C

CS

cwl

DCC

Diss.

DWS
The first edition of Barnes's first collection of dialect poems, Poems of Rural Life, in the Dorset Dialect: With a Dissertation and Glossary (1844)

The second edition of Barnes's first collection of dialect poems (1847)

Barnes's A Grammar and Glossary of the Dorset Dialect with the History, Outspreading, and Bearings of South-Western English. Berlin: A. Asher for The Philological Society, 1863. Barnes's Poems of Rural Life in the Dorset Dialect. London: C. Kegan Paul, 1879 (containing the first, second, and third collections of Poems of Rural Life brought together in one volume.)

Barnes's A Glossary of the Dorset Dialect with a Grammar of Its Word Shapening and Wording. Dorchester: M. \& E. Case, County Printers; London: Trübner, 1886.

adverb

Upton, Clive, and J. D. A. Widdowson. An Atlas of English Dialects. 2nd ed. London: Routledge, 2006.

Consonant

Comparative Specimen (in Part 5 of Ellis's On Early English Pronunciation)

Classified Word List (in Part 5 of Ellis's On Early English Pronunciation)

\section{Dorset County Chronicle}

The "Dissertation on the Dorset Dialect of the English Language" prefaced to 1844

Elworthy, Frederic Thomas. "The Dialect of West Somerset." Transactions of the Philological Society (1875-76): 197-272. English Dialect Society, Series D, Miscellaneous, 7. London: Trübner, 1875. 
EDD

EEP

Ellis

$\mathrm{eMnE}$

GenAm

Jennings

Jones

$L A E$

later editions

MacMahon

$\mathrm{ME}$

$\mathrm{OE}$

$O E D$

ppl.
The English Dialect Dictionary: Being the Complete Vocabulary of All Dialect Words Still in Use, or Known to Have Been in Use during the Last Two Hundred Years; Founded on the Publications of the English Dialect Society and on a Large Amount of Material Never Before Printed. Ed. Joseph Wright. 6 vols. London: H. Frowde; New York: G. P. Putnam's, 1898-1905.

On Early English Pronunciation (see Ellis)

Ellis, Alexander J. On Early English Pronunciation, with Especial Reference to Shakespere and Chaucer ... 5 parts. Early English Text Society, Extra Series 2, 7, 14, 23, 56. London: Trübner, 1867, 1869, 1871, 1874, 1889. early Modern English (roughly 16th \& 17th centuries) General American (pronunciation) Jennings, James. Observations on Some of the Dialects in the West of England, Particularly Somersetshire: With a Glossary of Words Now in Use There; and Poems and Other Pieces Exemplifying the Dialect. London: Printed for Baldwin, Cradock, and Joy, 1825.

Jones, Daniel. An Outline of English Phonetics. Leipzig: Teubner, 1918.

The Linguistic Atlas of England. Ed. Harold Orton, Stewart Sanderson, and John Widdowson. Atlantic Highlands, NJ: Humanities Press, 1977.

all editions of Barnes's dialect poems in the modified form of the dialect (i.e. from the mid 1850s onwards) MacMahon, Michael K. C. "Phonology." Chapter 5 of The Cambridge History of the English Language, Vol. 4, $1776-$ 1997. Ed. Suzanne Romaine. Cambridge: Cambridge Univ. Press, 1998.

Middle English (roughly 1100 to 1500)

Old English (up to about 1100)

The Oxford English Dictionary Online

$<$ http://www.oed.com>

past participle 
proto-RP

$\mathrm{RP}$

$S D D$

SED

StE

SW

$\mathrm{V}$

$v$.

Wakelin

WBCP

WBPG

Wells

Widén
The nineteenth-century forerunner of RP

Received pronunciation

Studies on the Dorset Dialect (see Widén)

Orton, Harold, and Eugen Dieth. Survey of English Dialects. Leeds: E. J. Arnold for the University of Leeds. (A) Introduction by Harold Orton, 1962. (B) The Basic Material. Vol. 4, The Southern Counties, ed. Harold Orton and Martyn F. Wakelin, 1967-68.

Standard English

Southwest(ern)

Vowel

verb

Wakelin, Martyn F. The Southwest of England. Varieties of English around the World. Text Series 5. Gen. Ed. Manfred Görlach. Amsterdam: Benjamins, 1986.

The Complete Poems of William Barnes. Ed. T. L. Burton and K. K. Ruthven. 3 vols. Oxford: Clarendon Press. 2013-. William Barnes's Dialect Poems: A Pronunciation Guide. By T. L. Burton. Adelaide and Provo, UT: The Chaucer Studio Press, 2010.

Wells, J. C. Accents of English. 3 vols. Cambridge: Cambridge Univ. Press, 1982

Widén, Bertil. Studies on the Dorset Dialect. Lund Studies in English 16. Lund: Gleerup, 1949. Nendeln: Kraus, 1968. 



\section{KEY TO PHONETIC SYMBOLS}

Except where otherwise stated, words used in this key to illustrate the sounds are assumed to have the same pronunciation as in RP. Parentheses around a phonetic character indicate that it may be either sounded or silent; those around a length mark indicate that the preceding character may be either long or short. The symbols are a selection from amongst those offered by the International Phonetic Association, along lines similar to the usage in the Oxford English Dictionary, with some modifications.

\begin{tabular}{|c|c|c|}
\hline CONSONANTS & & \\
\hline $\mathrm{b}$ as in bin & $\mathrm{p}$ & as in pat \\
\hline as in $\operatorname{din}$ & $\mathrm{r}$ & as in rat \\
\hline $\mathrm{d}_{3}$ as in judge, gin & S & as in $\sin$ \\
\hline $\mathrm{f} \quad$ as in $f i n$ & $\int$ & as in shin \\
\hline as in get & $\mathrm{t}$ & as in tin \\
\hline as in hot & ts & as in $c h i n$ \\
\hline as in yet & $\theta$ & as in thin (voiceless th-) \\
\hline as in cat & ð & as in this (voiced th-) \\
\hline as in let & $\mathrm{v}$ & as in vat \\
\hline as in mat & $\mathrm{w}$ & as in win \\
\hline as in net & $\mathrm{z}$ & as in 200 \\
\hline as in sing & 3 & as in measure \\
\hline $\mathrm{yg}$ as in finger & & \\
\hline
\end{tabular}

\section{SHORT VOWELS}
a as in French madame
I as in pit
a as in GenAm hot
ə as in $\underline{a b o u t}$
$\mathrm{p}$ as in $p o t$
$\Lambda$ as in putt, cut
$\varepsilon$ as in pet
$\mathrm{U}$ as in put, foot
$\mathrm{i}$ as in French si
$\mathrm{u}$ as in French douce 
LONG VOWELS

$\begin{array}{ll}\text { a: as in German Tag or Australian } & \text { o: as in burn } \\ \text { carpark } & \text { o: as in born, dawn } \\ \text { E: as in German fährt } & \text { O: as in German Sohn } \\ \text { e: as in German Schnee } & \text { u: as in boon } \\ \text { i: as in bean } & \end{array}$

DiPHTHONGS AND GLIDES

æI as in Australian g'day, mate

jeə as in yair

iə as in fear

uə combines /u/ with /ə/

Eə as in fair

ว:I between buy and boy, with a

ja: as in German $j a, ~ J a b r$

long first element

je as in yet

je: as in German jäbrlich
o:u as in know, with a long first element

\section{ALTERNATIVE PRONUNCIATIONS}

As in StE, many common words may be pronounced in more than one way in Barnes's dialect. Wherever convenient, as with the final / $\mathrm{d} /$ of and, ground, etc., or the initial /h/ of when, where, etc., parentheses are used to show that a character may be either silent or sounded. Where this is not possible, as in the case of alternative vowel pronunciations, different readers may opt for different pronunciations, as may the same reader on different occasions. The commonest examples are collected in the table on the following page. The defining factor is often (but not necessarily) a matter of stress: column 2 shows the pronunciation that is most probable when the word is stressed; column 3 shows the pronunciation when it is unstressed or lightly stressed. In many instances readers may wish to substitute the alternative form for the form used in the transcripts of the poems in the main part of the book. 


\section{TABLE OF COMMON ALTERNATIVES}

The -es ending on plural nouns (when syllabic) may be either / Iz/ or / $\mathrm{oz} /$. The -est ending on superlative adjectives may be either /Ist/ or / əst/. The ending -ess in -ness, -less, etc. may be either /IS/ or /os/.

\begin{tabular}{|c|c|c|}
\hline Word & Stressed & Unstressed \\
\hline as & $\mathrm{az}$ & $\partial \mathrm{Z}$ \\
\hline at & at & ot \\
\hline but & $\mathrm{b} \Lambda \mathrm{t}$ & bət \\
\hline do & du: & də \\
\hline dost & $\mathrm{d}_{\Lambda} \mathrm{st}$ & dəst \\
\hline for $(v a r, v o r)$ & va:r & var, vər \\
\hline from & vrom & vrəm \\
\hline ha' ('have') & ha & hə \\
\hline he, 'e & (h)i: & ə \\
\hline must & $\mathrm{m} \Lambda \mathrm{s}(\mathrm{t})$ & $\operatorname{mos}(t)$ \\
\hline nor $($ nar, nor $)$ & nar & nar, nər \\
\hline or $(a r, o r)$ & a:r & ar, or \\
\hline so ('to that extent') & so: & So \\
\hline some & $\mathrm{s} \Lambda \mathrm{m}$ & səm \\
\hline than & ðan & ðən \\
\hline that & ðat & ðət \\
\hline the & $\begin{array}{l}\text { ði (before a } \\
\text { vowel) }\end{array}$ & $\begin{array}{l}\text { ðə (before a } \\
\text { consonant) }\end{array}$ \\
\hline their & ðعər, ðer & ðər \\
\hline there & ðعər, ðer & ðər \\
\hline to & $\operatorname{tu}(:)$ & to \\
\hline wher & (h)weər & (h)wər \\
\hline year & jərr, jiər & jiər \\
\hline you $(y o u, y a)$ & ju: & jə \\
\hline your & $\mathrm{ju}(\mathrm{s}) \partial \mathrm{r}$ & jər \\
\hline
\end{tabular}





\section{INTRODUCTION}

\section{The spelling and pronunciation of the modified form of the dialect}

When "The bit o' ground at huome" appeared in the Dorset County Chronicle on 11 September 1856, it was the first poem Barnes had published in DCC since “Jeän o' Grenley Mill” had appeared there on 14 September 1843thirteen years previously almost to the day; ${ }^{1}$ and it was twelve years since the publication in 1844 of Poems of Rural Life, in the Dorset Dialect: With a Dissertation and Glossary (containing almost all the dialect poems Barnes had published in DCC in the ten-year period from the beginning of 1834 to the end of 1843), which became, retrospectively, his first collection of poems in the Dorset dialect.

Readers with a long memory and an interest in language might have been surprised by some of the spellings they encountered in this new poem. Whereas some spellings would have been familiar from Barnes's previous poems (buome in the title, -in as the ending of the present participle in lines 2 and 3, da throughout for unemphatic auxiliary $d o, z$ for initial $s$ in zee and zummer in lines 5 and 6, rudges for ridges in 32, etc.), others would not. Amongst the unfamiliar spellings in the first half of the poem readers would have found peäce (which might be mistaken for peace but is intended for pace) in line 3 and pleäce (i.e. place) in line 4 instead of the earlier spellings piace and pliace; raïn (10), weïgh (20), and sträight (28) for earlier râin, wâigh, and strâight; eärbs (28) for earlier yarbs; and so on.

Nothing was said about these new spellings at that time, but when Barnes's second collection of poems in dialect came out in 1859, containing most of the poems he had published in DCC in the previous three years (including this one, retitled "John an' Thomas"), he made some further changes in spelling (such as the abandonment of $d a$ for unemphatic auxiliary do) and included a preface saying, "I have taken for this volume of Dorset Poems, a mode of spelling which I believe is more intelligible than that of the former one, inasmuch as it gives the lettered Dialect more of the bookform of the national speech, and yet is so marked as to preserve, as correctly as the other, the Dorset pronunciation." The claim about pronunciation is,

\footnotetext{
${ }^{1}$ The reasons for this break from publishing in DCC are discussed in the introduction to WBCP ii..
} 
however, immediately undercut by the sentence that follows, "Th in thatch, thick, thief, thimble, thin, thing, think, thong, thorn, thumb, represent the soft clipping th in thee"; that is to say, in the ten the words listed the initial consonant sound, which is voiceless in $\mathrm{StE}$ (as in thug and thanks), is voiced in the dialect (as in thee or they). This dialectal voicing had earlier been shown in the broad form of the dialect by italicizing the th and later by replacing it with the runic character $\delta$; but now, in the spelling of the modified form of the dialect, it is left entirely unmarked.

There were further changes in spelling in the second edition of the second collection (1863), and yet more (including the restoration of some broad forms that had earlier been abandoned) in the three-in-one collection of 1879, which became the standard edition of Barnes's dialect poems thereafter and from which the text in this book is taken. These individual changes do not concern us here, though I give below, in tabular form, a summary of the chief spellings used in the final version of the modified form of the dialect in 1879 , showing how they differ from the spellings of the broad form.

The question that does concern us here is the ways in which these differences in spelling affect the pronunciation of Barnes's dialect poems, if indeed they affect it at all. The safest way to find an answer to this question is to consult the various descriptions of Dorset pronunciation that Barnes gives in the grammars of the dialect that he published at different times in his career (the 1844 Dissertation, the 1863 Grammar, and the 1886 Glossary). If his description of a particular sound changes significantly in one of the later grammars, it may reasonably be assumed that the different description reflects a change of mind about the sound's pronunciation. We find, however, that although the wording of the description changes in the later grammars, its substance remains more or less the same throughout his life; thus corn is pronounced /ka:rn/, whether it is spelled with $o$ or with $a$ (1844 Diss. \25; 1863 Grammar, p. 13; 1886 Glossary, p. 4; WBPG 7.22.1); and father will be/fع:ðər/, whether the spelling is faether or fäther or father (1844 Diss. \23; 1863 Grammar, p. 13; 1886 Glossary, p. 4; WBPG 7.7.4). Sometimes, however, rhyme or rhythm call for a pronunciation other than the usual one. The combinations irl and $u r l$, for instance, are normally pronounced /ardəl/, with an intrusive /də/ separating the consonants and making the 
monosyllabic combination / arrl/ disyllabic (1844 Diss. §33; 1863 Grammar, p. 13; 1886 Glossary, p. 15; WBPG 8.8.4); but in a line such as "In whirls along the woody gleädes" in the first stanza of "Comèn hwome" in the third collection, the poem's consistently octosyllabic rhythm requires that whirls remain monosyllabic, hence /(h)wərlz/. In other cases again the rhythm demands elision of $/ \mathrm{d} ə /$ to $/ \mathrm{d} /$, as in "Waters, drough the meäds a-purlèn | ... An' smoke, above the town a-curlèn" in the fourth stanza of "Zun-zet" in the second collection. In such cases readers have the choice as to whether to include the $/ \mathrm{d} /$ without $/ \mathrm{o} /$ or to opt for the alternative pronunciation for url, /arrl/; the transcription is accordingly given as /arr(d)lən/.

\section{Chief differences in spelling between the broad form of the dialect in 1844 and the modified form in 1879}

The table below is arranged alphabetically according to the spellings found in column 2-the spellings used in the poems appearing in this book-with occasional alternative spellings in parentheses. These are the spellings of the modified form of the dialect preferred by Barnes in 1879, his last published book of poems, containing revised versions of all three of his collections of Poems of Rural Life in the Dorset Dialect brought together in one volume. ${ }^{2}$ The spellings are followed by the intended pronunciation and selected examples. Column 1 gives the equivalent spellings used in the broad form of the dialect in 1844; column 3 shows the equivalent spelling in StE, with the pronunciation in RP; and column 4 gives references to those parts of $W B P G$ (a summary of which may be found in the Appendix to this volume) where the suggested pronunciation in Barnes's day is explained. Where no additional examples are given (as for after and among), the word in bold is itself the example. Words that are spelled and pronounced as in RP are omitted.

No attempt is made to record in the table the various changes Barnes made in his spelling in the years from 1856 (when he first began publishing poems written in the modified form of the dialect) to 1879 (when he

\footnotetext{
${ }^{2}$ For a more detailed discussion of the differences in spelling and grammar between 1844 and 1879 see T. L. Burton, "What William Barnes Done: Dilution of the Dialect in Later Versions of the Poems Of Rural Life," Review of English Studies 58 (2007): 338-63.
} 
published his last book of poems in dialect). For a detailed account of some of the major changes involved see WBCP ii, Appendix 3.

\begin{tabular}{|c|c|c|c|}
\hline $\begin{array}{l}1844 \text { spelling, } \\
\text { pronunciation, } \& \\
\text { examples }\end{array}$ & $\begin{array}{l}1879 \text { spelling, } \\
\text { pronunciation, \& } \\
\text { examples }\end{array}$ & $\begin{array}{l}\text { StE spelling, RP } \\
\text { pronunciation, } \& \\
\text { examples }\end{array}$ & $\begin{array}{c}W B P G \\
\text { ref }\end{array}$ \\
\hline $\begin{array}{c}\text { a } \\
\text { /a/ } \\
\text { agg, bag, drashel, } \\
\text { lag, langth, stratch }\end{array}$ & $\begin{array}{c}\text { a } \\
\text { /a/ } \\
\text { agg, bag, drashel, } \\
\text { lag, langth, stratch }\end{array}$ & $\begin{array}{c}\mathbf{e} \\
/ \varepsilon / \\
\text { egg, beg, threshold, } \\
\text { leg, length, stretch }\end{array}$ & 7.2 .3 \\
\hline $\begin{array}{l}\text { abrode } \\
\text { /obro:d/ }\end{array}$ & $\begin{array}{c}\text { abrode, abroad } \\
\text { /obro:d/ }\end{array}$ & $\begin{array}{l}\text { abroad } \\
\text { /obro:d/ }\end{array}$ & 7.13 .7 \\
\hline $\begin{array}{c}\text { à'ter, āter } \\
\text { / \&:tər/ }\end{array}$ & $\begin{array}{l}\text { after } \\
\text { / }: \text { :tər/ }\end{array}$ & $\begin{array}{l}\text { after } \\
\text { /aifter/ }\end{array}$ & 7.7.4 \\
\hline $\begin{array}{c}\text { age } \\
\text { /ع:d3/ } \\
\text { cage, wages }\end{array}$ & $\begin{array}{c}\text { age } \\
\text { /ع:d3/ } \\
\text { cage, wages }\end{array}$ & $\begin{array}{c}\text { age } \\
\text { /eId3/ } \\
\text { cage, wages }\end{array}$ & 7.11 .13 \\
\hline $\begin{array}{l}\text { agen, agiën, again } \\
\text { /ogen/,/ogjen/ }\end{array}$ & $\begin{array}{l}\text { ageän } \\
\text { /ogjen/ }\end{array}$ & $\begin{array}{l}\text { again } \\
\text { /ogemn/,/ogen/ }\end{array}$ & 7.11 .4 \\
\hline $\begin{array}{l}\text { agoo } \\
\text { /ogu:/ }\end{array}$ & $\begin{array}{l}\text { agoo } \\
\text { /ogu:/ }\end{array}$ & $\begin{array}{l}\text { ago } \\
\text { /agav/ }\end{array}$ & 7.14.6 \\
\hline $\begin{array}{c}\text { âi } \\
\text { /æı/ } \\
\text { afrâid, hâil, mâid, } \\
\text { prâise, râin, strâight, } \\
\text { tâil, trâin, wâit }\end{array}$ & $\begin{array}{c}\text { aï } \\
\text { /æı/ } \\
\text { afraïd, haill, maïd, } \\
\text { praïse, raï, straïght, } \\
\text { tail, traïn, waït }\end{array}$ & $\begin{array}{c}\text { ai } \\
\text { /eI/ } \\
\text { afraid, hail, maid, } \\
\text { praise, rain, straight, } \\
\text { tail, train, wait }\end{array}$ & 7.11 .6 \\
\hline $\begin{array}{c}\text { âi } \\
\text { /æI/ } \\
\text { nâighbour, âight, } \\
\text { wâight, vâil }\end{array}$ & $\begin{array}{c}\text { aï } \\
\text { /æi/ } \\
\text { naïghbour, aïght, } \\
\text { waïght, vail }\end{array}$ & $\begin{array}{c}\text { ei } \\
\text { /eI/ } \\
\text { neighbour, eight, } \\
\text { weight, veil }\end{array}$ & 7.11 .6 \\
\hline $\begin{array}{l}\text { âir } \\
\text { /æarr/ }\end{array}$ & $\begin{array}{l}\text { aïr } \\
\text { /æIr } /\end{array}$ & $\begin{array}{l}\text { air } \\
/ \varepsilon \partial /\end{array}$ & $\begin{array}{l}7.20 .5 \\
8.8 .1\end{array}$ \\
\hline
\end{tabular}




\begin{tabular}{|c|c|c|c|}
\hline $\begin{array}{c}\text { afe, āfe, āf } \\
\text { / } \varepsilon: f / \\
\text { cafe, hafe, hāfe, lāf, } \\
\text { lāfe, lafe }\end{array}$ & $\begin{array}{c}\text { alf, augh } \\
\text { / E:f/ } \\
\text { calf, half, laugh }\end{array}$ & $\begin{array}{c}\text { alf, augh } \\
\text { /a:f/ } \\
\text { calf, half, laugh }\end{array}$ & 7.7.4 \\
\hline $\begin{array}{c}\text { āk(e), } \bar{a}^{\prime} \mathbf{k}(\mathbf{e}) \\
\text { / } \mathrm{k} \mathrm{k} /, / \mathrm{a}: \mathrm{k} / \\
\text { chāk, stā'k, tā'k(e), } \\
\text { ta'k(e), wā'k(e), } \\
\text { wa'k(e) }\end{array}$ & $\begin{array}{c}\text { alk } \\
/ \text { \&:k/ } \\
\text { chalk, stalk, talk, } \\
\text { walk }\end{array}$ & $\begin{array}{c}\text { alk } \\
\text { /o:k/ } \\
\text { chalk, stalk, talk, } \\
\text { walk }\end{array}$ & 7.13 .2 \\
\hline $\begin{array}{c}\text { al, al', âl, āl, all, āll } \\
\text { /a:l/, / ع:l/ } \\
\text { al, al', āl, cal, call, } \\
\text { cāll, val, vall, vāl, } \\
\text { hal, hall, smal, small, } \\
\text { smāl, squal, sqâll, } \\
\text { squāl }\end{array}$ & $\begin{array}{c}\text { all } \\
\text { /a:l/ } \\
\text { all, call, fall, hall, } \\
\text { small, squall }\end{array}$ & $\begin{array}{c}\text { all } \\
\text { /o:1/ } \\
\text { all, call, fall, hall, } \\
\text { small, squall }\end{array}$ & 7.13 .1 \\
\hline $\begin{array}{c}\text { always, ālwiz } \\
\text { /a:lwe:z/,/E:lwı/ }\end{array}$ & $\begin{array}{l}\text { always } \\
\text { /a:lwe:z/ }\end{array}$ & $\begin{array}{l}\text { always } \\
\text { /o:lweız/ }\end{array}$ & 7.11 .8 \\
\hline $\begin{array}{l}\text { among } \\
\text { /ampy/ }\end{array}$ & $\begin{array}{l}\text { among } \\
\text { /ampy/ }\end{array}$ & $\begin{array}{l}\text { among } \\
/ \mathrm{\partial m} \wedge \mathrm{y} /\end{array}$ & 7.8 .3 \\
\hline $\begin{array}{c}\text { ānce, āns } \\
\text { /E:ns/ } \\
\text { dānce, glānce, } \\
\text { ānswer }\end{array}$ & $\begin{array}{c}\text { ance, ans } \\
\text { / E:ns/ } \\
\text { dance, glance, } \\
\text { answer }\end{array}$ & $\begin{array}{c}\text { ance, ans } \\
\text { /a:ns/ } \\
\text { dance, glance, } \\
\text { answer }\end{array}$ & 7.7.4 \\
\hline $\begin{array}{c}\text { annge } \\
\text { /and3/ } \\
\text { anngel, channge, } \\
\text { dannger, strannge(r) }\end{array}$ & $\begin{array}{c}\text { ange } \\
\text { /and3/ } \\
\text { angel, change, } \\
\text { danger, strange(r) }\end{array}$ & $\begin{array}{c}\text { ange } \\
\text { /eind3/ } \\
\text { angel, change, } \\
\text { danger, strange(r) }\end{array}$ & 7.11.12 \\
\hline $\begin{array}{c}\text { ar } \\
\text { /a:r/ } \\
\text { warm, swarm, } \\
\text { toward }\end{array}$ & $\begin{array}{c}\text { ar } \\
\text { /a:r/ } \\
\text { warm, swarm, } \\
\text { toward }\end{array}$ & $\begin{array}{c}\text { ar } \\
/ \mathrm{o} / / \\
\text { warm, swarm, } \\
\text { toward }\end{array}$ & $\begin{array}{c}7.22 .2 \\
8.8 .1\end{array}$ \\
\hline
\end{tabular}




\begin{tabular}{|c|c|c|c|}
\hline $\begin{array}{c}\text { ar } \\
\text { /arr } / \\
\text { larn, sar, sarve, } \\
\text { sarch }\end{array}$ & $\begin{array}{c}\text { ar, ear } \\
\text { /arr/ } \\
\text { larn, learn, sar, } \\
\text { sarve, sarch }\end{array}$ & $\begin{array}{c}\text { er, ear } \\
\text { /ə: } / \\
\text { learn, serve, search }\end{array}$ & $\begin{array}{l}7.9 .2 \\
8.8 .1\end{array}$ \\
\hline $\begin{array}{c}\text { ar, ear } \\
\text { /arr/ } \\
\text { cart, dark, farm, } \\
\text { harm, heart }\end{array}$ & $\begin{array}{c}\text { ar, ear } \\
\text { /arr/ } \\
\text { cart, dark, farm, } \\
\text { harm, heart }\end{array}$ & $\begin{array}{c}\text { ar, ear } \\
\text { /a:/ } \\
\text { cart, dark, farm, } \\
\text { harm, heart }\end{array}$ & $\begin{array}{c}7.21 .1 \\
8.8 .1\end{array}$ \\
\hline $\begin{array}{c}\text { are, ear } \\
\text { / } \varepsilon \text { or } / \\
\text { square, ware, bear, } \\
\text { wear }\end{array}$ & $\begin{array}{c}\text { are, ear } \\
\text { / cər } / \\
\text { square, ware, bear, } \\
\text { wear }\end{array}$ & $\begin{array}{c}\text { are, ear } \\
\text { /عə/ } \\
\text { square, ware, bear, } \\
\text { wear }\end{array}$ & $\begin{array}{c}7.20 .1 \\
8.8 .1\end{array}$ \\
\hline $\begin{array}{c}\text { ass } \\
\text { /ais } / \\
\text { brass, glass, grass, } \\
\text { pass }\end{array}$ & $\begin{array}{c}\text { ass } \\
\text { /ars } / \\
\text { brass, glass, grass, } \\
\text { pass }\end{array}$ & $\begin{array}{c}\text { ass } \\
\text { /ais } / \\
\text { brass, glass, grass, } \\
\text { pass }\end{array}$ & 7.7.1 \\
\hline $\begin{array}{c}\text { ass } \\
/ \mathrm{a}(\mathrm{:}) \mathrm{s} / \\
\text { ass, lass, cassen }\end{array}$ & $\begin{array}{c}\text { ass } \\
/ \mathrm{a}(:) \mathrm{s} / \\
\text { ass, lass, cassen }\end{array}$ & $\begin{array}{c}\text { ass } \\
/ æ s / \\
\text { ass, lass, canst not }\end{array}$ & 7.7 .2 \\
\hline $\begin{array}{c}\text { āth, aeth } \\
/ \varepsilon: ð /, / \varepsilon: \theta / \\
\text { fāther, faether, pāth }\end{array}$ & $\begin{array}{c}\text { ath } \\
/ \varepsilon: \partial /, / \varepsilon: \theta / \\
\text { father, path }\end{array}$ & $\begin{array}{l}\text { ath } \\
\text { /a:ð/, /a: } \theta / \\
\text { father, path }\end{array}$ & 7.7 .4 \\
\hline $\begin{array}{l}\text { athirt } \\
\text { /əðə:rt/ }\end{array}$ & $\begin{array}{l}\text { ath irt } \\
\text { /əðə:rt/ }\end{array}$ & $\begin{array}{l}\text { athwart } \\
\text { / } \theta \theta w o: t /\end{array}$ & $\begin{array}{c}8.16 .2 \\
8.8 .1\end{array}$ \\
\hline $\begin{array}{c}\text { al, a’1, āl } \\
\text { /a:l/, / ع:l/ } \\
\text { bal, crâl, hal, hāl, } \\
\text { ma'l, spra'l, sprāl }\end{array}$ & $\begin{array}{c}\text { aul, awl } \\
\text { /o:l/ } \\
\text { bawl, crawl, haul } \\
\text { (hawl), mawl, sprawl }\end{array}$ & $\begin{array}{c}\text { aul, awl } \\
\text { /o:l/ } \\
\text { bawl, crawl, haul, } \\
\text { maul, sprawl }\end{array}$ & 7.13 .1 \\
\hline $\begin{array}{c}\text { ān, āen } \\
\text { / Eın/ } \\
\text { flānt, hānt(e), } \\
\text { sānter, māen }\end{array}$ & $\begin{array}{c}\text { aun, awn, an } \\
\text { / E:n/ } \\
\text { flant, haunt, saunter, } \\
\text { mawn }\end{array}$ & $\begin{array}{c}\text { aun, awn } \\
\text { /o:n/ } \\
\text { flaunt, haunt, } \\
\text { saunter, mawn } \\
\text { ('basket') }\end{array}$ & 7.13 .3 \\
\hline
\end{tabular}




\begin{tabular}{|c|c|c|c|}
\hline $\begin{array}{c}\text { ānt, an’t } \\
\text { /ع:nt / } \\
\text { ānt, cānt, can't, slānt }\end{array}$ & $\begin{array}{l}\text { aunt, ant, an't } \\
\quad \text { / ع:nt/ } \\
\text { aunt, can't, slant }\end{array}$ & $\begin{array}{l}\text { aunt, ant, an't } \\
\quad \text { /a:nt/ } \\
\text { aunt, can't, slant }\end{array}$ & 7.7.4 \\
\hline $\begin{array}{c}\text { avore } \\
\text { /ovuor/,/ovo:r/ }\end{array}$ & $\begin{array}{c}\text { avore } \\
\text { /ovuər/, /ovo:r/ }\end{array}$ & $\begin{array}{l}\text { afore } \\
\text { /ofo:/ }\end{array}$ & $\begin{array}{l}7.23 .4 \\
8.8 .1\end{array}$ \\
\hline $\begin{array}{l}\text { awoy } \\
\text { / } \text { owว:I/ }\end{array}$ & 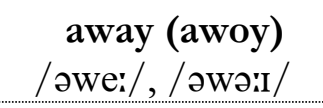 & $\begin{array}{l}\text { away } \\
\text { /oweI/ }\end{array}$ & 7.11 .8 \\
\hline $\begin{array}{c}\text { ax } \\
\text { /a:ks/ }\end{array}$ & $\begin{array}{c}\text { ax } \\
\text { /a:ks/ }\end{array}$ & $\begin{array}{l}\text { ask } \\
\text { /a:sk/ }\end{array}$ & 8.9 .2 \\
\hline $\begin{array}{c}\text { ây } \\
\text { /æi/ } \\
\text { bây, gây, hây, mây, } \\
\text { pây, plây, prây(er), } \\
\text { sprây, stây, swây }\end{array}$ & 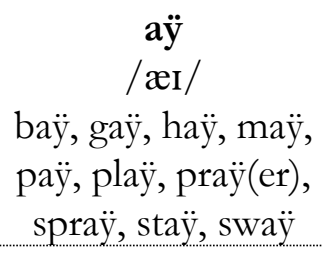 & $\begin{array}{c}\text { ay } \\
\text { /eI/ } \\
\text { bay, gay, hay, may, } \\
\text { pay, play, pray(er), } \\
\text { spray, stay, sway }\end{array}$ & 7.11 .6 \\
\hline $\begin{array}{c}\text { à, a, āe, ae, æ, è } \\
\text { /e:/ } \\
\text { clāa , lāe, lae, zā, zae, } \\
\text { grēe (in grēgole } \\
\text { 'bluebell'), whē }\end{array}$ & $\begin{array}{c}\text { ay, ey } \\
\text { /e:/ } \\
\text { clay, lay, zay, grey } \\
\text { (gray), whey }\end{array}$ & $\begin{array}{c}\text { ay, ey } \\
\text { /eI/ } \\
\text { clay, lay, say, grey, } \\
\text { whey }\end{array}$ & 7.11 .7 \\
\hline $\begin{array}{c}\text { beät } \\
\text { /biət/,/bjet/ }\end{array}$ & $\begin{array}{c}\text { beät } \\
/ \text { biot/,/bjet/ }\end{array}$ & $\begin{array}{l}\text { beat } \\
\text { /bitt/ }\end{array}$ & 7.11 .3 \\
\hline $\begin{array}{c}\text { bekiaze, bekiase } \\
\text { /bikje:z/ }\end{array}$ & $\begin{array}{l}\text { because } \\
\text { /bikje:z/ }\end{array}$ & $\begin{array}{l}\text { because } \\
\text { /bikbz/ }\end{array}$ & 7.13 .4 \\
\hline $\begin{array}{c}\text { bin, ben } \\
/ \text { bin/, /ben/ }\end{array}$ & $\begin{array}{l}\text { been (ben) } \\
/ \text { bin/,/ben/ }\end{array}$ & $\begin{array}{l}\text { been } \\
\text { /bi:n/ }\end{array}$ & 7.10 .1 \\
\hline $\begin{array}{l}\text { bewar } \\
\text { /biwa:r/ }\end{array}$ & $\begin{array}{l}\text { bewar } \\
\text { /biwa:r/ }\end{array}$ & $\begin{array}{l}\text { beware } \\
\text { /brweə/ }\end{array}$ & $\begin{array}{l}7.20 .7 \\
8.8 .1\end{array}$ \\
\hline $\begin{array}{c}\text { beyand, beyond } \\
\text { /bijand/ }\end{array}$ & $\begin{array}{c}\text { beyond (beyand) } \\
\text { /bijand } /\end{array}$ & $\begin{array}{l}\text { beyond } \\
\text { /bijpnd/ }\end{array}$ & 7.4 \\
\hline $\begin{array}{l}\text { blather } \\
\text { /blaðər/ }\end{array}$ & $\begin{array}{l}\text { blath er } \\
\text { /bladər/ }\end{array}$ & $\begin{array}{l}\text { bladder } \\
\text { /blædər/ }\end{array}$ & $\begin{array}{l}8.2 .3 \\
8.8 .1\end{array}$ \\
\hline $\begin{array}{l}\text { bote, bo'te } \\
\text { /bo:t/ }\end{array}$ & $\begin{array}{c}\text { bought } \\
\text { /bo:t/,/bo:t/ }\end{array}$ & $\begin{array}{l}\text { bought } \\
\text { /bo:t/ }\end{array}$ & $7.13 .8 \mathrm{~b}$ \\
\hline
\end{tabular}




\begin{tabular}{|c|c|c|c|}
\hline $\begin{array}{c}\text { brēak, brē'k, break } \\
\text { /bre:k/, /brjek/ }\end{array}$ & $\begin{array}{l}\text { break } \\
\text { /bre:k/ }\end{array}$ & $\begin{array}{l}\text { break } \\
\text { /bresk/ }\end{array}$ & 7.11 .11 \\
\hline $\begin{array}{l}\text { brudge } \\
\text { /brıd3/ }\end{array}$ & $\begin{array}{c}\text { bridge (brudge) } \\
\text { /brıd } 3 /\end{array}$ & $\begin{array}{l}\text { bridge } \\
\text { /brid3/ }\end{array}$ & 7.1.4a \\
\hline $\begin{array}{l}\text { brode } \\
\text { /bro:d/ }\end{array}$ & $\begin{array}{l}\text { broad, brode } \\
\text { /bro:d/ }\end{array}$ & $\begin{array}{l}\text { broad } \\
\text { /bro:d/ }\end{array}$ & 7.13 .7 \\
\hline $\begin{array}{l}\text { brote, brōte, } \\
\text { brought } \\
\text { /bro:t/,/bro:t/ }\end{array}$ & $\begin{array}{l}\text { brought (brote) } \\
\text { /bro:t/, /bro:t/ }\end{array}$ & $\begin{array}{l}\text { brought } \\
\text { /bro:t/ }\end{array}$ & $7.13 .8 \mathrm{~b}$ \\
\hline $\begin{array}{l}\text { buoy } \\
\text { /bwəiI/ }\end{array}$ & $\begin{array}{l}\text { bwoy } \\
\text { /bwə:I/ }\end{array}$ & $\begin{array}{l}\text { boy } \\
\text { /boi/ }\end{array}$ & 7.17 .4 \\
\hline $\begin{array}{l}\text { cage } \\
/ \mathrm{k} \varepsilon: \mathrm{d} 3 /\end{array}$ & $\begin{array}{l}\text { cage } \\
/ \mathrm{k} \varepsilon: \mathrm{d} 3 /\end{array}$ & $\begin{array}{l}\text { cage } \\
\text { / keId3/ }\end{array}$ & 7.11 .13 \\
\hline $\begin{array}{l}\text { car } \\
\text { /ka:r/ }\end{array}$ & $\begin{array}{l}\text { car } \\
\text { /karr/ }\end{array}$ & $\begin{array}{l}\text { carry } \\
/ \text { kæri/ }\end{array}$ & 7.3.4 \\
\hline $\begin{array}{l}\text { kiard } \\
\text { /kja:rd/ }\end{array}$ & $\begin{array}{l}\text { ceärd } \\
\text { /kja:rd/ }\end{array}$ & $\begin{array}{l}\text { card } \\
\text { /ka:d/ }\end{array}$ & $\begin{array}{l}7.21 .2 \\
8.8 .1\end{array}$ \\
\hline $\begin{array}{l}\text { chammer } \\
\text { /tfamor/ }\end{array}$ & $\begin{array}{l}\text { chammer } \\
\text { /tfamor/ }\end{array}$ & $\begin{array}{l}\text { chamber } \\
/ \mathrm{t} \text { Sermbo/ }\end{array}$ & 7.11 .12 \\
\hline $\begin{array}{l}\text { cheäk } \\
\text { /tfiok/ }\end{array}$ & $\begin{array}{l}\text { cheäk } \\
\text { /t fïk/ }\end{array}$ & $\begin{array}{l}\text { cheek } \\
/ \mathrm{tgik} /\end{array}$ & 7.10 .13 \\
\hline $\begin{array}{l}\text { cheem } \\
\text { /t fi:m/ }\end{array}$ & $\begin{array}{l}\text { cheem } \\
\text { /t fi:m/ }\end{array}$ & $\begin{array}{l}\text { chime } \\
\text { /t } \mathrm{tam} /\end{array}$ & 7.10 .2 \\
\hline 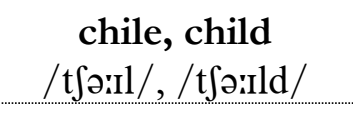 & 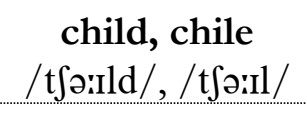 & $\begin{array}{l}\text { child } \\
\text { /t } \text { tarld/ }\end{array}$ & 7.16 .4 \\
\hline $\begin{array}{l}\text { clavy } \\
\text { /klavi/ }\end{array}$ & $\begin{array}{l}\text { clavy } \\
\text { /klavi/ }\end{array}$ & $\begin{array}{l}\text { clavel } \\
\text { /klævəl/ }\end{array}$ & 7.3.4 \\
\hline $\begin{array}{l}\text { clim, clim' } \\
\text { /klim/ }\end{array}$ & $\begin{array}{c}\text { clim' (climb) } \\
\text { / klim/ }\end{array}$ & $\begin{array}{l}\text { climb } \\
\text { /klaim/ }\end{array}$ & 7.16 .4 \\
\hline $\begin{array}{c}\operatorname{clum}(p p l .) \\
/ \mathrm{kl} \Lambda \mathrm{m} /\end{array}$ & $\begin{array}{l}\text { clom }(p p l .) \\
/ \mathrm{kl} \Lambda \mathrm{m} /\end{array}$ & $\begin{array}{l}\text { climbed } \\
\text { / klaimd/ }\end{array}$ & 7.16 .10 \\
\hline
\end{tabular}




\begin{tabular}{|c|c|c|c|}
\hline $\begin{array}{c}\text { clomb (past tense) } \\
/ \mathrm{kl} \Lambda \mathrm{m} /\end{array}$ & $\begin{array}{c}\text { clomb (past tense) } \\
/ \mathrm{kl} \Lambda \mathrm{m} /\end{array}$ & $\begin{array}{l}\text { climbed } \\
\text { /klaimd/ }\end{array}$ & 7.16 .10 \\
\hline $\begin{array}{c}\text { cloas, cloaz } \\
\text { /klo:z/ }\end{array}$ & $\begin{array}{l}\text { clothes } \\
\text { /klo:z/ }\end{array}$ & $\begin{array}{l}\text { clothes } \\
\text { /klouðz/ }\end{array}$ & 8.13 .3 \\
\hline $\begin{array}{l}\text { coose } \\
\text { /kuis/ }\end{array}$ & $\begin{array}{l}\text { coo'se } \\
\text { /kuis/ }\end{array}$ & $\begin{array}{l}\text { course } \\
/ \mathrm{ko} \text { :s } /\end{array}$ & $7.23 .6 \mathrm{~b}$ \\
\hline $\begin{array}{l}\text { curdle } \\
\text { /kə:rdəl/ }\end{array}$ & $\begin{array}{c}\text { curl } \\
\text { /kə:rdəl/, / kə:rl/ }\end{array}$ & $\begin{array}{l}\text { curl } \\
\text { / kə:l/ }\end{array}$ & $\begin{array}{l}8.8 .4 \\
8.8 .1\end{array}$ \\
\hline $\begin{array}{c}\text { daeter, dāter, } \\
\text { dā'ter } \\
\text { /de:tər/ }\end{array}$ & $\begin{array}{c}\text { daughter (dā'ter) } \\
\text { /de:tər/ }\end{array}$ & $\begin{array}{l}\text { daughter } \\
\text { /dortə/ }\end{array}$ & $\begin{array}{l}7.13 .5 \\
8.8 .1\end{array}$ \\
\hline $\begin{array}{c}\text { dā, dae, dāe, da', } \\
\text { dây } \\
/ \text { de: } /, / \text { dæi } /\end{array}$ & $\begin{array}{c}\text { day (daÿ) } \\
\text { /de:/ }\end{array}$ & $\begin{array}{l}\text { day } \\
\text { /deI/ }\end{array}$ & 7.11 .7 \\
\hline $\begin{array}{c}\text { da (unstressed) } \\
/ \text { do/ }\end{array}$ & $\begin{array}{c}\text { do (unstressed) } \\
\text { /do/ }\end{array}$ & $\begin{array}{l}\text { do } \\
\text { /du:/ }\end{array}$ & 7.15 .5 \\
\hline $\begin{array}{l}\text { dont, don't } \\
\text { /do:nt/ }\end{array}$ & $\begin{array}{c}\text { don't (dont) } \\
\text { /do:nt/ }\end{array}$ & $\begin{array}{l}\text { don't } \\
\text { /dount/ }\end{array}$ & 7.14 .14 \\
\hline $\begin{array}{c}\text { door } \\
\text { /duər/, ?/dəruər/ }\end{array}$ & $\begin{array}{c}\text { door } \\
\text { /duər/,?/dəruər/ }\end{array}$ & $\begin{array}{l}\text { door } \\
\text { /do:/ }\end{array}$ & $\begin{array}{c}7.23 .2 \\
8.8 .1 \\
\end{array}$ \\
\hline $\begin{array}{c}\mathbf{d r} \text { (initial) } \\
/ \mathrm{dr} / \\
\text { drash, drashel, } \\
\text { dreat, dree, droat, } \\
\text { droo, drow, drush }\end{array}$ & $\begin{array}{c}\text { dr (initial) } \\
/ \text { dr/ } \\
\text { drash, drashel, } \\
\text { dreat, dree, droat, } \\
\text { droo, drow, drush }\end{array}$ & $\begin{array}{l}\text { thr (initial) } \\
/ \text { Or/ } \\
\text { thrash, threshold, } \\
\text { threat, three, throat, } \\
\text { through, throw, } \\
\text { thrush }\end{array}$ & 8.14 \\
\hline $\begin{array}{l}\text { drēve } \\
\text { /dre:v/ }\end{array}$ & $\begin{array}{c}\text { dreve (drēve) } \\
\text { /dre:v/ }\end{array}$ & $\begin{array}{l}\text { drive } \\
\text { /draiv/ }\end{array}$ & 7.10 .6 \\
\hline $\begin{array}{c}\text { e } \\
/ \varepsilon / \\
\text { peck, het, spet, ef }\end{array}$ & $\begin{array}{c}\mathbf{e} \\
/ \varepsilon / \\
\text { peck, het, spet }\end{array}$ & $\begin{array}{c}\mathbf{i} \\
/ \mathrm{I} / \\
\text { pick, hit, spit, if }\end{array}$ & 7.1.4b \\
\hline
\end{tabular}




\begin{tabular}{|c|c|c|c|}
\hline $\begin{array}{c}\text { èa, è } \\
\text { /e:/, /i: } / \\
\text { dēal, drēm, ēat, } \\
\text { rēach, strēam }\end{array}$ & $\begin{array}{c}\text { ea } \\
\text { /i:/, /e:/ } \\
\text { deal, dream, eat, } \\
\text { reach, stream }\end{array}$ & $\begin{array}{c}\text { ea } \\
\text { /i:/ } \\
\text { deal, dream, eat, } \\
\text { reach, stream }\end{array}$ & 7.10 .4 \\
\hline $\begin{array}{c}\text { ya (initial) } \\
/ \mathbf{j} \varepsilon / \\
\text { yable, yacre, yache, } \\
\text { yal(e), yapern }\end{array}$ & $\begin{array}{c}\text { eä (initial) } \\
/ \text { je/ } \\
\text { eäble, eäcre, eäche, } \\
\text { eäle, eäpern, eäpron }\end{array}$ & $\begin{array}{c}\text { a (initial) } \\
\text { /eI/ } \\
\text { able, acre, ache, ale, } \\
\text { apron }\end{array}$ & 7.11 .5 \\
\hline $\begin{array}{c}\text { eä (medial) } \\
\text { /iə/ } \\
\text { beän, feäst, leäd, } \\
\text { leäve, meäd }\end{array}$ & $\begin{array}{c}\text { eä (medial) } \\
\text { /iə/ } \\
\text { beän, feäst, leäd, } \\
\text { leäve, meäd }\end{array}$ & $\begin{array}{c}\text { ea (medial) } \\
\text { /i:/ } \\
\text { bean, feast, lead, } \\
\text { leave, mead }\end{array}$ & $\begin{array}{l}7.10 .8 \\
7.11 .2\end{array}$ \\
\hline $\begin{array}{c}\mathbf{i a}+\mathbf{C}+\mathbf{e}, \mathbf{i a}+\mathbf{C}+\mathbf{y} \\
\quad / \mathbf{j} \varepsilon / \\
\text { biake, griace, griave, } \\
\text { liady, miake, niame, } \\
\text { shiade, shiape, siake, } \\
\text { siame, riace }\end{array}$ & $\begin{array}{c}\text { eä+C+e, eä+C+y } \\
\text { /je/ } \\
\text { beäke, greäce, } \\
\text { greäve, leädy, } \\
\text { meäke, neäme, } \\
\text { sheäde, sheäpe, } \\
\text { seäke, seäme, reäce }\end{array}$ & $\begin{array}{c}\text { a+C+e, a+C+y } \\
\text { /ei/ } \\
\text { bake, grace, grave, } \\
\text { lady, make name, } \\
\text { shade, shape, sake, } \\
\text { same, race }\end{array}$ & 7.11.1-2 \\
\hline $\begin{array}{c}\text { iair, iare } \\
\text { /jeər/ } \\
\text { fiair, hiair, piair, } \\
\text { diairy, viairy, } \\
\text { biare, bliare, miare, } \\
\text { shiare }\end{array}$ & $\begin{array}{c}\text { eäir, eäre } \\
\text { /jعər/ } \\
\text { feäir, heäir, peäir, } \\
\text { deäiry, veäiry, } \\
\text { beäre, bleäre, meäre, } \\
\text { sheäre }\end{array}$ & $\begin{array}{c}\text { air, are } \\
\text { / } \text { cə/ }^{2} \\
\text { fair, hair, pair, dairy, } \\
\text { fairy, } \\
\text { bare, blare, mare, } \\
\text { share }\end{array}$ & $\begin{array}{l}7.20 .2 \\
8.8 .1\end{array}$ \\
\hline $\begin{array}{c}\text { ear, yer (final or } \\
\text { medial) } \\
\text { /iər/,/jər/ }\end{array}$ & $\begin{array}{c}\text { ear (final or medial) } \\
\text { /iər/ }\end{array}$ & $\begin{array}{c}\text { ear (final or medial) } \\
\text { /ı / }\end{array}$ & $\begin{array}{l}7.19 .3 \\
8.5 .5 \\
8.8 .1\end{array}$ \\
\hline $\begin{array}{c}\text { yar (initial) } \\
\text { /ja:r/ } \\
\text { yarn, yarnest, yarbs }\end{array}$ & $\begin{array}{c}\text { eär (initial) } \\
\text { /ja:r/ } \\
\text { eärn, eärnest, eärbs }\end{array}$ & $\begin{array}{l}\text { ear, (h)er (initial) } \\
\text { /orr/ } \\
\text { earn, earnest, herbs }\end{array}$ & 7.9 .3 \\
\hline $\begin{array}{c}\text { yer, ear (word) } \\
\text { /jərr/, /iər/ }\end{array}$ & $\begin{array}{l}\text { ear (word) } \\
\text { /jərr/, /iər/ }\end{array}$ & $\begin{array}{c}\text { ear (word) } \\
\text { /ı / }\end{array}$ & $\begin{array}{l}7.19 .3 \\
8.5 .5 \\
8.8 .1\end{array}$ \\
\hline
\end{tabular}




\begin{tabular}{|c|c|c|c|}
\hline $\begin{array}{c}\text { ear, eer, ere } \\
\text { /iər/ } \\
\text { clear, dear, hear, } \\
\text { near, beer, cheer, } \\
\text { here }\end{array}$ & $\begin{array}{c}\text { ear, eer, ere } \\
\text { /iər/ } \\
\text { clear, dear, hear, } \\
\text { near, beer, cheer, } \\
\text { here }\end{array}$ & $\begin{array}{c}\text { ear, eer, ere } \\
\text { /ıə/ } \\
\text { clear, dear, hear, } \\
\text { near, beer, cheer, } \\
\text { here }\end{array}$ & $\begin{array}{l}7.19 .1 \\
8.8 .1\end{array}$ \\
\hline $\begin{array}{c}\text { yarm } \\
\text { /ja:rm/ }\end{array}$ & $\begin{array}{l}\text { eärm } \\
\text { / ja:rm/ }\end{array}$ & $\begin{array}{l}\text { arm } \\
\text { /a:m/ }\end{array}$ & $\begin{array}{l}7.21 .6 \\
8.8 .1\end{array}$ \\
\hline $\begin{array}{c}\text { i, ee } \\
/ \mathrm{I} /, / \mathrm{i}(\mathrm{i}) / \\
\text { kip, mit, sim, swit, } \\
\text { wik } \\
\text { keep, meet, seem, } \\
\text { sweet, week }\end{array}$ & $\begin{array}{c}\text { ee } \\
/ \mathrm{I} /, / \mathrm{i}(\mathrm{i}) / \\
\text { keep, meet, seem, } \\
\text { sweet, week }\end{array}$ & $\begin{array}{c}\text { ee } \\
\text { /i:/ } \\
\text { keep, meet, seem, } \\
\text { sweet, week }\end{array}$ & 7.10 .11 \\
\hline $\begin{array}{l}\text { elem } \\
\text { /Eləm/ }\end{array}$ & $\begin{array}{l}\text { elem } \\
\text { / } \text { cləm/ }\end{array}$ & $\begin{array}{l}\mathrm{elm} \\
/ \mathrm{elm} /\end{array}$ & 8.6 \\
\hline $\begin{array}{l}\text { èn, en (final) } \\
\text { /ən/ } \\
\text { buildèn, doèn, } \\
\text { veedèn, zettèn, } \\
\text { zingèn, marnen, } \\
\text { woaken }\end{array}$ & $\begin{array}{l}\text { èn, en (final) } \\
\text { /on/ } \\
\text { buildèn, doèn, } \\
\text { veedèn, zettèn, } \\
\text { zingèn, mornèn, } \\
\text { woaken }\end{array}$ & $\begin{array}{c}\text { ing, en (final) } \\
\text { /In/, /on/ } \\
\text { building, doing, } \\
\text { feeding, setting, } \\
\text { singing, morning, } \\
\text { oaken }\end{array}$ & $\begin{array}{l}7.1 .5 \\
8.4 .3\end{array}$ \\
\hline $\begin{array}{c}\text { er+C } \\
\text { /orr/ } \\
\text { herd, kern }\end{array}$ & $\begin{array}{c}\text { er+C } \\
\text { /arr/ } \\
\text { herd, kern }\end{array}$ & $\begin{array}{c}\text { er+C } \\
\text { /ə:/ } \\
\text { herd, kern }\end{array}$ & $\begin{array}{l}7.9 .1 \\
8.8 .1\end{array}$ \\
\hline $\begin{array}{c}\text { eth } \\
/ \varepsilon \theta / \\
\text { eth, beth, meth }\end{array}$ & $\begin{array}{c}\text { e'th } \\
/ \varepsilon \theta / \\
\text { eth, beth, meth }\end{array}$ & $\begin{array}{c}\text { earth, irth } \\
\text { /ə:t/ } \\
\text { earth, birth, mirth }\end{array}$ & $\begin{array}{l}7.9 .5 \mathrm{~d} \\
8.8 .5\end{array}$ \\
\hline $\begin{array}{l}\text { evemen } \\
\text { /i:vmən/ }\end{array}$ & $\begin{array}{l}\text { evenèn } \\
\text { /i:vmən/ }\end{array}$ & $\begin{array}{l}\text { evening } \\
\text { /i:vnin/ }\end{array}$ & 8.7 .1 \\
\hline $\begin{array}{l}\text { fakket } \\
\text { /fakot/ }\end{array}$ & $\begin{array}{l}\text { faggot (fakket) } \\
\text { /fagot/,/fakət/ }\end{array}$ & $\begin{array}{l}\text { faggot } \\
\text { / fægat/ }\end{array}$ & 8.4 .2 \\
\hline $\begin{array}{l}\text { food } \\
\text { /fud/ }\end{array}$ & $\begin{array}{l}\text { food } \\
\text { /fud/ }\end{array}$ & $\begin{array}{l}\text { food } \\
\text { / fu:d/ }\end{array}$ & 7.6.2 \\
\hline
\end{tabular}




\begin{tabular}{|c|c|c|c|}
\hline $\begin{array}{c}\text { foüght, föwght } \\
\text { /forut/ }\end{array}$ & $\begin{array}{l}\text { foüght } \\
\text { / farut/ }\end{array}$ & $\begin{array}{l}\text { fought } \\
\text { /fo:t/ }\end{array}$ & 7.13.8c \\
\hline $\begin{array}{l}\text { ghiame } \\
\text { /gjem/ }\end{array}$ & $\begin{array}{l}\text { geäme } \\
\text { /gjem/ }\end{array}$ & $\begin{array}{l}\text { game } \\
\text { /germ/ }\end{array}$ & 8.4 .1 \\
\hline $\begin{array}{l}\text { giarden, ghiarden } \\
\text { /gja:rdən/, } \\
\text { /giordən/ }\end{array}$ & $\begin{array}{l}\text { geärden } \\
\text { /gjairdən/ }\end{array}$ & $\begin{array}{l}\text { garden } \\
\text { /ga:dən/ }\end{array}$ & $\begin{array}{l}7.21 .2-3 \\
8.4 .1 \\
8.8 .1\end{array}$ \\
\hline $\begin{array}{l}\text { geät(e), ghiate } \\
\text { /giat/,/gjet/ }\end{array}$ & $\begin{array}{l}\text { geäte (geät) } \\
\text { /giat/,/gjet/ }\end{array}$ & $\begin{array}{l}\text { gate } \\
\text { /geit/ }\end{array}$ & $\begin{array}{l}7.11 .3 \\
8.4 .1\end{array}$ \\
\hline $\begin{array}{l}\text { gi'e } \\
\text { /gi:/ }\end{array}$ & $\begin{array}{l}\text { gi'e } \\
\text { /gii/ }\end{array}$ & $\begin{array}{l}\text { give } \\
\text { /giv/ }\end{array}$ & $\begin{array}{l}7.1 .8 \\
8.15 .1\end{array}$ \\
\hline $\begin{array}{l}\text { gilcup, gil'cup } \\
\text { /gilkıp/ }\end{array}$ & $\begin{array}{c}\text { gil'cup (gilcup) } \\
\text { /gilk^p/ }\end{array}$ & $\begin{array}{l}\text { gilt-cup } \\
\text { /giltkıp/ }\end{array}$ & 8.4 .4 \\
\hline $\begin{array}{l}\text { girt } \\
\text { /gart/ }\end{array}$ & $\begin{array}{l}\text { girt } \\
\text { /gə:rt/ }\end{array}$ & $\begin{array}{l}\text { great } \\
\text { /greit/ }\end{array}$ & $\begin{array}{c}7.9 .4 \\
7.11 .11 \\
8.8 .3\end{array}$ \\
\hline $\begin{array}{l}\text { gnot } \\
\text { /nat/ }\end{array}$ & $\begin{array}{c}\text { gnot (gnat) } \\
\text { /nat } /\end{array}$ & $\begin{array}{l}\text { gnat } \\
\text { /næt/ }\end{array}$ & 7.3.2 \\
\hline $\begin{array}{l}\text { goo, go } \\
\text { /gu: } /\end{array}$ & $\begin{array}{c}\text { goo (go) } \\
\text { /gu:/ (/go:/) }\end{array}$ & $\begin{array}{l}\text { go } \\
\text { /gəu/ }\end{array}$ & 7.14.6 \\
\hline $\begin{array}{l}\text { gookoo } \\
\text { /guku:/ }\end{array}$ & $\begin{array}{c}\text { goocoo, gookoo } \\
\text { /guku: }\end{array}$ & $\begin{array}{l}\text { cuckoo } \\
\text { /kuku:/ }\end{array}$ & 8.1 \\
\hline $\begin{array}{l}\text { goold } \\
\text { /guild/ }\end{array}$ & $\begin{array}{l}\text { goold } \\
\text { /guild/ }\end{array}$ & $\begin{array}{l}\text { gold } \\
\text { /gould/ }\end{array}$ & 7.14 .5 \\
\hline $\begin{array}{l}\text { gramfer } \\
\text { /gramfor/ }\end{array}$ & $\begin{array}{l}\text { gramfer } \\
\text { /gramfor/ }\end{array}$ & $\begin{array}{l}\text { grandfather } \\
\text { /græn(d)fa:ðə/ }\end{array}$ & 8.13 .2 \\
\hline $\begin{array}{l}\text { grammer } \\
\text { /gramər/ }\end{array}$ & $\begin{array}{l}\text { grammer } \\
\text { /gramər/ }\end{array}$ & $\begin{array}{l}\text { grandmother } \\
\text { /græn(d)m } \iota_{\partial ə /}\end{array}$ & 8.13 .2 \\
\hline $\begin{array}{l}\text { Grange } \\
\text { /gre:nd3/ }\end{array}$ & $\begin{array}{l}\text { Grange } \\
\text { /gre:nd3/ }\end{array}$ & $\begin{array}{l}\text { Grange } \\
\text { /greind3/ }\end{array}$ & 7.11.12 \\
\hline $\begin{array}{l}\text { gwâin } \\
\text { /gwæın/ }\end{array}$ & $\begin{array}{l}\text { gwaïn } \\
\text { /gwæin/ }\end{array}$ & $\begin{array}{l}\text { going } \\
\text { /gouin/ }\end{array}$ & 7.14 .7 \\
\hline
\end{tabular}




\begin{tabular}{|c|c|c|c|}
\hline $\begin{array}{l}\text { ha' } \\
\text { /ha/ }\end{array}$ & $\begin{array}{l}\text { ha' } \\
\text { /ha/ }\end{array}$ & $\begin{array}{c}\text { has, have } \\
/ \text { hæz/,/hæv/ }\end{array}$ & 8.15 .1 \\
\hline $\begin{array}{l}\text { 'e (unstressed) } \\
/ \mathrm{\partial} /, / \mathrm{i}(\mathrm{i}) /\end{array}$ & $\begin{array}{l}\text { he (unstressed) } \\
/ \mathrm{o} /, / \mathrm{i}(\mathrm{i}) /, / \mathrm{hi} /\end{array}$ & $\begin{array}{l}\text { he } \\
\text { /hi:/ }\end{array}$ & 7.10 .1 \\
\hline $\begin{array}{l}\text { hear } \\
\text { /hior/ }\end{array}$ & $\begin{array}{c}\text { hear (heär) } \\
\text { /hior/ }\end{array}$ & $\begin{array}{l}\text { hear } \\
\text { /hiə/ }\end{array}$ & $\begin{array}{c}7.19 .3 \\
8.5 .5 \\
8.8 .1\end{array}$ \\
\hline $\begin{array}{l}\text { heärd } \\
\text { /hiərd/ }\end{array}$ & $\begin{array}{c}\text { heärd } \\
\text { /hiərd/, /hjərrd/ }\end{array}$ & $\begin{array}{l}\text { heard } \\
\text { /hə:d/ }\end{array}$ & $\begin{array}{c}7.9 .6 \\
7.19 .4 \\
8.5 .5 \\
8.8 .1\end{array}$ \\
\hline $\begin{array}{l}\text { here } \\
\text { /hior/ }\end{array}$ & $\begin{array}{l}\text { here } \\
\text { /hior/ }\end{array}$ & $\begin{array}{l}\text { here } \\
\text { /hiə/ }\end{array}$ & $\begin{array}{c}7.19 .3 \\
8.5 .5 \\
8.8 .1\end{array}$ \\
\hline $\begin{array}{l}\text { het } \\
\text { /het/ }\end{array}$ & $\begin{array}{l}\text { het } \\
\text { /het/ }\end{array}$ & $\begin{array}{l}\text { heat } \\
\text { /hit: / }\end{array}$ & 7.10 .10 \\
\hline $\begin{array}{l}\text { heth } \\
/ \text { he } \theta /\end{array}$ & $\begin{array}{l}\text { he'th } \\
/ \text { he } \theta /\end{array}$ & $\begin{array}{l}\text { hearth } \\
\text { /ha: } \theta /\end{array}$ & 7.21 .4 \\
\hline $\begin{array}{l}\text { hoss } \\
\text { /hps/ }\end{array}$ & $\begin{array}{l}\text { ho'se hoss } \\
\text { /hps/ }\end{array}$ & $\begin{array}{l}\text { horse } \\
\text { /ho:s/ }\end{array}$ & $\begin{array}{c}7.8 .4 \\
7.22 .4 \\
8.8 .5\end{array}$ \\
\hline $\begin{array}{l}\text { hovel } \\
\text { /h^val/ }\end{array}$ & $\begin{array}{l}\text { hovel } \\
\text { /h^val/ }\end{array}$ & $\begin{array}{c}\text { hovel } \\
/ \mathrm{hpval} /, / \mathrm{h} \Lambda \mathrm{v} \mathrm{l} /\end{array}$ & 7.4 .2 \\
\hline $\begin{array}{c}\overline{\mathbf{1}}, \mathbf{i}+\mathbf{C}+\mathbf{e}, \mathbf{i g h} \text { (etc.: } \\
\text { long } i \text { ) } \\
\text { / əII } / \\
\text { drìth, ice, eye, } \\
\text { height, light, smile, } \\
\text { try, vind }\end{array}$ & $\begin{array}{c}\mathbf{i}+\mathbf{C}+\mathbf{e}, \text { igh }(\text { etc.: } \\
\text { long } i) \\
\text { / III/ } \\
\text { drith, ice, eye, } \\
\text { height, light, smile, } \\
\text { try, vind }\end{array}$ & $\begin{array}{c}\text { i+C+e, igh (etc.: } \\
\text { long } i \text { ) } \\
\text { /ai/ } \\
\text { dryness, ice, eye, } \\
\text { height, light, smile, } \\
\text { try, find }\end{array}$ & $\begin{array}{c}7.16 \\
7.16 .1\end{array}$ \\
\hline $\begin{array}{l}\text { idden } \\
\text { /Idən/ }\end{array}$ & $\begin{array}{l}\text { idden } \\
\text { /Idən/ }\end{array}$ & $\begin{array}{l}\text { isn't } \\
\text { / Izənt / }\end{array}$ & 8.9 .3 \\
\hline
\end{tabular}




\begin{tabular}{|c|c|c|c|}
\hline $\begin{array}{c}\text { ir+C } \\
\text { / orr / } \\
\text { bird, dirt, shirt, stir }\end{array}$ & $\begin{array}{c}\text { ir+C } \\
\text { / orr / } \\
\text { bird, dirt, shirt, stir }\end{array}$ & $\begin{array}{c}\text { ir+C } \\
\text { /ə:/ } \\
\text { bird, dirt, shirt, stir }\end{array}$ & $\begin{array}{l}7.9 .1 \\
8.8 .1\end{array}$ \\
\hline $\begin{array}{c}\text { ire, ier } \\
\text { / ə:Iər/ } \\
\text { vire, vier, squire, tire }\end{array}$ & $\begin{array}{c}\text { ire, ier } \\
\text { /ə:ır/ } \\
\text { vire, vier, squire, tire }\end{array}$ & $\begin{array}{c}\text { ire } \\
\text { /aiə/ } \\
\text { fire, squire, tire }\end{array}$ & $\begin{array}{l}7.16 .2 \\
8.8 .1\end{array}$ \\
\hline $\begin{array}{l}\text { 'ithin, within } \\
\text { /(w)IðIn/ }\end{array}$ & $\begin{array}{c}\text { 'ithin, within } \\
\text { /(w)IðIn/ }\end{array}$ & $\begin{array}{l}\text { within } \\
\text { /wıðIn/ }\end{array}$ & 8.16 .1 \\
\hline $\begin{array}{c}\text { 'ithout, without } \\
\text { /(w)ıðə:ut/ }\end{array}$ & $\begin{array}{c}\text { 'ithout, without } \\
\text { /(w)ıð:ut/ }\end{array}$ & $\begin{array}{l}\text { without } \\
\text { /wiðaut/ }\end{array}$ & 8.16 .1 \\
\hline $\begin{array}{c}\text { jây } \\
\text { /dzæi/ }\end{array}$ & $\begin{array}{c}\text { jaÿ } \\
\text { /dzæi/ }\end{array}$ & $\begin{array}{l}\text { joy } \\
\text { /dzoI/ }\end{array}$ & 7.17 .3 \\
\hline $\begin{array}{c}\text { jis', jist, just } \\
\text { /dzIs/, /dzIst/, } \\
\text { /d } 3 \Lambda \text { st } /\end{array}$ & $\begin{array}{c}\text { jist, just (jis', jus') } \\
/ \mathrm{d}_{3} \mathrm{Ist} /, / \mathrm{d}_{3} \Lambda \mathrm{st} / \\
/ \mathrm{d}_{3} \mathrm{IS} /, / \mathrm{d}_{3} \Lambda \mathrm{S} /\end{array}$ & $\begin{array}{c}\text { just } \\
/ \mathrm{d} 3 \wedge \mathrm{st} /\end{array}$ & 7.5.6 \\
\hline $\begin{array}{c}\text { Jahn, John } \\
/ \text { dzan } /\end{array}$ & $\begin{array}{c}\text { John (Jahn) } \\
/ \text { dzan } /\end{array}$ & $\begin{array}{l}\text { John } \\
\text { /dzpn/ }\end{array}$ & 7.4 \\
\hline $\begin{array}{l}\text { laid } \\
/ 1 \varepsilon \mathrm{d} /\end{array}$ & $\begin{array}{l}\text { laid } \\
/ 1 \varepsilon d /\end{array}$ & $\begin{array}{l}\text { laid } \\
\text { /leId/ }\end{array}$ & 7.11 .7 \\
\hline $\begin{array}{c}\text { lāste, laste, lēste } \\
\text { /le:st/ }\end{array}$ & $\begin{array}{l}\text { laste } \\
\text { /lesst/ }\end{array}$ & $\begin{array}{l}\text { last } \\
\text { /la:st/ }\end{array}$ & 7.7.4 \\
\hline $\begin{array}{l}\text { lather } \\
\text { /laðər/ }\end{array}$ & $\begin{array}{l}\text { lather } \\
\text { /laðər/ }\end{array}$ & $\begin{array}{l}\text { ladder } \\
\text { /lædər/ }\end{array}$ & $\begin{array}{l}8.2 .3 \\
8.8 .1\end{array}$ \\
\hline $\begin{array}{c}\text { lik' (adv., past tense) } \\
/ \mathrm{lik} /\end{array}$ & $\begin{array}{c}\text { lik', like (adv., past } \\
\text { tense) } \\
/ 1 \mathrm{lk} /\end{array}$ & $\begin{array}{l}\text { like } \\
\text { /lark/ }\end{array}$ & 7.16 .5 \\
\hline $\begin{array}{l}\text { lo'k, look } \\
\text { /luk/ }\end{array}$ & $\begin{array}{c}\text { look, (lo'k) } \\
\text { /luk/ }\end{array}$ & $\begin{array}{l}\text { look } \\
\text { /luk/ }\end{array}$ & 7.6.5 \\
\hline $\begin{array}{c}\text { meäd } \\
/ \mathrm{miəd} /, / \mathrm{mi} \mathrm{d} / \text {, } \\
/ \mathrm{mj \varepsilon d} /\end{array}$ & $\begin{array}{c}\text { meäd } \\
/ \mathrm{miəd} /, / \mathrm{mi}: \mathrm{d} / \text {, } \\
/ \mathrm{mj \varepsilon d} /\end{array}$ & $\begin{array}{l}\text { mead } \\
/ \mathrm{mi}: \mathrm{d} /\end{array}$ & 7.11 .3 \\
\hline
\end{tabular}




\begin{tabular}{|c|c|c|c|}
\hline $\begin{array}{l}\text { miaster } \\
\text { /mjaistər/ }\end{array}$ & $\begin{array}{l}\text { meäster } \\
\text { /mjaistər/ }\end{array}$ & $\begin{array}{l}\text { master } \\
\text { /maistə/ }\end{array}$ & $\begin{array}{l}7.7 .3 \\
8.8 .1\end{array}$ \\
\hline $\begin{array}{c}\min (\text { 'mate') } \\
/ \text { min/ }\end{array}$ & $\begin{array}{c}\min (\text { 'mate') } \\
/ \text { min/ }\end{array}$ & & 7.1.6 \\
\hline $\begin{array}{c}\text { moot ('tree-stump') } \\
\text { /mut/ }\end{array}$ & $\begin{array}{c}\operatorname{moot}(\text { 'tree-stump') } \\
\text { /mut/ }\end{array}$ & $\begin{array}{c}\text { moot ('tree-stump') } \\
\text { /mu:t }\end{array}$ & 7.6.2 \\
\hline $\begin{array}{c}\text { moorn } \\
/ \text { mo:rn/,/muorn/ }\end{array}$ & $\begin{array}{c}\text { murn } \\
\text { /mo:rn/ }\end{array}$ & $\begin{array}{l}\text { mourn } \\
/ \mathrm{mo:n} /\end{array}$ & $\begin{array}{c}7.9 .7 \\
7.23 .5\end{array}$ \\
\hline $\begin{array}{l}\text { nâise } \\
\text { /næız/ }\end{array}$ & $\begin{array}{l}\text { naïse } \\
\text { /næiz/ }\end{array}$ & $\begin{array}{l}\text { noise } \\
\text { /norz/ }\end{array}$ & 7.17 .2 \\
\hline $\begin{array}{c}\text { noo ('not any') } \\
\text { /nu:/ }\end{array}$ & $\begin{array}{c}\text { noo ('not any') } \\
\text { /nu:/ }\end{array}$ & $\begin{array}{c}\text { no } \\
/ \text { nəo/ }\end{array}$ & 7.14 .6 \\
\hline $\begin{array}{c}\text { nuone } \\
/ \text { nusn/,/nuən/ }\end{array}$ & $\begin{array}{c}\text { nwone } \\
\text { /nusn/,/nuon/ }\end{array}$ & $\begin{array}{l}\text { none } \\
/ \mathrm{n} \wedge \mathrm{n} /\end{array}$ & 7.5.8 \\
\hline $\begin{array}{l}\mathbf{o}^{\prime} \\
/ \mathrm{O} /\end{array}$ & $\begin{array}{l}\mathbf{o}^{\prime} \\
/ \mathrm{O} /\end{array}$ & $\begin{array}{c}\text { of } \\
/ \mathrm{pv} /, / \mathrm{ov} /\end{array}$ & 8.3 .2 \\
\hline $\begin{array}{c}\text { a, o } \\
\text { /a/ } \\
\text { drap, Jahn, John, } \\
\text { beyand, beyond, } \\
\text { yander }\end{array}$ & $\begin{array}{c}\mathbf{0 , a} \\
/ \mathrm{a} /, / \mathrm{p} / \\
\text { drop (drap), John } \\
\text { (Jahn), beyond } \\
\text { (beyand), yonder } \\
\text { (yander) }\end{array}$ & $\begin{array}{c}\mathbf{o} \\
/ \mathrm{p} / \\
\text { drop, John, beyond, } \\
\text { yonder }\end{array}$ & 7.4 \\
\hline $\begin{array}{c}\text { o, oa, o+C+e } \\
\text { /o:/ } \\
\text { broke, coal, hole, } \\
\text { poll, stole, voke, } \\
\text { vo'ke }\end{array}$ & $\begin{array}{c}\text { o, oa, o+C+e } \\
\text { /o:/ } \\
\text { broke, coal, hole, } \\
\text { poll, stole, vo'ke }\end{array}$ & $\begin{array}{c}\text { o, oa, o+C+e } \\
\text { /ov/ } \\
\text { broke, coal, hole, } \\
\text { poll, stole, folk }\end{array}$ & 7.14.1-2 \\
\hline $\begin{array}{c}\overline{\mathbf{o}}^{\prime} \mathbf{m}, \overline{\mathbf{o}} \mathbf{\prime}, \overline{\mathbf{o}} \mathbf{s}, \overline{\mathbf{o}} \mathbf{t} \\
\text { /o:m/, /o:n/, /o:s/, } \\
\text { /o:t/ }\end{array}$ & $\begin{array}{c}\text { o'm, o'n, o's, o't } \\
\text { (o'm, o'n, o's, o's't) } \\
\text { /o:m/, /o:n/, /o:s/, } \\
\text { /o:t }\end{array}$ & $\begin{array}{c}\text { of 'em, of 'im, of } \\
\text { us, of it } \\
\text { /pv əm/,/pv Im/, } \\
/ \text { pv əs/,/pv it/ }\end{array}$ & 8.3 .3 \\
\hline $\begin{array}{l}\text { oben } \\
\text { /o:bən/ }\end{array}$ & $\begin{array}{l}\text { oben, open } \\
\text { /o:bən/, /o:pən/ }\end{array}$ & $\begin{array}{l}\text { open } \\
\text { /oupon/ }\end{array}$ & 8.7 .3 \\
\hline
\end{tabular}




\begin{tabular}{|c|c|c|c|}
\hline $\begin{array}{c}\operatorname{ar} \text { (final) } \\
\text { /a:r/, /ar/, /or/ } \\
\text { ar, var, nar }\end{array}$ & $\begin{array}{l}\text { or (final) } \\
\text { /arr/, /ar/, /or/ } \\
\text { or, vor (for), nor }\end{array}$ & $\begin{array}{c}\text { or (final) } \\
/ \text { : /, /ə/ } \\
\text { or, for, nor }\end{array}$ & $\begin{array}{c}7.22 .3 \\
8.8 .1\end{array}$ \\
\hline $\begin{array}{c}\text { ar (medial) } \\
\text { /arr/ } \\
\text { carn, fark, lard, } \\
\text { marnen, archet, } \\
\text { shart, starm }\end{array}$ & $\begin{array}{c}\text { or (medial) } \\
\text { /arr } \\
\text { corn, fork, lord, } \\
\text { mornèn, orcha'd, } \\
\text { short, storm }\end{array}$ & $\begin{array}{c}\text { or (medial) } \\
\text { /o: } / \\
\text { corn, fork, lord, } \\
\text { morning, orchard, } \\
\text { short, storm }\end{array}$ & $\begin{array}{c}7.22 .1 \\
8.8 .1\end{array}$ \\
\hline $\begin{array}{c}\text { or+C } \\
\text { / } \text { :r } / \\
\text { word, work, worthy }\end{array}$ & $\begin{array}{c}\text { or+C } \\
\text { / } \text { :rr } / \\
\text { word, work, worthy }\end{array}$ & $\begin{array}{c}\text { or+C } \\
\text { /ə:/ } \\
\text { word, work, worthy }\end{array}$ & $\begin{array}{l}7.9 .1 \\
8.8 .1\end{array}$ \\
\hline $\begin{array}{l}\text { archet } \\
\text { /arrteət/ }\end{array}$ & $\begin{array}{l}\text { orcha'd } \\
\text { /arrtfot/ }\end{array}$ & $\begin{array}{l}\text { orchard } \\
/ \text { ott } \partial \mathrm{d} /\end{array}$ & $\begin{array}{l}7.22 .1 \\
8.2 .4 \\
8.8 .7\end{array}$ \\
\hline $\begin{array}{c}\text { ore, uore, our } \\
\text { /uər/ } \\
\text { bevore, bore, } \\
\text { m(u)ore, court }\end{array}$ & $\begin{array}{c}\text { ore, uore, our } \\
\text { /uor/ } \\
\text { bevore, bore, } \\
\text { mwore, fourth }\end{array}$ & $\begin{array}{c}\text { or, ore, our } \\
\text { /or/ } \\
\text { before, bore, more, } \\
\text { court, fourth }\end{array}$ & $\begin{array}{c}7.23 .1 \\
8.8 .1\end{array}$ \\
\hline $\begin{array}{c}\text { ou, ow } \\
\text { / o:u/ } \\
\text { bough, cloud, } \\
\text { groun', house, out, } \\
\text { cow, how, now, } \\
\text { down }\end{array}$ & $\begin{array}{c}\text { ou, ow } \\
\text { / əu' } / \\
\text { bough, cloud, } \\
\text { groun(d), house, } \\
\text { out, cow, how, now, } \\
\text { down }\end{array}$ & $\begin{array}{c}\text { ou, ow } \\
\text { /au/ } \\
\text { bough, cloud, } \\
\text { ground, house, out, } \\
\text { cow, how, now, } \\
\text { down }\end{array}$ & 7.18 .1 \\
\hline $\begin{array}{l}\text { our, ower, ow'r } \\
\text { / ə:uər/ } \\
\text { our, hour, flower, } \\
\text { flow'r, shower, } \\
\text { show'r, tower }\end{array}$ & $\begin{array}{c}\text { our, ower, ow'r } \\
\text { / ə:uər/ } \\
\text { our, hour, flower, } \\
\text { flow'r, shower, } \\
\text { show'r, tower, tow'r }\end{array}$ & $\begin{array}{c}\text { our, ower } \\
\text { /auə/ } \\
\text { our, hour, flower, } \\
\text { shower, tower }\end{array}$ & $\begin{array}{c}7.18 .2 \\
8.8 .1\end{array}$ \\
\hline $\begin{array}{c}\text { oust, ust } \\
\text { /o:ust/, / } \mathrm{st} / \\
\text { crust, doust, dust }\end{array}$ & $\begin{array}{c}\text { oust (ust) } \\
\text { / ə:ust/, / } \Lambda \mathrm{st} / \\
\text { crust, doust, dust }\end{array}$ & $\begin{array}{c}\text { ust } \\
/ \Lambda \mathrm{st} / \\
\text { crust, dust }\end{array}$ & 7.5 .5 \\
\hline $\begin{array}{c}\text { out } \\
\text { / ə:ut/ } \\
\text { rout, strout, astrout }\end{array}$ & $\begin{array}{c}\text { out } \\
\text { /o:ut/ } \\
\text { rout, strout, a-strout }\end{array}$ & $\begin{array}{c}\text { ut } \\
/ \Lambda \mathrm{t} / \\
\text { rut, strut, a-strut }\end{array}$ & 7.5 .4 \\
\hline
\end{tabular}




\begin{tabular}{|c|c|c|c|}
\hline 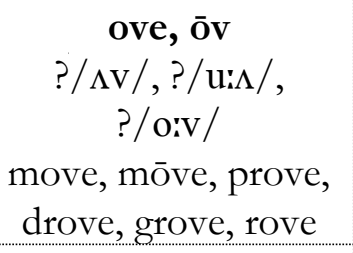 & 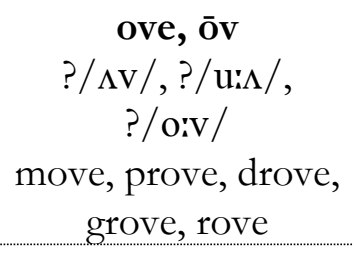 & $\begin{array}{c}\text { ove } \\
\text { /ui } /, / \text { /ou } \Lambda / \\
\text { move, prove, drove, } \\
\text { grove, rove }\end{array}$ & 7.5.3 \\
\hline $\begin{array}{l}\text { auver } \\
\text { /oivor/ }\end{array}$ & $\begin{array}{l}\text { over } \\
\text { /oivər/ }\end{array}$ & $\begin{array}{l}\text { over } \\
\text { /ouva/ }\end{array}$ & $\begin{array}{c}7.14 .10 \\
8.8 .1\end{array}$ \\
\hline $\begin{array}{l}\text { er (final, unstressed) } \\
\text { /o(r)/ } \\
\text { feller, holler, shaller, } \\
\text { winder, yaller, } \\
\text { yoller, zwaller }\end{array}$ & $\begin{array}{c}\text { ow (final, unstressed) } \\
\text { /ə(r)/ } \\
\text { fellow, hollow, } \\
\text { shallow, window, } \\
\text { yellow, yollow, } \\
\text { zwallow }\end{array}$ & $\begin{array}{c}\text { ow (final, unstressed) } \\
\text { /ou/ } \\
\text { fellow, hollow, } \\
\text { shallow, window, } \\
\text { yellow, swallow }\end{array}$ & $\begin{array}{c}7.14 .8 \\
8.8 .2\end{array}$ \\
\hline $\begin{array}{l}\text { pank } \\
\text { /pank/ }\end{array}$ & $\begin{array}{c}\text { pank (pant) } \\
/ \text { pank/ }\end{array}$ & $\begin{array}{l}\text { pant } \\
\text { /pænt/ }\end{array}$ & 8.12 .2 \\
\hline $\begin{array}{l}\text { parrick } \\
\text { /parik/ }\end{array}$ & $\begin{array}{c}\text { parrock (parrick) } \\
\text { /parik/ }\end{array}$ & $\begin{array}{l}\text { paddock } \\
\text { /pædək/ }\end{array}$ & 8.2 .1 \\
\hline $\begin{array}{l}\text { piart } \\
\text { /pjart/ }\end{array}$ & $\begin{array}{l}\text { peärt } \\
\text { /pja:rt/ }\end{array}$ & $\begin{array}{l}\text { part } \\
\text { /pa:t/ }\end{array}$ & $\begin{array}{l}7.21 .2 \\
8.8 .1\end{array}$ \\
\hline $\begin{array}{l}\text { poor } \\
/ \mathrm{pu}(:) \partial r /\end{array}$ & $\begin{array}{c}\text { poor } \\
/ \mathrm{pu}(\mathrm{i}) \partial \mathrm{r} /\end{array}$ & $\begin{array}{c}\text { poor } \\
/ \text { po:/,/puo/ }\end{array}$ & $\begin{array}{c}7.24 .1 \\
8.8 .1 \\
\end{array}$ \\
\hline $\begin{array}{l}\text { pirty } \\
\text { /pərti/ }\end{array}$ & $\begin{array}{c}\text { pretty, perty } \\
\text { (pirty) } \\
\text { /porti/ }\end{array}$ & $\begin{array}{l}\text { pretty } \\
\text { /priti/ }\end{array}$ & $\begin{array}{l}7.9 .4 \\
8.8 .3\end{array}$ \\
\hline $\begin{array}{l}\text { pwison } \\
\text { /pwə:Izən/ }\end{array}$ & $\begin{array}{l}\text { pweison } \\
\text { (pwoison) } \\
\text { /pwə:Izən/ }\end{array}$ & $\begin{array}{l}\text { poison } \\
\text { /porzon/ }\end{array}$ & $\begin{array}{l}7.17 .1 \\
8.16 .3\end{array}$ \\
\hline $\begin{array}{c}\text { quâits } \\
/ \mathrm{k}(\mathrm{w}) æ i t s /\end{array}$ & $\begin{array}{c}\text { quaïts } \\
/ \mathrm{k}(\mathrm{w}) æ i t s /\end{array}$ & $\begin{array}{l}\text { quoits } \\
/ \mathrm{k}(\mathrm{w}) \text { orts / }\end{array}$ & 7.17 .2 \\
\hline $\begin{array}{l}\text { quarrel } \\
\text { /kwarəl/ }\end{array}$ & $\begin{array}{c}\text { quarrel } \\
\text { /kwarel/,/kwarel/ }\end{array}$ & $\begin{array}{l}\text { quarrel } \\
\text { / kwbrol/ }\end{array}$ & 7.22 .5 \\
\hline
\end{tabular}




\begin{tabular}{|c|c|c|c|}
\hline $\begin{array}{c}\mathbf{r} \\
/ \mathrm{r} / \text { (always } \\
\text { sounded) }\end{array}$ & $\begin{array}{c}\mathbf{r} \\
/ \mathbf{r} /(\text { always } \\
\text { sounded) }\end{array}$ & $\begin{array}{c}\mathbf{r} \\
/ \mathrm{r} / \text { (mute before a } \\
\text { consonant or at the } \\
\text { end of a word) }\end{array}$ & 8.8.1 \\
\hline $\begin{array}{l}\text { rear } \\
\text { /reər/ }\end{array}$ & $\begin{array}{l}\text { rear } \\
/ \text { reər/ }\end{array}$ & $\begin{array}{l}\text { rear } \\
\text { /rio/ }\end{array}$ & $\begin{array}{l}7.19 .5 \\
8.8 .1\end{array}$ \\
\hline $\begin{array}{l}\text { rejâice } \\
\text { /ridzæis/ }\end{array}$ & $\begin{array}{l}\text { rejaïce } \\
\text { /ridzæis/ }\end{array}$ & $\begin{array}{l}\text { rejoice } \\
\text { /ridzoIs/ }\end{array}$ & 7.17.2 \\
\hline $\begin{array}{l}\text { rudge } \\
/ \mathrm{r} \wedge \mathrm{d} 3 /\end{array}$ & $\begin{array}{c}\text { ridge (rudge) } \\
/ \mathrm{r} \wedge \mathrm{d}_{3} /\end{array}$ & $\begin{array}{l}\text { ridge } \\
\text { /rid3/ }\end{array}$ & $7.1 .4 \mathrm{a}$ \\
\hline $\begin{array}{c}\text { rdle } \\
\text { /[ə:]rdəl/ } \\
\text { curdle, twirdle, } \\
\text { whirdle }\end{array}$ & 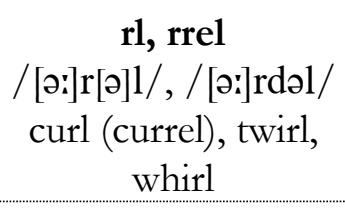 & $\begin{array}{c}\mathbf{r l} \\
/[ə:] 1 / \\
\text { curl, twirl, whirl }\end{array}$ & 8.8 .4 \\
\hline $\begin{array}{l}\text { ruf } \\
/ \mathrm{r} \wedge \mathrm{f} /\end{array}$ & $\begin{array}{l}\text { ruf (roof) } \\
/ / \mathrm{r} \wedge \mathrm{f} /\end{array}$ & $\begin{array}{l}\text { roof } \\
\text { /ruif/ }\end{array}$ & 7.5.2 \\
\hline $\begin{array}{l}\text { sass } \\
\text { / sa:s/ }\end{array}$ & $\begin{array}{l}\text { sa's, sauce } \\
\text { /sa:s/ }\end{array}$ & $\begin{array}{l}\text { sauce } \\
\text { /so:s/ }\end{array}$ & 7.13 .3 \\
\hline $\begin{array}{l}\text { sar } \\
\text { /sair/ }\end{array}$ & $\begin{array}{l}\text { sar } \\
\text { /sa:r/ }\end{array}$ & $\begin{array}{l}\text { serve } \\
\text { /so:v/ }\end{array}$ & $\begin{array}{l}7.9 .2 \\
8.15 .1\end{array}$ \\
\hline $\begin{array}{l}\text { sheen } \\
/ \text { /i:n/ }\end{array}$ & $\begin{array}{l}\text { sheen } \\
/ \text { /iin/ }\end{array}$ & $\begin{array}{l}\text { shine } \\
\text { / Sain/ }\end{array}$ & 7.10 .2 \\
\hline $\begin{array}{c}\text { shoot } \\
\text { /Sut/,/Suit/ }\end{array}$ & $\begin{array}{c}\text { shoot } \\
\text { /Sut/,/Suit/ }\end{array}$ & $\begin{array}{l}\text { shoot } \\
\text { / Suit/ }\end{array}$ & 7.6.3 \\
\hline $\begin{array}{l}\text { Shodon } \\
\text { /Spdən/ }\end{array}$ & $\begin{array}{c}\text { Shroton (Sho'ton) } \\
\text { /Spdən/ }\end{array}$ & $\begin{array}{l}\text { Shroton } \\
\text { / Srotən/ }\end{array}$ & 8.11 \\
\hline $\begin{array}{l}\text { sich, such } \\
/ \text { sit } / \text { /, /s } \Delta t 5 /\end{array}$ & $\begin{array}{l}\text { sich, such } \\
/ \text { sit } \int /, / \text { s } \Delta t S /\end{array}$ & $\begin{array}{l}\text { such } \\
/ \text { s } \Delta t S /\end{array}$ & 7.5.6 \\
\hline $\begin{array}{l}\text { skia'ce } \\
\text { /skjes/ }\end{array}$ & $\begin{array}{l}\text { skeä'ce } \\
\text { /skjєs/ }\end{array}$ & $\begin{array}{l}\text { scarce } \\
\text { /skeəs/ }\end{array}$ & $\begin{array}{c}7.20 .4 \\
8.8 .5\end{array}$ \\
\hline
\end{tabular}




\begin{tabular}{|c|c|c|c|}
\hline $\begin{array}{l}\text { sloo } \\
\text { /slu:/ }\end{array}$ & $\begin{array}{l}\text { sloo } \\
\text { /slu:/ }\end{array}$ & $\begin{array}{l}\text { sloe } \\
\text { /slou/ }\end{array}$ & 7.14 .6 \\
\hline $\begin{array}{l}\text { sloth } \\
/ \sin \theta /\end{array}$ & $\begin{array}{l}\text { sloth } \\
/ \sin \theta /\end{array}$ & $\begin{array}{l}\text { sloth } \\
\text { /slav } \theta /\end{array}$ & 7.14 .13 \\
\hline $\begin{array}{c}\text { sate, soft } \\
/ \text { se:t/,/spft/ }\end{array}$ & $\begin{array}{c}\text { soft } \\
/ \text { se:t/,/spft/ }\end{array}$ & $\begin{array}{l}\text { soft } \\
/ \text { spft/ }\end{array}$ & 7.8.5 \\
\hline $\begin{array}{c}\text { sarra } \\
\text { /sa(:)rə/,/sarə/ }\end{array}$ & $\begin{array}{c}\text { sorrow } \\
\text { /sa(:)rə/, /sarə/ }\end{array}$ & $\begin{array}{l}\text { sorrow } \\
\text { /sprou/ }\end{array}$ & 7.22 .5 \\
\hline $\begin{array}{l}\text { spiarde } \\
\text { /spja:rd/ }\end{array}$ & $\begin{array}{l}\text { speäde } \\
\text { /spjed/ }\end{array}$ & $\begin{array}{l}\text { spade } \\
\text { /speid/ }\end{array}$ & $\begin{array}{l}7.21 .2 \\
8.8 .1\end{array}$ \\
\hline $\begin{array}{l}\text { speer } \\
\text { /spiər/ }\end{array}$ & $\begin{array}{l}\text { speer } \\
\text { /spiər/ }\end{array}$ & $\begin{array}{l}\text { spire } \\
\text { /spaia/ }\end{array}$ & $\begin{array}{l}7.16 .3 \\
8.8 .1\end{array}$ \\
\hline $\begin{array}{l}\text { spwile } \\
\text { /spwə:Il/ }\end{array}$ & $\begin{array}{l}\text { spweil } \\
\text { /spwə:Il/ }\end{array}$ & $\begin{array}{l}\text { spoil } \\
\text { /spoil/ }\end{array}$ & $\begin{array}{l}7.17 .1 \\
8.16 .3\end{array}$ \\
\hline $\begin{array}{l}\text { squerrel } \\
\text { /skwə:rəl/ }\end{array}$ & $\begin{array}{l}\text { squirrel } \\
\text { /skwə:rəl/ }\end{array}$ & $\begin{array}{l}\text { squirrel } \\
\text { /skwirəl/ }\end{array}$ & 7.1.9 \\
\hline $\begin{array}{c}\text { strik, strik' } \\
\text { /strik/ }\end{array}$ & $\begin{array}{c}\text { strik, strik', strike } \\
\text { /strik }\end{array}$ & $\begin{array}{l}\text { strike } \\
\text { /strark/ }\end{array}$ & 7.16 .5 \\
\hline $\begin{array}{c}\text { sure } \\
/ \int \mathrm{u}(:) \partial r /\end{array}$ & $\begin{array}{c}\text { sure } \\
/ \int \mathrm{u}(:) \partial r /\end{array}$ & $\begin{array}{c}\text { sure } \\
/ \text { So:/,/Suo/ }\end{array}$ & $\begin{array}{l}7.24 .1 \\
8.8 .1\end{array}$ \\
\hline $\begin{array}{c}\text { th (voiced) } \\
\text { /ð/ } \\
\text { tharn, thatch, thin, } \\
\text { thing, think, athirt, } \\
\text { thissle, thought }(v .)\end{array}$ & $\begin{array}{c}\text { th (voiced) } \\
/ \text { / / } \\
\text { thorn, thatch, thin, } \\
\text { thing, think, } \\
\text { athwart, thistle, } \\
\text { thought }(v .)\end{array}$ & $\begin{array}{c}\text { th (voiceless) } \\
/ \theta / \\
\text { thorn, thatch, thin, } \\
\text { thing, think, } \\
\text { athwart, thistle, } \\
\text { thought }\end{array}$ & 8.13 .1 \\
\hline $\begin{array}{l}\text { theös } \\
\text { /ðiəs/ }\end{array}$ & $\begin{array}{l}\text { theäse } \\
\text { /ðiəs/ }\end{array}$ & $\begin{array}{l}\text { this } \\
\text { /ðIs/ }\end{array}$ & 7.10 .9 \\
\hline $\begin{array}{l}\text { ther, their } \\
\text { /ðər/,/ðcər/ }\end{array}$ & $\begin{array}{l}\text { their (ther) } \\
\text { /ðər/, /ðcər/ }\end{array}$ & $\begin{array}{l}\text { their } \\
\text { /ðعə/ }\end{array}$ & $\begin{array}{l}7.20 .3 \\
8.8 .1\end{array}$ \\
\hline
\end{tabular}




\begin{tabular}{|c|c|c|c|}
\hline $\begin{array}{l}\text { ther, there } \\
\text { /ðər/, / ठعər/ }\end{array}$ & $\begin{array}{c}\text { there } \\
\text { /ðər/, /ðعər/ }\end{array}$ & $\begin{array}{l}\text { there } \\
\text { /ðعə/ }\end{array}$ & $\begin{array}{l}7.20 .3 \\
8.8 .1\end{array}$ \\
\hline $\begin{array}{c}\text { thā, thae, thāe, } \\
\text { tha, tha', thæ, thē, } \\
\text { they, thēy } \\
\text { /ðe: } /\end{array}$ & $\begin{array}{l}\text { they } \\
\text { /ðe:/ }\end{array}$ & $\begin{array}{l}\text { they } \\
\text { /ðeI/ }\end{array}$ & 7.11 .10 \\
\hline $\begin{array}{l}\text { tidden } \\
\text { /tiden/ }\end{array}$ & $\begin{array}{l}\text { tidden } \\
\text { /tidən/ }\end{array}$ & $\begin{array}{l}\text { 'tisn't } \\
\text { /tIzont/ }\end{array}$ & 8.9 .3 \\
\hline $\begin{array}{l}\text { tooe } \\
/ \text { tu:/ }\end{array}$ & $\begin{array}{l}\text { tooe } \\
/ \text { tu: } /\end{array}$ & $\begin{array}{l}\text { toe } \\
/ \text { tou/ }\end{array}$ & 7.14 .6 \\
\hline $\begin{array}{l}\text { tuèn } \\
\text { / tju:ən/ }\end{array}$ & $\begin{array}{l}\text { tuèn } \\
\text { /tju:ən/ }\end{array}$ & $\begin{array}{l}\text { tune } \\
\text { /tju:n/ }\end{array}$ & 7.15 .2 \\
\hline $\begin{array}{c}\text { twile } \\
\text { /tworil/ }\end{array}$ & $\begin{array}{c}\text { tweil } \\
\text { /twə:Il/ }\end{array}$ & $\begin{array}{l}\text { toil } \\
\text { /torl/ }\end{array}$ & $\begin{array}{l}7.17 .1 \\
8.16 .3\end{array}$ \\
\hline $\begin{array}{c}\text { twirdle } \\
\text { /twordəl/ }\end{array}$ & $\begin{array}{c}\text { twirl } \\
\text { /twa:l/,/twa:rdəl/ }\end{array}$ & $\begin{array}{l}\text { twirl } \\
\text { /twəil/ }\end{array}$ & 8.8 .4 \\
\hline $\begin{array}{c}\mathbf{u} \\
/ \Lambda / \\
\text { put, puddèn, ruf, } \\
\text { buzzom }\end{array}$ & $\begin{array}{c}\mathbf{u} \\
/ \Lambda / \\
\text { put, puddèn, ruf, } \\
\text { bosom }\end{array}$ & $\begin{array}{c}\mathbf{u} \\
/ \mathrm{U} / \\
\text { put, pudding, roof, } \\
\text { bosom }\end{array}$ & 7.5.2 \\
\hline $\begin{array}{c}\text { ur+C } \\
\text { /ərr/ } \\
\text { burn, church, turn, } \\
\text { vurdest }\end{array}$ & $\begin{array}{c}\text { ur+C } \\
\text { / orr/ } \\
\text { burn, church, turn, } \\
\text { vurdest }\end{array}$ & $\begin{array}{c}\text { ur+C } \\
/ \partial: / \\
\text { burn, church, turn, } \\
\text { furthest }\end{array}$ & $\begin{array}{l}7.9 .1 \\
8.8 .1\end{array}$ \\
\hline $\begin{array}{c}\mathbf{v} \text { (initial) } \\
/ \mathrm{v} / \\
\text { val, var, veed, vetch, } \\
\text { vind, vlee, vo'ke, } \\
\text { voun', vull, vuzz }\end{array}$ & $\begin{array}{c}\mathbf{v} \text { (initial) } \\
\text { /v/ } \\
\text { vall, vor, veed, } \\
\text { vetch, vind, vlee, } \\
\text { vo'k, voun', vull, } \\
\text { vuzz }\end{array}$ & $\begin{array}{l}\mathbf{f}(\text { initial) } \\
/ \mathrm{f} / \\
\text { fall, for, feed, find, } \\
\text { fly, folk, found, full, } \\
\text { furze }\end{array}$ & 8.3 .1 \\
\hline $\begin{array}{l}\text { vâice } \\
\text { /væIs/ }\end{array}$ & $\begin{array}{l}\text { vaïce } \\
\text { /væIs/ }\end{array}$ & $\begin{array}{l}\text { voice } \\
\text { /vors/ }\end{array}$ & 7.17 .2 \\
\hline
\end{tabular}




\begin{tabular}{|c|c|c|c|}
\hline $\begin{array}{l}\text { vlee, vlees } \\
\text { /vli:/, /vlizz/ }\end{array}$ & $\begin{array}{l}\text { vlee, vlees } \\
\text { /vli:/, /vliiz/ }\end{array}$ & $\begin{array}{c}\text { fly, flies } \\
\text { /flai/, / flaiz/ }\end{array}$ & 7.16 .6 \\
\hline $\begin{array}{c}\text { vlour } \\
\text { /vluər/,?/vləuər/ }\end{array}$ & $\begin{array}{l}\text { vloor } \\
\text { /vluør/ }\end{array}$ & $\begin{array}{l}\text { floor } \\
\text { /flo:/ }\end{array}$ & $\begin{array}{l}7.23 .3 \\
8.8 .1\end{array}$ \\
\hline $\begin{array}{l}\text { vust } \\
\text { /vsst/ }\end{array}$ & $\begin{array}{l}\text { vu'st } \\
\text { /v } \Lambda \text { st/ }\end{array}$ & $\begin{array}{c}\text { first } \\
\text { /fərst/ }\end{array}$ & $\begin{array}{l}7.9 .5 \mathrm{c} \\
8.8 .5\end{array}$ \\
\hline $\begin{array}{l}\text { vuzz } \\
/ \mathrm{v} \wedge \mathrm{z} /\end{array}$ & $\begin{array}{l}\text { vuzz } \\
\text { /vız/ }\end{array}$ & $\begin{array}{l}\text { furze } \\
\text { /fa:z/ }\end{array}$ & $\begin{array}{l}7.9 .5 f \\
8.8 .5\end{array}$ \\
\hline $\begin{array}{l}\text { wages } \\
\text { /wE:d3Iz/ }\end{array}$ & $\begin{array}{c}\text { wages } \\
\text { /we:d3Iz/ }\end{array}$ & $\begin{array}{l}\text { wages } \\
\text { / weid3Iz/ }\end{array}$ & 7.11 .13 \\
\hline $\begin{array}{c}\text { way, woy } \\
\text { /we:/,/wə:I/, } \\
\text { /wæI/ }\end{array}$ & $\begin{array}{l}\text { way, wä̈, woy } \\
\text { /we:/, /wæi/, } \\
\text { /wə:I/ }\end{array}$ & $\begin{array}{l}\text { way } \\
\text { /weI/ }\end{array}$ & 7.11 .8 \\
\hline $\begin{array}{l}\text { wēak, weak } \\
\text { /we:k/,/wi:k/ }\end{array}$ & $\begin{array}{l}\text { weak (weäk) } \\
\text { /we:k/,/wiok/ }\end{array}$ & $\begin{array}{l}\text { weak } \\
\text { /wi:k/ }\end{array}$ & 7.10 .14 \\
\hline $\begin{array}{l}\text { weir } \\
\text { /weər/ }\end{array}$ & $\begin{array}{l}\text { weir } \\
\text { /weor/ }\end{array}$ & $\begin{array}{l}\text { weir } \\
\text { /wiə/ }\end{array}$ & $\begin{array}{l}7.19 .5 \\
8.8 .1\end{array}$ \\
\hline $\begin{array}{c}\text { wher, where } \\
\text { /(h)wər/,/(h)weər/ }\end{array}$ & $\begin{array}{c}\text { wher, where } \\
\text { /(h)wər/,/(h)weər/ }\end{array}$ & $\begin{array}{l}\text { where } \\
\text { /(h)weə/ }\end{array}$ & $\begin{array}{l}7.20 .3 \\
8.8 .1\end{array}$ \\
\hline $\begin{array}{c}\text { whirdle } \\
\text { /(h)wə:rdəl/ }\end{array}$ & $\begin{array}{l}\text { whirl } \\
\text { /(h)wə:rl/, } \\
\text { /(h)wə:rdəl/ }\end{array}$ & $\begin{array}{c}\text { whirl } \\
\text { /(h)wə:l/ }\end{array}$ & $\begin{array}{l}8.5 .3 \\
8.8 .4\end{array}$ \\
\hline $\begin{array}{l}\text { huosse } \\
\text { /huəs/ }\end{array}$ & $\begin{array}{l}\text { whoa'se } \\
\text { /huəs/ }\end{array}$ & $\begin{array}{l}\text { hoarse } \\
\text { /ho:s/ }\end{array}$ & 7.23.6a \\
\hline $\begin{array}{l}\text { wi' } \\
\text { /wi/ }\end{array}$ & $\begin{array}{l}\text { wi' } \\
\text { /wi/ }\end{array}$ & $\begin{array}{l}\text { with } \\
\text { /wið/ }\end{array}$ & $\begin{array}{l}7.1 .7 \\
8.13 .2\end{array}$ \\
\hline $\begin{array}{c}\text { wo, woa (initial) } \\
\text { /(w)uə/ } \\
\text { wold, woak, woats, } \\
\text { woath }\end{array}$ & $\begin{array}{c}\text { wo, woa (initial) } \\
\text { /(w)uə/ } \\
\text { wold, woak, woats, } \\
\text { woath }\end{array}$ & $\begin{array}{c}\text { o, oa (initial) } \\
\text { /əu/ } \\
\text { old, oak, oats, oath }\end{array}$ & 7.14 .4 \\
\hline
\end{tabular}




\begin{tabular}{|c|c|c|c|}
\hline $\begin{array}{l}\text { uo, uoa, uo+C+e } \\
\text { / uə/ } \\
\text { buold, cuomb, } \\
\text { huome, luoad, luoaf, } \\
\text { ruope, stuone }\end{array}$ & $\begin{array}{c}\text { wo, woa, wo+C+e } \\
\text { /uə/ } \\
\text { bwold, cwomb, } \\
\text { hwome, lwoad, } \\
\text { lwoaf, rwope, } \\
\text { stwone }\end{array}$ & $\begin{array}{c}\text { o, oa, o+C+e } \\
\text { /ov/ } \\
\text { bold, comb, home, } \\
\text { load, loaf, rope, } \\
\text { stone }\end{array}$ & $7.14 .1-3$ \\
\hline $\begin{array}{l}\text { wust } \\
\text { /wnst/ }\end{array}$ & $\begin{array}{c}\text { wo'st (worst) } \\
\text { /w } \Lambda \text { st / }\end{array}$ & $\begin{array}{l}\text { worst } \\
\text { /warst/ }\end{array}$ & $\begin{array}{l}7.9 .5 \mathrm{c} \\
8.8 .5\end{array}$ \\
\hline $\begin{array}{c}\text { wo'th } \\
\text { /woth/, /wsth/ }\end{array}$ & $\begin{array}{c}\text { wo'th } \\
\text { /woth/,/wath/ }\end{array}$ & $\begin{array}{l}\text { worth } \\
/ \text { wə: } \theta /\end{array}$ & $\begin{array}{l}7.9 .5 \mathrm{e} \\
8.8 .5\end{array}$ \\
\hline $\begin{array}{c}\text { women } \\
\text { /wəmin/,/wumin/ }\end{array}$ & $\begin{array}{c}\text { women } \\
\text { /womin/,/wumin/ }\end{array}$ & $\begin{array}{l}\text { women } \\
\text { /wimin/ }\end{array}$ & 7.1 .10 \\
\hline $\begin{array}{c}\text { won't } \\
\text { /wu(:)nt/ }\end{array}$ & $\begin{array}{l}\text { won't, wont } \\
\text { /wu(:)nt/ }\end{array}$ & $\begin{array}{l}\text { won't } \\
\text { /wount / }\end{array}$ & 7.14.14 \\
\hline $\begin{array}{l}\text { woose } \\
\text { /wuis/ }\end{array}$ & $\begin{array}{c}\text { woo'se (woose) } \\
\text { /wuis/ }\end{array}$ & $\begin{array}{l}\text { worse } \\
\text { /wors/ }\end{array}$ & $\begin{array}{l}7.9 .5 \mathrm{~b} \\
8.8 .5\end{array}$ \\
\hline $\begin{array}{c}\text { wool } \\
\text { /wul/,/wu:l/ }\end{array}$ & $\begin{array}{c}\text { wool } \\
\text { /wul/,/wu:l/ }\end{array}$ & $\begin{array}{l}\text { wool } \\
\text { /wol/ }\end{array}$ & 7.6.4 \\
\hline $\begin{array}{c}\text { oonce } \\
\text { /(w)uins / }\end{array}$ & $\begin{array}{l}\text { woonce } \\
\text { /(w)u:ns/ }\end{array}$ & $\begin{array}{l}\text { once } \\
\text { /wAns/ }\end{array}$ & 7.5.7 \\
\hline $\begin{array}{l}\text { oon, oone } \\
/(\mathrm{w}) \text { u:n/ }\end{array}$ & $\begin{array}{c}\text { woone (oone) } \\
/(\mathrm{w}) \text { un } /\end{array}$ & $\begin{array}{l}\text { one } \\
/ \mathrm{w} \Lambda \mathrm{n} /\end{array}$ & 7.5.7 \\
\hline $\begin{array}{c}\text { wordle } \\
\text { /warrdel/ }\end{array}$ & $\begin{array}{l}\text { worold } \\
\text { /wə:rdəl/ }\end{array}$ & $\begin{array}{l}\text { world } \\
\text { /wə:ld/ }\end{array}$ & 8.8 .4 \\
\hline $\begin{array}{c}\text { 'ood, 'od, woud, } \\
\text { would } \\
/(\mathrm{w}) \mathrm{ud} /\end{array}$ & $\begin{array}{l}\text { would (woud) } \\
\text { /(w)ud/ }\end{array}$ & $\begin{array}{l}\text { would } \\
\text { /wud/ }\end{array}$ & 8.16 .1 \\
\hline $\begin{array}{c}\text { 'ool, 'ul, 'ull, wull, } \\
\text { will } \\
\text { /(w)wl/, /wil/ }\end{array}$ & $\begin{array}{l}\text { wull ('ull), will } \\
\text { /(w)ul/, /wil/ }\end{array}$ & $\begin{array}{l}\text { will } \\
\text { /wil/ }\end{array}$ & 8.16 .1 \\
\hline
\end{tabular}




\begin{tabular}{|c|c|c|c|}
\hline $\begin{array}{c}\text { ye (attached to } \\
\text { antecedent }) \\
\text { /i:/ } \\
\text { can ye, tell ye, var ye }\end{array}$ & $\begin{array}{c}\text { ye (attached to } \\
\text { antecedent) } \\
\text { /i: } / \\
\text { can ye, tell ye, vor } \\
\text { ye }\end{array}$ & $\begin{array}{c}\text { ye } \\
/ \mathrm{ji}(:) /\end{array}$ & 8.18 \\
\hline $\begin{array}{c}\text { year } \\
\text { /jior/,/jərr/ }\end{array}$ & $\begin{array}{c}\text { year } \\
\text { /jior/,/jarr/ }\end{array}$ & $\begin{array}{l}\text { year } \\
\text { /jio/ }\end{array}$ & $\begin{array}{l}7.19 .3 \\
8.8 .1\end{array}$ \\
\hline $\begin{array}{c}\text { yaller, yoller } \\
\text { /jalər/ }\end{array}$ & $\begin{array}{c}\text { yollow (yollor, } \\
\text { yellow) } \\
\text { /jalor/ }\end{array}$ & $\begin{array}{l}\text { yellow } \\
\text { /jeləu/ }\end{array}$ & $\begin{array}{c}7.4 \\
7.14 .8 \\
8.8 .2 \\
\end{array}$ \\
\hline $\begin{array}{l}\text { yander } \\
\text { /jandər/ }\end{array}$ & $\begin{array}{l}\text { yonder } \\
\text { /jander/ }\end{array}$ & $\begin{array}{l}\text { yonder } \\
\text { /jonde/ }\end{array}$ & $\begin{array}{c}7.4 \\
8.8 .1\end{array}$ \\
\hline $\begin{array}{c}\text { ya (unstressed) } \\
/ \mathrm{j} ə /\end{array}$ & $\begin{array}{c}\text { you (unstressed) } \\
/ \mathrm{j} ə /\end{array}$ & $\begin{array}{l}\text { you } \\
\text { /ju:/ }\end{array}$ & 7.15 .5 \\
\hline $\begin{array}{l}\text { your, yer, yar } \\
\text { /ju(:)ər/,/jər/ }\end{array}$ & $\begin{array}{c}\text { your } \\
\text { /ju(:)ər/,/jər/ }\end{array}$ & $\begin{array}{c}\text { your } \\
/ \text { jo:/,/juo/,/jə/ }\end{array}$ & $\begin{array}{c}7.24 .2 \\
8.8 .1\end{array}$ \\
\hline $\begin{array}{c}\mathbf{z} \text { (initial) } \\
\text { /z/ } \\
\text { zack, zaid, zee, zell, } \\
\text { zing, zit, zong, zoo, } \\
\text { zummer, zun }\end{array}$ & $\begin{array}{c}\text { z (initial) } \\
\text { /z/ } \\
\text { zack, zaid, zee, zell, } \\
\text { zing, zit, zong, zoo, } \\
\text { zummer, zun }\end{array}$ & $\begin{array}{c}\text { s (initial) } \\
\text { /s/ } \\
\text { sack, said, see, sell, } \\
\text { sing, sit, song, so, } \\
\text { summer, sun }\end{array}$ & 8.9.1 \\
\hline $\begin{array}{l}\text { zuf, zelf } \\
\text { /zへf/ }\end{array}$ & $\begin{array}{c}\text { zelf (zuf) } \\
\text { /zuf/ }\end{array}$ & $\begin{array}{l}\text { self } \\
\text { /self/ }\end{array}$ & 7.5.2 \\
\hline $\begin{array}{c}\text { zome'hat, zummat } \\
\text { /zımət/ }\end{array}$ & $\begin{array}{c}\text { zome'hat } \\
\text { (zome'at) } \\
\text { /zımot/ }\end{array}$ & $\begin{array}{l}\text { somewhat } \\
/ \mathrm{s} \Lambda \mathrm{m}(\mathrm{h}) \mathrm{wpt} /\end{array}$ & $\begin{array}{l}8.16 .2 \\
8.17 .2\end{array}$ \\
\hline $\begin{array}{c}\text { zoo ('and so, } \\
\text { therefore') } \\
\text { /zu: }\end{array}$ & $\begin{array}{c}\text { zoo ('and so, } \\
\text { therefore') } \\
\text { /zu:/ }\end{array}$ & $\begin{array}{l}\text { so } \\
\text { / səu/ }\end{array}$ & 7.14 .6 \\
\hline $\begin{array}{l}\text { zot } \\
\text { /zat/ }\end{array}$ & $\begin{array}{l}\text { zot } \\
\text { /zat/ }\end{array}$ & $\begin{array}{c}\text { sat } \\
\text { /sæt/ }\end{array}$ & 7.3.2 \\
\hline
\end{tabular}




\section{A note on the text}

The text of the poems follows that of 1879. Minor mechanical errors are silently corrected (unpaired quotation marks, apostrophes omitted where spaces have been left for them, full stops used where commas are evidently intended, etc.); more substantial emendations are recorded in the Textual Notes. Marginal glosses are supplied in italics for words that may cause temporary hesitation; where the same word occurs within a few lines of an earlier gloss, the gloss is not repeated. Double quotation marks are used for direct speech, for quotations, and for titles of poems and journal articles; single quotation marks are reserved for definitions and translations.

The phonemic transcripts on the pages facing the poems are based on the findings recorded in WBPG. They show the target pronunciation that is aimed at (though doubtless not always achieved) in the accompanying audio recordings. In numerous instances alternative pronunciations would be equally acceptable: most such alternatives are listed in the table of Common Alternatives on p. xvii.

\section{"Childhood": a line-by-line phonemic analysis}

References in parentheses are to line numbers in the poem; those in square brackets are to sections and subsections in WBPG and to the summary of those sections in the Appendix to this volume. No comment is made on words that have the same pronunciation as in RP. Dialect pronunciations are normally pointed out only on their first occurrence in the poem.

\section{Title Childhood}

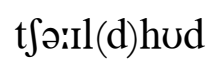

Child-. (i) The usual pronunciation of the diphthong in child (/aI/ or / $\mathrm{\Lambda I} /$ in current RP) is /o:I/ in Barnes's dialect, as in time and times (lines 1 and 5), life (4), bindèn (7), high (9), wide (10), buyèn (18), etc. [7.16.1]. (ii) Final /d/ in the consonant cluster $/ \mathrm{ld} /$ is optional [8.2.2], allowing rhymes such as chile/smile as well as child/spweil'd, both of which occur in "Fatherhood". 
1 AYE, at that time our days wer but vew, æI ət ðat tə:Im ə:uər de:z wər bət vju:

Aye. For the transcription /æI/ for both aye 'yes' (as here) and aye 'ever' see WBPG 7.11.6.

that. (i) Short $a$ in Barnes's dialect, as in stressed that here, narrow and barrow (10 and 14), lands and hands (17 and 19), etc. is /a/ as opposed to oldfashioned RP /æ/ [7.3.1]. (ii) When that is unstressed (as in lines 9, 10, and 11), however, the vowel (as in StE) is reduced to schwa, /ə/.

our. (i) The diphthong pronunced /av/ in RP, as in our here, sproutèn (5), bousen (9), 'ithout (18), etc. is in Barnes's dialect /aru/, similar to that in RP go, blow, hoe, etc. [7.18.1]. In words such as our and flour, however, the following $r$ turns the diphthong into a triphthong, as in RP, allowing the word to be treated as monosyllabic or disyllabic as required by the rhythm. (ii) The $r$ is sounded in Barnes's dialect, though silent in RP [8.8.1]. This applies to all words in which Barnes retains the $r$ in spelling where it would be silent in RP, whether at the end of a word, as in our here, feäir (3), or (14), etc., or before a consonant, as in burnèn (6), rivers (17), childern (25), etc., or when followed only by mute $e$, as in avore (20) and bore (24). In such cases the $e$ is often omitted from the spelling, as in wer $(1,2,3$, etc.). When the $r$ is not sounded in the dialect (as in birth, bearth, horse, etc.), Barnes omits it from the spelling [8.8.5].

days. The sound in most words spelled with ay or ey in StE (ususally ay in the modified form of the dialect) is /æI/ in Barnes's dialect; but day, clay, fay ( $v$. 'succeed, prosper'), lay, say, way, grey, key, and whey, normally have the vowel /e:/ [7.11.7; for way and away see further 7.11.8].

vew. Initial / $\mathrm{f} /$ is voiced in the dialect in most native English words [8.3.1]. Barnes uses $v$ to show this voicing, as in vew for few here, vlee (11), veelèns (12), and the second element of hopevul (4). His spelling shows, on the other hand, that the initial /f/ is not normally voiced in words adopted from French, such as feeble (12). But there are exceptions on both sides, such as feär (3), a native English word that is always spelled with $f$, 
showing a voiceless initial consonant, and veäiry ('fairy'), a borrowing from French always shown with voiced initial consonant.

2 An' our lim's wer but small, an' a-growèn; ən ə:uər limz wər bət sma:l ən əgro:ən

$A n^{\prime}$. Final /d/ is frequently lost from the consonant cluster /nd/ [8.2.2], as shown by its omission from and throughout this poem. This allows words ending in -nd in StE to rhyme with words ending in either $n$ or $n d$; hence ground rhymes with -drown' $d$ (with obligatory final $d$ in the past participle) in the final stanza of "The blackbird [II]" but with crown and down in the second stanza of "Bleäke's house in Blackmwore". Cf. Child- (ii) above.

small. Words containing the sound /o:l/ in RP, such as all (4, 8, etc.), haul, and crawl, are spelled as in StE in later editions but variously spelled in 1844. The usual pronunciation in Barnes's dialect is /a:l/ [7.13.1].

-growèn. (i) The vowel that has become the diphthong /ov/ in RP was in some words in Barnes's dialect the pure vowel /o:/, as in grow here, hopevul (4), mowèn (6), etc., and in others the diphthong /uə/, spelled wo in the modified form of the dialect, as in wold (22) and covold (31) [7.14, 7.14.1-3, 7.14.14]. (ii) In both the broad and the modified forms of the dialect Barnes uses the spelling -in for the unstressed -ing ending on present participles and verbal nouns, though the accent on the $e$ is sometimes omitted. The pronunciation, as for other words ending in unstressed -en (past participles of strong verbs, nouns such as garden, etc.), is /on/ [7.1.5].

\section{An' then the feäir worold wer new,} ən ðعn ðə fjeər wə:rdəl wər nju:

feär. (i) The word belongs with hair, pair, mare, share, etc., always spelled with -eäir (for StE -air) or -eäre (for StE -are) in the modified form of the dialect. The diphthong is pronounced as in RP / $/$ ə / with an introductory $i$-glide, creating the triphthong $/ \mathrm{j} \varepsilon a /$, followed by $/ \mathrm{r} /$ (see our above), hence /jeər/[7.20.2]. (ii) For the voiceless initial /f/ see vew above. 
worold. (i) In 1844 world is always spelled wordle, in accordance with Barnes's comment in $\$ 33$ of the prefatory Dissertation: "The liquids $r$ of English words, such as purl, twirl, world, have frequently $d$ inserted between them, making purdle, twirdle, wordle". The respelling worold in the modified form of the dialect (modelled on OE weorold) shows that world is disyllabic while remaining close to the StE spelling; I take it, however, that the pronunciation remains /wə:rdal/, as in the broad form of the dialect.

4 An’ life wer all hopevul an' gaÿ;
ən lə:If wər a:l ho:pvul ən gæı

gaj. Words spelled with ai or ay in $\mathrm{StE}$ and pronounced /eI/ in RP are normally spelled $a \ddot{i}$ or $a \ddot{y}$ in the modified form of the dialect (sometimes $\ddot{a} i$ or äy). The pronunciation in Barnes's dialect is /æI/ as in Australian $G^{\prime} d a y$. (For day, say, and other words spelled with ay as opposed to ayj see days in line 1 above.)

5 An' the times o' the sproutèn o' leaves, ən ðə tə:Imz ə ðə sprə:utən ə liivz

o. $\quad / \mathrm{v} /$ in of is commonly lost before a consonant, yielding the pronunciation / / / [8.3.2].

sproutèn. (i) For the diphthong in the stem see our (line 1 above); (ii) for the -èn ending see -growèn (line 2 above).

6 An' the cheäk-burnèn seasons o' mowèn, ən ðə tfiəkbə:rnən si:zənz ə mo:ən

cheäk-. The vowel in words spelled with ee in StE is not normally diphthongized in Barnes's dialect. Cheek is an exception (as shown by the eä spelling) suggesting that the dialect form, with the diphthong /io/ in place of RP /is/, is derived from the West Saxon ceace (as might be expected in the SW), whereas the StE form is from Anglian cèce [7.10.8, 7.10.13]. 
burnèn. (i) The vowel of the stem is /ə:/, as in RP [7.9.1]; for retention of $/ \mathrm{r} /$ after the vowel see our (line 1 above) [8.8.1].

7 An' bindèn o' red-headed sheaves, ən bə:In(d)ən ə redhedid Ji:vz

$8 \quad$ Wer all welcome seasons o’ jä̈. wər a:l welkəm si:zənz ə dzæı

jaj. The diphthong in joy in Barnes's dialect is usually /æI/, as shown here by the rhyme with gaij and the spelling äj; occasional rhymes with boy show that it can also be /a:I/ [7.17.3]. The diphthong in words spelled with oi in StE and $a \ddot{i}$ in the modified form of the dialect (noise, rejoice, voice, etc.) is likewise /æI/ [7.17.2].

9 Then the housen seem'd high, that be low, ðعn ðə hə:uzən si(:)md hə:I ðət bi: lo:

bousen. (i) "Many nouns have in the Dorset dialect the old plural termination en instead of $s$ : as cheesen, cheeses; housen, houses; vuzzen, (furzen,) furzes ..." (1844 Dissertation, \44); for the pronunciation /on/ see -growèn (line 2 above). (ii) For the vowel of the stem see our (line 1 above).

seem'd. The vowel in most words spelled with $e e$ in StE is pronounced /i:/ in Barnes's dialect, as in RP; like keep, meet, and week, however, seem is sometimes spelled with $i$ for ee in 1844, indicating an alternative pronunciation with short $i$. The transcription $/ \mathrm{i}(\mathrm{i}) /$ permits both possibilities [7.10.11].

10 An' the brook did seem wide that is narrow, ən ðə bruk did si(:)m wə:Id ðət Iz narə(r)

narrow. "ow at the end of a word as fellow, hollow, mellow, pillow, yellow, mostly become er, making those words feller, holler, meller, piller, yoller" (1844 Dissertation, \$27). For the transcription of the unstressed final syllable as /o(r)/ here and in Bulbarrow (line 14) see WBPG 7.14.8. 
11 An' time, that do vlee, did goo slow, ən tə:Im ðət də vli: dıd gu: slo:

do. The use of do and did in this line perfectly illustrates Barnes's comment on verb tenses in the Dorset dialect in $\$ 53$ of the 1844 Dissertation: "A verb is commonly conjugated in the present tense with the auxiliary verb $d o, d a \ldots$ and in the imperfect tense with did" (though seem'd in line 9 beside did seem in 10 shows that $\mathrm{StE}$ tense-formation was also acceptable). When used as an auxiliary, as here, do is normally the unstressed /do/ [7.15.5]; when stressed, on the other hand, it is /du:/. In 1844 Barnes consistently uses the spelling $d a$ for the unstressed auxiliary and do elsewhere, but in the modified form of the dialect the $d a$ spellings are gradually phased out until they are entirely replaced by do (see WBCP ii, Appendix 3).

goo. Go and ago, no (in the sense 'not any'), so (in the sense 'and so, therefore'), sloe, and toe are almost invariably spelled with oo or ooe in both the broad and the modified forms of the dialect, and are rhymed with words ending in the sound /u:/, such as blue, shoe, two, etc. [7.14.6]. The pronunciation of goo is evidently /gu:/, though rare exceptions, such as the rhyme rwose/ nose/ goes in "The shy man" (41-3), show /go:/ as a possible variant.

12 An' veelèns now feeble wer strong, ən vi:lənz nə:u fi:bəl wər stroy

13 An' our worold did end wi' the neämes ən ə:uər wərrdəl did $\varepsilon n(d)$ wi ðə njєmz

wi'. This is Barnes's normal spelling of with in both the broad and the modified forms of the dialect, showing the loss of final $/ \delta /$, with raising and possibly lengthening of the preceding vowel from /I/ to /i/ or /i:/ [7.1.7 and 8.13.2]. 
neämes. The spelling used in the modified form of the dialect for the diphthong in the sequence spelled $\mathrm{C}+a+\mathrm{C}+e$ and pronounced /eI/ in StE is eä, as in geämes (15) and teäke (27), replacing the broad form's $i a$. The pronunciation in Barnes's dialect is $/ \mathrm{j} \varepsilon /$ [7.11.1]. The disadvantage of the decision to replace $i a$ with $e \ddot{a}$ is the potential confusion of this diphthong with the /iə/ of words such as feast and leave, spelled with eä in both the broad and the modified forms of the dialect and pronounced /i:/ in RP (see leäve in line 23 below).

\section{Ov the Sha'sbury Hill or Bulbarrow; əv ðə faisbəri hil ar bulbarə(r)}

Sha'sbury. (i) The loss of /fts/ in Shaftesbury is similar to that of / $\mathrm{f} /$ in after, but it is not possible to say whether or not the vowel of the first syllable should be / $\varepsilon$ : / as in àter (see [7.7.4]). For want of further evidence I take the vowel to be /a:/ [7.7.1]. (ii) The vowel of the unstressed $-y$ ending, here and in rilvery (18), bappy (25), etc., is not /I/ as in old-fashioned RP, but $/ \mathrm{i} /$.

or. Words spelled with or in StE representing /o:/ or /orr/ in RP, such as or here, storm (31), etc. are consistently spelled with ar in 1844, indicating the pronunciation /a:r/. When the syllable is unstressed, however (as frequently with for, or, nor), the pronunciation is reduced (as here) to /ar/ or /or/ [7.22.1-3].

15 An' life did seem only the geämes ən lə:If did si(:)m o:nli ðə gjemz

16 That we plaÿ'd as the days rolled along. ðət wi: plæId əz ðə de:z ro:ld əlpy

17 Then the rivers, an' high-timber'd lands, ðદn ðə rivərz ən hə:ItImbərd $\operatorname{lan}(\mathrm{d}) \mathrm{z}$ 
18 An' the zilvery hills, 'ithout buyèn, ən ðə zılvəri hilz ıðə'ut bə:ıən

zilvery. "S before a vowel often but not universally becomes in Dorset its smooth kinsletter z, making sand, zand; sap, zeap; send, zend; set, zet; ..." (1844 Dissertation, §36; [8.9.1]). Barnes consistently spells words with ₹when the initial sound is voiced, as in zilvery here, zickness (21), zome (28), etc., in contrast to those in which the /s/ remains voiceless, as in small (2), seasons (8), seem'd (10), etc.

ithout. Loss of initial /w/ is common in SW dialects. Where Barnes's spelling indicates this loss, as here, I omit / w/ in the transcript; in words in which the $w$ is never omitted from the spelling (e.g. wood), /w/ is retained in the transcript; in words spelled sometimes with and sometimes without $w$ (e.g within and without) the transcript records /(w)/ in those instances where Barnes's spelling retains the $w$ [8.16.1].

19 Did seem to come into our hands did si(:)m tə kım Intu ə:uər han(d)z

20 Vrom others that own'd em avore; vrəm $\Lambda$ ðrz ðət o:nd əm əvuər

em. Loss of initial /ð/ in them and reduction of the vowel to / / / as here is common in colloquial English in all dialects as well as StE.

avore. (i) The pronunciation in Barnes's dialect of the combination ore as in -vore here, vorefathers and bore (24), etc., as of most words spelled with or $+C$, oar, oor, or our representing the sound /o:/ in RP (/or/ when followed by a vowel), is generally /uər/ [7.23, 7.23.1]. (ii) Barnes's usage shows a marked preference for avore over bevore, the former outnumbering the latter in his poems in a ratio of nearly five to one. (iii) For the voicing of the $\mathrm{StE} f$ (in both words) see vew (line 1 above).

21 An' all zickness, an' sorrow, an' need, ən a:l ziknis ən sarə(r) ən ni:d 
sorrow. (i) For the vowel in the first syllable (between $/ \mathrm{p} /$ and $/ \mathrm{a} /$ ) see 7.22.5. (ii) For the unstressed second syllable see narrow (ii) and (iii) in line 10 above.

22 Seem'd to die wi' the wold vo'k a-dyèn, si(:)md tə də:I wi ðə (w) uəld vo:k ədə:ıən

wold. (i) The wo spelling for the vowel that has become the diphthong / ov/ in RP represents /uo/ in Barnes's dialect (see under growèn in line 2 above). (ii) For optional pronunciation of $/ \mathrm{w} /$ in words beginning with $o$ in StE (old, oak, etc.) see WBPG [7.14.4].

\section{An' leäve us vor ever a-freed} ən liəv əs vər عvər əfri:d

leäve. Words spelled with ea in StE and pronounced /i:/ in RP may in Barnes's dialect have either the same spelling and pronunciation, as in leaves (noun) in line 5 , seasons (6 and 8 ), sheaves (7), etc., or the diphthong /iə/ spelled eä in both the broad and the modified forms of the dialect, as in leäve (verb) here, cleän, feäst, etc. [7.10.8]. But the distinction is not absolute: leaves (noun) rhymes with eäves in "The Leädy's Tower" (35-6) and is itself occasionally spelled leäves, as in "Wayfeärèn" (38) and "Beauty undecked" (10).

24 Vrom evils our vorefathers bore. vrəm iivəlz ə:uər vuərfદ:ðərz buər

vorefathers. (i) The vowel in the stressed syllable of fathers is not /a:/ as in RP but / $\varepsilon: /[7.7 .1,7.7 .4]$. (ii) For vore- and bore see avore (20 above).

25 But happy be childern the while bət hapi bi: tfıldərn ðə (h)wə:ıl

childern. This is the standard form in both the broad and the modified forms of the dialect, though there are occasional occurrences of StE children in 
poems not included in 1879, e.g. "Shop o' meatweäre (W $i$ ' children an' other vo'k in house)". On the widespread metathesis of $r+$ vowel in SW dialects see WBPG 8.8.3.

while. The initial consonant sound in words with initial wh may be either aspirated /hw/, as in careful RP, or unaspirated /w/ [8.5.3].

26 They have elders a-livèn to love $\mathrm{em}$,

ðe: hav cldərz əlıvən tə $1 \Lambda \mathrm{v}$ əm

They. The vowel sound is /e:/ as in day, clay, etc. (see days in line 1 above) rather than the StE diphthong /eI/ [7.11.10].

27 An' teäke all the wearisome tweil ən tjek a:l ðə wiərisəm twəil

tweil. (i) The rhyme with while (25) shows that toil has the same vowel in Barnes's dialect, i.e. the diphthong / a:I/ as opposed to RP /aI/ (see Childin the title of this poem). This is true of many words spelled with oi or $y$ pronounced /oI/ in StE [7.17.1], but excludes others such as voice and joy (see jay in line 8 above). (ii) For the insertion of /w/ before /a:I/ in Barnes's dialect and in the SW generally see WBPG 8.16.3.

28 That zome hands or others mus' do; ðət zım han(d)z ər $\Lambda$ ðrz məs du:

mus'. (i) As in RP the vowel in must may be either $/ \Lambda /$ when stressed or $/ \partial /$ when unstressed [7.5.10]. (ii) The final $/ \mathrm{t} /$ is particularly likely to be lost when the word is unstressed, as here.

29 Like the low-headed shrubs that be warm, lik ðə lo:hedıd $\int \mathrm{r} \Lambda \mathrm{bz}$ ðət bi: wa:rm

Like. Both spelling and rhyme in 1844 show that climb, strike, and like (as an adverb or in the past tense) have a short $i, / \mathrm{I} /$. As an infinitive, however, like appears to have the usual diphthong / a:I/ [7.16.5]. 
warm. Like words spelled with or in StE representing / $\mathbf{s}(\mathrm{r}) /$ in RP (see or in line 14 above), words with ar representing the same sound (e.g. warm, swarm, toward) have the sound /arr/ in Barnes's dialect; hence the rhyme sound in warm/ storm (29/31) is not/o:m/ as in RP but/a:rm/ [7.22.2].

30 In the lewth o' the trees up above em,

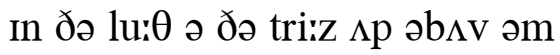

31 A-screen'd vrom the cwold blowèn storm əskri:nd vrəm ðə kuəld blo:ən sta:rm

32 That the timber avore em must rue. ðət ðə tImbər əvuər əm məs(t) ru: 
SECOND-COLLECTION POEMS

WITH

PHONEMIC TRANSCRIPTS 
THE primrwose in the sheäde do blow, bloom

The cowslip in the zun,

The thyme upon the down do grow,

The clote where streams do run;

yellow water-lily

An' where do pretty maïdens grow

An' blow, but where the tow'r

bloom

Do rise among the bricken tuns,

In Blackmwore by the Stour.

If you could zee their comely gait,

An' pretty feäces' smiles,

A-trippèn on so light o' waïght,

An' steppèn off the stiles;

A-gwain to church, as bells do swing

A ring 'ithin the tow'r,

You'd own the pretty maïdens' pleäce

Is Blackmwore by the Stour.

If you vrom Wimborne took your road,

To Stower or Paladore,

An' all the farmers' housen show'd

Their daughters at the door;

You'd cry to bachelors at hwome-

"Here, come: 'ithin an hour

You'll vind ten maïdens to your mind,

In Blackmwore by the Stour.”

An' if you look'd 'ithin their door,

To zee em in their pleäce,

A-doèn housework up avore

Their smilèn mother's feäce; 
blakmuər mæıdənz

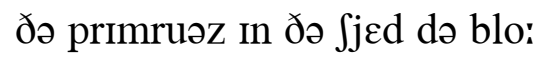

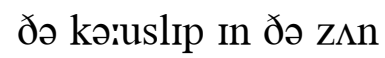

ðə tə:Im əppn ðə də:un də gro:

ðə klo:t (h)wər stri:mz də rAn

ən (h)wər də pərrti mæidənz gro:

ən blo: bət (h)wər ðə tə:uər

də rə:Iz əmpy ðə brikən t $\Lambda$ nz

In blakmuər b(ə:)I ðə stə:uər

If ju: kud zi: ðər kımli gæit

ən pərrti fjesız smə:Ilz

วtripən pn sə lə:it ə wæit

ən stepən pf ðə stə:Ilz

əgwæIn tə t $\int$ ərrt $\int$ əz belz də swiy

ən rı̄ Iðın ðə tə:uər

jəd o:n ðə pə:rti mæidənz pljes

Iz blakmuər b(ə:)I ðə stəruər

If ju: vrəm wimbarn tok jər ro:d

to stə:uər or paləduər

ən a:l ðə fa:rmərz hə:uzən fo:d

ðər de:tərz ət ðə duər

juid krə:I tə batfələrz ət huəm

hiər k^m Iðın ən ə:uər

jəl və:In(d) ten mæidənz tə jər mə:In(d)

In blakmuər b(ə:)I ðə stə:uər

ən If jə lukt Iðın ðər duər

tə zi: əm in ðər pljes

ədu:ən hə:uswə:rk $\Lambda \mathrm{p}$ əvuər

ðər smə:Ilən m^ðərz fjes 
You'd cry- "Why, if a man would wive An' thrive, 'ithout a dow'r,

Then let en look en out a wife

let bim find bimself

In Blackmwore by the Stour."

As I upon my road did pass

A school-house back in Maÿ, There out upon the beäten grass

Wer maïdens at their plä̈;

An' as the pretty souls did tweil

toil

An' smile, I cried, “The flow'r

O' beauty, then, is still in bud

In Blackmwore by the Stour." 
jəd krə:I (h)wə:I If ə man wud wə:IV

ən Өrə:IV Iðə:ut ə dəruər

ðعn let ən luk ən əiut ə wə:If

In blakmuər b(ə:)I ðə stə:uər

əZ ə:I əppn mə:I ro:d did pa:s

ə skuilhə:us bak In mæI

ðعər ə:ut əppn ðə biətən gra:s

wər mæIdənz ət ðər plæI

ən az ðə pə:rti so:lz did twəril

ən smə:Il ə:I krə:Id ðə flə:uər

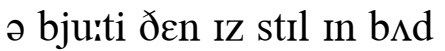

In blakmuər b(ə:)I ðə stə:uər 
'ITHIN the woodlands, flow'ry gleäded,

By the woak tree's mossy moot,

The sheenèn grass-bleädes, timber-sheäded, oak, stump shining

Now do quiver under voot;

An' birds do whissle over head, An' water's bubblèn in its bed, An' there vor me the apple tree

Do leän down low in Linden Lea.

When leaves that leätely wer a-springèn

Now do feäde 'ithin the copse, An' painted birds do hush their zingèn

Up upon the timber's tops;

An' brown-leav'd fruit's a-turnèn red,

In cloudless zunsheen, over head, sunsbine

Wi' fruit vor me, the apple tree

Do leän down low in Linden Lea.

Let other vo'k meäke money vaster

In the air o' dark-room'd towns, I don't dread a peevish meäster;

Though noo man do heed my frowns, I be free to goo abrode, out and about

Or teäke ageän my hwomeward road

To where, vor me, the apple tree

Do leän down low in Linden Lea. 


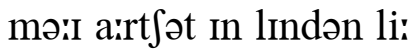

ıðın ðə (w)Udlən(d)z flə:uri gljedıd b(ə:)I ðə (w)uək tri:z mpsi mut

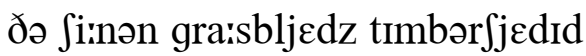
nə:u də kwivər $\Lambda$ ndər vut ən bə:rdz də (h)wisəl əivər hed ən wo:tərz bᄉblən in its bed ən ðعər vər mi: ði apəl tri: də liən dərun lo: in lindən li:

(h)wen liivz ðət ljetli wər əsprinən nə:u də fjed ıðın ðə kpps ən pæintıd bə:rdz də $\mathrm{h} \Lambda \int$ ðər zIngən $\Lambda p$ əppn ðə tımbərz tpps ən brə:unliivd fruits ətə:rnən red In klə:udlis z $\Lambda$ fiin orvər hed wi fruit vər mi: ði apəl tri: də liən də:un lo: in lindən li:

let $\Lambda$ ðr vo:k mjek m^ni va:stər In ði æIr ə da:rkru:md tə:unz ə:I do:nt dred ə piivis mjaistər ðo: nu: man də hi:d mə:I frə:unz ว:I bi: fri: to gu: əbro:d ar tjek əgjen mə: huəmwərd ro:d tə (h)weər vər mi: ði apəl tri: də liən də:un lo: in lindən li: 
AT peace day, who but we should goo

(In 1856 after the Crimean War)

To Caundle vor an' hour or two:

As gaÿ a day as ever broke

Above the heads o' Caundle vo'k,

folk

Vor peace, a-come vor all, did come

To them wi' two new friends at hwome.

Zoo while we kept, wi' nimble peäce,

The wold dun tow'r avore our feäce, pace

The aïr, at last, begun to come

Wi' drubbèns ov a beäten drum;

An' then we heärd the horns' loud droats throats

Plaÿ off a tuen's upper notes; tune's

An' then ageän a-risèn cheärm noise

Vrom tongues o' people in a zwarm:

An' zoo, at last, we stood among so

The merry feäces o' the drong. lane

An' there, wi' garlands all a-tied

In wreaths and bows on every zide,

An' color'd flags, a fluttrèn high

An' bright avore the sheenèn sky,

The very guide-post wer a-drest

shining

Wi' posies on his eärms an' breast. signpost

At last, the vo'k zwarm'd in by scores arms

An' hundreds droo the high barn-doors, folk

To dine on English feäre, in ranks, through

A-zot on chairs, or stools, or planks,

By bwoards a-reachèn, row an' row,

tables

Wi' cloths so white as driven snow.

An' while they took, wi' merry cheer,

Their pleäces at the meat an' beer,

The band did blow an' beät aloud

Their merry tuèns to the crowd; 
bIJəps ke:ndəl

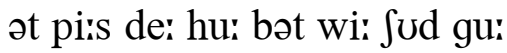

tə ke:ndəl vər ən əiuər ər tu:

əZ gæi ə de: əz عvər bro:k

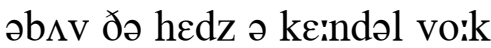

vər pi:s əkım vər a:l did kım

to ठعm wi tu: nju: fren(d)z ət huəm

zu: (h)wə:Il wi: kept wi nimbəl pjes

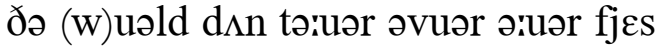

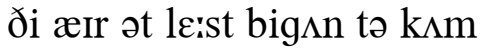

wi drıbənz əv ə biətən drım

ən ðعn wi: hiərd ðə ha:rnz lə:ud dro:ts

plæi pf ə tju:ənz $\Lambda$ pər no:ts

ən ðદn əgjen ə rə:Izən t $\int j a: r m$

vrəm t^yz ə pi:pəl In ə zwa:rm

ən zu: ət le:st wi: stud əmpy

ðə meri fjesız ə ðə droy

ən ठعər wi ga:rlən(d)z ail ətə:Id

In ri:ðz ən(d) bo:z pn evri zə:Id

ən kılərd flagz əfl $\Lambda$ trən hə:I

ən brə:It əvuər ðə Si:nən skə:I

ðə veri gə:Idpo:st wər ədrest

wi po:ziz pn (h)Iz ja:rmz on brest

at le:st ðə vo:k zwa:rmd in b(ə:)I skuərz

ən h^ndərdz dru: ðə hə:I ba:rnduərz

tə də:in pn inglif fjeər in rayks

əzat pn $\mathrm{t} \int \varepsilon \partial r z$ or stuilz or playks

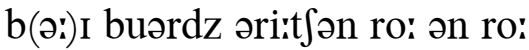

wi klpӨs sə (h)wə:It əz drIvən sno:

ən (h)wə:ıl ðe: tuk wi meri tfiər

ðər pljesız ət ðə mi:t ən biər

ðə ban(d) did blo: ən biət ələ:ud

ðər meri tju:ənz tə ðə krə:ud 
An' slowly-zwingèn flags did spread

Their hangèn colors over head.

An' then the vo'k, wi' jaÿ an' pride, folk, joy

Stood up in stillness, zide by zide,

Wi' downcast heads, the while their friend

Rose up avore the teäble's end,

An' zaid a timely greäce, an' blest

The welcome meat to every guest.

An' then arose a mingled naïse noise

O' knives an' pleätes, an' cups an' traÿs,

An' tongues wi' merry tongues a-drown'd

Below a deaf nèn storm o' sound.

An' zoo, at last, their worthy host

Stood up to gi'e em all a twoast,

That they did drink, wi' shouts o' glee,

An' whirlèn eärms to dree times dree.

An' when the bwoards at last wer beäre

Ov all the cloths an' goodly feäre,

An' froth noo longer rose to zwim

Within the beer-mugs sheenèn rim,

The vo'k, a-streamèn drough the door,

Went out to geämes they had in store.

An' on the blue-reäv'd waggon's bed,

Above his vower wheels o' red,

Musicians zot in rows, an' plaÿ'd

Their tuèns up to chap an' maïd,

That beät, wi' plaÿsome tooes an' heels,

The level ground in nimble reels.

An' zome ageän, a-zet in line,

An' startèn at a given sign,

Wi' outreach'd breast, a-breathèn quick

Droo op'nèn lips, did nearly kick

Their polls, a-runnèn sich a peäce,

with blue side-extensions

shining

folk, through

Wi' streamèn heäir, to win the reäce. 
ən slo:lizwinən flagz did spred

ðər hayən k^lərz ə:vər hed

ən ðعn ðə vo:k wi dzæ ən prə:Id

stud $\Lambda \mathrm{p}$ in strlnis zə:Id b(ə:) I zə:Id

wi də:unka:st hedz ðə (h)wə:Il ठər fren(d)

ro:z $\Lambda$ p əvuər ðə tjebəlz $\varepsilon n(d)$

ən zed ə tə:Imli grjes ən blest

ðə welkəm mi:t tu عvri gest

ən ðعn əro:z ə mingəld næIz

ə nə:IVZ ən pljets ən kıps ən træIz

ən t $\Lambda$ yz wi meri t $\Lambda \mathrm{yz}$ ədrə;und

bilo: ə defnən sta:rm ə sə:und

ən zu: ət le:st ðər wə:rði huəst

stud $\Lambda p$ to gi: əm a:l ə tuəst

ðət ðe: did drınk wi Səruts ə gli:

ən (h)wərr(d)lən ja:rmz tə dri: tə:Imz dri:

ən (h)wen ðə buərdz ət le:st wər bjeər

əv a:l ðə klpӨs ən gudli fjeər

on fro $\theta$ nu: lpygor ro:z to zwIm

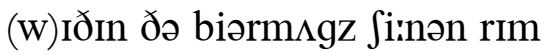

ðə vo:k əstri:mən dru: ðə duər

went ərut to gjemz ðe: had in stuər

ən pn ðə blu:rjevd wagənz bed

əb $\Lambda \mathrm{v}$ (h)Iz və:uər (h)willz ə red

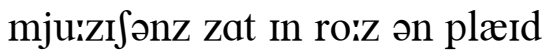

ठər tju:ənz $\Lambda p$ to t $\int a p$ ən mærd

ðət biət wi plæIsəm tuiz ən hi:lz

ðә levəl grə:un(d) in nimbəl ri:lz

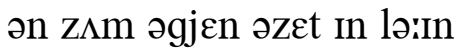

ən stairtən ət a givən sə:In

wi ə:utri:tft brest əbri:ðən kwık

dru: o:bnən lips did niərli kık

ðər po:lz ərınən sit $\int$ p pjes

wi stri:mən hjeər tə wIn ðə rjes 
An' in the house, an' on the green, An' in the shrubb'ry's leafy screen, On ev'ry zide we met sich lots O' smilèn friends in happy knots, That I do think, that drough the feäst through

In Caundle, vor a day at leäst,

You woudden vind a scowlèn feäce

Or dumpy heart in all the pleäce. 
ən In ðə hə:us ən pn ðə gri:n

ən In ðə $\int \mathrm{r} \Lambda$ briz li:fi skri:n

pn evri zə:Id wi: met sit lots

ə smə:Ilən fren(d)z in hapi nots

ðət ə:I də ठı̄k ðət dru: ðə fiəst

In ke:ndəl vər ə de: ət liəst

jə wudən və:In(d) ə skə:ulən fjes

ar d $\lrcorner$ mpi hairt In a:l ðə pljes 
Come by, an' cried, "Well done, zing on,

I thought as I come down the hill,

An' heärd your zongs a-ringèn sh'ill, tunefully

Who woudden like to come, an' fling

A peäir o' prongs where you did zing?”

J. Aye, aye, he woudden vind it plaÿ,

To work all day a-meäkèn haÿ,

Or pitchèn o't, to eärms a-spread

$i t$, arms

By lwoaders, yards above his head,

'T'ud meäke en wipe his drippèn brow.

A. Or else a-reäken after plow.

it would make him

J. Or workèn, wi' his nimble pick,

A-stiffled wi' the haÿ, at rick.

the wagon

A. Our Company would suit en best,

stifled

When we do teäke our bit o' rest,

At nunch, a-gather'd here below

bim

The sheäde theäse wide-bough'd woak do drow,

lunch

Where hissèn froth mid rise, an' float

this, oak, throw

In horns o' eäle, to wet his droat.

might

ale, throat

J. Aye, if his zwellèn han' could drag

A meat-slice vrom his dinner bag.

'T'ud meäke the busy little chap

it would

Look rather glum, to zee his lap

Wi' all his meal ov woone dry croust,

one, crust

An' vinny cheese so dry as doust. blue vinny (made from skimmed milk), dust 


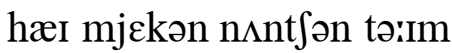

an ən dzan əte:kən o:t

A. bak hiər bət nə’u ðə dzpbər dzan

k $\Lambda \mathrm{m}$ bə:I ən krə:Id wel d $\Lambda$ z zIn pn

ə:I ðっ:t əZ ə:I k^m də:un ðə hıl

ən hiərd jər zpyz ərinən $\int \mathrm{Il}$

hu: wudən lə:ik to kım ən flin

ə pjeər ə proyz (h)wər ju: did zIn

J. æı æı hi: wudən və:In(d) It plæI

to wərk a:l de: əmjekən hæI

ar pitfən o:t to ja:rmz əspred

b(ə:)I luədərz jairdz əb $\Lambda \mathrm{v}$ (h)Iz hed

tud mjek ən wə:Ip (h)Iz dripən brə:u

A. ar عls ərjekən ع:tər plə:u

J. ar wə:rkən wi (h)Iz nImbəl prk

əstıfəld wi ðə hæı ət rrk

A. ə:uər kımpəni wud suit ən best

(h)wen wi: də tjek əiuər bit ə rest

ət nınt $\int$ əgaðərd hiər bilo:

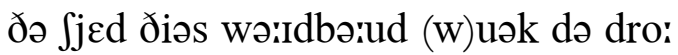

(h)wər hisən frp $\theta$ mid rə:Iz ən flo:t

In ha:rnz ə jel to wet (h)Iz dro:t

J. æI If (h)IZ zwelən han kud drag

ə mi:tslə:Is vrəm (h)Iz dinər bag

tud mjek ðə bizi litəl t $\int a p$

luk re:ðər glım to zi: (h)Iz lap

wi a:l (h)Iz mill əv (w)u:n drə:I krə:ust

ən vini tfi:z sə drə:ı əz də:ust 
A. Well, I don't grumble at my food,

'Tis wholesome, John, an' zoo 'tis good.

$\mathrm{J}$. Whose reäke is that a-lyèn there?

Do look a bit the woo'se vor wear.

worse

A. Oh! I mus' get the man to meäke

A tooth or two vor thik wold reäke, that old

'Tis leäbour lost to strik a stroke strike

Wi' him, wi' half his teeth a-broke. it, its

J. I should ha' thought your han' too fine

To break your reäke, if I broke mine.

A. The ramsclaws thin'd his wooden gum

creeping crowfoot, its

O' two teeth here, an' here were zome

That broke when I did reäke a patch

O' groun' wi' Jimmy, vor a match:

An' here's a gap ov woone or two

one

A-broke by Simon's clumsy shoe,

An' when I gi'ed his poll a poke,

gave, head

Vor better luck, another broke.

In what a veag have you a-swung

Your pick, though, John? His stem's a-sprung.

rage

its bandle's broken

J. When I an' Simon had a het

match

O’ pookèn, yonder, vor a bet,

at stacking bay in cones

The prongs o'n gi'ed a tump a poke,

its prongs gave a molehill

An' then I vound the stem a-broke,

But they do meäke the stems o' picks

O' stuff so brittle as a kicks.

stem of cow parsley 
A. wel ə:I do:nt gr $\wedge$ mbəl ət mə:I fud tız huəlsəm dzan ən zu: trz gud

J. hu:z rjek Iz ðat ələ:ın ðદər də luk ə bit ðə wu:s vər weər

A. o: ə:I $\mathrm{m} \Lambda \mathrm{s}$ get $\partial ə$ man tə mjek ə tu: $\theta$ ər tu: vər ðrk (w)uəld rjek tız ljebər lost to strik a stro:k wi hım wi he:f (h)Iz ti: $\theta$ əbro:k

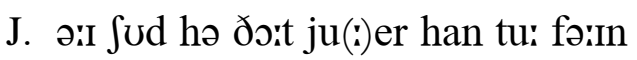
tə bre:k ju(:)er rjek If ə:I bro:k mə:In

A. ðə ramzkle:z ðınd (h)Iz wudən g $\Lambda \mathrm{m}$

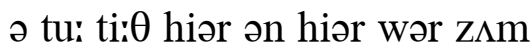
ðət bro:k (h)wen əII did rjek ə pat $\int$ a grəun wi dzımi vər ə mats ən hiərz ə gap əv (w)u:n ər tu: əbro:k b(ə:)I sə:Imənz klımzi fu: ən (h)wen ə:I gi:d (h)Iz po:l ə po:k

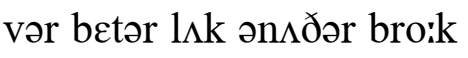
In (h)wDt a ve:g həv ju: əswıy ju(:)ər prk ðo: dzan (h)rz stemz əspr^y

J. (h)wen ə:I ən sə:Imən had ə het ə pukən jandər vər ə bet ðə pronz o:n giid ə t $\wedge$ mp ə po:k ən ठદn ə:I və:un(d) ðə stem əbro:k bət ðe: də mjek ðə stemz ə piks ə st $\Lambda$ f sə britəl əz ə kiks 
A. There's poor wold Jeäne, wi' wrinkled skin,

A-tellèn, wi' her peakèd chin,

Zome teäle ov her young days, poor soul.

Do meäke the young-woones smile. 'Tis droll.

What is it? Stop, an' let's goo near.

I do like theäse wold teäles. Let's hear.

these old 

A. ठərz pu(:)ər (w)uəld dzjen wi rinkəld skın ətclən wi (h)ər pi:kid t $\int$ In
$\mathrm{z} \Lambda \mathrm{m}$ tjel əv (h)ər j^y de:z pu(:)ər so:l
də mjєk ðə j^y (w)u:nz smə:Il tız dro:l
(h)wpt Iz It stpp ən lets gu: niər
ə:I du: lə:ık ðiəz (w)uəld tjelz lets hiər 


\section{A FATHER OUT, AN' MOTHER HWOME}

THE snow-white clouds did float on high

In shoals avore the sheenèn sky, shining

An' runnèn weäves in pon' did cheäse

pond, chase

Each other on the water's feäce,

As hufflèn win' did blow between

gusty

The new-leav'd boughs o' sheenèn green.

An' there, the while I walked along

The path, drough leäze, above the drong,

A little maïd, wi' bloomèn feäce,

Went on up hill wi' nimble peäce,

A-leänèn to the right-han' zide,

To car a basket that did ride,

carry

A-hangèn down, wi' all his heft, weight

Upon her elbow at her left.

An' yet she hardly seem'd to bruise

The grass-bleädes wi' her tiny shoes,

That pass'd each other, left an' right,

In steps a'most too quick vor zight.

But she'd a-left her mother's door

A-bearèn vrom her little store

Her father's welcome bit o' food,

Where he wer out at work in wood;

An' she wer bless'd wi' mwore than zwome-

A father out, an' mother hwome.

An' there, a-vell'd 'ithin the copse,

Below the timber's new-leav'd tops,

Wer ashen poles, a-castèn straïght,

ash-wood

On primrwose beds, their langthy waight;

Below the yollow light, a-shed

Drough boughs upon the vi'let's head,

through

By climèn ivy, that did reach,

A sheenèn roun' the dead-leav'd beech.

shining 
ə fع:ðər ə:ut ən $\mathrm{m} \wedge$ ðə huəm

ðə sno:(h)wə:It klə:udz did flo:t pn hə:I

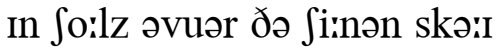

ən r $\Lambda$ nən wjevz in ppn did $\mathrm{t} \int \varepsilon s$

i:t $\Lambda$ ðər pn ðə wə:tərz fjes

əz h^flən win(d) did blo: bitwi:n

ðə njuili:vd bə:uz ə Jiinən gri:n

ən ðعər ðə (h)wə:Il ə:I we:kt əlpy

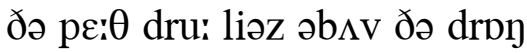

ə litəl mæid wi bluimən fjes

went pn $\Lambda$ p hil wi nimbəl pjes

əliənən tə ðə rə:Ithan zə:Id

to ka:r ə ba:skit ðət did rə:Id

əhayən də:un wi a:l (h)Iz heft

əppn (h)ər عlbo: ət (h)ər left

on i:t fi: harrdli si(:)md to bru:z

ðə gra:sbljedz wi (h)ər tə:Ini Ju:z

ðət pa:st iit $\Lambda$ ðər left ən rə:it

In steps a:məst tu: kwik vər zə:It

bət fiid əleft (h)ər m^ðərz duər

əbeərən vrəm (h)ər litəl stuər

(h)ər fe:ðərz welkəm bit ə fud

(h)wər hi: wər ə:ut ət wərrk in wud

ən Ji: wər blest wi muər ðən zムm

ə fe:ðər ə:ut ən $\mathrm{m} \Lambda$ ðə huəm

ən ðعər əvعld IðIn ðə kpps

bılo: ðə tımbərz nju:liivd tpps

wər a $\int ə n$ po:lz əkaistən stræit

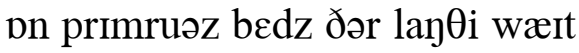

bilo: ðə jalər lə:it $ə \int \varepsilon d$

dru: bə:uz əppn ðə vərIləts hed

b(ə:)I klımən ə:IVi ðət did ritt

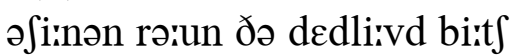


An' there her father zot, an' meäde

His hwomely meal bezide a gleäde;

While she, a-croopèn down to ground,

stooping

Did pull the flowers, where she vound

The droopèn vi'let out in blooth,

Or yollow primrwose in the lewth,

That she mid car em proudly back,

An' zet em on her mother's tack;

bloom

shelter

might carry

shelf

Vor she wer bless'd wi' mwore than zwome-

A father out, an' mother hwome.

A father out, an' mother hwome,

Be blessèns soon a-lost by zome;

A-lost by me, an' zoo I praÿ'd

so

They mid be speär'd the little maïd.

might, spared 
ən ðعər (h)ər fє:ðər zat ən mjed

(h)Iz huəmli mi:l bızə:Id ə gljed

(h)wə:Il fi: əkru:pən də:un tə grə:un(d)

did pul ðə flə:uərz (h)wər $\int i$ ii və:un(d)

ðə dru:pən və:Ilət ə:ut in blu: $\theta$

ər jalər primruəz In ðə lu: $\theta$

ðət $\int i$ i: mId ka:r əm prə:udli bak

ən zet əm pn (h)ər m^ðərz tak

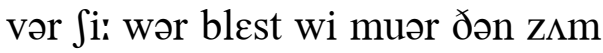

ə fє:ðər ə:ut ən $\mathrm{m} \Lambda$ ðr huəm

ə fє:ðər ə:ut ən $\mathrm{m} \Lambda$ ðə huəm

bi: blesənz su:n əlpst b(ə:)I Zムm

əlpst b(ə:)I mi: ən zu: ə:I præId

ðе: mId bi: speərd ðə litəl mæId 


\section{RIDDLES}

Anne an' Joey a-ta'ken.

talking

A. A plague! theäse cow wont stand a bit, this

Noo sooner do she zee me zit

Ageän her, than she's in a trot,

A-runnèn to zome other spot.

J. Why 'tis the dog do sceäre the cow,

He worried her a-vield benow.

just now

A. Goo in, Ah! Liplap, where's your tail!

J. He's off; then up athirt the rail.

across

Your cow there, Anne's a-come to hand

A goodish milcher. A. If she'd stand,

milking cow

But then she'll steäre an' start wi' fright

To zee a dumbledore in flight.

bumble-bee

Last week she het the pail a flought,

blow

An' flung my meal o' milk half out.

J. Ha! Ha! But Anny, here, what lout

Broke half your small pail's bottom out?

A. What lout indeed! What, do ye own

The neäme? What dropp'd en on a stwone?

J. Hee! Hee! Well now he's out o' trim

Wi' only half a bottom to en;

it

Could you still vill en' to the brim

An' yit not let the milk run drough en?

through 
ridəlz

an ən dzo:i ətع:kən

A. ə pljeg ðiəs kə:u wu(:)nt $\operatorname{stan}(\mathrm{d})$ ə bit nu: su:nər də Ji: zi: mi: zit əgjen hər ठən Siiz In ə trpt

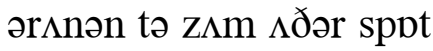

J. (h)wə:I tız ðə dpg də skjeər ðə kə‘u hi: warid (h)ər əvi:l(d) binə:u

A. gu: in a: liplap (h)wərz jər tæil

J. hi:z pf ðعn $\Lambda$ p əðə:rt ðə ræıl ju(:)ər kə:u ठعər anz əkım to han(d) ə gudis miltfor A. If $\int i: d \operatorname{stan}(d)$ bət ðعn Ji:l stjeər ən sta:rt wi frə:It to zi: ə d $\Lambda$ mbəlduər in flə:it 1ع:st wi(:)k fii het ðə pæil ə flə:ut ən flıy mə:I mi:l ə milk he:f ə:ut

J. ha: ha: bət ani hiər (h)wot lə:ut bro:k he:f jər sma:l pæilz bptəm əsut

A. (h)wpt ləuut Indi:d (h)wpt du: i: o:n ðə njem (h)wpt drapt ən pn ə stuən

J. hi: hi: wel nə:u hi:z ərut ə trim wi o:nli he:f ə botəm tu: ən kud jə stıl vil ən tə ðə brim ən i:t not let ðə milk rın dru: ən 
A. Aye, as for nonsense, Joe, your head

Do hold it all so tight's a blather,

But if 'tis any good, do shed

It all so leäky as a lather.

ladder

Could you vill pails 'ithout a bottom,

Yourself that be so deeply skill'd?

J. Well, ees, I could, if I'd a-got em

Inside o' bigger woones a-vill'd.

ones

A. La! that is zome'hat vor to hatch!

Here answer me theäse little catch.

Down under water an' o' top o't

think up

this, riddle

of it

I went, an' didden touch a drop o't.

$J$. Not when at mowèn time I took

An' pull'd ye out o' Longmeäd brook,

Where you'd a-slidder'd down the edge

An' zunk knee-deep bezide the zedge,

A-tryèn to reäke out a clote.

yellow water-lily

A. Aye I do hear your chucklèn droat.

throat

When I athirt the brudge did bring

across

Zome water on my head vrom spring,

Then under water an' o' top o't

Wer I an' didden touch a drop o't.

J. O Lauk! What thik wold riddle still,

Lord, that old

Why that's as wold as Duncliffe Hill;

old

“A two-lagg'd thing do run avore

An' run behind a man,

An' never run upon his lags

Though on his lags do stan'." 
A. æI az vər npnsəns dzo: ju(:)ər hed də huəld it a:l sə tə:its ə blaðər bət If tIz عni gud də $\int \varepsilon d$ It a:l sə li:ki əz ə laðər kud ju: vil pæilz Iðə:ut ə bptəm jərzıf ðət bi: sə di:pli skıld

J. wel iss ə:I kud If ə:Id əgpt əm Insə:Id ə bigər (w)uinz əvild

A. la ðat Iz z^mət vər to hat hiər ع:nsər mi: ðiəs litəl kat dərun $\Lambda$ ndər wo:tər an ə top o:t ə:I went ən didən t $\Lambda \mathrm{t} \int$ ə drap o:t

J. ndt (h)wen ət mo:ən tə:Im ə:I tuk ən puld i: əuut ə lpymiəd bruk (h)wər ju:d əslidərd də:un ði $\varepsilon d 3$ ən z^yk ni:di:p bızə:Id ðə zed3 ətrə:ı⿰n tə rjek ərut ə klo:t

A. æI ə:I də hiər jər $\mathrm{t} \int \Lambda$ klən dro:t (h)wen ə:I əðə:rt ðə brıdz did brin z^m wo:tər pn mə:I hed vrəm sprin ðعn $\Lambda$ ndər wo:tər an ə tpp o:t wər ə:I ən didən $\mathrm{t} \Lambda \mathrm{t} \int$ ə drap o:t

J. o: lo:k (h)wpt ðık (w)uəld ridəl stıl (h)wə:I ðats əz (w)uəld əz d $\Lambda$ nklıf hıl ə tu:lagd ðin də r $\Lambda$ n əvuər ən r $\Lambda$ bihə:In(d) ə man ən nevər r $\wedge$ n əppn (h)Iz lagz ðo: pn (h)rz lagz də stan 
What's that?

I don't think you do know.

There idden sich a thing to show.

isn't

Not know? Why yonder by the stall

'S a wheel-barrow bezide the wall,

Don't he stand on his lags so trim,

An' run on nothèn but his wheels wold rim.

old

A. There's horn vor Goodman's eye-zight seäke;

There's horn vor Goodman's mouth to teäke;

There's horn vor Goodman's ears, as well

As horn vor Goodman's nose to smell-

What horns be they, then? Do your hat

Hold wit enough to tell us that?

J. Oh! horns! but no, I'll tell ye what,

My cow is hornless, an' she's knot.

hornless

A. Horn vor the mouth's a hornen cup.

J. An' eäle 's good stuff to vill en up.

ale, it

A. An' horn vor eyes is horn vor light,

Vrom Goodman's lantern after night;

Horn vor the ears is woone to sound

Vor hunters out wi' ho'se an' hound;

borse

But horn that vo'k do buy to smell o'

folk

Is hart's-horn. J. Is it? What d'ye tell o'

How proud we be, vor ben't we smart?

Aye, horn is horm, an' hart is hart.

Well here then, Anne, while we be at it,

'S a ball vor you if you can bat it. 
(h)wpts ðat

ə:I do:nt ðınk ju: də no:

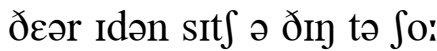

npt no: (h)wə:I jandər b(ə:)I ðə sta:l

z ə (h)willbarə bizə:Id ðə wa:l

do:nt hi: $\operatorname{stan}(\mathrm{d})$ pn (h)Iz lagz sə trim

ən rın pn $n \Lambda \theta$ ən bət (h)Iz (h)willz (w)uəld rim

A. ðərz ha:rn vər gudmənz ə:Izə:It sjek ðərz ha:rn vər gudmənz mə:u $\theta$ to tjek ðərz ha:rn vər gudmənz iərz əz wel əz ha:rn vər gudmənz no:z to smel (h)wpt ha:rnz bi: ðe: ðعn də jər hat huold wit in $\Lambda$ f tə tel əs ðat

J. o: ha:rnz bət no: ə:Il tel i: (h)wpt mə:I kə‘u Iz ha:rnlıs ən Ji:z npt

A. ha:rn vər ðə mə:uӨs ə ha:rnən kıp

J. ən jelz gud st $\Lambda$ f tə vil ən $\Lambda p$

A. ən ha:rn vər ə:Iz Iz ha:rn vər lə:It vrəm gudmənz lantərn e:tər nə:It ha:rn vər ði iərz IZ (w)u:n tə sə:un(d) vər h^ntərz ə;ut wi hps ən hə:un(d) bət ha:rn ðət vo:k də bə:I tə smel o Iz ha:rtsha:rn J. IZ It (h)wpt dji: tel o hə:u prə:ud wi: bi: vər be:nt wi: smairt æı ha:rn Iz ha:rn ən ha:rt Iz ha:rt wel hiər ðعn an (h)wə:il wi: bi: at it s a ba:l vər ju: If jə kən bat it 
On dree-lags, two-lags, by the zide

O' vower-lags, woonce did zit wi' pride,

three-legs

When vower-lags, that velt a prick,

Vrom zix-lags, het two lags a kick.

four-legs once

An' two an' dree-lags vell, all vive,

Slap down, zome dead an' zome alive.

A. Teeh! heeh! what have ye now then, Joe,

At last, to meäke a riddle o'?

J. Your dree-lagg'd stool woone night did bear

one

Up you a milkèn wi' a peäir;

An' there a zix-lagg'd stout did prick

bit (i.e. gave)

Your vow'r-lagg'd cow, an meäke her kick,

A-hettèn, wi' a pretty pat,

Your stool an' you so flat's a mat.

You scrambled up a little dirty,

But I do hope it didden hurt ye.

didn't

A. You hope, indeed! a likely ceäse,

Wi' thik broad grin athirt your feäce.

that, across

You saucy good-vor-nothèn chap,

I'll gi'e your grinnèn feäce a slap, give

Your drawlèn tongue can only run

To turn a body into fun.

J. Oh! I woont do 't ageän. Oh dear!

Till next time, Anny. Oh my ear!

Oh! Anne, why you've a-het my hat

'Ithin the milk, now look at that.

into

A. Do sar ye right, then, I don't ceäre.

I'll thump your noddle,- - there- - there- there. 
pn dri:lagz tu:lagz b(ə:)I ðə zə:Id ə və:uərlagz (w)u:ns did zit wi prə:Id (h)wen və:uərlagz ðət velt ə prik vrəm zikslagz het tu: lagz ə kık on tu: on dri:lagz vel a:l və:Iv slap də:un zım ded ən zım ələ:IV

A. ti: hi: (h)wpt həv i: nə:u ðعn dzo: at le:st to mjek ə ridəl o

J. jər drillagd stu:l (w)u:n nə:it did beər $\Lambda$ p ju: ə milkən wi a pjeər ən ðعər ə zıkslagd stərut did prik jər və'uərlagd kə‘u ən mjek (h)ər kık əhetən wi ə pərrti pat jər stu:l ən ju: sə flats ə mat jə skrambəld $\Lambda \mathrm{p}$ ə litəl də:rti bət ə:I də ho:p it didən hərrt i:

A. ju: ho:p Indi:d ə lə:ıkli kjes wi ðık bro:d grın əðə:rt jər fjes jə sa:si gudvərn $\wedge$ Өən tfap ə:Il gi: jər grinən fjes ə slap jər dre:lən t $\Lambda$ 引 kən o:nli r $\wedge n$ to tə:rn ə bodi intə f $\wedge$ n

J. o: ə:I wu(:)nt du: $\mathrm{t}$ əgjen o: diər tıl neks(t) tə:Im ani o: mə:I iər o: an (h)wə:I jəv əhet mə:I hat ıðın ðə milk nə:u luk ət ðat

A. də sa:r i: rə:It ðعn ə:I do:nt kjeər

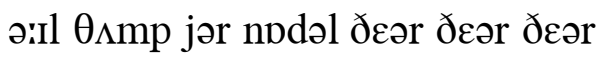


AND oh! the jaÿ our rest did yield, joy

At evenèn by the mossy wall,

When we'd a-work'd all day a-vield,

While zummer zuns did rise an' vall,

As there a-lettèn

Goo all frettèn,

An' vorgettèn all our tweils,

toils

We zot among our childern's smiles.

sat

An' under skies that glitter'd white,

The while our smoke, arisèn blue,

Did melt in aiër, out o' zight,

Above the trees that kept us lew,

sheltered

Wer birds a-zingèn,

Tongues a-ringèn,

Childern springèn, vull o' jaÿ,

A-finishèn the day in plaÿ.

An' back behind, a-stannèn tall,

The cliff did sheen to western light;

standing

shine

An' while avore the water-vall,

A-rottlèn loud, an' foamèn white,

The leaves did quiver,

Gnots did whiver,

gnats, hover

By the river, where the pool,

In evenèn aïr did glissen cool.

An' childern there, a-runnèn wide,

Did plaÿ their geämes along the grove,

Vor though to us 'twer jaÿ to bide

At rest, to them 'twer jaÿ to move. 
de:z wərrk əd $\Lambda$ n

ən(d) o: ठə dzæi ə:uər rest did ji:l(d)

ət iivmən b(ə:) I ðə mpsi wa:l

(h)wen wi:d əwə:rkt a:l de: əvi:l(d)

(h)wə:Il zımər z^nz did rə:Iz ən va:l

əz ðعər əletən

gu: a:l fretən

ən vərgetən a:l ə:uər twə:Ilz

wi: zat əmpy ə:uər tfildərnz smə:Ilz

ən $\Lambda$ ndər skə:Iz ðət glitərd (h)wə:It

ðə (h)wə:Il ə:uər smo:k ərə:Izən blu:

did melt in æiər əiut ə zə:It

əb $\Lambda$ v ðə tri:z ðət kept əs lu:

wər bə:rdz əzingən

t $\wedge$ yz әrinən

t $\int$ Ildərn sprinən vul ə dzæI

əfınIfən ðə de: In plæI

ən bak bihə:In(d) əstanən ta:l

ðə klıf did fin to westərn lə:It

ən (h)wə:Il əvuər ðə wə:tərva:l

ərptlən lə:ud ən fo:mən (h)wə:It

ðə liivz did kwivər

nats did (h)wivər

b(ə:)I ðə rIvər (h)wər ðə pu:l

In i:vmən ærr did glisən ku:l

ən t $\mathrm{f}$ Ildərn ठعər ərınən wə:Id

did plæı ðər gjemz əlpy ðə gro:v

vər ðo: tu $\Lambda$ s twər dzæi tə bə:Id

at rest to ठعm twər dzæI to mo:v 
The while my smilèn

Jeäne, beguilèn,

All my tweilèn, wi' her ceäre,

toiling

Did call me to my evenèn feäre.

fare (meal) 
ðə (h)wə:Il mə:I smə:Ilən

dzjen bigərilən

a:l mə:I twə:Ilən wi (h)ər kjeər

did ka:l mi: to mə:I i:vmən fjeər 


\section{LIGHT OR SHEÄDE}

A Maÿtide's evenèn wer a-dyèn,

Under moonsheen, into night,

moonshine

Wi' a streamèn wind a-sighèn

By the thorns a-bloomèn white.

Where in sheäde, a-zinkèn deeply,

Wer a nook, all dark but lew,

sheltered

By a bank, arisèn steeply,

Not to let the win' come drough.

through

Should my love goo out, a-showèn

All her smiles, in open light;

Or, in lewth, wi' wind a-blowèn,

shelter

Staÿ in darkness, dim to zight?

Staÿ in sheäde o' bank or wallèn,

walls

In the warmth, if not in light;

Words alwone vrom her a-vallèn,

falling

Would be jay vor all the night.

joy 
lə:It ar $\int j \varepsilon d$

ə mæitə:Idz i:vmən wər ədə:ıวn

$\Lambda$ ndər mu:n $\int i$ in intə nə:it

wi ə stri:mən win(d) əsə:Iən

b(ə:)I ðə ða:rnz əblu:mən (h)wə:It

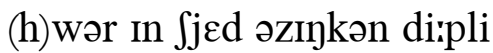

wər ə nuk a:l da:rk bət lu:

b(ə:)I ə bayk ərə:Izən sti:pli

not tə let ठə win(d) kım dru:

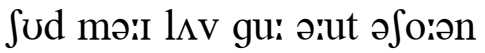
a:l (h)ər smə:Ilz in o:bən lə:it ar in lu: $\theta$ wi win(d) əblo:ən stæı in da:rknis dim to zə:It stæI In Jjed ə bayk ər wa:lən In ठə wa:rm $\theta$ If npt in lə:It wə:rdz əluən vrəm hə:r əva:lən wud bi: dzæI vər a:l ðə nə:It 
(1) WELL, here we be, then, wi' the vu'st poor lwoad

(2) The road, George, no. There's na'r a road. That's wrong. never a If we'd a road, we mid ha' got along. might

(1) Noo road! Ees 'tis, the road that we do goo. yes

(2) Do goo, George, no. The pleäce we can’t get drough. through

(1) Well, there, the vu'st lwoad we 've a-haul'd to day

Is here a-stoodèd in theäse bed o' clay.

Here's rotten groun'! an' how the wheels do cut! The little woone's a-zunk up to the nut. one's

(3) An' yeet this rotten groun' don't reach a lug. yet, is no bigger than

(1) Well, come, then, gi'e the plow another tug. a pole (5 $\frac{1}{2}$ yards)

(2) They meäres wull never pull the waggon out, horses A-lwoaded, an' a-stoodèd in thik rout. that rut

(3) We'll try. Come, Smiler, come! C' up, Whitevoot, gee!

(2) White-voot wi' lags all over mud! Hee! Hee!

(3) 'Twoon't wag. We shall but snap our gear, move An' overstraïn the meäres. 'Twoon't wag, 'tis clear. 
ðə wagən əstudid

dri: o:m ətع:kən o:t

(1) wel hiər wi: bi: ðعn wi ðə vıst pu(:)ər luəd ə vıZ wi: bro:t əstudid In ðə ro:d

(2) ðә ro:d dza:rd3 no: ðərz nar ə ro:d ðats roy If wi:d ə ro:d wi: mid hə gpt əlpy

(1) nu: ro:d its tız ðə ro:d ðət wi: də gu:

(2) də gu: dzaird3 no: ðə pljes wi: ke:nt get dru:

(1) wel ðعər ðə vıst luəd wi:v əha:ld tə de:

Iz hiər əstudid in ðiəs bed ə kle:

hiərz rotən grə:un ən hə:u ðə (h)willz də k $\Lambda \mathrm{t}$

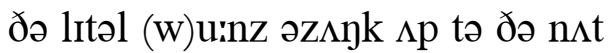

(3) ən (j)itt ðIs rotən grə:un do:nt ritt ə $1 \wedge g$

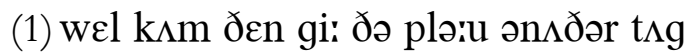

(2) ðе: mjeərz wul nevər pul ðə wagən ə:ut əluədid ən əstudid In ðrk rə氵ut

(3) wi:l trə:I kım smə:Ilər kım kıp (h)wə:Itvut dzi:

(2) (h)wə:ttvut wi lagz a:l o:vər mıd hi: hi:

(3) twu(:)nt wag wi: Səl bət snap ə'uər giər ən ə:vərstræın ðə mjeərz twu(:)nt wag tız kliər 
(1) That's your work, William. No, in coo'se, 'twoon't wag. of course Why did ye drēve en into theäse here quag? drive it, this, bog The vore-wheels be a-zunk above the nuts.

(3) What then? I coulden leäve the beäten track, To turn the waggon over on the back

Ov woone o' theäsem wheel-high emmet-butts. If you be sich a drēver, an' do know't, one, these, ant-hills You drēve the plow, then; but you'll overdrow 't. driver wagon, turn it over

(1) I drēve the plow, indeed! Oh! ees, what, now The wheels woont wag, then, I mid drēve the plow! yes We'd better dig away the groun' below

The wheels. (2) There's na'r a speäde to dig wi'.

never a

(1) An' teäke an' cut a lock o' frith, an' drow brushwood, throw it Upon the clay. (2) Nor hook to cut a twig wi'.

(1) Oh! here's a bwoy a-comèn. Here, my lad, Dost know vor a'r a speäde, that can be had? ever a

(B) At father's. (1) Well, where's that? (B) At Sam'el Riddick's.

(1) Well run, an' ax vor woone. Fling up your heels, An' mind: a speäde to dig out theäsem wheels, An' hook to cut a little lock o' widdicks. ask, one
these
brushwood

(3) Why, we shall want zix ho'ses, or a dozen, horses To pull the waggon out, wi' all theäse vuzzen. this furze (gorse)

(1) Well, we mus' lighten en; come, Jeämes, then, hop it Upon the lwoad, an' jus' fling off the top. 
(1) ðats ju(:)ər wərk wiləm no: in ku:s twu(:)nt wag

(h)wə:I did i: dre:v ən Intə ðiəs hiər kwag

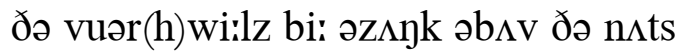

(3) (h)wpt ðعn ə:I kudən liəv ðə biətən trak

to tə:rn ðə wagən ə:vər pn ðə bak

əv (w)u:n ə ठiəzəm (h)willhə:I emətbıts

If ju: bi: sit $\int$ a dre:vər ən də no:t

ju: dre:v ðə plə:u ðعn bət ju:l ə:vərdro:t

(1) ə:I dre:v ðə plə:u Indi:d o: iss (h)wpt nə:u

ðə (h)wi:lz wu(:)nt wag ðعn ə:I mId dre:v ðə plə:u

wi:d betər dig əwə:ı ðə grə:un bilo:

ðə (h)wi:lz (2) ðərz nar ə spjed tə dıg wi

(1) ən tjek ən kıt ə lpk ə fri $\theta$ ən dro:

əppn ðə kle: (2) nar huk tə kıt ə twig wi

(1) o: hiərz ə bwə:I əkımən hiər mə:I lad dəst no: vər ar ə spjed ðət kən bi: had

(B) ət fe:ðərz (1) wel (h)wərz ðat (B) ət saməl ridiks

(1) wel r $\wedge$ n ən a:ks vər (w)u:n flın $\Lambda$ p jər hi:lz

ən mə:In(d) ə spjed tə dig ə:ut ðiəzəm (h)wi:lz

ən huk to kıt ə litəl lok ə widiks

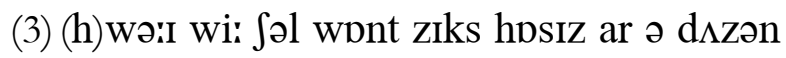

tə pul ðə wagən ə:ut wi a:l ðiəz vızən

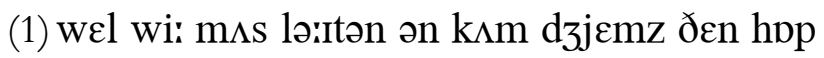

əppn ðə luəd ən $\mathrm{d}_{3} \Lambda \mathrm{s}$ flin pf ðə tpp 
(2) If I can clim' en; but 'tis my consait,

That I shall overzet en wi' my waïght.

(1) You overzet en! No, Jeämes, he won't vall, it The lwoad's a-built so firm as any wall.

(2) Here! lend a hand or shoulder vor my knee

Or voot. I'll scramble to the top an' zee

What I can do. Well, here I be, among

The fakkets, vor a bit, but not vor long. faggots

Heigh, George! Ha! ha! Why this wull never stand.

Your firm 's a wall, is all so loose as zand;

'Tis all a-come to pieces. Oh! Teäke ceäre!

Ho! I'm a-vallèn, vuzz an' all! Haë! There!

falling, furze

(1) Lo'k there, thik fellor is a-vell lik' lead, An' half the fuzzen wi 'n, heels over head! There's all the vuzz a-lyèn lik' a staddle, An' he a-deäb'd wi' mud. Oh! Here's a caddle! look, that, fallen furze with bim haystack-base covered, muddle

(3) An’ zoo you soon got down zome vuzzen, Jimmy. so

(2) Ees, I do know 'tis down, I brought it wi' me. yes

(3) Your lwoad, George, wer a rather slick-built thing, easilyBut there, 'twer prickly vor the hands! Did sting?

(1) Oh! ees, d'ye teäke me vor a nincompoop, No, no. The lwoad wer up so firm 's a rock, But two o' theäsem emmet-butts would knock these ant-bills The tightest barrel nearly out o' hoop. 
(2) If ə:I kən klim ən bət tIZ mə:I kənsæit ðət ə:I Səl ə:vərzet ən wi mə:I wæit

(1) ju: o:vərzet ən no: dzjemz hi: wu(:)nt va:l ðə luədz əbılt sə fə:rm əz عni wa:l

(2) hiər $\operatorname{len}(\mathrm{d})$ ə han(d) ər fo:ldər vər mə:ı ni: ər vut əril skrambəl tə ðə tpp ən zi:

(h)wpt ə:I kən du: wel hiər ə:I bi: əmpy ðə fakəts vər a bit bət not vər lpy hæI dza:rd3 a: a: (h)wə:I ðIs wul nevər stan(d) ju(:)ər fə:rmz ə wa:l Iz a:l sə lu:s əz zan(d) tIz a:l əkım tə pissız o: tjek kjeər o: ə:Im əva:lən v $\Lambda z$ ən a:l hæı ðعər

(1) luk ðعər ðık felər IZ əvel lik led ən he:f ðə vızən wi (ə)n hi:lz ə:vər hed ðərz a:l ðə vız ələ:ıən lik ə stadəl ən hi: ədjebd wi mıd o: hiərz ə kadəl

(3) ən zu: jə su:n gpt də:un z^m vızən dzImi

(2) i:s ə:I də no: tız də:un ə:I bro:t it wi mi:

(3) ju(:)ər luəd dza:rd3 wər ə re:ðər slikbılt ðı bət ðعər twər prikli vər ðə han(d)z did stın

(1) o: iss dji tjek mi: vər ə ninkəmpu:p no: no: ðə luəd wər $\Lambda \mathrm{p}$ sə fərrmz ə rok bət tu: ə ठiəzəm عmətb $\Lambda$ ts wud nok ðə tə:Itıst barəl niərli ə:ut ə hu:p 
(3) Oh! now then, here 's the bwoy a-bringèn back

The speäde. Well done, my man. That idder slack.

isn't

(2) Well done, my lad, sha't have a ho'se to ride

When thou'st a meäre. (B) Next never's-tide.

never ever

(3) Now let's dig out a spit or two

spade's depth

O' clay, a-vore the little wheels;

Oh! so's, I can't pull up my heels,

I be a-stogg'd up over shoe.

souls (friends)

bogged

(1) Come, William, dig away! Why you do spuddle

work feebly

A'most so weak's a child. How you do muddle!

Gi'e me the speäde a-bit. A pig would rout

give

It out a'most so nimbly wi' his snout.

(3) Oh! so's, d'ye hear it, then. How we can thunder!

How big we be, then George! what next I wonder?

(1) Now, William, gi'e the waggon woone mwore twitch,

one

The wheels be free, an' 'tis a lighter nitch.

load

(3) Come, Smiler, gee! C’up, White-voot. (1) That wull do.

(2) Do wag. (1) Do goo at last. (3) Well done. 'Tis drough. move, through

(1) Now, William, till you have mwore ho'ses' lags,

Don't drēve the waggon into theäsem quags.

drive, these bogs

(3) You build your lwoads up tight enough to ride.

(1) I can't do less, d'ye know, wi' you vor guide. 
(3) o: nə:u ðعn hiərz ðə bwə:I əbrinən bak ðə spjed wel d $\Lambda$ n mə:I man ðat Idər slak

(2) wel d $\Lambda$ n mə:I lad Jat hav ə hps tə rə:Id

(h)wen ठə:ust ə mjeər (B) neks(t) nevərztə:Id

(3) nə:u lets dig ə:ut ə spit ər tu:

ə kle: əvuər ðə litəl (h)wi:lz

o: so:z ə:I ke:nt pul $\Lambda$ p mə:I hi:lz

ə:I bi: əstpgd $\Lambda$ p oivər $\int u$ :

(1) kım wiləm dig əwə:I (h)wə:I ju: də sp^dəl a:məst sə wi:ks ə t $\int ə: I l(d)$ hə:u jə də m^dəl gi: mi: ðə spjed əbit ə pig wud rə:ut It ərut a:məst sə nImbli wi (h)Iz snərut

(3) o: so:z dji: hiər it ðen hə:u wi: kən $\theta \Lambda$ ndər hə:u bıg wi: bi: ðعn dza:rd3 (h)wot neks(t) ə:I wındər

(1) nə:u wiləm gi: ðə wagən (w)u:n muər twit ठə (h)wi:lz bi: fri: ən tIz ə lə:itər nit

(3) kım smə:Ilər d3i: kıp (h)wə:Itvut (1) ðat wul du:

(2) də wag (1) də gu: ət le:st (3) wel d $\Lambda$ n tız dru:

(1) nə:u wiləm til ju: hav muər hpsiz lagz do:nt dre:v ðə wagən Intə ðiəzəm kwagz

(3) ju: bild jər luədz $\Lambda p$ tə:It in $\Lambda$ f tə rə:Id

(1) ə:I ke:nt du: les dji: no: wi ju: vər gə:Id 
WHILE zuns do roll vrom east to west

To bring us work, or leäve us rest,

There down below the steep hill-zide,

Drough time an' tide, the spring do flow;

through

An' mothers there, vor years a-gone,

Lik' daughters now a-comèn on,

To bloom when they be weak an' wan,

Went down the steps vor water.

An' what do yonder ringers tell

A-ringèn changes, bell by bell;

Or what's a-show'd by yonder zight

O' vo'k in white, upon the road, folk

But that by John o' Woodleys zide,

There 's now a-blushèn vor his bride,

A pretty maïd that vu'st he spied,

Gwain down the steps vor water.

going

Though she, 'tis true, is feäir an' kind,

There still be mwore a-left behind;

So cleän 's the light the zun do gi'e,

So sprack's a bee when zummer's bright;

An' if I've luck, I woont be slow

To teäke off woone that I do know,

A-trippèn gaily to an' fro,

Upon the steps vor water.

Her father idden poor-but vew

isn't, few

In parish be so well to do;

Vor his own cows do swing their tails

Behind his pails, below his boughs: 
gwæin də:un ðə steps vər wə:tər

(h)wə:Il z^nz də ro:l vrəm iist tə west tə brin əs wərrk or liəv əs rest ðعər də:un bilo: ðə sti:p hilzə:Id dru: tə:Im ən tə:Id ðə sprin də flo: ən $\mathrm{m} \Lambda$ ðərz ðعər vər jiərz əgpn lik de:tərz nə:u əkımən pn to blu:m (h)wen ðe: bi: wi:k ən wpn went də:un ðə steps vər wə:tər

ən (h)wpt də jandər rijərz tel ərinən t $\int a n d z I z ~ b e l ~ b(\partial:) I ~ b e l$

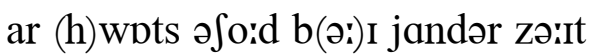
ə vo:k in (h)wə:It əppn ðə ro:d b $\Lambda t$ ðət b(ə:)I dzan ə wudliz zə:Id ðərz nə:u əbl $\Lambda$ fən vər (h)Iz brə:Id ə pərrti mæid ðət vsst hi: spə:Id gwæin də:un ðə steps vər wə:tər

ðo: $\int i:$ tIz tru: Iz fjeər ən kə:In(d) ðər strl bi: muər əleft bihə:in(d) sə kliənz ðə lə:It ðə zın də gi: sə spraks ə bi: (h)wen zımərz brə:it ən If ə:IV $1 \Lambda \mathrm{k}$ ə:I wu(:)nt bi: slo: tə tjek pf (w)uin ðət ə:I də no: ətripən gærli tu: ən fro: әppn ðə steps vər wə:tər

(h)ər f $\varepsilon: ð ə r$ Idən pu(:)ər bət vju: In parIf bi: so wel to du: vər (h)Iz o:n kəruz də swıy ðər tæilz bihə:In(d) (h)Iz pæilz bilo: (h)Iz bə:uz 
An' then ageän to win my love,

Why, she's as hwomely as a dove,

An' don't hold up herzelf above

Gwaïn down the steps vor water.

Gwain down the steps vor water! No!

How handsome it do meäke her grow.

If she'd be straïght, or walk abrode, out of doors

To tread her road wi' comely gait,

She coulden do a better thing

To zet herzelf upright, than bring

Her pitcher on her head, vrom spring

Upon the steps, wi' water.

No! don't ye neäme in woone seäme breath one

Wi' bachelors, the husband's he'th;

The happy pleäce, where vingers thin

Do pull woone's chin, or pat woone's feäce.

But still the bleäme is their's, to slight

Their happiness, wi' such a zight

O' maïdens, mornèn, noon, an' night,

A-gwain down steps vor water. 
ən ðعn əgjen tə win mə:I $1 \Lambda \mathrm{V}$

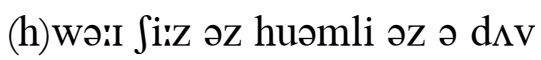
ən do:nt huəld $\Lambda \mathrm{p}$ hərz $\Lambda \mathrm{f}$ əb $\Lambda \mathrm{v}$ gwæIn dərun ðə steps vər wə:tər

gwæIn də:un ðə steps vər wə:tər no: hə:u han(d)səm it də mjek (h)ər gro: If $\int i$ id bi: stræit ar we:k əbro:d to tred (h)ər ro:d wi kımli gæit Si: kudən du: ə betər ठıy tə zet hərzムf $\Lambda$ prə:It ðən brin (h)ər pitfər pn (h)ər hed vrəm sprin əppn ðə steps wi wə:tər

no: do:nt i: njem in (w)u:n sjem bre $\theta$

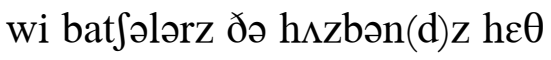
ðə hapi pljes (h)wər vingərz ठın də pul (w)uinz t fin or pat (w)uinz fjes bət stıl ðə bljem Iz ðərz tə slə:It ðər hapinis wi sit $\int$ ə zə:It ə mæidənz ma:rnən nu:n ən nə:It əgwæIn dərun steps vər wə:tər 
NoO soul did hear her lips complaïn,

An' she's a-gone vrom all her pain,

An' others' loss to her is gain

For she do live in heaven's love;

Vull many a longsome day an' week

She bore her ailèn, still, an' meek;

A-workèn while her strangth held on,

An' guidèn housework, when 'twer gone.

Vor Ellen Brine ov Allenburn,

Oh! there be souls to murn.

mourn

The last time I'd a-cast my zight

Upon her feäce, a-feäded white,

Wer in a zummer's mornèn light

In hall avore the smwold'rèn vier, fire

The while the childern beät the vloor,

In play, wi' tiny shoes they wore,

An' call'd their mother's eyes to view

The feät's their little limbs could do.

Oh! Ellen Brine ov Allenburn,

They childern now mus' murn.

Then woone, a-stoppèn vrom his reäce,

Went up, an' on her knee did pleäce

His hand, a-lookèn in her feäce,

An' wi' a smilèn mouth so small,

He zaid, "You promised us to goo

To Shroton feäir, an' teäke us two!"

She heärd it wi' her two white ears,

An' in her eyes there sprung two tears,

Vor Ellen Brine ov Allenburn

Did veel that they mus' murn. 
عlən brə:In əv alənbərrn

nu: so:l did hiər (h)ər lıps kəmplæIn

ən Si:z əgpn vrəm a:l (h)ər pæin

ən $\Lambda$ ðrz los tə (h)ər IZ gæın

vər $\int i$ : də liv in hevənz $1 \Lambda \mathrm{v}$

vul meni ə lpysəm de: ən wi:k

fi: buər (h)ər æIlən stıl ən mi:k

əwə:rkən (h)wəril (h)ər stray $\theta$ held pn

ən gə:Idən hə:uswərrk (h)wen twər gon

var عlən brə:In əv alənbə:rn

o: ðər bi: so:lz tə mə:rn

ðə 1ع:st tə:Im ə:Id əka:st mə:I zə:It

əppn (h)ər fjes əfjedid (h)wə:It

wər In ə zımərz ma:rnən lə:It

In ha:l əvuər ðə smuəldrən və:ıər

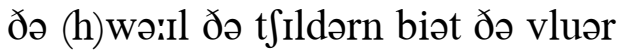

In plæı wi tə:Ini Ju:z de: wuər

ən kaild ðər $\mathrm{m} \Lambda$ ðərz ə:Iz tə vju:

ðə fiəts ðər litəl limz kud du:

o: દlən brə:In əv alənbə:rn

ðе: tfrldərn nə:u məs mərrn

ðعn (w)u:n əstppən vrəm (h)Iz rjes

went $\Lambda$ p ən pn (h)ər ni: did pljes

(h)Iz han(d) əlukən in (h)ər fjes

ən wi ə smə:ılən mə:u $\theta$ sə sma:l

hi: zed ju: promist əs to gu:

to $\int p d ə n$ fjeər ən tjek $\Lambda \mathrm{s}$ tu:

fi: hiərd it wi (h)ər tu: (h)wərit iərz

ən In (h)ər ə:Iz ðər spr $\Lambda$ y tu: tiərz

vər عlən brə:In əv alənbərrn

did vi:l ðət ðe: məs mə:rn 
September come, wi' Shroton feäir, But Ellen Brine wer never there! A heavy heart wer on the meäre horse Their father rod his hwomeward road. rode

'Tis true he brought zome feärèns back, gifts bought at a fair

Vor them two childern all in black;

But they had now, wi' plaÿthings new,

Noo mother vor to shew em to,

Vor Ellen Brine ov Allenburn

Would never mwore return. 


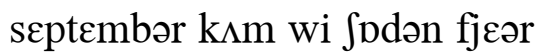
bət عlən brə:In wər nevər ðعər ə hevi ha:rt wər pn ðə mjeər ðər fع:ðər rod (h)Iz huəmwərd ro:d tIz tru: hi: bro:t zəm fjeərənz bak

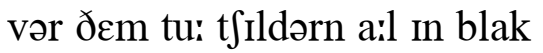
bət ðe: had nə:u wi plæıðınz nju: nu: $\mathrm{m} \Lambda$ ðər vər tə Jo: əm tu vər عlən brə:In əv alənbə:rn wud nevər muər ritə:rn 
THE MOTHERLESS CHILD

THE zun'd a-zet back tother night,

But in the zettèn pleäce

The clouds, a-redden'd by his light, its

Still glow'd avore my feäce.

An' I've a-lost my Meäry's smile,

I thought; but still I have her chile,

Zoo like her, that my eyes can treäce

The mother's in her daughter's feäce.

O little feäce so near to me,

An' like thy mother's gone; why need I zay

Sweet night cloud, wi' the glow o' my lost day,

Thy looks be always dear to me.

The zun'd a-zet another night;

But, by the moon on high,

He still did zend us back his light

Below a cwolder sky.

My Meäry's in a better land

I thought, but still her chile's at hand,

An' in her chile she'll zend me on

Her love, though she herzelf's a-gone.

O little chile so near to me,

An' like thy mother gone; why need I zay,

Sweet moon, the messenger vrom my lost day,

Thy looks be always dear to me. 
ðə m^ðərlıs tfə:Il(d)

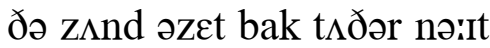

bət In ðə zetən pljes

ðə klə:udz əredənd b(ə:)I (h)Iz lə:It

strl glo:d əvuər mə:I fjes

วn ə:IV əlpst mə:I mjeəriz smə:Il

ə:I ठว:t bət strl ə:I hav (h)ər tfə:Il

zu: lik hər ðət mə:I ə:Iz kən trjes

ðə m^ðərz in (h)ər de:tərz fjes

o: litəl fjes so: niər to mi:

ən lik ðə:I m^ðərz gpn (h)wə:I ni:d ə:I ze:

swi(:)t nə:It klə:ud wi ðə glo: ə mə:I lpst de:

ðə:I luks bi: a:lwe:z diər tə mi:

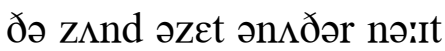

bət b(ə:) I ठə mu:n pn hə:I

hi: stıl did zen(d) əs bak (h)Iz lə:It

bilo: ə kuəldər skə:I

mə:I mjeəriz in ə betər lan(d)

ə:I ठs:t bət stıl (h)ər tfərilz ət han(d)

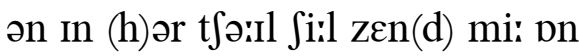

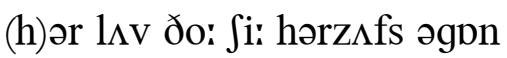

o: litəl tfə:il so: niər tə mi:

ən lik ðə:I m^ðər gpn (h)wə:I ni:d ə:I ze:

swi(:)t mu:n ðə mesindzər vrəm mə:I lpst de:

ठə:I luks bi: a:lwe:z dior to mi: 
AN' then we went along the gleädes

O' zunny turf, in quiv'rèn sheädes, shadows

A-windèn off, vrom hand to hand,

Along a path o' yollow zand,

An' clomb a stickle slope, an' vound

climbed, steep

An open patch o' lofty ground,

Up where a steätely tow'r did spring,

So high as highest larks do zing.

"Oh! Meäster Collins," then I zaid,

A-lookèn up wi' back-flung head;

Vor who but he, so mild o' feäce,

Should teäke me there to zee the pleäce.

"What is it then theäse tower do meän,

this

A-built so feäir, an' kept so cleän?”

"Ah! me," he zaid, wi' thoughtvul feäce,

"'Twer grief that zet theäse tower in pleäce.

The squier's e'thly life's a-blest

earthly

Wi' gifts that mwost do teäke vor best;

The lofty-pinion'd rufs do rise

roofs

To screen his head vrom stormy skies;

His land's a-spreadèn roun' his hall,

An' hands do leäbor at his call;

The while the ho'se do fling, wi' pride,

borse

His lofty head where he do guide;

But still his e'thly jaÿ's a-vled,

flown by

His woone true friend, his wife, is dead.

one

Zoo now her happy soul's a-gone,

so

An' he in grief's a-ling'rèn on,

Do do his heart zome good to show

it does

His love to flesh an' blood below. 
ðə ljediz tə:uər

ən ðعn wi: went əlpy ðə gljedz

ə zムni tərrf in kwIVrən $\int j \varepsilon d z$

əพə:In(d)ən pf vrəm han(d) tə han(d)

əlpy ə pe: $\theta$ ə jalər zan(d)

ən klım ə stıkəl slo:p ən və:un(d)

ən o:bən pat $\int$ lpfti grə:un(d)

$\Lambda \mathrm{p}$ (h)wər ə stjetli tə:uər did sprin

sə hə:I əz hə:IIst la:rks də zIn

o: mja:stər kplinz ðعn ə:I zed

əlukən $\Lambda$ p wi bakfl $\Lambda \mathrm{y}$ hed

vər hu: bət hi: sə mə:Ild ə fjes

Jud tjek mi: ðər to zi: ðə pljes

(h)wpt IZ It ðعn ðiəs tə:uər də miən

əbilt sə fjeər ən kept sə kliən

a: mi: hi: zed wi $\theta$ sttvul fjes

twər griff ðət zet ðiəs təuər in pljes

ðə skwə:ıวrz $\varepsilon \theta$ li lə:Ifs əblest

wi gifts ðət muəst də tjek vər best

ðə lpftipınjənd $\mathrm{r} \Lambda \mathrm{fs}$ də rə:Iz

tə skri:n (h)Iz hed vrəm sta:rmi skə:Iz

(h)Iz lan(d)z əspredən rə:un (h)Iz ha:l

ən han(d)z də ljebər ət (h)Iz ka:l

ðə (h)wə:Il ðə hps də flın wi prə:Id

(h)Iz lofti hed (h)wər hi: də gə:Id

bət stıl (h)Iz $\varepsilon \theta$ li dzæIz əvled

(h)IZ (w)u:n tru: fren(d) (h)IZ wə:If Iz ded

zu: nə:u (h)ər hapi so:lz əgon

ən hi: in griifs əlıngrən on

də du: (h)Iz hairt zım gud to Jo:

(h)Iz $1 \Lambda v$ to fle $\int$ on bl $\Lambda d$ bilo: 
An' zoo he rear'd, wi' smitten soul,

Theäse Leädy's Tower upon the knowl.

this

An' there you'll zee the tow'r do spring

Twice ten veet up, as roun's a ring,

Wi' pillars under mwolded eäves,

Above their heads a-carv'd wi' leaves;

An' have to peäce, a-walkèn round

pace

His voot, a hunderd veet o' ground.

An' there, above his upper wall,

A roundèd tow'r do spring so tall

'S a springèn arrow shot upright,

A hunderd giddy veet in height.

An' if you'd like to straïn your knees

A-climèn up above the trees,

To zee, wi' slowly wheelèn feäce,

The vur-sky'd land about the pleäce,

far-

You'll have a flight o' steps to wear

Vor forty veet, up steäir by steäir,

That roun' the risèn tow'r do wind,

Like withwind roun' the saplèn's rind,

bindweed

An' reach a landèn, wi' a seat,

To rest at last your weary veet,

'Ithin a breast be-screenèn wall,

To keep ye vrom a longsome vall.

An' roun' the windèn steäirs do spring

Aïght stwonèn pillars in a ring,

stone

A-reachèn up their heavy strangth

Drough forty veet o' slender langth,

through

To end wi' carvèd heads below

The broad-vloor'd landèn's aïry bow.

$\operatorname{arc}$

Aïght zides, as you do zee, do bound

The lower buildèn on the ground,

An' there in woone, a two-leav'd door

one

Do zwing above the marble vloor: 
ən zu: hi: reərd wi smitən so:l ðiəs ljediz tə:uər əppn ðə no:l ən ðər jəl zi: ðə tə:uər də sprin twəI:s ten viit $\Lambda p$ əz rəiunz $\partial$ rig wi pilərz $\Lambda$ ndər muəldid iəvz əb $\Lambda$ v ðər hedz əka:rvd wi li:vz ən hav tə pjes əwe:kən rə:un(d) (h)IZ vut a h^ndərd viit ə grəiun(d) ən ठər əb $\Lambda \mathrm{V}$ (h)Iz $\Lambda$ pər wa:l ə rə'undid tə'uər də sprin sə ta:1 z ə sprinən arə(r) $\int \mathrm{pt} \Lambda$ prə:It ə hındərd gidi vi:t in hə:It ən If jəd lərik tə stræin jər ni:z əklımən $\Lambda p$ əb $\Lambda \mathrm{v}$ ðə tri:z to zi: wi slo:li (h)willən fjes ðə və:rskə:Id lan(d) əbə:ut ðə pljes jəl hav ə flə:It ə steps tə weər vər fuərti vi:t $\Lambda p$ stjeər b(ə:)I stjeər ðət rə:un ðə rə:Izən tə:uər də wə:In(d) lik wıðwə:In(d) rə:un ðə saplənz rə:In(d) ən riit $\int$ ə lan(d)ən wi ə si:t to rest ət lesst jər wiəri viit ıðın ə brest biskri:nən wa:l to ki(:)p i: vrəm ə lpysəm va:l ən rə:un ðə wə:In(d)ən stjeərz də sprıy æit stuənən pilərz In ə rin əri:t〕ən $\Lambda$ p ðər hevi stray $\theta$ dru: fuorti vi:t a slendər lay $\theta$ tu $\varepsilon n(d)$ wi ka:rvəd hedz bilo: ðə bro:dvluərd lan(d)ənz æIri bo: æIt zə:Idz əz ju: də zi: də bə:un(d) ðə lo:ər bildən pn ðə grə:un(d) ən ðər In (w)u:n ə tu:liivd duər də zwIn əb 
An' aÿe, as luck do zoo betide

Our comèn, we can goo inside.

The door is oben now." An' zoo

The keeper kindly let us drough.

through

There as we softly trod the vloor

O' marble stwone, 'ithin the door,

The echoes ov our vootsteps vled

flew

Out roun' the wall, and over head;

An' there a-painted, zide by zide,

In memory o' the squier's bride,

In zeven païntèns, true to life,

Wer zeven zights o' wedded life.

Then Meäster Collins twold me all

The teäles a-païntèd roun' the wall;

An' vu'st the bride did stan' to plight

Her weddèn vow, below the light

A-shootèn down, so bright's a fleäme,

In drough a churches window freäme.

through

An' near the bride, on either hand,

You'd zee her comely bridemaïds stand,

Wi' eyelashes a-bent in streäks

O' brown above their bloomèn cheäks:

An' sheenèn feäir, in mellow light,

sbining

Wi' flowèn heäir, an' frocks o' white.

“An' here," good Meäster Collins cried,

"You'll zee a creädle at her zide,

An' there's her child, a-lyèn deep

'Ithin it, an' a-gone to sleep,

Wi' little eyelashes a-met

In fellow streäks, as black as jet;

The while her needle, over head,

Do nimbly leäd the snow-white thread, 
วn æI əz 1^k də zu: bitə:Id

ə:uər kımən wi kən gu: insə:Id

ðə duər IZ o:bən nə:u ən zu:

ðə ki(:)pər kə:In(d)li let əs dru:

ðər əz wi: spf(t)li trod ðə vluər

ə ma:rbəl stuən Iðın ðə duər

ði દko:z əv ə'uər vutsteps vled

ə:ut rə:un ðə wa:l ən(d) ə:vər hed

ən ðər əpæIntId zə:Id b(ə:)I zə:Id

In meməri ə ðə skwə:Iərz brə:Id

In zevən pæintənz tru: to lə:If

wər zevən zə:Its ə wedid lə:If

ðعn mjaistər kplinz tuəld mi: a:l

ðə tjelz əpæIntıd rə:un ðə wa:l

ən v $\Lambda$ st ðə brə:Id did stan tə plə:It

(h)ər wedən və:u bilo: ðə lə:it

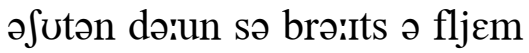

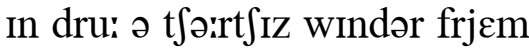

ən niər ðə brə:Id pn ə:Iðər han(d)

jəd zi: (h)ər kımli brə:IdmæIdz stan(d)

wi ə:Ila $\mathrm{fz}$ əbent in striəks

ə brə:un əb么v ðər blu:mən t tiəks

ən Siinən fjeər in melər lə:It

wi flo:ən hjeər ən froks ə (h)wə:It

ən hiər gud mja:stər kplinz krə:Id

jəl zi: ə krjedəl ət (h)ər zə:Id

ən ðərz (h)ər tfəril(d) ələ:ıən di:p

IðIn It ən əgpn to sli:p

wi litəl ə:Ila $\mathrm{fz}$ əmet

In felər striəks əz blak əz dzet

ðə (h)wə:Il (h)ər nIdəl ə:vər hed

də nImbli liəd ðə sno:(h)wə:It dred 
To zew a robe her love do meäke

Wi' happy leäbor vor his seäke.

“An' here a-geän's another pleäce,

Where she do zit wi' smilèn feäce,

An' while her bwoy do leän, wi' pride,

Ageän her lap, below her zide,

Her vinger tip do leäd his look

To zome good words o' God's own book.

“'An' next you'll zee her in her pleäce,

Avore her happy husband's feäce,

As he do zit, at evenèn-tide,

A-restèn by the vier-zide.

fireside

An' there the childern's heads do rise,

Wi' laughèn lips, an' beamèn eyes,

Above the bwoard, where she do lay

table

Her sheenèn tacklèn, wi' the tea.

shining cutlery and crockery

“An' here another zide do show

Her vinger in her scizzars' bow

Avore two daughters, that do stand,

Wi' leärnsome minds, to watch her hand

A-sheäpèn out, wi' skill an' ceäre,

A frock vor them to zew an' wear.

“Then next you'll zee her bend her head

Above her aillèn husband's bed,

sick (ailing)

A-fannèn, wi' an inward praÿ'r,

His burnèn brow wi' beäten aïr;

wafted

The while the clock, by candle light,

Do show that 'tis the dead o' night. 
tə zo: ə ro:b (h)ər $1 \Lambda \mathrm{v}$ də mjek

wi hapi ljebər vər (h)Iz sjek

ən hiər əgjenz ən^ðər pljes

(h)wər Ji: də zit wi smə:Ilən fjes

ən (h)wə:Il (h)ər bwə:I də liən wi prə:Id

əgjen (h)ər lap bilo: (h)ər zə:Id

(h)ər vingər tıp də liəd (h)Iz luk

to zım gud wə:rdz ə gpdz o:n buk

ən neks(t) jəl zi: (h)ər In (h)ər pljes

əvuər (h)ər hapi hızbən(d)z fjes

əz hi: də zit ət iivməntə:Id

ərestən b(ə:)I ðə və:Iərzə:Id

ən ðər ðə t $f$ Ildərnz hedz də rə:Iz

wi le:fən lips ən bi:mən ə:Iz

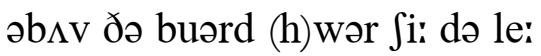

(h)ər Ji:nən taklən wi ðə te:

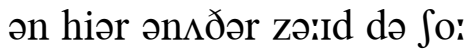

(h)ər vingər in (h)ər sizərz bo:

əvuər tu: de:tərz ðət də $\operatorname{stan}(\mathrm{d})$

wi la:rnsəm mə:In(d)z tə wpt $\int(h) ə r$ han(d)

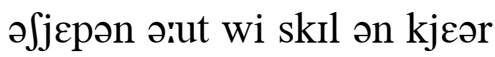

ə frok vər ðعm tə zo: ən weər

ðعn neks(t) jəl zi: (h)ər ben(d) (h)ər hed

əb $\Lambda$ v (h)ər ærlən h $\Lambda z b ə n(d) z$ bed

əfanən wi ən Inwərd prærr

(h)Iz bə:rnən brə:u wi biətən æIr

ðə (h)wə:Il ðə klpk b(ə:)I kandəl lə:It

də Jo: ðət tIz ðə ded ə nə:It 
"An' here ageän upon the wall, Where we do zee her last ov all, Her husband's head's a-hangèn low, 'Ithin his hands in deepest woe.

An' she, an angel ov his God,

Do cheer his soul below the rod,

A-liftèn up her han' to call

His eyes to writèn on the wall, As white as is her spotless robe,

'Hast thou rememberèd my servant Job?'

“An' zoo the squier, in grief o' soul,

Built up the Tower upon the knowl." 
ən hiər əgjen əppn ðə wa:l

(h)wər wi: də zi: (h)ər leist əv a:l

(h)ər hızbən(d)z hedz əhayən lo:

Iðın (h)Iz han(d)z In di:pıst wo:

ən Si: ən andzəl əv (h)Iz gpd

də tfiər (h)Iz so:l bilo: ðə rod

əlıftən $\Lambda p$ (h)ər han to ka:l

(h)Iz ə:Iz tə re:itən pn ðə wa:l

əz (h)wə:It əz IZ (h)ər spptlis ro:b

hast ðə:u rimembərəd mə:I sa:rvənt dzo:b

ən zu: ðə skwə:ıər in griff ə so:l

bilt $\Lambda$ p ðə tə:uər əppn ðə no:l 


\section{FATHERHOOD}

LET en zit, wi' his dog an' his cat, bim

Wi' their noses a-turn'd to the vier, fire

An' have all that a man should desire;

But there idden much reädship in that.

Whether vo'k mid have childern or no, isn't, sense folk may

Wou'dden meäke mighty odds in the maïn;

They do bring us mwore jaÿ wi' mwore ho,

joy, care

An' wi' nwone we've less jaÿ wi' less païn.

We be all lik' a zull's idle sheäre out,

plough's, share

An' shall rust out, unless we do wear out,

Lik' do-nothèn, rue-nothèn,

Dead alive dumps.

As vor me, why my life idden bound isn't

To my own heart alwone, among men;

I do live in myzelf, an' ageän

In the lives o' my childern all round:

I do live wi' my bwoy in his plaÿ,

An' ageän wi' my maïd in her zongs;

daughter

An' my heart is a-stirr'd wi' their jaÿ,

An' would burn at the zight o' their wrongs.

I ha' nine lives, an' zoo if a half

so

O'm do cry, why the rest o'm mid laugh

of them, may

All so plaÿvully, jaÿvully,

Happy wi' hope.

Tother night I come hwome a long road,

When the weather did sting an' did vreeze;

An' the snow-vor the day had a-snow'd-

Wer avroze on the boughs o' the trees; 
fє:ðərhud

let ən zit wi (h)Iz dpg ən (h)Iz kat wi ðər no:ziz ətə:rnd tə ðə və:ıər ən hav a:l dət ə man Jud dizə:ıər bət ðər Idən m $\mathrm{t} t \int$ riəd $\int \mathrm{Ip}$ in ðat (h)weðər vo:k mid hav tfildərn ar no: wudən mjek məsiti pdz in ðə mæIn ðe: də brin əs muər dzær wi muər ho:

on wi nuən wi:v les dzæI wi les pæin

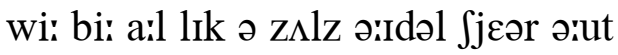
ən $\int ə 1$ r $\Lambda$ st ə:ut $\Lambda$ nles wi: də weər ərut lik du:n $\wedge \theta$ ən ru:n $\wedge \theta ə n$ $\mathrm{d} \varepsilon \mathrm{d}$ ələ:IV d $\Lambda \mathrm{mps}$

az vər mi: (h)wə:I mə:I lə:If Idən bə:un(d) tə mə:I o:n ha:rt əluən əmpy men

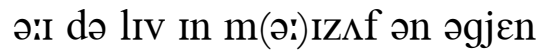
In ðə lə:IVZ ə mə:I t țldərn a:l rə:un(d) ə:I də liv wi mə:I bwə:I In (h)Iz plæI ən əgjen wi mə:I mæid in (h)ər zpyz ən mə: ha:rt IZ əstərrd wi ðər dzæI ən wud bə:rn ət ðə zə:It ə ðər rpyz ว:I hə nə:In lə:Ivz ən zu: If ə he:f o:m də krə:I (h)wə:I ðə rest o:m mid le:f a:l sə plæıvuli dzæıvuli hapi wi ho:p

tムðər nə:It ə:I kım huəm ə lpy ro:d

(h)wen ðə wعðər did stın ən did vri:z ən ðə sno: vər ðə de: had əsno:d wər əvro:z pn ðə bə:uz ə ðə tri:z 
An' my tooes an' my vingers wer num',

An' my veet wer so lumpy as logs, An' my ears wer so red's a cock's cwom';

comb

An my nose wer so cwold as a dog's;

But so soon's I got hwome I vorgot

Where my limbs wer a-cwold or wer hot,

When wi' loud cries an' proud cries

They coll'd me so cwold.

bugged

Vor the vu'st that I happen'd to meet

first

Come to pull my girtcwoat vrom my eärm,

greatcoat, arm

An' another did rub my feäce warm,

An' another hot-slipper'd my veet;

While their mother did cast on a stick,

Vor to keep the red vier alive;

fire

An' they all come so busy an' thick

As the bees vlee-èn into their hive,

An' they meäde me so happy an' proud,

That my heart could ha' crow'd out a-loud;

They did tweil zoo, an' smile zoo,

toil so

An' coll me so cwold.

As I zot wi' my teacup, at rest,

flying

There I pull'd out the taÿs I did bring;

sat

Men a-kickèn, a-wagg'd wi' a string,

An' goggle-ey'd dolls to be drest;

An' oh! vrom the childern there sprung

Such a charm when they handled their taÿs,

noise

That vor pleasure the bigger woones wrung

ones

Their two hands at the zight o' their jaÿs; 
วn mə:I tu:z ən mə:I vingərz wər n^m

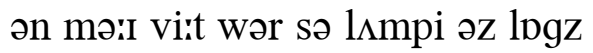

ən mə:I iərz wər sə redz ə kpks kuəm

ən mə:I no:z wər sə kuəld əz ə dogz

bət sə suinz ə:I gpt huəm ə:I vərgpt

(h)wər mə:I limz wər əkuəld ər wər hpt

(h)wen wi lə:ud krə:Iz ən prə:ud krə:Iz

ðe: kpld mi: sə kuəld

vər ðə v $\Lambda$ st ðət ə:I hapənd tə mi:t

$\mathrm{k} \Lambda \mathrm{m}$ tə pul mə:I gə:rtkuət vrəm mə:I ja:rm

ən ən $₫$ ðr did $r \Lambda b$ mə:I fjes wa:rm

ən әn^ðər hptslipərd mə:i vi:t

(h)wə:ıl ðər m^ðər did ka:st pn ə stık

vər tə ki(:)p ðə red və:ıər ələ:ıv

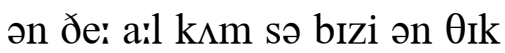

əz ðə bi:z vli:ən Intə ðər hə:IV

ən ðe: mjed mi: sə hapi on prə:ud

ðət mə:I ha:rt kud hə kro:d ə:ut ələ:ud

ðе: did twə:Il zu: ən smə:il zu:

on kpl mi: sə kuəld

az ว:I zat wi mə:I terk $\Lambda$ p ət rest

ðər ә:I puld ə:ut ðə tæIz ə:I did brin

men əkıkən əwagd wi ə strın

on gpgələ:id dolz tə bi: drest

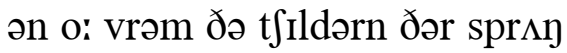

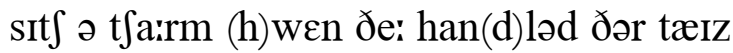

ðət vər plezər ðə bigər (w)uinz ruy

ðər tu: han(d)z ət ðə zə:It ə ðər dzæIz 
As the bwoys' bigger vaïces vell in

Wi' the maïdens a-titterèn thin,

An' their dancèn an' prancèn, An' little mouth's laughs.

Though 'tis hard stripes to breed em all up, If I'm only a-blest vrom above, They'll meäke me amends wi' their love, Vor their pillow, their pleäte, an' their cup; Though I shall be never a-spweil'd spoiled

Wi' the sarvice that money can buy;

Still the hands ov a wife an' a child

Be the blessèns ov low or ov high;

An' if there be mouths to be ved,

He that zent em can zend me their bread,

An' will smile on the chile

That's a-new on the knee. 
әz ðə bwə:Iz bigər væIsIz vel in wi ðə mæidənz ətitərən ðIn ən ðər de:nsən ən pre:nsən ən litəl mə:u(ð)z le:fs

ðo: tIz ha:rd strə:Ips tə bri:d əm a:l $\Lambda p$ If ə:Im o:nli əblest vrəm əb $\Lambda \mathrm{v}$ ðe:l mjek mi: əmen(d)z wi ðər $1 \Lambda \mathrm{v}$ vər ðər pilər ðər pljet ən ðər kıp

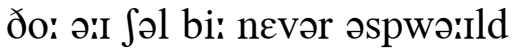
wi ðə sa:rvis ðət m^ni kən bə:I stıl ðə han(d)z əv ə wə:If ən ə t $\int$ ə:Il(d) bi: ðə blesənz əv lo: ar əv hə:I ən If ðər bi: mə:u(ठ)z tə bi: ved hi: ðət zent əm kən zen(d) mi: ðər bred

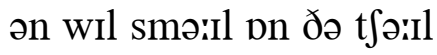
ðəts ənju: pn ðə ni: 
IN zummer, when the knaps wer bright

billocks

In cool-aïr'd evenèn's western light,

An' haÿ that had a-dried all day,

Did now lie grey, to dewy night;

I went, by happy chance, or doom,

Vrom Broadwoak Hill, athirt to Coomb,

across

An' met a maï in all her bloom:

The feaïrest maïd o' Newton.

She bore a basket that did ride

So light, she didden leän azide;

didn't

Her feäce wer oval, an' she smil'd

So sweet's a child, but walk'd wi' pride.

I spoke to her, but what I zaid

I didden know; wi' thoughts a-vled,

I spoke by heart, an' not by head,

Avore the maïd o' Newton.

I call'd her, oh! I don't know who,

'Twer by a neäme she never knew;

An' to the heel she stood upon,

She then brought on her hinder shoe,

An' stopp'd avore me, where we met,

An' wi' a smile woone can't vorget,

one

She zaid, wi' eyes a-zwimmèn wet,

'No, I be woone o' Newton.'

Then on I rambled to the west,

Below the zunny hangèn's breast,

slope's

Where, down athirt the little stream,

across

The brudge's beam did lie at rest: 
ðə mæId ə nju:tən

In z^mər (h)wen ðə naps wər brə:It In ku:læird i:vmənz westərn lə:it ən hæi ðət had ədrə:Id a:l de: did nə:u lə:I gre: to djuii nə:it ว:I went b(ə:)I hapi $t \int \varepsilon: n s$ ar du:m vrəm bro:d(w)uək hil əðə:rt tə ku:m ən met ə mæId in a:l (h)ər blu:m ðə fjeərəst mæid ə nju:tən

Si: buər ə ba:skıt ðət did rə:Id sə lə:It $\int i$ di: didən liən əzə:Id (h)ər fjes wər orvəl ən Ji: smə:Ild sə swi(:)ts a tfarild bət we:kt wi prə:Id ə:I spo:k tu hər bat (h)wpt ə:I zed ə:I didən no: wi ðっ:ts əvled ə:I spo:k b(ə:)I hairt ən not b(ə:)I hed əvuər ðə mærd ə njuitən

ə:I ka:ld hər o: ə:I do:nt no: hu: twər b(ə:)I ə njem Ji: nevər nju: an to ठə hi:l si: stud əppn fi: ðen bro:t pn (h)ər hə:Indər Ju: ən stppt əvuər mi: (h)wər wi: met ən wi ə smə:Il (w)u:n ke:nt vərget fi: zed wi ə:Iz əzwImən wet no: ə:I bi: (w)uin ə njuitən

ðعn pn ə:I rambəld tə ðə west bılo: ðə z^ni hayənz brest (h)wər də:un əðə:rt ðə litəl stri:m ðə brıd3IZ bi:m did lə:I ət rest 
But all the birds, wi' lively glee,

Did chirp an' hop vrom tree to tree,

As if it wer vrom pride, to zee

Goo by the maïd o' Newton.

By fancy led, at evenèn's glow,

I woonce did goo, a-rovèn slow,

once

Down where the elèms, stem by stem,

trunk by trunk

Do stan' to hem the grove below;

But after that, my veet vorzook

The grove, to seek the little brook

At Coomb, where I mid zometimes look,

might

To meet the maïd o' Newton. 
bət a:l ðə bə:rdz wi lə:Ivli gli:

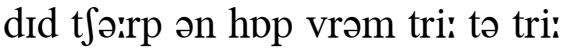

əZ If It wər vrəm prəild to zi:

gu: bə:I ðə mæId ə njuitən

b(ə:)I fansi led ət i:vmənz glo:

ə:I (w)urns did gu: əro:vən slo:

də'un (h)wər ði عləmz stem b(əi)I stem

də stan tə hem ðə gro:v bilo:

bət ع:tər ðat mə:I vi:t vərzuk

ðə gro:v tə si:k ðə litəl bruk

ət ku:m (h)wər ə:I mId zımtə:Imz luk

tə mi(:)t ðə mæId ə nju:tən 


\section{CHILDHOOD}

AYE, at that time our days wer but vew, few

An' our lim's wer but small, an' a-growèn;

An' then the feäir worold wer new,

An' life wer all hopevul an' gä̈;

An' the times o' the sproutèn o' leaves,

An' the cheäk-burnèn seasons o' mowèn,

An' bindèn o' red-headed sheaves,

Wer all welcome seasons o’ jaÿ.

Then the housen seem'd high, that be low,

An' the brook did seem wide that is narrow,

An' time, that do vlee, did goo slow,

An' veelèns now feeble wer strong,

An' our worold did end wi' the neämes

Ov the Sha'sbury Hill or Bulbarrow;

An' life did seem only the geämes

That we plaÿ'd as the days rolled along.

Then the rivers, an' high-timber'd lands,

An' the zilvery hills, 'ithout buyèn,

Did seem to come into our hands

Vrom others that own'd em avore;

An' all zickness, an' sorrow, an' need,

Seem'd to die wi' the wold vo'k a-dyèn,

old folk

An' leäve us vor ever a-freed

Vrom evils our vorefathers bore.

But happy be childern the while

They have elders a-livèn to love em,

An' teäke all the wearisome tweil

toil

That zome hands or others mus' do; 


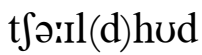

æI ət ðat tə:Im ə:uər de:Z wər bət vju: ən ə:uər limz wər bət sma:l ən əgro:ən ən ðعn ðə fjeər wə:rdəl wər nju: ən lə:If wər a:l ho:pvul ən gæı ən ðə tə:Imz ə ðə sprə:utən ə liivz

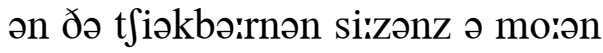
ən bə:In(d)ən ə redhedid Siivz wər a:l welkəm si:zənz ə dzæI

ðєn ðə hə:uzən si(:)md hə:I ðət bi: lo: ən ðə bruk did si(:)m wə:Id ðət IZ narə(r) ən tə:Im ðət də vli: did gu: slo: ən vi:lənz nə:u fi:bəl wər strpy ən ə:uər wə:rdəl did $\varepsilon n(d)$ wi ðə njemz əv ðə Sa:sbəri hil ar bulbarə(r) ən lə:If did si(:)m o:nli ðə gjemz ðət wi: plæId əz ðə de:z ro:ld əlpy

ðعn ðə rıvərz ən hə:Itımbərd lan(d)z ən ðə zilvəri hılz Iðə:ut bə:ıən did si(:)m to kım Intu əruər han(d)z vrəm $\Lambda$ ðərz ðət o:nd əm əvuər ən a:l ziknis ən sarə(r) ən ni:d si(:)md tə də:I wi ðə (w)uəld vo:k ədə:ıən ən liəv əs vor $\varepsilon$ vər əfriid vrəm i:vəlz ə:uər vuərfє:ðərz buər

bət hapi bi: tfIldərn ðə (h)wə:ıl ðe: hav عldərz əlıvən to $1 \Lambda \mathrm{v}$ əm ən tjek a:l ðə wiərisəm twə:ıl ðət zım han(d)z ər $\Lambda$ ðərz məs du: 
Like the low-headed shrubs that be warm, In the lewth o' the trees up above em, shelter A-screen'd vrom the cwold blowèn storm That the timber avore em must rue. 
lik ðə lo:hedıd $\int \mathrm{r} \Lambda$ bz ðət bi: wa:rm In ðə lu: $\theta$ ə ðə tri:z $\Lambda p$ əb $\Lambda \mathrm{v}$ əm əskri:nd vrəm ðə kuəld blo:ən sta:rm ðət ðə tImbər əvuər əm $\operatorname{məs}(\mathrm{t}) \mathrm{ru}$ 
WHEN mornèn winds, a-blowèn high,

Do zweep the clouds vrom all the sky, An' laurel-leaves do glitter bright, The while the newly broken light

Do brighten up, avore our view, The vields wi' green, an' hills wi' blue;

What then can highten to my eyes

The cheerful feäce ov e'th an' skies, earth But Meäry's smile, o' Morey's Mill, My rwose o' Mowy Lea.

An' when, at last, the evenèn dews

Do now begin to wet our shoes;

An' night's a-ridèn to the west, To stop our work, an' gi'e us rest, give

Oh! let the candle's ruddy gleäre

But brighten up her sheenèn heäir; shining

Or else, as she do walk abroad, outside

Let moonlight show, upon the road, My Meäry's smile, o' Morey's Mill, My rwose o' Mowy Lea.

An' O! mid never tears come on, may

To wash her feäce's blushes wan, Nor kill her smiles that now do plaÿ Like sparklèn weäves in zunny Mä̈; But mid she still, vor all she's gone Vrom souls she now do smile upon, Show others they can vind woone jaÿ one

To turn the hardest work to plaÿ:

My Meäry's smile, o' Morey's Mill, My rwose o' Mowy Lea. 
mjeəriz smə:Il

(h)wen ma:rnən win(d)z əblo:ən hə:I

də zwi:p ðə klə:udz vrəm a:l ðə skə:I

ən lprəl li:vz də glitər brə:It

ðə (h)wə:Il ðə nju:li bro:kən lə:It

də brə:Itən $\Lambda p$ əvuər ə:uər vju:

ðə vi:l(d)z wi gri:n ən hilz wi blu:

(h)wpt ðعn kən hə:Itən tə mə:I ə:Iz

ðә t fiərful fjes əv $\varepsilon \theta$ ən skə:Iz

bət mjeəriz smə:ıl ə muəriz mil

mə:I ruəz ə mo:i li:

ən (h)wen ət le:st ði i:vmən dju:z

də nə:u bigin tə wet ə:uər Ju:z

ən nə:Its ərə:Idən tə ðə west

tə stpp əruər wə:rk ən gi: əs rest

o: let ðə kandəlz rıdi gljeər

bət brə:itən $\Lambda p$ (h)ər Ji:nən hjeər

ar els az jii də we:k əbro:d

let mu:nlə:It fo: əppn ðə ro:d

mə:I mjeəriz smə:Il ə muəriz mil

mə:I ruəz ə mo:i li:

ən o: mid nevər tiərz k^m pn

to wp $(\mathrm{h}) \partial r$ fjesiz bl $\Lambda \int \mathrm{Iz}$ wpn

nar kıl (h)ər smə:Ilz ðət nə'u də plæI

lik spa:rklən wjevz in z $\Lambda$ ni mæi

bət mId fi: stıl vor a:l Ji:z gon

vrəm so:lz fi: nə:u də smə:ıl əppn

ノo: $\Lambda$ ðrz ðe: kən və:In(d) (w)uin dzæI

to tə:rn ðə ha:rdist wə:rk tə plæı

mə:I mjeəriz smə:Il ə muəriz mil

mə:I ruəz ə mo:i li: 
THE zun can zink, the stars mid rise,

An' woods be green to sheenèn skies;

The cock mid crow to mornèn light,

An' workvo'k zing to vallèn night;

The birds mid whissle on the spraÿ,

An' childern leäp in merry plaÿ,

But our's is now a lifeless pleäce,

Vor we've a-lost a smilèn feäce-

Young Meäry Meäd o' merry mood,

Vor she's a-woo'd an' wedded.

The dog that woonce wer glad to bear

Her fondlèn vingers down his heäir,

Do leän his head ageän the vloor,

To watch, wi' heavy eyes, the door;

An' men she zent so happy hwome

O' Zadurdays, do seem to come

To door, wi' downcast hearts, to miss

Wi' smiles below the clematis,

Young Meäry Meäd o' merry mood,

Vor she's a-woo'd an' wedded.

When they do draw the evenèn blind, An' when the evenèn light's a-tin'd, lost The cheerless vier do drow a gleäre fire, throw

O' light ageän her empty chair;

An' wordless gaps do now meäke thin

Their talk where woonce her vaïce come in.

Zoo lwonesome is her empty pleäce,

An' blest the house that ha' the feäce

O' Meäry Meäd, o' merry mood,

Now she's a-woo'd and wedded. 
mjeəri wedid

ðə z^n kən zınk ðə sta:rz mıd rə:IZ ən wudz bi: gri:n to Ji:nən skə:Iz ðə kpk mid kro: to ma:rnən lə:It ən wə:rkvo:k zin to va:lən nə:it ðə bə:rdz mid (h)wisəl pn ðə spræI ən t $\int$ Ildərn liəp in meri plæI bət ə:uərz Iz nə:u ə lə:Iflis pljes var wi:v əlpst ə smə:Ilən fjes j $\wedge$ m meəri miəd ə meri mu:d vər $\int i$ iz əwu:d ən wedid

ðə dpg ðət (w)u:ns wər glad tə beər (h)ər fon(d)lən vingərz də:un (h)Iz hjeər də liən (h)Iz hed əgjen ðə vluər to wpt $\int$ wi hevi ə:Iz ðə duər ən men Si: zent sə hapi huəm ə zadərde:z də si(:)m tə k $\wedge \mathrm{m}$ tə duər wi də:unkaist hairts tə mis wi smə:Ilz bilo: ðə klemətıs jıy mjeəri miəd ə meri mu:d vər Siiz əwu:d ən wedid

(h)wen ðe: də dre: ði i:vmən blə:ın(d) ən (h)wen ði i:vmən lə:tts ətə:In(d) ðə tfiərlıs və:ıər də dro: ə gljeər ə lə:It əgjen (h)ər $\varepsilon m(p)$ ti t $t \varepsilon \varepsilon r$ ən wə:rdlıs gaps də nə:u mjek ðın ðər te:k (h)wər (w)u:ns (h)ər væIs kım In zu: luənsəm Iz (h)ər $\varepsilon \mathrm{m}(\mathrm{p}) \mathrm{ti}$ pljes ən blest ðə hə:us ðət ha ðə fjes ə mjeəri miəd ə meri mu:d nə:u fiiz əwu:d ən(d) wedıd 
The day she left her father's he'th, bearth

Though sad, wer kept a day o' me'th, mirth An' dry-wheel'd waggons' empty beds Wer left 'ithin the tree-screen'd sheds; An' all the hosses, at their eäse,

Went snortèn up the flow'ry leäse, meadow But woone, the smartest for the roäd, one That pull'd away the dearest lwoadYoung Meäry Meäd o' merry mood, That wer a-woo'd an' wedded. 


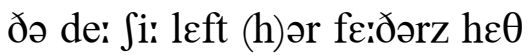

ðo: sad wər kept ə de: ə me $\theta$

ən drə:I(h)willd wagənz $\varepsilon \mathrm{m}(\mathrm{p}) \mathrm{ti}$ bedz

wər left ıðIn ðə trisskrind $\int \varepsilon d z$

ən a:l ðə hpsız ət ðər iəz

went sna:rtən $\Lambda$ p ðə flə:uri liəz

bət (w)u:n ðə sma:rtist vər ðə ruəd

ðət puld əwə:ı ðə diərıst luəd

j $\wedge$ y meəri miəd ə meri mu:d

ðət wər əwu:d an wedid 
WI' smokeless tuns an' empty halls, chimneys

An' moss a-clingèn to the walls,

In ev'ry wind the lofty tow'rs

Do teäke the zun, an' bear the show'rs;

An' there, 'ithin a geät a-hung, bebind a gate

But vasten'd up, an' never swung,

Upon the pillar, all alwone,

Do stan' the little bwoy o' stwone;

'S a poppy bud mid linger on, may

Vorseäken, when the wheat's a-gone.

An' there, then, wi' his bow let slack,

An' little quiver at his back,

Drough het an' wet, the little chile

through heat

Vrom day to day do stan' an' smile.

When vu'st the light, a-risèn weak, first

At break o' day, do smite his cheäk,

Or while, at noon, the leafy bough

Do cast a sheäde a-thirt his brow, shadow across

Or when at night the warm-breath'd cows

Do sleep by moon-belighted boughs;

An' there the while the rooks do bring

Their scroff to build their nest in Spring,

twigs

Or zwallows in the zummer day

Do cling their little huts o' clay, attach

'Ithin the raïnless sheädes, below

The steadvast arches' mossy bow.

Or when, in Fall, the woak do shed span oak

The leaves, a-wither'd, vrom his head, An' western win's, a-blowèn cool,

Do dreve em out athirt the pool, drive, across

Or Winter's clouds do gather dark

An' wet, wi' rain, the elem's bark, 
ðə stuənən bwə:I əppn ðə pılər

wi smo:klıs tınz on $\varepsilon m(p)$ ti ha:lz ən mps əklinən tə ठə wa:lz In $\varepsilon v r i$ win(d) ðə lpfti tə:uərz

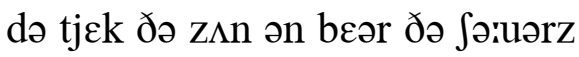
ən ठər IðIn ə gjət əh^y bət va:sənd $\Lambda \mathrm{p}$ ən nevər sw $\Lambda$ əppn ðə pilər ail əluən də stan ðə litəl bwə:I ə stuən z ə pppi b $\Lambda$ d mid lingər pn varsjekən (h)wen ðə (h)witts əgpn ən ठər ðعn wi (h)Iz bo: let slak ən litəl kwivər ət (h)Iz bak dru: het ən wet ðə litəl tfə:Il vrəm de: to de: də stan ən smə:Il (h)wعn vıst ðə lə:It ərə:Izən wi:k ət bre:k ə de: də sməitt (h)Iz t fiək ar (h)wə:ıl ət nu:n ðə li:fi bə:u

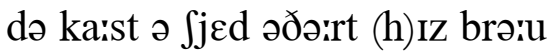

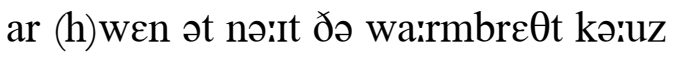
də sli:p b(ə:)I mu:nbilə:itıd bə:uz ən ðər ðə (h)wə:ıl ðə ruks də brin ðər skrof to bild ðər nest in sprin ar zwplərz in ðə zムmər de: də klın ठər litəl hıts ə kle: ıðın ðə ræInlıs $\int j \varepsilon d z$ bilo:

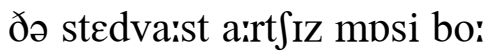
ar (h)wen in fa:l ðə (w)uək də $\int \varepsilon d$ ðə liivz əwıðərd vrəm (h)Iz hed ən westərn win (d)z əblo:ən ku:l də dre:v əm ə:ut əðə:rt ðə pu:l ar wintərz klə:udz də gaðər da:rk ən wet wi ræın ði عləmz ba:rk 
You'll zee his pretty smile betwixt

His little sheäde-mark'd lips a-fix'd;

As there his little sheäpe do bide

Drough day an' night, an' time an' tide, through

An' never change his size or dress,

Nor overgrow his prettiness.

But, oh! thik child, that we do vind that

In childhood still, do call to mind

A little bwoy a-call'd by death,

Long years agoo, vrom our sad he'th;

bearth

An' I, in thought, can zee en dim

The seäme in feäce, the seäme in lim'.

My heäir mid whiten as the snow, may

My limbs grow weak, my step wear slow,

My droopèn head mid slowly vall

Above the han'-staff's glossy ball,

An' yeet, vor all a wid'nèn span

walking-stick's

Ov years, mid change a livèn man,

My little child do still appear

To me wi' all his childhood's gear,

'Ithout a beard upon his chin,

'Ithout a wrinkle in his skin,

A-livèn on, a child the seäme

In look, an' sheäpe, an' size, an neäme. 
jəl zi: (h)Iz pərrti smə:Il bitwrkst

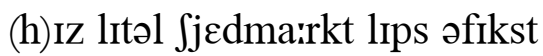

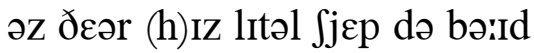

dru: de: ən nə:It ən tə:Im ən tə:Id

on nevər tfand3 (h)Iz sə:Iz or dres

nar o:vərgro: (h)Iz pə:rtines

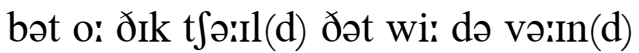

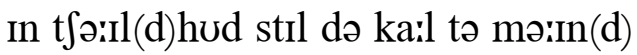

ə litəl bwə:I əka:ld b(ə:)I de $\theta$

lon jiərz əgu: vrəm ə:uər sad he $\theta$

ən ə:I in ðoit kən zi: ən dim

ðə sjem in fjes ðə sjem in lim

mə:I hjeər mId (h)wə:Itən əz ðə sno:

mə:I limz gro: wi:k mə:I step weər slo:

mə:I dru:pən hed mid slo:li va:l

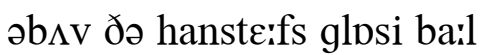

ən (j)i:t vər a:l ə wə:Idnən span

əv jiərz mid tfandz ə livən man

mə:I litəl tfəiıl(d) də stıl əpiər

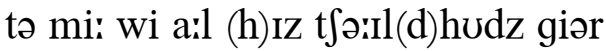

ıðə:ut ə biərd əppn (h)Iz t $\int$ In

ıðə’ut ə rınkəl In (h)Iz skın

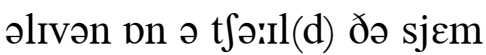

In luk ən $\int j \varepsilon p$ ən sə:IZ ən njem 
IF souls should only sheen so bright shine

In heaven as in e'thly light, earthly

An' nothèn better wer the ceäse,

How comely still, in sheäpe an' feäce,

Would many reach thik happy pleäce,-

that

The hopeful souls that in their prime

Ha' seem'd a-took avore their time-

The young that died in beauty.

But when woone's lim's ha' lost their strangth

one's

A-tweilèn drough a lifetime's langth,

An' over cheäks a-growèn wold

toiling through

The slowly-weästen years ha' rolled

The deep'nèn wrinkle's hollow vwold;

fold

When life is ripe, then death do call

Vor less ov thought, than when do vall

On young vo'ks in their beauty.

folk.

But pinèn souls, wi' heads a-hung

In heavy sorrow vor the young,

The sister ov the brother dead,

The father wi' a child a-vled,

The husband when his bride ha' laid

Her head at rest, noo mwore to turn,

Have all a-vound the time to murn

mourn

Vor youth that died in beauty.

An' yeet the church, where praÿer do rise

Vrom thoughtvul souls, wi' downcast eyes,

An' village greens, a-beät half beäre

bare

By dancers that do meet, an' weär

Such merry looks at feäst an' feäir, 
ðə j^y ðət də:Id In bju:ti

If so:lz Jud o:nli fiin sə brə:It

In hevən əz In $\varepsilon \theta$ li lə:It

ən $\mathrm{n} \wedge \theta ə n$ betər wər ðə kjes

hə:u kımli stıl in $\int j \varepsilon p$ ən fjes

wud meni ri:t ðık hapi pljes

ðə ho:pful so:lz ðət In ðər prə:Im

hə si(:)md ətuk əvuər ðər tə:ım

ðə j^y ðət də:Id In bju:ti

bət (h)wen (w)u:nz limz hə lpst ðər $\operatorname{stray} \theta$

ətwə:Ilən dru: ə lə:Iftə:Imz lan $\theta$

ən o:vər t $\mathrm{t}$ iəks əgro:ən (w)uəld

ðə slo:liwjestən jiərz hə ro:ld

ðə di:pnən rinkəlz hplər vuəld

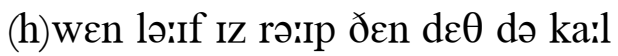

vər les əv ðっ:t ðən (h)wen də va:l

pn j $\Lambda$ y vo:ks in ðər bju:ti

bət pə:Inən so:lz wi hedz əh^y

In hevi sarə vər ðə j $\Lambda$ y

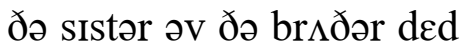

ðə fع:ðər wi ə tfə:Il(d) əvled

ðə hızbən(d) (h)wen (h)Iz brə:Id hə led

(h)ər hed ət rest nu: muər to tə:rn

hav a:l əvə:un(d) ðə tə:Im tə mə:rn

vər ju: $\theta$ ðət də:Id in bju:ti

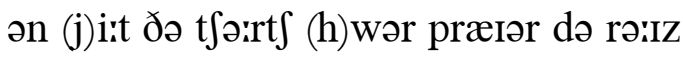

vrəm $\theta$ s:tvul so:lz wi də:unkaist ə:Iz

ən viləd3 griinz əbiət he:f bjeər

b(ə:)I de:nsərz ðət də mi(:)t ən weər

sit $\int$ meri luks ət fiəst ən fjeər 
Do gather under leätest skies,

Their bloomèn cheäks an' sparklèn eyes,

Though young ha' died in beauty.

But still the dead shall mwore than keep

The beauty ov their eärly sleep;

Where comely looks shall never weär

Uncomely, under tweil an' ceäre.

toil

The feäir at death be always feäir,

Still feäir to livers' thought an' love,

An' feäirer still to God above,

Than when they died in beauty. 
də gaðər $\Lambda$ ndər ljetıst skə:Iz ðər blu:mən $\mathrm{t} \int \mathrm{j}$ əəks ən sparklən ə:Iz ðo: j $\Lambda$ y hə də:Id In bju:ti

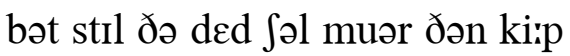
ðə bju:ti əv ðər jə:rli sli:p (h)wər kımli luks Jəl nevər weər nkkımli $\Lambda$ ndər twəril ən kjeər ðə fjeər ət $d \varepsilon \theta$ bi: a:lwe:z fjeər stıl fjeər tə livərz ðo:t ən $1 \Lambda \mathrm{v}$ ən fjeərər stıl tə gpd $\partial b \Lambda \mathrm{v}$ ðən (h)wen ðe: də:Id In bju:ti 
FAIR EMILY OV YARROW MILL

DEAR Yarrowham, 'twer many miles

Vrom thy green meäds that, in my walk,

I met a maïd wi' winnèn smiles,

That talk'd as vo'k at hwome do talk;

folk

An' who at last should she be vound,

Ov all the souls the sky do bound,

But woone that trod at vu'st thy groun'

Fair Emily ov Yarrow Mill.

But thy wold house an' elmy nook, old

An' wall-screen'd geärden's mossy zides,

Thy grassy meäds an' zedgy brook,

An' high-bank'd leänes, wi' sheädy rides,

Wer all a-known to me by light

Ov eärly days, a-quench'd by night,

Avore they met the younger zight

Ov Emily ov Yarrow Mill.

An' now my heart do leäp to think

O' times that I've a-spent in plaÿ,

Bezide thy river's rushy brink,

Upon a deäizybed o' Maÿ;

I lov'd the friends thy land ha' bore,

An' I do love the paths they wore,

An' I do love thee all the mwore,

Vor Emily ov Yarrow Mill.

When bright above the e'th below

earth

The moon do spread abroad his light,

around

An' aïr o' zummer nights do blow

Athirt the vields in plaÿsome flight,

across 
fjeər عmıli əv jarə(r) mil

diər jarəhəm twər meni mə:Ilz

vrəm ðə:I gri:n miədz ðət In mə:I we:k

ว:I met ə mæId wi winən smə:Ilz

ðət te:kt əz vo:k ət huəm də te:k

ən hu: ət leist Jud fi: bi: vərun(d)

əv a:l ðə so:lz ðə skə:I də bə:un(d)

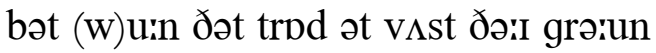

fjeər عmıli əv jarə(r) mil

bət ðə:I (w)uəld hə:us ən عlmi nuk

ən wa:lskri:nd gja:rdənz mpsi zə:Idz

ðə:I gra:si miədz ən zedzi bruk

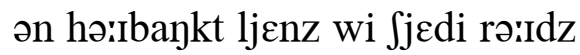

wər a:l əno:n tə mi: b(ə:)I lə:It

əv jə:rli de:z əkwentft b(ə:)I nə:It

әvuər ðе: met ðə j^ygər zə:It

əv عmili əv jarə(r) mil

ən nə:u mə:I ha:rt də liəp tə ðınk

ə tə:Imz ðət ə:IV əspent in plæI

bızə:Id ðə:I rIvərz $\mathrm{r} \Lambda \int \mathrm{i}$ brink

әppn ə djezibed ə mæI

ə:I $1 \Lambda$ vd ðə fren(d)z ठə:I lan(d) hə buər

ən ə:I də $1 \Lambda \mathrm{v}$ ðə pe:ðz ðе: wuər

ən ə:I də $1 \Lambda \mathrm{v}$ ði: a:l ðə muər

var عmıli əv jarə(r) mil

(h)wen brə:It əb $\Lambda \mathrm{v}$ ði $\varepsilon \theta$ bilo:

ðə mu:n də spred əbro:d (h)Iz lə:It

ən æIr ə zımər nə:Its də blo:

əðə:rt ðə vi:l(d)z In plæIsəm flə:It 
'Tis then delightsome under all

The sheädes o' boughs by path or wall, shadows

But mwostly thine when they do vall

On Emily ov Yarrow Mill. 
tIz ðعn dilə:Itsəm $\Lambda$ ndər a:l

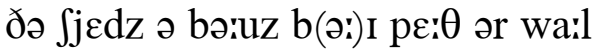

bət muəstli ðə:In (h)wen ðe: də va:l

pn عmili əv jarə(r) mil 
AYE, aye, the leäne wi' flow'ry zides

A-kept so lew, by hazzle-wrides,

Wi' beds o' grægles out in bloom,

sheltered by hazel-clumps

Below the timber's windless gloom, bluebells

An' geäte that I've a-swung,

An' rod as he's a-hung, ridden on

When I wer young, in Woakley Coomb.

'Twer there at feäst we all did pass

The evenèn on the leänezide grass,

Out where the geäte do let us drough,

Below the woak-trees in the lew, through

In merry geämes an' fun

That meäde us skip an' run,

Wi' burnèn zun, an' sky o' blue.

But still there come a scud that drove

The titt'rèn maïdens vrom the grove;

An' there a-left wer flow'ry mound,

'Ithout a vaïce, 'ithout a sound,

Unless the air did blow

Drough ruslèn leaves, an' drow

through, throw

The rain drops low, upon the ground.

I linger'd there an' miss'd the naise;

noise

I linger'd there an' miss'd our jaÿs;

I miss'd woone soul beyond the rest;

oak-trees, shelter

The maid that I do like the best.

Vor where her vaïce is gaÿ

An' where her smiles do plaÿ,

There's always jaÿ vor ev'ry breast. 
ðə skıd

æı æI ðə ljen wi flə:uri zə:Idz əkept sə lu: b(ə:)I hazəlrə:Idz wi bedz ə gre:gəlz ə:ut in blu:m bilo: ðə tImbərz win(d)ləs glu:m ən gjet ðət ə:IV əsw ən rod əz hi:z əh^y (h)wen ə:I wər j $\Lambda$ y In (w)uəkli ku:m

twər ðər ət fiəst wi: a:l did pa:s ði i:vmən pn ðə ljenzə:Id gra:s ə:ut (h)wər ðə gjet də let əs dru: bilo: ðə (w)uəktri:z in ðə lu: In meri gjemz on f $\Lambda$ n ðət mjed əs skip ən r $\wedge$ n wi bərrnən zムn ən skə:I ə blu:

bət stıl ðər k^m ə skıd ðət dro:v ðə titrən mæidənz vrəm ðə gro:v ən ðعər əleft wər flə:uri mə:un(d) ıðə:ut ə væı ıðə:ut ə sə:un(d) $\Lambda$ nles ði æir did blo: dru: rıslən li:vz ən dro: ðə ræIn draps lo: əppn ðə grə:un(d)

ə:I lingərd ðعər ən mIst ðə næIz ə:I lingərd ðعər ən mist ə:uər dzæız ə:I mIst (w)u:n so:l bijand ðə rest ðə mæId ðət ə:I də lə:Ik ðə best vər (h)wər (h)ər væIs IZ gæI ən (h)wər (h)ər smərilz də plæI ðərz a:lwe:z dzæI vər evri brest 
Vor zome vo'k out abroad ha' me'th,

But nwone at hwome bezide the he'th;

An' zome ha' smiles vor strangers' view,

An' frowns vor kith an' kin to rue;

But her sweet vaïce do vall,

Wi' kindly words to all,

Both big an' small, the whole day drough.

through

An' when the evenèn sky wer peäle,

We heärd the warblèn nightèngeäle,

A-drawèn out his lwonesome zong,

In windèn music down the drong;

lane

An' Jenny vrom her he'th,

bearth

Come out, though not in me'th,

mirth

But held her breath, to hear his zong.

Then, while the bird wi' oben bill

Did warble on, her vaïce wer still;

An' as she stood avore me, bound

In stillness to the flow'ry mound,

"The bird's a jaÿ to zome,"

I thought, "but when he's dum,

silent

Her vaïce will come, wi' sweeter sound." 
vər z^m vo:k ə:ut əbro:d ha me $\theta$

bət nuən ət huəm bizəiId ðə he $\theta$

ən z^m ha sməillz vər strandzərz vju:

ən frə:unz vər ki $\theta$ ən kin tə ru:

bət (h)ər swi(:)t væIs də va:l

wi kə:In(d)li wərrdz tu a:l

buəð big ən sma:l ðə huəl de: dru:

ən (h)wen ði i:vmən skə:I wər pjel

wi: hiərd ðə wa:rblən nə:təngjel

ədre:ən ə:ut (h)Iz luənsəm zpy

In wə:In(d)ən mju:zık də:un ðə droy

ən dzєni vrəm (h)ər he $\theta$

kım ə:ut ðo: npt in me $\theta$

bət held (h)ər bre $\theta$ to hiər (h)Iz zpy

ðعn (h)wəril ðə bə:rd wi o:bən bil

did warrbəl pn (h)ər væIs wər stıl

ən az fii stud əvuər mi: bə:un(d)

In strlnis tə ðə flə:uri mə:un(d)

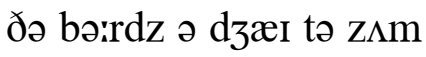

ə:I ðo:t bət (h)wen hi:z d $\Lambda \mathrm{m}$

(h)ər væIs wil kım wi swi(:)tər sərun(d) 


\section{MINDÈN HOUSE}

'TWER when the vo'k wer out to hawl folk

A vield o' haÿ a day in June, An' when the zun begun to vall

Toward the west in afternoon,

Woone only wer a-left behind one

To bide indoors, at hwome, an' mind

The house, an' answer vo'k avore

The geäte or door,- - young Fanny Deäne.

The air 'ithin the geärden wall

Wer deadly still, unless the bee

Did hummy by, or in the hall

The clock did ring a-hettèn dree, striking three

An' there, wi' busy hands, inside

The iron ceäsement, oben'd wide,

Did zit an' pull wi' nimble twitch

Her tiny stitch, young Fanny Deäne.

As there she zot she heärd two blows

A-knock'd upon the rumblèn door,

An' laid azide her work, an' rose,

An' walk'd out feäir, athirt the vloor;

across

An' there, a-holdèn in his hand

His bridled meäre, a youth did stand, borse

An' mildly twold his neäme and pleäce

Avore the feäce o' Fanny Deäne.

He twold her that he had on hand Zome business on his father's zide, But what she didden understand; didn't An' zoo she ax'd en if he'd ride so, asked him

Out where her father mid be vound, might Bezide the plow, in Cowslip Ground; wagon 
mə:In(d)ən hə:us

twər (h)wen ðə vo:k wər ə:ut to ha:l

ə vi:l(d) ə hæi ə de: In dzuin

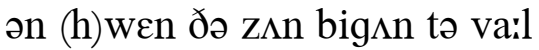

təwa:rd ðə west in ع:tərnu:n

(w)u:n o:nli wər əleft bihə:In(d)

tə bə:Id Induərz at huəm ən mə:in(d)

ðə hə:us ən ع:nsər vo:k əvuər

ðə gjet ər duər j $\wedge$ y fani djen

ði æır Iðın ðə gja:rdən wa:l

wər dedli stıl $\Lambda$ nles ðə bi:

did hımi bə:I ar in ðə ha:l

ðə klpk did rıj əhetən dri:

ən ðər wi bızi han(d)z Insə:Id

ði ə:Iərn kjesmənt o:bənd wə:Id

did zit ən pul wi nimbəl twits

(h)ər tə:Ini strt $\int \mathrm{j} \Lambda \mathrm{y}$ fani djen

az ðər Si: zat fi: hiərd tu: blo:z ənpkt əppn ðə rımblən duər ən led əzə:Id (h)ər wərrk ən ro:z ən wع:kt ərut fjeər əðə:rt ðə vluər ən ðər əho:ldən In (h)Iz han(d) (h)Iz brə:Idəld mjeər ə ju: $\theta$ did stan(d) ən mə:Ildli tuəld (h)Iz njem ən(d) pljes əvuər ðə fjes ə fani djen

hi: tuəld (h)ər dət hi: had pn han(d) zəm biznis pn (h)Iz fe:ðərz zə:Id bət (h)wpt Si: didən $\Lambda$ ndərstan(d) ən zu: $\int i$ : a:kst ən If hi:d rə:Id ə:ut (h)wər (h)ər fe:ðər mId bi: vərun(d) bizə:Id ðə plə:u in kə:uslip grə:un(d) 
An' there he went, but left his mind

Back there behind, wi' Fanny Deäne.

An' oh! his hwomeward road wer gaÿ

In aïr a-blowèn, whiff by whiff,

While sheenèn water-weäves did plaÿ

sbining

An' boughs did swaÿ above the cliff;

Vor Time had now a-show'd en dim

bim

The jaÿ it had in store vor him;

joy

An' when he went thik road ageän

that

His errand then wer Fanny Deäne.

How strangely things be brought about

By Providence, noo tongue can tell,

She minded house, when vo'k wer out, folk

An' zoo mus' bid the house farewell;

The bees mid hum, the clock mid call

may

The lwonesome hours 'ithin the hall,

But in behind the woaken door,

oak

There's now noo mwore a Fanny Deäne. 
ən ðər hi: went bət left (h)Iz mə:In(d) bak ðər bihə:In(d) wi fani djen

ən o: (h)Iz huəmwərd ro:d wər gæI In æIr əblo:ən (h)wIf b(ə:)I (h)wIf (h)wə:Il fiinən wo:tərwjevz did plæI

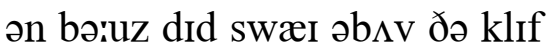
var tə:Im had nə:u əfo:d ən dim ðə dzæI It had in stuər vər hIm ən (h)wen ə went ठik ro:d əgjen (h)IZ $\varepsilon r ə n(d)$ ðعn wər fani djen

hə:u strandzli ðınz bi: bro:t əbə:ut b(ə:)I providəns nu: t $\Lambda$ j kən t $\mathrm{t} 1$ Si: mə:indid hə:us (h)wen vo:k wər ərut ən zu: mıs bid ðə hə:us fjearwel ðə bi:z mid h^m ðə klpk mid ka:l ðə luənsəm ə:uərz Iðın ðə ha:l bət In bihə:In(d) ðə (w)uəkən duər ðərz nə:u nu: muər ə fani djen 
A MAÏD wi' many gifts o' greäce, A maïd wi' ever-smilèn feäce, A child o' yours my chilhood's pleäce,

$\mathrm{O}$ leänèn lawns ov Allen;

'S a-walkèn where your stream do flow, A-blushèn where your flowers do blow, bloom A-smilèn where your zun do glow,

O leänèn lawns ov Allen. An' good, however good's a-waïgh'd, 'S the lovely maïd ov Elwell Meäd.

An' oh! if I could teäme an' guide tame

The winds above the e'th, an' ride earth

As light as shootèn stars do glide,

$O$ leänèn lawns ov Allen,

To you I'd teäke my daily flight,

Drough dark'nèn aïr in evenèn's light, through An' bid her every night "Good night,"

O leänèn lawns ov Allen.

Vor good, however good's a-waïgh'd, 'S the lovely maïd ov Elwell Meäd.

An' when your hedges' slooes be blue, sloes By blackberries o' dark'nèn hue, An' spiders' webs behung wi' dew,

$O$ leänèn lawns ov Allen, Avore the winter air's a-chill'd, Avore your winter brook's a-vill'd, Avore your zummer flow'rs be kill'd,

O leänèn lawns ov Allen;

I there would meet, in white arraÿ'd,

The lovely maïd ov Elwell Meäd. 


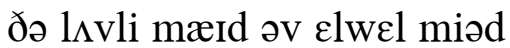

ə mæId wi meni gifts ə grjes

ə mæid wi عvərsmə:Ilən fjes

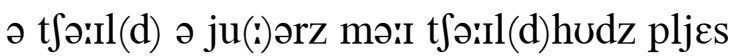

o: liənən le:nz əv alən

$\mathrm{z}$ əw\&:kən (h)wər jər stri:m də flo:

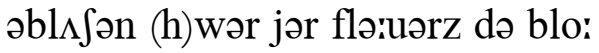

əsmə:Ilən (h)wər jər z^n də glo:

o: liənən le:nz əv alən

ən gud hə:uعvər gudz əwæId

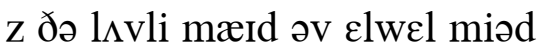

ən o: If ə:I kud tjem ən gə:Id

ðə win $(d) z$ əb $\Lambda v$ ði $\varepsilon \theta$ ən rə:Id

əz lə:it əz $\int u t ə n$ sta:rz də glə:id

o: liənən le:nz əv alən

to ju: ə:Id tjek mə:I de:li flə:it

dru: da:rknən æIr in iivmənz lə:it

ən bid (h)ər عvri nəitt gud nə:It

o: liənən le:nz əv alən

var gud hə:uعvər gudz əwæId

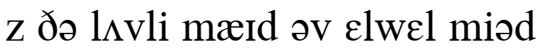

ən (h)wen jər hedzız slu:z bi: blu:

bi blakbəriz ə da:rknən hju:

ən spə:Idərz webz bihıy wi dju:

o: liənən le:nz əv alən

әvuər ðə wintər æIrz ət IIld

əvuər jər wintər bruks əvild

əvuər jər zımər flə:uərz bi: kıld

o: liənən le:nz əv alən

ə:I ठər wud mi(:)t In (h)wə:It əræId

ðə lıvli mæId əv عlwel miəd 
For when the zun, as birds do rise,

Do cast their sheädes vrom autum' skies,

shadows

A-sparklèn in her dewy eyes,

$O$ leänèn lawns ov Allen;

Then all your mossy paths below

The trees, wi' leaves a-vallèn slow,

falling

Like zinkèn fleäkes o' yollow snow,

$O$ leänèn lawns ov Allen,

Would be mwore teäkèn where there straÿ'd

The lovely maïd ov Elwell Meäd. 
var (h)wعn ðə z^n az bə:rdz də rə:Iz də ka:st ðər $\int j \varepsilon d z$ vrəm ə:təm skə:Iz əspa:rklən In (h)ər djuii ə:Iz

o: liənən le:nz əv alən ðعn a:l jər mpsi pe:ðz bilo: ðə tri:z wi li:vz əva:lən slo: lik zıjkən fljeks ə jalər sno:

o: liənən le:nz əv alən wud bi: muər tjekən (h)wər ðər stræId

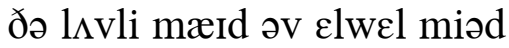




\section{OUR FATHERS’ WORKS}

AH! I do think, as I do tread

Theäse path, wi' elems overhead, this

A-climèn slowly up vrom Bridge,

By easy steps, to Broadwoak Ridge,

That all theäse roads that we do bruise

these

Wi' hosses' shoes, or heavy lwoads;

An' hedges' bands, where trees in row

Do rise an' grow aroun' the lands,

Be works that we've a-vound a-wrought

By our vorefathers' ceäre an' thought.

They clear'd the groun' vor grass to teäke

The pleäce that bore the bremble breäke,

An' drain'd the fen, where water spread,

A-lyèn dead, a beäne to men;

An' built the mill, where still the wheel

Do grind our meal, below the hill;

An' turn'd the bridge, wi' arch a-spread,

Below a road, vor us to tread.

They vound a pleäce, where we mid seek might

The gifts o' greäce vrom week to week;

An' built wi' stwone, upon the hill,

A tow'r we still do call our own;

With bells to use, an' meäke rejaïce,

Wi' giant vaïce, at our good news:

An' lifted stwones an' beams to keep

The raï an' cwold vrom us asleep.

Zoo now mid nwone ov us vorget

so, may

The pattern our vorefathers zet; 
ə:uər fє:ðərz wə:rks

a: ə:I də ðInk əz ə:I də tred ðiəs pe: $\theta$ wi عləmz oivərhed əklımən slo:li $\Lambda p$ vrəm br $\Lambda d_{3}$ b(ə:) I i:zi steps to bro:d(w)uək r rdz ðət a:l ðiəz ro:dz ðət wi: də bru:z wi hosiz Ju:z ar hevi luədz ən hedzIz ban(d)z (h)wor tri:z In ro: də rə:Iz ən gro: ərə:un ðə $\operatorname{lan}(\mathrm{d}) \mathrm{z}$ bi: wərks ðət wi:v əvə:un(d) ərə:t b(ə:)I ə:uər vuərfє:ðərz kjєər ən ðっ:t

ðe: kliərd ðə grə:un vər gra:s tə tjek ðə pljes ðət buər ðə brembəl brjek ən dræInd ðə fєn (h)wər wo:tər spred ələ:Iən ded ə bjen to men ən bilt ðə mıl (h)wər stıl ðə (h)wi:l də grə:ın(d) ə:uər mi:l bilo: ðə hil ən tə:rnd ðə br $\Lambda d_{3}$ wi airt bilo: a ro:d vər $\Lambda \mathrm{s}$ to tred

ðe: vərun(d) ə pljes (h)wər wi: mId si:k ðə gifts ə grjes vrəm wi:k to wi:k ən bilt wi stuən əppn ठə hil ə tə:uər wi: stıl də ka:l əruər o:n wi(ð) belz tə ju:z ən mjek ridzæIs wi dzə:Iənt væIs ət ə:uər gud nju:z on liftıd stuonz on bi:mz to ki:p ðə ræIn ən kuəld vrəm $\Lambda$ s əsli:p zu: nə:u mid nuən əv $\Lambda$ S varget

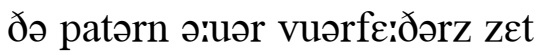


But each be faïn to underteäke

Some work to meäke vor others' gaïn,

That we mid leäve mwore good to sheäre,

may

Less ills to bear, less souls to grieve,

An' when our hands do vall to rest,

It mid be vrom a work a-blest. 
bət i:t $\int$ bi: fæIn tu $\Lambda$ ndərtjek

səm wərrk tə mjek vər $\Lambda$ ðrz gæIn

ðət wi: mid liəv muər gud to $\int j \varepsilon ə r$

les ilz to beər les so:lz to gri:v

ən (h)wen ə'uər han(d)z də va:l tə rest

It mid bi: vrəm ə wərrk əblest 
MY days, wi' wold vo'k all but gone,

An' childern now a-comèn on,

Do bring me still my mother's smiles

In light that now do show my chile's;

An' I've a-sheär'd the wold vo'ks' me'th, shared, mirth

Avore the burnèn Chris'mas he'th, bearth

At friendly bwoards, where feäce by feäce, tables

Did, year by year, gi'e up its pleäce, give

An' leäve me here, behind, to tread

The ground a-trod by wold vo'k dead.

But wold things be a-lost vor new,

An' zome do come, while zome do goo:

As wither'd beech-tree leaves do cling

Among the nesh young buds o' Spring;

An' frettèn worms ha' slowly wound, gnawing

Droo beams the wold vo'k lifted sound, through

An' trees they planted little slips

$\mathrm{Ha}$ ' stems that noo two eärms can clips;

An' grey an' yollow moss do spread

On buildèns new to wold vo'k dead.

The backs of all our zilv'ry hills,

The brook that still do dreve our mills, drive

The roads a-climèn up the brows

O' knaps, a-screen'd by meäple boughs, billocks

Wer all a-mark'd in sheäde an' light

Avore our wolder fathers' zight,

In zunny days, a-gied their hands

For happy work, a-tillèn lands,

That now do yield their childern bread

Till they do rest wi' wold vo'k dead. 
ðə (w)uəld vo:k ded

mə:I de:z wi (w)uəld vo:k a:l bət gon ən tfildərn nə:u ək $\wedge$ mən pn də brin mi: stıl mə:I m^ðərz smə:Ilz

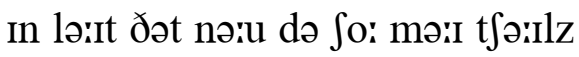

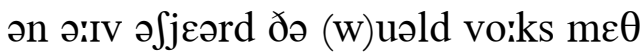
əvuər ðə bə:rnən krisməs he $\theta$ ət fren(d)li buərdz (h)wər fjes b(ə:)I fjes did jiər b(ə:) i jiər gi: $\Lambda$ p its pljes ən liəv mi: hiər bihə:In(d) to tred ðə grə:un(d) ətrod b(ə:)I (w)uəld vo:k ded

bət (w)uəld ðınz bi: əlpst vər nju: ən zım də kım (h)wəril zım də gu: az wıðərd bitt tri: liivz də klın әmpy ठə ne: $j \wedge \mathrm{y} b \Lambda d z$ ə sprin ən fretən wə:rmz hə slo:li wərund dru: bi:mz ðə (w)uəld vo:k liftıd sərund ən tri:z ðe: ple:ntıd litəl slips ha stemz ðət nu: tu: ja:rmz kən klips ən gre: ən jalər mos də spred pn bildənz nju: to (w)uəld vo:k ded

ðə baks əv a:l ə:uər zilvri hılz ðə bruk ðət stıl də dre:v ə:uər milz ðə ro:dz əklımən $\Lambda$ д ð brə:uz ə naps əskri:nd $b($ (ə) I mjepəl bə:uz wər a:l əma:rkt in $\int j \varepsilon d$ ən lə:It әvuər ə:uər (w)uəldər fє:ðərz zə:It In zıni de:z əgi:d ðər han(d)z vər hapi wərrk ətılən $\operatorname{lan}(\mathrm{d}) \mathrm{z}$ ðət nə:u də ji:l(d) ðər t $\int \mathrm{Ild}$ (dərn bred tıl ðe: də rest wi (w)uəld vo:k ded 
But livèn vo'k, a-grievèn on,

Wi' lwonesome love, vor souls a-gone,

Do zee their goodness, but do vind

All else a-stealèn out o' mind;

As air do meäke the vurthest land

Look feäirer than the vield at hand,

An' zoo, as time do slowly pass,

So still's a sheäde upon the grass,

Its wid'nèn speäce do slowly shed

A glory roun' the wold vo'k dead.

An' what if good vo'ks' life o' breath

Is zoo a-hallow'd after death,

That they mid only know above,

Their times o' faïth, an' jaÿ, an' love,

While all the evil time ha' brought

'S a-lost vor ever out o' thought;

As all the moon that idden bright, isn't

'S a-lost in darkness out o' zight;

And all the godly life they led

Is glory to the wold vo'k dead.

If things be zoo, an' souls above

Can only mind our e'thly love, eartbly

Why then they'll veel our kindness drown

The thoughts ov all that meäde em frown.

An' jaÿ o' jaÿs will dry the tear

O' sadness that do trickle here, An' nothèn mwore o' life than love, An' peace, will then be know'd above.

Do good, vor that, when life's a-vled, flown by Is still a pleasure to the dead. 
bət livən vo:k əgri:vən pn

wi luənsəm $1 \Lambda \mathrm{v}$ vər so:lz əgpn

də zi: ðər gudnis bət də və:Ind

a:l cls əstillən ə:ut ə mə:Ind

az æIr də mjєk ðə və:rdist lan(d)

luk fjeərər ðən ðə vi:l(d) ət han(d)

ən zu: əz tə:Im də slo:li pais

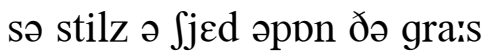

Its wə:Idnən spjes də slo:li $\int \varepsilon d$

ə gluəri rə:un ðə (w)uəld vo:k ded

ən (h)wpt If gud vo:ks lə:If ə bre $\theta$

IZ zu: əhalərd $\varepsilon$ :tər $\mathrm{d} \varepsilon \theta$

ðət ðe: mid o:nli no: əb $\Lambda \mathrm{v}$

ðər tə:Imz ə fæi $\theta$ ən $\mathrm{d} z æ I$ ən $1 \Lambda \mathrm{v}$

(h)wə:Il a:l ði i:vəl tə:Im hə bro:t

s əlpst vər عvər ərut ə ठっ:t

az a:l ðə mu:n ðət Idən brə:It

s əlpst In darrknis ə:ut ə zə:It

ən(d) a:l ðə gpdli lə:If ðe: led

IZ gluəri tə ठə (w)uəld vo:k ded

If ðInz bi: zu: ən so:lz əb $\Lambda \mathrm{v}$

kən o:nli mə:In(d) ə:uər $\varepsilon \theta l i 1 \Lambda \mathrm{v}$

(h)wə:I ðعn ðe:l vi:l ə:uər kə:Indnis drə:un

ðə ठว:ts əv a:l ðət mjed əm frə:un

ən dzæi ə dzæız wil drə:ı ðə tiər

ə sadnis ðət də trikəl hiər

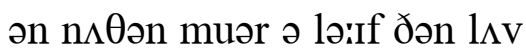

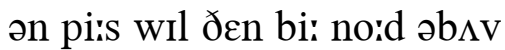

du: gud var ðat (h)wen lə:Ifs əvled

IZ stil ə plezər tə ðə ded 
THERE's noo pleäce I do like so well, As Elem Knap in Culver Dell, Where timber trees, wi' lofty shouds, canopies

Did rise avore the western clouds; An' stan' ageän, wi' veathery tops, A-swaÿèn up in North-Hill Copse. An' on the east the mornèn broke Above a dewy grove o' woak: oak

An' noontide shed its burnèn light

On ashes on the southern height; An' I could vind zome teäles to tell, O' former days in Culver Dell.

An' all the vo'k did love so well The good wold squire o' Culver Dell, folk That used to ramble drough the sheädes through

O' timber, or the burnèn gleädes, An' come at evenèn up the leäze meadow Wi' red-eär'd dogs bezide his knees, An' hold his gun, a-hangèn drough His eärmpit, out above his tooe.

Wi' kindly words upon his tongue, Vor vo'k that met en, wold an' young, armpit, toe

Vor he did know the poor so well 'S the richest vo'k in Culver Dell.

An' while the woäk, wi' spreadèn head,

Did sheäde the foxes' verny bed;

An' runnèn heäres, in zunny gleädes,

Did beät the grasses' quiv'rèn' bleädes; An' speckled pa'tridges took flight In stubble vields a-feädèn white; 
kılvər del ən(d) ðə skwə:ıวr

ðərz nu: pljes ə:I də lə:Ik sə wel

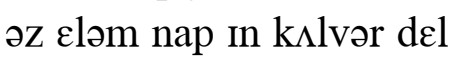

(h)wər timbər tri:z wi lpfti fərudz

did rə:IZ əvuər ðə westərn klə:udz

ən stan əgjen wi veðri tpps

əswæiən $\Lambda$ p In np$\theta h ı l ~ k p p s$

ən pn ði isst ðə ma:rnən bro:k

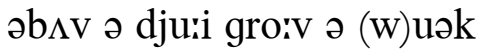

ən nu:ntəitd $\int \varepsilon d$ its bərrnən lə:It

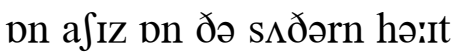

ən ə:I kud və:In(d) zəm tjelz to tel

ə fa:rmər de:z in kılvər del

ən a:l ðə vo:k did $1 \Lambda \mathrm{v}$ sə wel

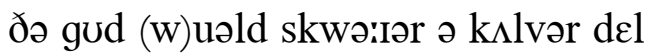

ðət juist tə rambəl dru: ðə $\int j \varepsilon d z$

ə tımbər ar ðə bə:rnən gljedz

ən k $\Lambda \mathrm{m}$ ət i:vmən $\Lambda \mathrm{p}$ ðə liəz

wi rediərd dpgz bizə:Id (h)Iz ni:z

ən huəld (h)Iz g $\Lambda$ n əhayən dru:

(h)IZ ya:rmpit $ə$ 'ut $\partial b \Lambda v(h)$ Iz tu:

wi kə:In(d)li wərrdz əppn (h)Iz t $\mathrm{y}$ y

vər vo:k dət met ən (w)uəld ən j $\Lambda$ y

var hi: did no: ðə pu(:)ər sə wel

$\mathrm{z}$ ðə ritfist vo:k in kılvər del

ən (h)wəril ðə (w)uək wi spredən hed

did Jjed ðə foksız vərrni bed

ən rınən hjeərz In zıni gljedz

did biət ðə graisız kwivrən bljedz

ən spekəld pe:tridzIz tuk flə:it

In st $\lrcorner$ bəl vi:l(d)z əfjedən (h)wə:It 
Or he could zee the pheasant strut

In sheädy woods, wi' païnted cwoat;

Or long-tongued dogs did love to run

Among the leaves, bezide his gun;

We didden want vor call to dwell

didn't

At hwome in peace in Culver Dell.

But now I hope his kindly feäce

Is gone to vind a better pleäce;

But still, wi' vo'k a-left behind

He'll always be a-kept in mind,

Vor all his springy-vooted hounds

Ha' done o' trottèn round his grounds,

An' we have all a-left the spot,

To teäke, a-scatter'd, each his lot;

An' even Father, lik' the rest,

Ha' left our long vorseäken nest;

An' we should vind it sad to dwell,

Ageän at hwome in Culver Dell.

The aïry mornèns still mid smite

may

Our windows wi' their rwosy light,

An' high-zunn'd noons mid dry the dew

On growèn groun' below our shoe;

The blushèn evenèn still mid dye,

Wi' viry red, the western sky;

fiery

The zunny spring-time's quicknèn power

Mid come to oben leaf an' flower;

An' days an' tides mid bring us on

Woone pleasure when another's gone.

one

But we must bid a long farewell

To days an' tides in Culver Dell. 
ar hi: kud zi: ðə fezənt strıt

In $\int j \varepsilon d i$ wodz wi pæintıd kuət

ar loyt $\Lambda$ yd dogz did $1 \Lambda \mathrm{v}$ to r $\Lambda \mathrm{n}$

әmpy ðə liivz bızə:Id (h)Iz g $\Lambda$ n

wi: didən wont vər ka:l tə dwel

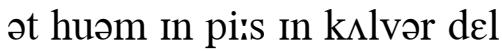

bət nə:u ə:I ho:p (h)Iz kə:In(d)li fjes

IZ gpn to və:In(d) ə betər pljes

bət stıl wi vo:k əleft bihə:In(d)

hi:l a:lwe:z bi: əkept in mə:In(d)

var a:l (h)Iz sprinivutid hə:un(d)z

hə d $\Lambda$ n ə trotən rə:un(d) (h)Iz grə:un(d)z

ən wi: həv a:l əleft ðə sppt

to tjek əskatərd itt (h)Iz lpt

ən iivən fe:ðər lik ðə rest

hə left ə:uər lpy varsjekən nest

ən wi: Sud və:In(d) It sad to dwel

əgjen ət huəm in kılvər del

ði æıri ma:rnənz stıl mid smə:It

ə:uər windərz wi ðər ruəzi lə:It

ən hə:Izınd nu:nz mid drə:I ðə dju:

pn gro:ən grə:un bilo: ə:uər $\int u$ :

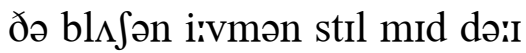

wi və:Iəri red ðə westərn skə:I

ðə z^ni sprıntə:Imz kwıknən pə:uər

mid kım tu o:bən liif ən flə:uər

ən de:z ən tə:Idz mid brin əs pn

(w)u:n plezər (h)wen ən^ðərz gpn

bət wi: məst bid ə lpy fjearwel

tə de:z ən tə:Idz in kılvər del 
How dear's the door a latch do shut, An' geärden that a hatch do shut,

Where vu'st our bloomèn cheäks ha' prest wicket-gate first

The pillor ov our childhood's rest;

Or where, wi' little tooes, we wore toes

The paths our fathers trod avore;

Or clim'd the timber's bark aloft,

Below the zingèn lark aloft,

The while we heärd the echo sound

Drough all the ringèn valley round.

through

A lwonesome grove o' woak did rise, oak

To screen our house, where smoke did rise,

A-twistèn blue, while yeet the zun yet

Did langthen on our childhood's fun;

An' there, wi' all the sheäpes an' sounds

O' life, among the timber'd grounds, The birds upon their boughs did zing, An' milkmailds by their cows did zing, Wi' merry sounds, that softly died, A-ringèn down the valley zide.

By river banks, wi' reeds a-bound, An' sheenèn pools, wi' weeds a-bound, shining The long-neck'd gander's ruddy bill To snow-white geese did cackle sh'ill; loudly An' stridèn peewits heästen'd by, O' tiptooe wi' their screamèn cry; An' stalkèn cows a-lowèn loud, An' struttèn cocks a-crowèn loud, Did rouse the echoes up to mock mimic Their mingled sounds by hill an' rock. 


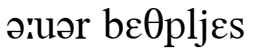

hə:u diərz ðə duər ə lat $\int \mathrm{d} ə \int \Lambda \mathrm{t}$ ən gjairdən ठət ə hat $\int \mathrm{d} ə \int \Lambda \mathrm{t}$

(h)wər vıst ə:uər blu:mən t fiəks hə prest

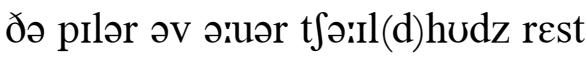
ar (h)wər wi litəl tu:z wi: wuər

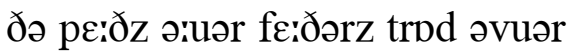
ar klimd ðə timbərz bairk əlpft bilo: ðə zingən la:rk əlpft ðə (h)wə:ıl wi: hiərd ði عko: sə:un(d) dru: a:l ðə rijən vali rə:un(d)

ə luənsəm gro:v ə (w)uək did rə:Iz to skri:n ə:uər hə:us (h)wər smo:k did rə:Iz ətwistən blu: (h)wə:Il (j)i:t ðə zムn

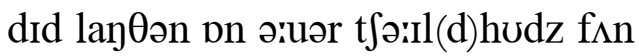
ən ðər wi a:l ðə $\int j \varepsilon p s$ ən sə:un(d)z ə lə:If əmpy ठə timbərd grə:un(d)z ðə bə:rdz әppn ðər bə:uz did zIn ən milkmæidz b(ə:)I ðər kə:uz did zin wi meri sə:un(d)z dət spf(t)li də:Id ərinən də:un ðə vali zə:Id

b(ə:)I rivər bayks wi ri:dz əbə:un(d) ən Ji:nən pu:lz wi wi:dz əbə:un(d) ðə lpynekt gandərz rıdi bil to sno:(h)wə:It gi:s did kakəl $\int_{\mathrm{I}} \mathrm{l}$ ən strəitdən pirwits hjesənd bə:I ə tiptu: wi ðər skri:mən krə:I ən ste:kən kə:uz əlo:ən lə:ud ən strıtən kpks əkro:ən lə:ud did rə:uz ði عko:z $\Lambda \mathrm{p}$ tə $\mathrm{mpk}$ ðər mingəld sə:un(d)z b(ə:)I hil ən rok 
The stars that clim'd our skies all dark, Above our sleepèn eyes all dark, An' zuns a-rollèn round to bring

The seasons on, vrom Spring to Spring, $\mathrm{Ha}$ ' vled, wi' never-restèn flight,

Drough green-bough'd day, an' dark-tree'd night; flown Till now our childhood's pleäces there, Be gaÿ wi' other feäces there, An' we ourselves do vollow on

Our own vorelivers dead an' gone. ancestors 
ðə sta:rz ðət klımd ə:uər skə:Iz a:l da:rk əb $\Lambda$ v ə:uər sli:pən ə:Iz a:l da:rk

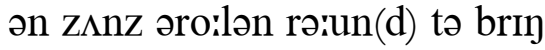
ðə si:zənz pn vrəm sprin tə sprin hə vled wi nevər restən flə:It dru: gri:nbə:ud de: on darktri:d nə:It tıl nə:u ə:uər tfəril(d)hudz pljesız ðər bi: gæı wi $\Lambda$ ðr fjesız ðər ən wi: ə'uərzムvz də vpli pn ə:uər o:n vuərlıvərz ded ən gpn 
WHEN Pentridge House wer still the nest

O' souls that now ha' better rest,

Avore the viër burnt to ground

fire

His beams an' walls, that then wer sound,

'Ithin a nail-bestudded door,

An' passage wi' a stwonèn vloor,

stone

There spread the hall, where zun-light shone

In drough a window freäm'd wi' stwone.

through

A clavy-beam o' sheenèn woak

mantlepiece, shining oak

Did span the he'th wi' twistèn smoke, bearth

Where fleämes did shoot in yollow streaks,

Above the brands, their flashèn peaks;

An' aunt did pull, as she did stand

O'-tip-tooe, wi' her lifted hand,

A curtain feäded wi' the zun,

Avore the window freäm'd wi' stwone.

When Hwome-ground grass, below the moon, bome-field

Wer damp wi' evenèn dew in June,

An' aunt did call the maïdens in

Vrom walkèn, wi' their shoes too thin,

They zot to rest their litty veet

Upon the window's woaken seat, sat, light

An' chatted there, in light that shone

In drough the window freäm'd wi' stwone.

An' as the seasons, in a ring,

Roll'd slowly roun' vrom Spring to Spring,

An' brought em on zome holy-tide,

When they did cast their tools azide; 
ðə windər frjemd wi stuən

(h)wen pentridz hə:us wər stıl ðə nest ə so:lz ðət nə:u ha betər rest əvuər ðə və:ıər bə:rnt to grə:un(d) (h)Iz bi:mz ən wa:lz ðət ðعn wər sə:un(d) IðIn ə næIlbist $\Lambda$ did duər ən pasidz wi ə stuənən vluər ðər spred ðə ha:l (h)wər z^nlə:It $\int p n$ In dru: ə windər frjemd wi stuən

ə klavibi:m ə Ji:nən (w)uək did span ðə he $\theta$ wi twistən smo:k (h)wər fljemz did fut in jalər stri:ks

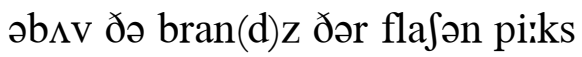
ən ع:nt did pul əz Ji: did stan(d) ətiptu: wi (h)ər liftıd han(d) ə kə:rtən fjedid wi ðə zムn əvuər ðə windər frjemd wi stuən

(h)wen huəmgrə:un(d) gra:s bilo: ðə mu:n wər damp wi i:vmən dju: in dzuin ən ع:nt did ka:l ðə mæidənz in vrəm we:kən wi ðər Ju:z tu: ðIn ðe: zat to rest ðər liti vi:t əppn ठə windərz (w)uəkən si:t

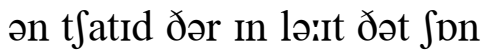
In dru: ðə windər frjemd wi stuən

ən az ðə si:zənz In ə rıy ro:ld slo:li rə:un vrom sprin to sprin ən bro:t əm pn z^m ho:litə:Id (h)wen ðe: dıd ka:st ðər tu:lz əzə:Id 
How glad it meäde em all to spy

In Stwonylands their friends draw nigh,

As they did know em all by neäme

Out drough the window's stwonèn freäme.

$\mathrm{O}$ evenèn zun, a-ridèn drough

The sky, vrom Sh'oton Hill o' blue,

To leäve the night a-broodèn dark

At Stalbridge, wi' its grey-wall'd park;

Small jay to me the vields do bring,

Vor all their zummer birds do zing,

Since now thy beams noo mwore do fleäme

In drough the window's stwonèn freäme. 
hə:u glad it mjed əm ail tə spə:I

In stuənilan(d)z ðər fren(d)z dre: nə:I

əz ðe: did no: əm a:l b(ə:) I njem

ə:ut dru: ðə windərz stuənən frjem

o: iivmən zムn ərə:Idən dru:

ðə skə:I vrəm $\int$ pdən hil ə blu:

tə liəv ðə nə:It əbru:dən da:rk

ot ste:br $\Lambda$ d3 wi its greiwaild pairk

sma:l dzæi tə mi: ठə vi:l(d)z də brin

vər a:l ðər z^mər bərrdz də zIy

sins nə:u ðə:I bi:mz nu: muər də fljem

In dru: ðə windərz stuənən frjem 
OH! aye! the spring 'ithin the leäne, A-leäden down to Lyddan Brook;

An' still a-nesslèn in his nook,

As weeks do pass, an' moons do weäne.

wane

Nwone the drier,

Nwone the higher,

Nwone the nigher to the door

Where we did live so long avore.

An' oh! what vo'k his mossy brim

folk

Ha' gathered in the run o' time!

The wife a-blushèn in her prime;

The widow wi' her eyezight dim;

Maïdens dippèn,

Childern sippèn,

Water drippèn, at the cool

Dark wallèn ov the little pool.

walls

Behind the spring do lie the lands

My father till'd, vrom Spring to Spring,

Awäitèn on vor time to bring

The crops to paÿ his weary hands.

Wheat a-growèn,

Beäns a-blowèn,

Grass vor mowèn, where the bridge

Do leäd to Ryall's on the ridge.

But who do know when liv'd an' died

The squier o' the mwoldrèn hall;

mouldering

That lined en wi' a stwonèn wall,

it, stone

An' steän'd so cleän his wat'ry zide?

paved with stone 
ðə wə:tərsprın In ðə ljen

о: æı ðə sprı̈ Iðın ðə ljen əliədən də;un tə lidən bruk ən strl əneslən in (h) Iz nuk əz wi(:)ks də pa:s ən mu:nz də wjen nuən ðə drə:ıər nuən ðə hə:ıər nuən ðə nə:ıər tə ðə duər (h)wər wi: dıd lıv sə lpy əvuər วn o: (h)wpt vo:k (h)Iz mpsi brim hə gaðərd in ðə rAn ə tə:Im

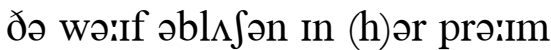
ðə widər wi (h)ər ə:Izə:It dim mæidənz dipən t $\int$ Ildərn sipən wo:tər dripən ət ðə ku:l da:rk wa:lən əv ðə litəl pu:l

bihə:In(d) ðə sprin də lə:I ðə $\operatorname{lan}(\mathrm{d}) \mathrm{z}$ mə:I fe:ðər tıld vrəm sprin to sprin əwæitən pn vər tə:Im to brin ðə krops tə pæI (h)IZ wiəri han(d)z

(h)wi:t əgro:ən biənz əblo:ən gra:s vər mo:ən (h)wər ðə br $\Lambda \mathrm{d} 3$ də liəd tə rə:Ia:lz pn ðə $\mathrm{r} \Lambda \mathrm{d} 3$

bət hu: də no: (h)wen livd ən də:Id ðə skwə:ıər ə ðə muəldrən ha:l ðət lə:Ind ən wi ə stuənən wa:l ən stiənd sə kliən (h)Iz wo:tri zə:Id 
We behind en,

bim

Now can't vind en,

it

But do mind en, an' do thank

remember

His meäker vor his little tank. 
wi: bihə:In(d) ən

nə:u ke:nt və:In(d) ən

b $\Lambda$ t də mə:In(d) ən ən də $\theta$ ayk

(h)Iz mjekər vər (h)Iz litəl tạk 
IF theäse day's work an' burnèn sky

'V'a-zent hwome you so tired as I,

Let's zit an' rest 'ithin the screen

O' my wold bow'r upon the green;

old

Where I do goo myself an' let

The evenèn aiër cool my het, beat

When dew do wet the grasses bleädes,

A-quiv'rèn in the dusky sheädes.

There yonder poplar trees do plaÿ

Soft music, as their heads do swäy,

While wind, a-rustlèn soft or loud,

Do stream ageän their lofty sh'oud;

canopy

An' seem to heal the ranklèn zore

My mind do meet wi' out o' door,

When I've a-bore, in downcast mood,

Zome evil where I look'd vor good.

O' they two poplars that do rise

So high avore our naïghbours' eyes,

A-zet by gramfer, hand by hand,

Grandpa

Wi' grammer, in their bit o' land;

Grandma

The woone upon the western zide

one

Wer his, an' woone wer grammer's pride,

An' since they died, we all do teäke

Mwore ceäre o'm vor the wold vo'k's seäke.

of them, old folk's

An' there, wi' stems a-growèn tall

trunks

Avore the houses mossy wall,

The while the moon ha' slowly past

The leafy window, they've a-cast 
ðə ppplərz

If ðiəs de:z wərrk ən bərrnən skə:I v əzent huəm ju: sə tə:ıərd əz ə:I lets zit ən rest ıðın ðə skri:n ə mə:I (w)uəld bə:uər əppn ðə gri:n (h)wər ə:I də gu: mə:Izムf ən let ði i:vmən æıər ku:l mə:I het (h)wen dju: də wet ðə gra:sız bljedz əkwIvrən in ðə d $\Lambda$ ski $\int j \varepsilon d z$

ðər jandər ppplər tri:z də plæI spft mju:zık əz ðər hedz də swæI (h)wə:Il win(d) ərıslən spft ər lə:ud

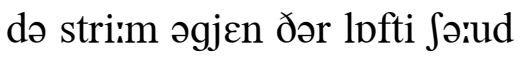
ən si(:)m tə hi:l ðə rayklən zuər mə:I mə:In(d) də mi(:)t wi ə:ut ə duər (h)wen ə:IV əbuər In dərunkaist mud zım i:vəl (h)wər ə:I lukt vər gud

o: ðe: tu: ppplərz ðət də rə:IZ sə hə:I əvuər ə:uər næibərz ə:Iz əz\&t b(ə:)I gramfər han(d) b(ə:)I han(d) wi gramər In ठər bit ə lan(d) ðə (w)u:n әppn ðə westərn zə:Id wər (h)Iz ən (w)u:n wər gramərz prə:Id ən sins ðe: də:Id wi: a:l də tjek muər kjeər o:m vər ðə (w)uəld vo:ks sjek

ən ðər wi stemz əgro:ən ta:l əvuər ðə hə:usız mpsi wa:l ðə (h)wəril ðə mu:n hə slo:li pa:st ðə li:fi windər ðe:v əka:st 
Their sheädes 'ithin the window peäne;

shadows

While childern have a-grown to men,

An' then ageän ha' left their beds,

To bear their childern's heavy heads. 
ðər $\int j \varepsilon d z$ Iðın ðə windər pjen

(h)wə:Il t fildərn həv əgro:n to men

ən ðعn əgjen hə left ðər bedz

to beər ðər t fildərnz hevi hedz 
No! Jenny, there's noo pleäce to charm

My mind lik' yours at Woakland farm,

A-peärted vrom the busy town,

separated

By longsome miles ov airy down,

Where woonce the meshy wall did gird

once, mossy

Your flow'ry geärden, an' the bird

Did zing in zummer wind that stirr'd

The spreädèn linden on the lawn.

An' now ov all the trees wi' sheädes shadows

A-wheelèn round in Blackmwore gleädes,

There's noo tall poplar by the brook,

Nor elem that do rock the rook,

Nor ash upon the shelvèn ledge,

Nor low-bough'd woak bezide the hedge, sloping

Nor withy up above the zedge, oak willow

So dear's thik linden on the lawn. that

Vor there, o' zummer nights, below

The wall, we zot when air did blow, sat

An' sheäke the dewy rwose a-tied

Up roun' the window's stwonèn zide.

stone

An' while the carter rod' along rode

A-zingèn, down the dusky drong, lane

There you did zing a sweeter zong

Below the linden on the lawn.

An' while your warbled ditty wound

Drough plaÿsome flights o' mellow sound,

The nightèngeäle's sh'ill zong, that broke through

The stillness ov the dewy woak, melodious oak 
ðə lindən pn ðə le:n

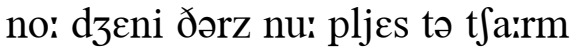

mə:I mə:in(d) lik ju(:)ərz ət (w)uəklən(d) fa:rm

әpja:rtıd vrəm ðə bızi tə:un

b(ə:)I lpysəm mə:Ilz əv æIri də:un

(h)wər (w)u:ns ðə me: ji wa:l did gə:rd

jər flə:uri gja:rdən ən ðə bə:rd

did zIy In z^mər win(d) ðət stə:rd

ðə spredən lindən pn ðə le:n

ən nə:u əv a:l ðə tri:z wi $\int j \varepsilon d z$

ə(h)willən rə:un(d) In blakmuər gljedz

ðərz nu: ta:l ppplər b(ə:)I ðə bruk

nar عləm ðət də rok ðə ruk

nar a 2 əppn ðə $\int \varepsilon l v ə n ~ l \varepsilon d 3$

nar lo:bə:ud (w)uək bizə:Id ðə hedz

nar wıði $\Lambda \mathrm{p} ә \mathrm{~b} \Lambda \mathrm{v}$ ðə zedz

sə diərz ðrk lindən pn ðə le:n

var ðər ə zムmər nə:Its bilo:

ðə wa:l wi: zat (h)wen æIr did blo:

ən Sjek ðə dju:i ruəz ətə:Id

$\Lambda p$ rə:un ðə windərz stuənən zə:Id

ən (h)wə:Il ðə ka:rtər rod əlpy

əzıngən də:un ðə d $\Lambda$ ski drpy

ðər ju: did zin ə swi(:)tər zpy

bilo: ðə lindən pn ðə le:n

ən (h)wə:Il jər wa:rbəld diti wə:un(d)

dru: plæisəm flə:its ə melər sə:un(d)

ðə nə:Itəngjelz $\int \mathrm{Il}$ zpy ðət bro:k

ðə stılnıs əv ðə djuii (w)uək 
Rung clear along the grove, an' smote

To sudden stillness ev'ry droat;

throat

As we did zit, an' hear it float

Below the linden on the lawn.

Where dusky light did softly vall

'Ithin the stwonèn-window'd hall, stone-

Avore your father's blinkèn eyes,

His evenèn whiff o' smoke did rise,

An' vrom the bedroom window's height

Your little John, a-cloth'd in white,

An' gwain to bed, did cry "good night"

going

Towards the linden on the lawn.

But now, as Dobbin, wi' a nod

Vor ev'ry heavy step he trod,

Did bring me on, to-night, avore

The geäbled house's pworchèd door,

Noo laughèn child a-cloth'd in white,

Look'd drough the stwonèn window's light,

An' noo vaïce zung, in dusky night,

Below the linden on the lawn.

An' zoo, if you should ever vind

so

My kindness seem to grow less kind,

An' if upon my clouded feäce

My smile should yield a frown its pleäce,

Then, Jenny, only laugh an' call

My mind 'ithin the geärden wall,

Where we did plaÿ at even-fall,

Below the linden on the lawn. 
r $\Lambda$ y kliər əlpy ðə gro:v ən smo:t to s $\Lambda$ dən stilnis evri dro:t əz wi: did zit on hior it flo:t bılo: ðə lindən pn ðə le:n

(h)wər d $\Lambda$ ski lə:ıt did spf(t)li va:l IðIn ðə stuənənwindərd ha:l әvuər jər fє:ðərz blinkən ə:Iz (h)Iz iivmən (h)wif ə smo:k did rə:Iz ən vrəm ðə bedru:m windərz hə:it jər litəl dzan əklo:ðd in (h)wə:it ən gwæin to bed did krə:I gud nə:It təwa:rdz ðə lindən pn ðə le:n

bət nə:u əz dpbın wi ə npd vər عvri hevi step hi: trod did brin mi: pn tənə:It əvuər ðə gjebəld hə:usız puərt Id duər nu: le:fən tfəril(d) əklo:ðd in (h)wə:It lukt dru: ðə stuənən windərz lə:it ən nu: væIS z^y In d $\Lambda$ ski nə:It bilo: ðə lindən pn ðə le:n

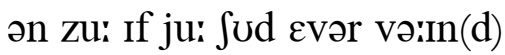
mə:I kə:Indnis si(:)m tə gro: les kə:In(d) ən If əppn mə:I klə:udid fjes mə:I smə:Il $\int u d$ ji:l(d) ə frərun its pljes ðєn dzeni o:nli le:f ən ka:l mə:I mə:In(d) ıðın ðə gja:rdən wa:l (h)wər wi: did plæı ət i:vənfa:l bilo: ðə lindən pn ðə le:n 
OUR ABODE IN ARBY WOOD

THOUGH ice do hang upon the willows

Out bezide the vrozen brook,

An' storms do roar above our pillows,

Drough the night, 'ithin our nook;

through

Our evenèn he'th's a-glowèn warm, hearth's

Drough wringèn vrost, an' roarèn storm.

Though winds mid meäke the wold beams sheäke,

In our abode in Arby Wood.

may, old

An' there, though we mid hear the timber

Creake avore the windy rain;

An' climèn ivy quiver, limber,

pliant

Up ageän the window peäne;

Our merry vaïces then do sound,

In rollèn glee, or dree-vaïce round;

three-

Though wind mid roar, 'ithout the door,

Ov our abode in Arby Wood. 
ə:uər əbo:d in a:rbi wud

ðo: ə:Is də hay əppn ðə wilərz ə:ut bizə:Id ðə vro:zən bruk ən sta:rmz də ruər əb $\Lambda$ v ə'uər pilərz dru: ðə nə:It Iðın ə:uər nuk ə:uər iivmən heӨs əglo:ən wa:rm dru: ringən vrost ən ruərən sta:rm

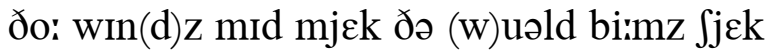
In ə:uər əbo:d in a:rbi wud

ən ðər ðo: wi: mId hiər ðə tımbər kre:k əvuər ðə wIndi ræIn ən klimən ə:Ivi kwivər limbər $\Lambda p$ әgjen ðə windər pjen ə:uər meri væIsIz ðદn də sə:un(d) In ro:lən gli: ar dri:væis rə:un(d) ðo: $\operatorname{win}(d)$ mId ruər Iðə:ut ठə duər əv ə:uər əbo:d In a:rbi wud 
SLOW TO COME, QUICK AGONE

AH! there's a house that I do know

Besouth o' yonder trees,

Where northern winds can hardly blow

But in a softest breeze.

An' there woonce sounded zongs an' teäles

once

Vrom vaïce o' maïd or youth,

An' sweeter than the nightèngeäle's

Above the copses lewth.

shelter

How swiftly there did run the brooks,

How swift wer winds in flight,

How swiftly to their roost the rooks

Did vlee o'er head at night.

Though slow did seem to us the peäce

O' comèn days a-head,

That now do seem as in a reäce

Wi' air-birds to ha' vled.

flown 
slo: to kım kwik əgin

a: ðərz ə hə:us ðət ə:I də no:

bisə:u $\theta$ ə jandər tri:z

(h)wər na:rðərn win(d)z kən ha:rdli blo:

bət in a spftist bri:z

ən ठər (w)urns sə:un(d)rd zpyz ən tjelz

vrəm væIs ə mæid ar ju: $\theta$

ən swi(:)tər ðən ðə nə:Itəngjelz

əb $\Lambda$ v ðə kppsız lu: $\theta$

hə:u swIf(t)li ðər did r $\wedge$ n ðə bruks

hə:u swift wər win(d)z in flə:it

hə:u swIf(t)li tə ðər ru:st ðə ruks

did vli: orrhed ət nə:It

ðо: slo: did si(:)m tu $\Lambda$ s ðə pjes

ə kımən de:z əhed

ðət nə:u də si(:)m əz in ə rjes

wi æIrbərdz tu hə vled 
'Tis zome vo'ks jaÿ to teäke the road,

folk's joy

An' goo abro'd, a-wand'rèn wide, out and about

Vrom shere to shere, vrom pleäce to pleäce, shire to shire

The swiftest peäce that vo'k can ride.

But I've a jaÿ 'ithin the door,

Wi' friends avore the vier-zide.

An' zoo, when winter skies do lour,

An' when the Stour's a-rollèn wide,

Drough bridge-voot rails, a-païnted white,

through

To be at night the traveller's guide,

Gi'e me a pleäce that's warm an' dry, give

A-zittèn nigh my vier-zide.

Vor where do love o' kith an' kin,

At vu'st begin, or grow an' wride,

Till souls a-lov'd so young, be wold,

first, spread

old

Though never cwold, drough time nor tide,

But where in me'th their gather'd veet

mirth

Do often meet - the vier-zide.

If, when a friend ha' left the land,

I shook his hand a-most wet-eyed,

I velt too well the ob'nèn door

opening

Would leäd noo mwore where he did bide,

An' where I heärd his vaïce's sound,

In me'th around the vier-zide.

As I've a-zeed how vast do vall seen, fast
mouldering, old folk's

The mwold'rèn hall, the wold vo'ks pride, 
ðə və:ıərzə:Id

tIZ z^m vo:ks dzæı tə tjek ठə ro:d ən gu: əbro:d əwpndrən wə:Id vrəm fiər to fiər vrəm pljes to pljes ðə swiftıst pjes ðət vo:k kən rə:Id bət ə:IV ə dzæı IðIn ðə duər wi fren(d)z əvuər ðə və:ıərzə:Id

ən zu: (h)wen wintər skə:Iz də lə:uər ən (h)wen ðə stə:uərz əro:lən wə:Id dru: brıdzvot ræIlz əpæIntId (h)wə:It tə bi: ət nə:It ðə travələrz gə:Id gi: mi: ə pljes ðəts wa:rm ən drə:I əzitən nə:I mə:I və:Iərzə:Id

$\operatorname{var}(\mathrm{h}) w ə r$ də $1 \Lambda \mathrm{v}$ ə kI $\theta$ ən kın at v $\Lambda$ st bigin ar gro: ən rə:Id tIl so:lz əlıvd sə j^y bi: (w)uəld ðo: nevər kuəld dru: tə:Im nər tə:Id bət (h)wər in me $\theta$ ðər gaðərd vi:t du: pfən mi:t ðə və:Iərzə:Id

If (h)wen ə fren(d) hə left ðə lan(d) ə:I Juk (h)Iz han(d) a:məst wetə:Id ə:I velt tu: wel ði o:bnən duər wud liəd nu: muər (h)wər hi: did bə:Id ən (h)wər ə:I hiərd (h)Iz væIsIz sə:un(d) in $m \varepsilon \theta$ ərə:un(d) ðə və:Iərzə:Id

az ə:Iv əzi:d hə:u va:st də va:l ðə muəldrən ha:l ðə (w)uəld vo:ks prə:Id 
Where merry hearts wer woonce a-ved

Wi' daily bread, why I've a-sigh'd,

To zee the wall so green wi' mwold,

An' vind so cwold the vier-zide.

An' Chris'mas still mid bring his me'th

may, its mirth

To ouer he'th, but if we tried our hearth

To gather all that woonce did wear once

Gay feäces there! Ah! zome ha' died, An' zome be gone to leäve wi' gaps O' missèn laps, the vier-zide.

But come now, bring us in your hand, A heavy brand o' woak a-dried, oak

To cheer us wi' his het an' light, beat

While vrosty night, so starry-skied,

Do gather souls that time do speäre

To zit an' sheäre our vier-zide. 
(h)wər meri ha:rts wər (w)unns əved wi de:li bred (h)wə:I əIIV əsə:Id tə zi: ठə wa:l sə gri:n wi muəld ən və:In(d) sə kuəld ðə və:Iərzə:Id

ən krisməs stil mid brin (h)Iz me $\theta$ tu ə:uər he $\theta$ bət If wi: trə:Id tə gaðər a:l ðət (w)u:ns did weər

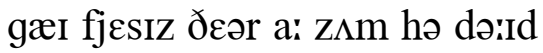

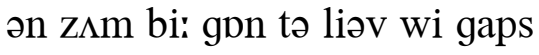
ə misən laps ðə və:ıərzə:Id bət kım nə:u brin əs In jər han(d) ə hevi bran(d) ə (w)uək ədrə:Id to tfiər əs wi (h)rz het ən lə:it (h)wə:Il vrosti nə:It sə sta:riskə:Id də gaðər so:lz ðət tə:Im də spjeər to zit ən $\int j \varepsilon ə r$ ə:uər və:ıərzə:Id 


\section{KNOWLWOOD}

I DON'T want to sleep abrode, John, away from bome

I do like my hwomeward road, John;

An' like the sound o' Knowlwood bells the best.

Zome would rove vrom pleäce to pleäce, John,

Zome would goo from feäce to feäce, John,

But I be happy in my hwomely nest;

An' slight's the hope vor any pleäce bezide,

To leäve the plaïn abode where love do bide.

Where the shelvèn knap do vall, John,

sloping billock

Under trees a-springèn tall, John;

'Tis there my house do show his sheenèn zide,

shining

Wi' his walls vor ever green, John,

Under ivy that's a screen, John,

Vrom wet an' het, an' ev'ry changèn tide,

beat

An' I do little ho vor goold or pride,

care

To leäve the plaïn abode where love do bide.

There the bendèn stream do flow, John,

By the mossy bridge's bow, John;

$\operatorname{arch}$

An' there the road do wind below the hill;

There the miller, white wi' meal, John,

Deafen'd wi' his foamy wheel, John,

Do stan' o' times a-lookèn out o' mill:

The while 'ithin his lightly-sheäken door,

His wheatèn flour do whiten all his floor.

When my daily work's a-done, John,

At the zettèn o' the zun, John,

An' I all day 've a-plaÿ'd a good man's peärt,

I do vind my ease a-blest, John,

While my conscience is at rest, John; 
no:lwud

ə:I do:nt wpnt to sli:p əbro:d dzan

ə:I də lə:ik mə:I huəmwərd ro:d dzan

ən lə:ı ðə sə:un(d) ə no:lwud belz ðə best

z^m wud ro:v vrəm pljes to pljes dzan

$\mathrm{z} \Lambda \mathrm{m}$ wud gu: vrəm fjes to fjes dzan

bət ə:I bi: hapi in mə:I huəmli nest

ən slə:its ðə ho:p vər عni pljes bizə:Id

tə liəv ðə plæIn əbo:d (h)wər $1 \Lambda v$ də bə:Id

(h)wər ðə $\int \varepsilon l v ə n$ nap də va:l dzan

$\Lambda$ ndər trizz əsprinən ta:l dzan

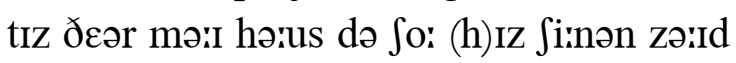

wi (h)Iz wa:lz vər evər griin dzan

$\Lambda$ ndər ə:Ivi ðəts ə skrin dzan

vrəm wet ən het ən evri tfandzən tə:Id

ən ə:I də litəl ho: vər guild ər prə:Id

tə liəv ðə plæIn əbo:d (h)wər $1 \Lambda \mathrm{v}$ də bə:Id

ðər ðə bendən stri:m də flo: dzan

b(ə:)I ðə mpsi brıdzIz bo: dzan

ən ठər ðə ro:d də wə:In(d) bilo: ðə hıl

ðər ðə milər (h)wə:it wi mi:l dzan

defənd wi (h)rz formi (h)will dzan

də stan ə tə:Imz əlukən ə:ut ə mil

ðə (h)wə:Il ıðın (h)Iz lə:Itlijjekən duər

(h)Iz (h)wi:tən flə:uər də (h)wə:təon a:l (h)Iz fluər

(h)wen mə:I de:li wərrks əd $\Lambda$ dzan

ət ðə zctən ə ðə z^n dzan

ən ə:I a:l de: v əplæid ə gud manz pjart

ə:I də və:In(d) mə:I i:z əblest dzan

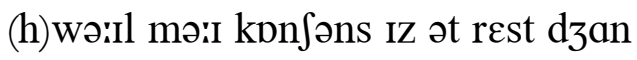


An' while noo worm's a-left to fret my heart;

gnaw

An' who vor finer hwomes o' restless pride,

Would pass the plaïn abode where peace do bide?

By a windor in the west, John,

There upon my fiddle's breast, John,

The strings do sound below my bow's white heäir;

While a zingèn drush do swaÿ, John,

thrush

Up an' down upon a spraÿ, John,

An' cast his sheäde upon the window square;

shadow

Vor birds do know their friends, an' build their nest,

An' love to roost, where they can live at rest.

Out o' town the win' do bring, John,

Peals o' bells when they do ring, John,

An' roun' me here, at hand, my ear can catch

The maïd a-zingèn by the stream, John,

Or carter whislèn wi' his team, John,

Or zingèn birds, or water at the hatch;

An' zoo wi' sounds o' vaïce, an' bird an' bell,

wicket-gate

Noo hour is dull 'ithin our rwosy dell.

An' when the darksome night do hide, John,

Land an' wood on ev'ry zide, John;

An' when the light's a-burnèn on my bwoard,

table

Then vor pleasures out o' door, John,

I've enough upon my vloor, John:

My Jenny's lovèn deed, an' look, an' word,

An' we be lwoth, lik' culvers zide by zide,

doves

To leäve the plaïn abode where love do bide. 
ən (h)wə:Il nu: wə:rmz əleft tə fret mə:I ha:rt ən hu: vər fə:Inər huəmz ə res(t)lis prə:Id wud pa:s ðə plæIn əbo:d (h)wər pi:s də bə:Id

b(ə:)I ə windər In ðə west dzan ðər əppn mə:I fidəlz brest dzan ðə strinz də sə:un(d) bilo: mə:I bo:z (h)wə:It hjeər (h)wə:Il ə zingən $\mathrm{dr} \Lambda \int \mathrm{d}$ swæi dzan $\Lambda p$ ən də:un əppn ə spræi dzan

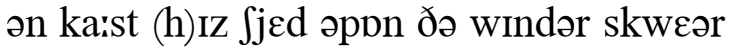
vər bə:rdz də no: ðər fren(d)z ən bild ðər nest ən $\mathrm{l} \Lambda \mathrm{v}$ tə ru:st (h)wər ठe: kən liv ət rest

ə:ut ə tə:un ðə win(d) də brin dzan pi:lz ə belz (h)wen ðe: də rin dzan ən rə'un mi: hiər ət han(d) mə:I iər kən kat ðə mæId əzIngən b(ə:)I ðə stri:m dzan ar ka:rtər (h)wislən wi (h)Iz ti:m dzan ar zingən bə:rdz ar wo:tər ət ðə hat ən zu: wi sərun(d)z ə væIs ən bə:rd ən bel nu: ə:uər Iz $\mathrm{d} \Lambda 1$ IðIn ə:uər ruəzi $d \varepsilon l$

ən (h)wعn ðə da:rksəm nə:It də hə:Id dzan lan(d) ən wud pn evri zə:Id dzan ən (h)wعn ठə lə:Its əbə:rnən pn mə:I buərd ðદn vər plezərz ə:ut ə duər dzan ə:IV in $\Lambda$ ə əppn mə:I vluər dzan

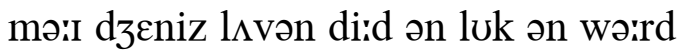

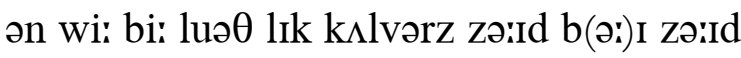
tə liəv ðə plæin əbo:d (h)wər $1 \Lambda \mathrm{v}$ də bə:Id 


\section{HALLOWED PLEÄCES}

AT Woodcombe farm, wi' ground an' tree

Hallow'd by times o' youthvul glee,

At Chris'mas time I spent a night

Wi' feäces dearest to my zight;

An' took my wife to tread, woonce mwore, once

Her maïden hwome's vorseäken vloor,

An' under stars that slowly wheel'd

Aloft, above the keen-air'd vield,

While night bedimm'd the rus'lèn copse,

An' darken'd all the ridges' tops,

The hall, a-hung wi' holly, rung

Wi' many a tongue o' wold an' young.

There, on the he'th's well-hetted ground,

Hallow'd by times o' zittèn round,

The brimvul mug o' cider stood

An' hiss'd avore the bleäzèn wood;

An' zome, a-zittèn knee by knee,

Did tell their teäles wi' hearty glee,

An' others gamboll'd in a roar

O' laughter on the stwonèn vloor;

stone

An' while the moss o' winter-tide

Clung chilly roun' the house's zide,

The hall, a-hung wi' holly, rung

Wi' many a tongue o' wold an' young.

There, on the pworches bench o' stwone,

Hallow'd by times o' youthvul fun,

We laugh'd an' sigh'd to think o' neämes

That rung there woonce, in evenèn geämes; 
halərd pljesız

ət wudku:m fa:rm wi grə:un(d) ən tri:

halərd b(ə:)I tə:Imz ə ju:Өvul gli:

ət krisməs tə:Im əiI spent ə nə:it

wi fjesız diərist to mə:I zə:It

ən tuk mə:I wə:If to tred (w)uins muər

(h)ər mæidən huəmz varsjekən vluər

ən $\Lambda$ ndər sta:rz ðət slo:li (h)wild

əlpft əbムv ðə ki:næIrd vi:ld

(h)wə:Il nə:It bidımd ðə r $\Lambda$ slən kpps

ən da:rkənd a:l ठə r $\Lambda$ dz $z$ z tops

ðə ha:l əh^y wi holi rıy

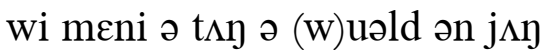

ðər pn ðə heӨs welhetıd grə:un(d)

halərd b(ə:)I tə:Imz ə zitən rə:un(d)

ðə brimvul m^g ə sə:Idər stud

ən hist əvuər ðə bljezən wud

ən z^m əzitən ni: b(əi)I ni:

did tel ðər tjelz wi ha:rti gli:

ən $\Lambda$ ðərz gambəld in ə ruər

ə le:ftər pn ðə stuənən vluər

ən (h)wə:Il ðə mps ə wintərtə:Id

klıy t fili rə:un ðə hə:usız zə:Id

ðə ha:l əh^y wi holi rıy

wi meni ə tムy ə (w)uəld ən $\mathrm{j} \Lambda \mathrm{y}$

ðər pn ðə puərt $\int \mathrm{Iz}$ bent $\int$ ə stuən

halərd b(ə:)I tə:Imz ə ju:Өvul f $\wedge$ n

wi: le:ft ən sə:Id to ठınk ə njemz

ðət $\mathrm{r} \Lambda \mathrm{y}$ ठər (w)u:ns in iivmən gjemz 
An' while the swaÿèn cypress bow'd,

In chilly wind, his darksome sh'oud

An' honeyzuckles, beäre o' leaves,

canopy

bare

Still reach'd the window-sheädèn eaves

Up where the clematis did trim

The stwonèn arches mossy rim,

The hall, a-hung wi' holly, rung

Wi' many a tongue o' wold an' young.

There, in the geärden's wall-bound square,

Hallow'd by times o' strollèn there,

The winter wind, a-hufflèn loud,

gusting

Did swaÿ the pear-tree's leafless sh'oud,

An' beät the bush that woonce did bear

canopy

once

The damask rwose vor Jenny's heäir;

An' there the walk o' peävèn stwone

That burn'd below the zummer zun,

Struck icy-cwold drough shoes a-wore

By maïdens vrom the hetted vloor

through

In hall, a-hung wi' holm, where rung

beated

Vull many a tongue o' wold an' young.

bolly

There at the geäte that woonce wer blue

Hallow'd by times o' passèn drough,

Light strawmotes rose in flaggèn flight,

straw-stalks

A-floated by the winds o' night,

Where leafy ivy-stems did crawl

In moonlight on the windblown wall,

An' merry maïdens' vaïces vled

In echoes sh'ill, vrom wall to shed,

As shiv'rèn in their frocks o' white

They come to bid us there "Good night,"

Vrom hall, a-hung wi' holm, that rung

Wi' many a tongue o' wold an' young. 
ən (h)wə:ıl ðə swæıən sə:ıprəs bə:ud

In t fIli win(d) (h)Iz da:rksəm Sərud

ən h^nizıkəlz bjeər ə liivz

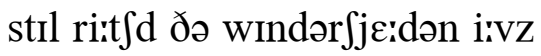

$\Lambda \mathrm{p}$ (h)wər ðə klemətıs did trim

ðə stuənən a:rt $\int \mathrm{Iz}$ mpsi rım

ðə ha:l əhıy wi holi rıy

wi meni ə tıy ə (w)uəld ən j $\wedge$ y

ðər In ðə gja:rdənz wa:lbə:un(d) skwعər

halərd b(ə:)I tə:Imz ə stro:lən ðعər

ðə wintər win(d) əhıflən lə:ud

dıd swæi ðə peərtrizz li:flıs Sə:ud

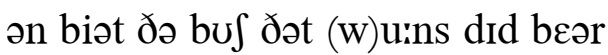

ðə daməsk ruəz vər dzeniz hjєər

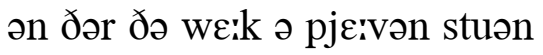

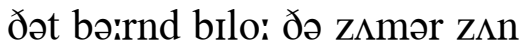

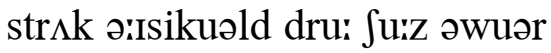

b(ə:)I mæIdənz vrəm ðə hetıd vluər

In ha:l əh $\Lambda$ y wi ho:m (h)wər r $\wedge$ y

vul meni ə t $\wedge$ y ə (w)uəld ən j $\Lambda$ y

ðər ət ðə gjet ðət (w)u:ns wər blu:

halərd b(ə:)I tə:Imz ə paisən dru:

lə:It stre:mo:ts ro:z in flagən flə:it

əflo:tıd b(ə:)I ठə win(d)z ə nə:It

(h)wər li:fi ə:Ivistemz did kra:l

In mu:nlə:it pn ðə win(d)blo:n wa:l

ən meri mæidənz væIsIz vled

In eko:z $\int \mathrm{ll}$ vrəm wa:l to $\int \varepsilon d$

az $\int$ Ivrən in ðər froks ə (h)wə:It

ðе: kım tə bid əs ðər gud nə:It

vrəm ha:l əhıy wi ho:m ðət $\mathrm{r} \wedge$ y

wi meni ə t $\Lambda$ y ə (w)uəld ən j $\wedge$ y 
There in the narrow leäne an' drong lane, path between hedges Hallow'd by times o' gwaïn along, going The lofty ashes' leafless sh'ouds tops

Rose dark avore the clear-edged clouds, The while the moon, at girtest height, greatest Bespread the pooly brook wi' light, An' as our child, in loose-limb'd rest, Lay peäle upon her mother's breast, Her waxen eyelids seal'd her eyes

Vrom darksome trees, an' sheenèn skies, shining An' halls a-hung wi' holm, that rung Wi' many a tongue, o' wold an' young. 
ðər In ðə narə(r) ljen ən droy

halərd b(ə:)I tə:Imz ə gwæIn əlpy

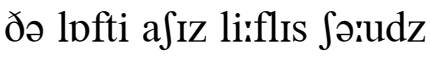

ro:z da:rk əvuər ðə kliəredzd klə:udz

ðə (h)wə:Il ðə mu:n ət gə:rtist hə:It

bispred ðə puili bruk wi lə:It

ən az əruər tfə:Il(d) In luislimd rest

le: pjel əppn (h)ər m^ðərz brest

(h)ər waksən ərilidz si:ld (h)ər ə:Iz

vrəm da:rksəm tri:z on Siinən skə:Iz

ən ha:lz əh^y wi ho:m ðət rıy

wi meni ə t $\Lambda$ y ə (w)uəld ən j $\Lambda$ y 
HERE, Jeäne, we vu'st did meet below first

The leafy boughs, a-swingèn slow, Avore the zun, wi' evenèn glow,

Above our road, a-beamèn red;

The grass in zwath wer in the meäds, The water gleäm'd among the reeds

In aïr a-steälen roun' the hall, Where ivy clung upon the wall. Ah! well-a-day! O wall adieu!

The wall is wold, my grief is new.

An' there you walk'd wi' blushèn pride,

Where softly-wheelèn streams did glide,

Drough sheädes o' poplars at my zide, through shadows

An' there wi' love that still do live,

Your feäce did wear the smile o' youth,

The while you spoke wi' age's truth,

An' wi' a rwosebud's mossy ball,

I deck'd your bosom vrom the wall.

Ah! well-a-day! O wall adieu!

The wall is wold, my grief is new.

But now when winter's raï do vall,

An' wind do beät ageän the hall,

The while upon the wat'ry wall

In spots o' grey the moss do grow;

The ruf noo mwore shall overspread

The pillor ov our weary head,

Nor shall the rwose's mossy ball

Behang vor you the house's wall.

Ah! well-a-day! O wall adieu!

The wall is wold, my grief is new. 
ðə (w)uəld wa:l

hiər d3jen wi: vast did mi(:)t bilo:

ðə li:fi bə:uz əswinən slo:

əvuər ðə z^n wi i:vmən glo:

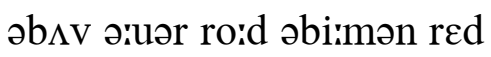

ðə gra:s in zwp $\theta$ wər in ðə miədz

ðə wə:tər gliəmd əmpy ðə ri:dz

In æIr əstiələn rə:un ðə ha:l

(h)wər ə:Ivi klıy əppn ðə wa:l

a: weləde: o: wa:l adju:

ðə wa:l Iz (w)uəld mə:I gri:f Iz nju:

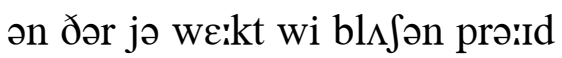

(h)wər spf(t)li(h)wi:lən stri:mz did glə:Id

dru: $\int j \varepsilon d z$ ə ppplərz ət mə:I zə:Id

ən ठər wi $1 \Lambda \mathrm{v}$ ðət strl də liv

jər fjes did weər ðə smə:ıl ə jui $\theta$

ðə (h)wə:ıl jə spo:k wi ع:dżIz tru: $\theta$

ən wi ə ruəzb $\Lambda \mathrm{dz}$ mpsi ba:l

ə:I dekt jər b $\Lambda$ zəm vrəm ðə wa:l

a: weləde: o: wa:l adju:

ðə wa:l Iz (w)uəld mə:I gri:f Iz nju:

bət nə:u (h)wen wintərz ræIn də va:l

ən $\operatorname{win}(\mathrm{d})$ də biət əgjen ठə ha:l

ðə (h)wə:Il əppn ðə wə:tri wa:l

In sppts ə gre: ðə mps də gro:

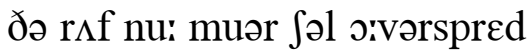

ðə pilər əv ə:uər wiəri hed

nar $\int ə l$ ðə ruəzız mpsi ba:l

bihaך vər ju: ðə hə:usız wa:l

a: weləde: o: wa:l adju:

ðə wa:l Iz (w)uəld mə:I gri:f Iz nju: 
JOHN BLEÄKE he had a bit o' ground

Come to en by his mother's zide; bim An' after that, two hunderd pound

His uncle left en when he died;

"Well now," cried John, "my mind's a-bent

To build a house, an' paÿ noo rent."

An' Meäry gi'ed en her consent.

"Do, do,"- the maïdens cried.

“True, true,"- - his wife replied.

"Done, done,-a house o' brick or stwone,"

Cried merry Bleäke o’ Blackmwore.

Then John he call'd vor men o' skill,

An' builders answer'd to his call;

An' met to reckon, each his bill;

Vor vloor an' window, ruf an' wall.

An' woone did mark it on the groun',

An' woone did think, an' scratch his crown,

An' reckon work, an' write it down:

“Zoo, zoo,"-woone treädesman cried,

“True, true,"-woone mwore replied.

"Aye, aye,-_good work, an' have good pä̈,"

Cried merry Bleäke o’ Blackmwore.

The work begun, an' trowels rung, An' up the brickèn wall did rise, An' up the slantèn refters sprung, Wi' busy blows, an' lusty cries! An' woone brought planks to meäke a vloor, An' woone did come wi' durns or door, An' woone did zaw, an' woone did bore. 
blje:ks hərus in blakmuər

dzan blje:k ə had ə bit ə grə:un(d) kım tu: ən b(ə:)I (h)Iz m $\Lambda$ ðərz zə:Id

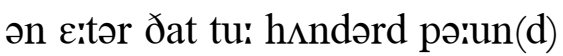
(h)Iz $\Lambda$ jkəl left ən (h)wen ə də:Id wel nə:u krə:Id dzan mə:I mə:In(d)z əbent to bild ə hə'us ən pæi nu: rent ən mjeəri gi:d ən (h)ər kənsent du: du: ðə mæIdənz krə:Id tru: tru: (h)Iz wə:If riplə:Id $\mathrm{d} \Lambda \mathrm{n} \mathrm{d} \Lambda \mathrm{n}$ ə hərus ə brik ər stuən krə:Id meri blje:k ə blakmuər

ðعn dzan ə ka:ld vər men ə skıl ən bildərz ع:nsərd tu (h)rz ka:l ən met to rekən i:t (h)Iz bil vər vluər ən windər $\mathrm{r} \Lambda \mathrm{f}$ ən wa:l ən (w)u:n did ma:rk it pn ðə grə:un ən (w)u:n did ðınk ən skrat (h)Iz krə:un ən rekən wə:rk ən rə:It it də:un zu: zu: (w)uin trje:dzmən krə:Id tru: tru: (w)u:n muər ripləisd æI æI gud wərrk ən hav gud pæI krə:Id meri blje:k ə blakmuər

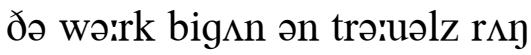
ən $\Lambda$ р ðə brikən wa:l did rə:Iz әn $\Lambda$ р бə sle:ntən re:ftərz spr $\wedge$ y wi bızi blo:z ən lısti krə:Iz ən (w)u:n bro:t playks tə mjek ə vluər ən (w)uin did kım wi də:rnz ər duər ən (w)u:n did ze: ən (w)u:n did buər 
"Brick, brick,-—there down below,

Quick, quick,-why b'ye so slow?"

"Lime, lime,- - why we do weäste the time,

Vor merry Bleäke o’ Blackmwore.”

The house wer up vrom groun' to tun,

chimney-top

An' thatch'd ageän the raïny sky,

Wi' windows to the noonday zun,

Where rushy Stour do wander by.

In coo'se he had a pworch to screen

of course

The inside door, when win's wer keen,

An' out avore the pworch, a green.

"Here! here!"- - the childern cried:

"Dear! dear!"- - the wife replied;

"There, there,- - the house is perty feäir,"

Cried merry Bleäke o’ Blackmwore.

Then John he ax'd his friends to warm

asked

His house, an' they, a goodish batch,

Did come alwone, or eärm in eärm,

arm in arm

All roads, a-meäkèn vor his hatch:

wicket-gate

An' there below the clavy beam

mantlepiece

The kettle-spout did zing an' steam;

An' there wer ceäkes, an' tea wi' cream.

"Lo! lo!"- the women cried;

"Ho! ho!"- - the men replied;

"Health, health,- -attend ye wi' your wealth,

Good merry Bleäke o’ Blackmwore.”

Then John, a-prais'd, flung up his crown, All back a-laughèn in a roar.

They praïs'd his wife, an' she look'd down

A-simperèn towards the vloor. 
brik brik ðər də:un bilo:

kwık kwık (h)wə:I bji: sə slo:

lə:Im lə:Im (h)wə:I wi: də wjest ðə tə:Im

vər meri blje:k ə blakmuər

ðə hə:us wər $\Lambda \mathrm{p}$ vrəm grə:un to t $\Lambda$ n

ən ðat $\int t$ əgjen ðə ræIni skə:I

wi windərz tə ðə nu:nde: z^n

(h)wər $\mathrm{r} \Lambda$ Si stə:uər də wondər bə:I

In kuis ə had ə puort 5 to skri:n

ði Insə:Id duər (h)wen win(d)z wər ki:n

ən əiut əvuər ठə puərt $\int$ ə gri:n

hiər hiər ðə t $\mathrm{t}$ Ildərn krə:Id

diər diər ðə wə:If riplə:Id

ðعər ðعər ðə hə'us IZ pərrti fjeər

krə:Id meri blje:k ə blakmuər

ðعn dzan hi: a:kst (h)Iz fren(d)z tə wa:rm

(h)Iz hə:us ən ðe: ə gudis bat

did kım əluən ar ja:rm in ja:rm

a:l ro:dz əmjekən vər (h)Iz hat

ən ðər bılo: ðə klavi bi:m

ðə ketəlspə:ut did zin ən sti:m

ən ðər wər kje:ks ən te: wi kri:m

lo: lo: ðə wumin krə:Id

ho: ho: ðə men riplə:Id

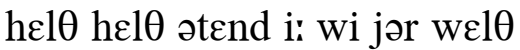

gud meri blje:k a blakmuər

ðعn dzan əpræızd flıy $\Lambda p$ (h)Iz krə:un

a:l bak əle:fən in ə ruər

ðe: præIzd (h)IZ wə:If ən Ji: lukt də:un

əsimpərən təwa:rdz ðə vluər 
Then up they sprung a-dancèn reels, An' up went tooes, an' up went heels, toes A-windèn roun' in knots an' wheels.

"Brisk, brisk,"- - the maïdens cried;

"Frisk, frisk,"- the men replied;

"Quick, quick,-—there wi' your fiddle-stick,"

Cried merry Bleäke o’ Blackmwore.

An' when the morrow's zun did sheen, shine

John Bleäke beheld, wi' jaÿ an' pride,

His brickèn house, an' pworch, an' green, Above the Stour's rushy zide.

The zwallows left the lwonesome groves, To build below the thatchèn oves, eaves An' robins come vor crumbs o' lwoaves:

"Tweet, tweet,"- - the birds all cried; "Sweet, sweet,"-John's wife replied;

"Dad, dad,"- the childern cried so glad, To merry Bleäke o’ Blackmwore. 


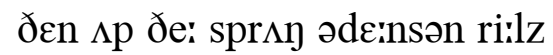
ən $\Lambda p$ went tu:z ən $\Lambda p$ went hi:lz əwə:In(d)ən rə:un In npts ən (h)willz brisk brisk ðə mæidənz krə:Id frisk frisk ðə men riplə:Id kwık kwık ðər wi jər fıdəlstık krə:Id meri blje:k ə blakmuər

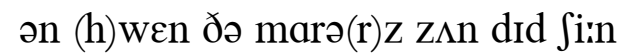
dzan blje:k biheld wi dzæı ən prə:Id (h)Iz brikən hə:us ən puərt $\int$ ən gri:n

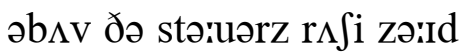
ðə zwplərz left ðə luənsəm gro:vz to bild bilo: ðə ðatfən o:vZ ən robinz kım vər krımz ə luəvz twi(:)t twi(:)t ðə bə:rdz a:l krə:Id swi(:)t swi(:)t dzanz wə:If riplə:Id dad dad ðə t fildərn krə:Id sə glad to meri blje:k a blakmuər 
No: where the woak do overspread, oak

The grass begloom'd below his head, An' water, under bowèn zedge, bending

A-springèn vrom the river's edge,

Do ripple, as the win' do blow,

An' sparkle, as the sky do glow;

An' grey-leav'd withy-boughs do cool,

willow-

Wi' darksome sheädes, the clear-feäced pool,

shadows

My chimny smoke, 'ithin the lew

shelter

$\mathrm{O}$ ' trees is there arisèn blue;

Avore the night do dim our zight,

Or candle-light, a-sheenèn bright,

Do sparkle drough the window.

shining

through

When crumpled leaves o' Fall do bound

Avore the wind, along the ground,

An' wither'd bennet-stems do stand

grass-stalks

A-quiv'rèn on the chilly land;

The while the zun, wi' zettèn rim,

Do leäve the workman's pathway dim;

An' sweet-breath'd childern's hangèn heads

Be laid wi' kisses, on their beds;

Then I do seek my woodland nest,

An' zit bezide my vier at rest, fire

While night's a-spread, where day's a-vled, flown by An' lights do shed their beams o' red,

A-sparklèn drough the window.

If winter's whistlèn winds do vreeze

The snow a-gather'd on the trees,

An' sheädes o' poplar stems do vall

shadows, trunks

In moonlight up athirt the wall;

across 
dzan blje:k ət huəm ət nə:It

no: (h)wər ðə (w)uək du ə:vərspred

ðə gra:s biglu:md bilo: (h)Iz hed

ən wo:tər $\Lambda$ ndər bə:uən $\mathrm{z}^{\mathrm{d}} \mathrm{d}_{3}$

әsprinən vrəm ðə rivərz $\varepsilon d_{3}$

də ripəl əz ðə wIn(d) də blo:

ən spa:rkəl əz ðə skə:I də glo:

ən gre:li:vd wıðibəruz də ku:l

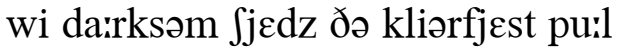

mə:I t Imli smo:k ıðın ðə lu:

ə tri:z Iz ðər ərə:Izən blu:

əvuər ðə nə:It də dim ə:uər zə:It

ar kandəl lə:it ə)i:nən brə:It

də spa:rkəl dru: ðə windər

(h)wen kr^mpəld liivz ə fa:l də bərun(d)

әvuər ðə win(d) əlpy ðə grə:un(d)

ən wiðərd benitstemz də $\operatorname{stan}(\mathrm{d})$

əkwıvrən pn ðə t $\int \mathrm{lli} \operatorname{lan}(\mathrm{d})$

ðə (h)wə:Il ठə z^n wi zetən rım

də liəv ðə wə:rkmənz pe:Өwə:I dim

ən swi(:)tbre $\theta \mathrm{t} t \mathrm{t}$ Ild

bi: led wi kisız pn ðər bedz

ðعn ə:I də si:k mə:I (w)Udlən(d) nest

ən zit bizə:Id mə:I və:Iər ət rest

(h)wə:Il nə:Its əspred (h)wər de:z əvled

ən lə:its də $\int \varepsilon d$ ðər bi:mz ə red

әspa:rklən dru: ðə windər

If wintərz (h)wislən win(d)z də vri:z

ðə sno: əgaðərd pn ðə tri:z

ən $\int j \varepsilon d z$ ə ppplər stemz də va:l

In mu:nlə:it $\Lambda$ р əðə:rt ðə wa:l 
An' icicles do hang below

The oves, a-glitt'rèn in a row,

eaves

An' risèn stars do slowly ride

Above the ruf's upslantèn zide;

roof's

Then I do lay my weary head

Asleep upon my peaceful bed,

When middle-night ha' quench'd the light

Ov embers bright, an' candles white

A-beamèn drough the window. 
ən ə:Isıkəlz də hay bilo:

ði o:vz əglitrən In ə ro:

ən rə:Izən sta:rz də slo:li rə:Id

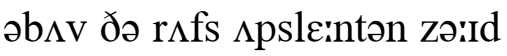

ðعn ə:I də le: mə:I wiəri hed

əsli:p əppn mə:I pissful bed

(h)wen midəl nə:It hə kwentft ðə lə:It

əv عmbərz brə:It ən kandəlz (h)wə:It

əbi:mən dru: ðə windər 


\section{MILKÈN TIME}

'TWER when the busy birds did vlee,

Wi' sheenèn wings, vrom tree to tree, fly

To build upon the mossy lim'

Their hollow nestes' rounded rim;

The while the zun, a-zinkèn low,

Did roll along his evenèn bow, $\operatorname{arc}$

I come along where wide-horn'd cows,

'Ithin a nook, a-screen'd by boughs,

Did stan' an' flip the white-hoop'd pails

Wi' heäiry tufts o' swingèn tails;

An' there wer Jenny Coom a-gone

Along the path a vew steps on,

A-beärèn on her head, upstraïght,

Her pail, wi' slowly-ridèn waïght,

An' hoops a-sheenèn, lily-white,

Ageän the evenèn's slantèn light;

An' zo I took her pail, an' left

Her neck a-freed vrom all his heft;

An' she a-lookèn up an' down,

Wi' sheäpely head an' glossy crown,

Then took my zide, an' kept my peäce

its weight

A-talkèn on wi' smilèn feäce,

An' zettèn things in sich a light,

I'd faïn ha' heär'd her talk all night;

An' when I brought her milk avore

The geäte, she took it in to door,

An' if her pail had but allow'd

Her head to vall, she would ha' bow'd,

An' still, as 'twer, I had the zight

Ov her sweet smile droughout the night. 
milkən tə:Im

twər (h)wen ðə bızi bə:rdz did vli:

wi Jiinən winz vrəm tri: to tri:

to bild əppn ðə mpsi lim

ðər hplər nestız rə:undid rim

ðə (h)wə:Il ðə z^n əzıjkən lo:

did ro:l əlpy (h)Iz i:vmən bo:

ə:I kım əlpy (h)wər wə:Idha:rnd kə:uz

IðIn ə nuk əskriind $b($ (ə) I bə:uz

dıd stan ən flıp ðə (h)wə:Ithu:pt pæilz

wi hjeəri t $\Lambda$ fts ə swinən tæilz

ən ठər wər dzeni ku:m əgpn

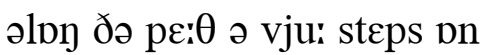

əbeərən pn (h)ər hed $\Lambda$ pstræit

(h)ər pæil wi slo:lirə:Idən wæit

ən hu:ps əfi:nən lili (h)wə:It

əgjen ði i:vmənz sle:ntən lə:it

ən zu: ə:I tuk (h)ər pæil ən left

(h)ər nek əfri:d vrəm a:l (h)Iz heft

ən $\int \mathrm{i}$ : əlukən $\Lambda \mathrm{p}$ ən də‘un

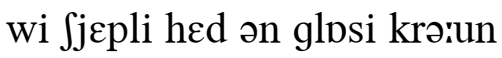

ðعn tuk mə:I zə:Id ən kept mə:I pjes

əte:kən pn wi smə:ilən fjes

ən zetən ðinz in sit $\int$ ə lə:It

ə:Id fæin hə hiərd (h)ər te:k a:l nə:It

ən (h)wen əiI bro:t (h)ər milk əvuər

ðə gjet $\int i$ i: tuk It in to duər

ən If (h)ər pæil had bət ələ:ud

(h)ər hed to va:l fir wud hə bə:ud

ən strl az twər ə:I had ðə zə:It

əv (h)ər swi(:)t smə:Il drurə:ut ðə nə:It 
WHEN BIRDS BE STILL

VOR all the zun do leäve the sky, An' all the sounds o' day do die,

An' noo mwore veet do walk the dim

Vield-path to clim' the stiel's bars, stile's

Yeet out below the rizèn stars,

The dark'nèn day mid leäve behind yet

Woone tongue that I shall always vind, may

A-whisperèn kind, when birds be still.

Zoo let the day come on to spread so

His kindly light above my head,

Wi' zights to zee, an' sounds to hear,

That still do cheer my thoughtvul mind;

Or let en goo, an' leäve behind it

An' hour to stroll along the gleädes,

Where night do drown the beeches' sheädes, shadows

On grasses' bleädes, when birds be still.

Vor when the night do lull the sound

O' cows a-bleärèn out in ground,

The sh'ill-vaïc'd dog do stan' an' bark

bellowing, field

'Ithin the dark, bezide the road;

An' when noo cracklèn waggon's lwoad

Is in the leäne, the wind do bring

The merry peals that bells do ring

O ding-dong-ding, when birds be still.

Zoo teäke, vor me, the town a-drown'd

'Ithin a storm o' rumblèn sound,

An' gi'e me vaïces that do speak

give

So soft an' meek, to souls alwone; 
(h)wen bə:rdz bi: stıl

vər a:l ðə z^n də liəv ðə skə:I

ən a:l ठə sə:un(d)z ə de: də də:I

ən nu: muər vi:t də we:k ठə dim

vi:l(d)pe: $\theta$ tə klim ðə stə:ıəlz ba:rz

(j)iit ə:ut bilo: ðə rə:Izən sta:rz

ðə da:rknən de: mid liəv bihə:In(d)

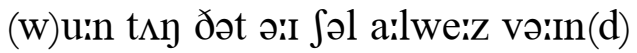

ə(h)wispərən kə:In(d) (h)wen bə:rdz bi: strl

zu: let ðə de: kım pn tə spred

(h)Iz kə:In(d)li lə:It əb $\Lambda \mathrm{v}$ mə:I hed

wi zə:Its to zi: ən $\operatorname{sə}: u n(d) z$ to hiər

ðət stıl də tfiər mə:I $\theta$ o:tvul mə:In(d)

ar let ən gu: ən liəv bihə:in(d)

ən ə'uər tə stro:l əlpy ðə gljedz

(h)wər nə:It də drə:un ðə bi:t $\int \mathrm{Iz} \int j \varepsilon d z$

pn gra:sız bljedz (h)wen bə:rdz bi: stıl

vər (h)wعn ðə nə:It də $1 \Lambda 1$ ðə sə:un(d)

ə kə'uz əbljeərən ə:ut In grə:un(d)

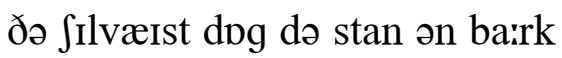

ıðın ðə da:rk bızə:Id ðə ro:d

ən (h)wen nu: kraklən wagənz luəd

IZ In ठə ljen ठə win(d) də brin

ðə meri pi:lz ðət belz də rı̄

o: dindpydin (h)wen bə:rdz bi: strl

zu: tjek vər mi: ðə tə:un ədrə:und

IðIn ə sta:rm ə r $\Lambda$ mblən sə:un(d)

ən gi: mi: væIsız ðət də spi:k

sə spft ən mi:k tə so:lz əluən 
The brook a-gurglèn round a stwone, An' birds o' day a-zingèn clear, An' leaves, that I mid zit an' hear may

A-rustlèn near, when birds be still. 
ðə bruk əgə:rglən rə:un(d) ə stuən ən bərrdz ə de: əzingən kliər ən liivz ठət ə:I mId zit ən hiər ər $\Lambda$ slən niər (h)wen bə:rdz bi: stıl 
OH! no, I quite injaÿ'd the ride enjoyed

Behind wold Dobbin's heavy heels, old

Wi' Jeäne a-prattlèn at my zide,

Above our peäir o' spinnèn wheels,

As grey-rin'd ashes' swaÿèn tops -barked

Did creak in moonlight in the copse,

Above the quiv'rèn grass, a-beät

By wind a-blowèn drough the geät.

If weary souls did want their sleep,

They had a-zent vor sleep the night;

Vor vo'k that had a call to keep folk

Awake, lik' us, there still wer light.

An' He that shut the sleepers' eyes,

A-waïtèn vor the zun to rise,

$\mathrm{Ha}$ ' too much love to let em know

The ling'rèn night did goo so slow.

But if my wife did catch a zight

O' zome queer pollard, ${ }^{3}$ or a post,

Poor soul! she took en in her fright

To be a robber or a ghost.

A two-stump'd withy, wi' a head,

willow

Mus' be a man wi' eärms a-spread;

arms

An' foam o' water, round a rock,

Wer then a drownèn leädy's frock.

Zome staddle stwones to bear a mow,

stones for the base of a baystack

Wer dancèn veäries on the lag;

fairies

An' then a snow-white sheeted cow

Could only be, she thought, their flag,

${ }^{3}$ Pollard: a tree with its top and upper branches cut back. 
rə:Idən huəm ət nə:It

o: no: ə:I kwə:It Indzæid ðə rə:Id

bihə:In(d) (w)uəld dobinz hevi hi:lz

wi dzjen əpratlən ət mə:I zə:Id

əb $\Lambda$ v ə:uər pjeər ə spinən (h)wi:lz

əz gre:rə:Ind a a Iz swæiən tops

did kri:k in mu:nlə:It In ðə kpps

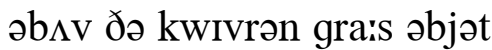

b(ə:)I WIn(d) əblo:ən dru: ðə gjət

If wiəri so:lz did wont ðər sli:p

ðе: had əzent vər sli:p ðə nə:It

vər vo:k dət had ə ka:l to ki(:)p

әwjek lik $\Lambda$ s ðər stıl wər lə:it

ən hi: ठət $\int \Lambda \mathrm{t}$ ठə sli:pərz ə:Iz

əwæitən vər ðə Zın tə rə:IZ

ha tu: $\mathrm{m} \Lambda \mathrm{t} \int \mathrm{l} \Lambda \mathrm{v}$ to let $\partial \mathrm{m}$ no:

ðə lingrən nə:It did gu: sə slo:

bət If mə:I wə:If did kat $\int$ z zə:It

ə zım kwi:r ppla:rd ar a poist

pu(:)ər so:l ji: tuk ən in (h)ər frə:It

to bi: a robər ər a go:st

ə tuist $\Lambda$ mpt wıði wi a hed

m $\Lambda$ s bi: ə man wi jarrmz əspred

ən fo:m ə wo:tər rə:un(d) ə rok

wər ðદn ə drə:unən ljediz frok

zəm stadəl stuənz tə beər ə mo:

wər de:nsən vjeəriz pn ðə lag

ən ठعn ə sno:(h)wə:It fi:tıd kə:u

kud o:nli bi: Si: ðo:t ðər flag 
An owl a-vleèn drough the wood

Wer men on watch vor little good;

An' geätes a slam'd by wind, did goo,

She thought, to let a robber drough.

But after all, she lik'd the zight

O' cows asleep in glitt'rèn dew;

An' brooks that gleam'd below the light,

An' dim vield paths 'ithout a shoe.

An' gaily talk'd bezide my ears,

A-laughèn off her needless fears:

Or had the childern uppermost

In mind, instead o' thief or ghost.

An' when our house, wi' open door,

Did rumble hollow round our heads, She heästen'd up to tother vloor,

To zee the childern in their beds;

An' vound woone little head awry,

Wi' woone a-turn'd toward the sky;

An' wrung her hands ageän her breast,

A-smilèn at their happy rest. 
ən ə:ul əvli:ən dru: ðə wud

wər men pn wpt $\int$ vər litəl gud

ən gjets ə slamd $b(\partial i) I$ WIn(d) did gu:

Si: ðo:t to let a robər dru:

bət ع:tər a:1 Ji: likt ðə zə:It

ə kə:uz əsli:p in glitrən dju:

ən bruks ðət gli:md bılo: ðə lə:ıt

ən dim vi:l(d) pe:ðz Iðə:ut ə $\int u:$

ən gæili te:kt bızə:Id mə:I iərz

əlદ:fən pf (h)or ni:dlis fiərz

ar had ðə t $\int$ Ildərn $\Lambda$ pərmo:st

In mə:In(d) Insted ə ði:f ər go:st

ən (h)wen ə:uər hə:us wi o:bən duər

did rımbəl hplər rə:un(d) ə:uər hedz

Si: hjesənd $\Lambda p$ to t $\Lambda$ ðər vluər

tə zi: ðə tfildərn in ðər bedz

ən və:un(d) (w)u:n litəl hed ərə:I

wi (w)u:n ətə:rnd təwa:rd ðə skə:I

ən ruy (h)ər han(d)z əgjen (h)ər brest

əsmə:Ilən ət ðər hapi rest 
WHERE the western zun, unclouded,

Up above the grey hill-tops,

Did sheen drough ashes, lofty sh'ouded,

On the turf bezide the copse,

In zummer weather,

We together,

Sorrow-slightèn, work-vorgettèn,

Gambol'd wi' the zun a-zettèn.

There, by flow'ry bows o' bramble,

Under hedge, in ash-tree sheädes, shine through, bigh-topped The dun-heair'd ho'se did slowly ramble curved stems shadows horse

On the grasses' dewy bleädes, Zet free o' lwoads, An' stwony rwoads, Vorgetvul o' the lashes frettèn, stinging Grazèn wi' the zun a-zettèn.

There wer rooks a-beätèn by us

Drough the air, in a vlock, An' there the lively blackbird, nigh us, through

On the meäple bough did rock,

Wi' ringèn droat, throat

Where zunlight smote

The yollow boughs o' zunny hedges

Over western hills' blue edges.

Waters, drough the meäds a-purlèn,

Glissen'd in the evenèn's light, An' smoke, above the town a-curlèn,

Melted slowly out o' zight; 
(h)wər ðə westərn z^n $\Lambda$ nklə:udid

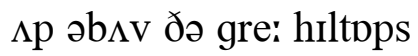

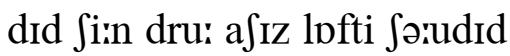
pn ðə tə:rf bizə:Id ðə kpps In zımər weðər wi: təgeðər sarə(r)sləittən wərrkvərgetən gambəld wi ðə zın əzctən

ðər b(ə:)I flə:uri bo:z ə brambəl $\Lambda$ ndər hedz In astri: $\int j \varepsilon d z$ ðə d $\Lambda$ nhjeərd hos did slo:li rambəl pn ðə gra:sız djuii bljedz zet fri: ə luədz ən stuəni ruədz vərgetvul ə ðə la laz fretən grjezən wi ðə z^n əzદtən

ðər wər ruks əbiətən bə:I əs dru: ði æiər in ə vlpk ən ðər ðə lə:Ivli blakbə:rd nə:I əs pn ðə mjepəl bə:u did rok wi rinən dro:t (h)wər z^nlə:It smo:t ðə jalər bə:uz ə z^ni hedzIZ o:vər westərn hilz blu: $\varepsilon d z I Z$

wə:tərz dru: ðə miədz əpə:r(d)lən glisənd In ði i:vmənz lə:it ən smo:k əb $\Lambda \mathrm{v}$ ðə tə:un əkə:r(d)lən meltıd slo:li ə:ut ə zə:It 
An' there, in glooms

Ov unzunn'd rooms,

To zome, wi' idle sorrows frettèn,

Zuns did set avore their zettèn.

We were out in geämes and reäces,

Loud a-laughèn, wild in me'th,

mirth

Wi' windblown heäir, an' zunbrown'd feäces,

Leäpen on the high-sky'd e'th,

earth

Avore the lights

Wer tin'd o' nights,

lost

An' while the gossamer's light nettèn

Sparkled to the zun a-zettèn. 
ən ðər in glu:mz

əv $\Lambda$ nzınd ruimz

to $\mathrm{z} \Lambda \mathrm{m}$ wi ə:Idəl sarə(r)z fretən

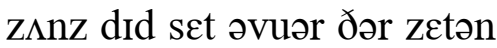

wi: wər ə:ut in gjemz ən(d) rjesız

lə:ud əle:fən wəril(d) in me $\theta$

wi win(d)blo:n hjeər ən zınbrə:und fjesız

liəpən pn ðə hə:Iskə:Id $\varepsilon \theta$

әvuər ðə lə:Its

wər tə:Ind a nə:Its

ən (h)wə:Il ðə gpsəmərz lə:It netən

spa:rkəld tə ðə z^n əzctən 


\section{SPRING}

Now the zunny airr's a-blowèn

Softly over flowers a-growèn;

An' the sparklèn light do quiver

On the ivy-bough an' river;

Bleätèn lambs, wi' woolly feäces,

Now do plaÿ, a-runnèn reäces;

$$
\begin{aligned}
& \text { An' the springèn } \\
& \text { Lark's a-zingèn, }
\end{aligned}
$$

Lik' a dot avore the cloud,

High above the ashes' sh'oud.

canopy

Housèn, in the open brightness,

Now do sheen in spots o' whiteness;

shine

Here an' there, on upland ledges,

In among the trees an' hedges,

Where, along by vlocks o' sparrows,

Chatt'rèn at the ploughman's harrows,

Dousty rwoaded,

Errand-lwoaded;

Jenny, though her cloak is thin,

Do wish en hwome upon the pin.

Zoo come along, noo longer heedvul

Over grass o' slopèn leäzes, meadows

Zingèn zongs in zunny breezes;

Out to work in copse, a-mootèn,

Where the primrwose is a-shootèn,

An' in gladness,

Free o' sadness,

In the warmth o' Spring vorget

Leafless winter's cwold an' wet. 
sprin

nə:u ðə Zıni æIrz əblo:ən

spf(t)li o:vər flə:uərz əgro:ən

ən ðə sparrklən lə:ıt də kwıvər

pn ði ə:Ivibə:u ən rIvər

bliətən lamz wi wuli fjesız

nə:u də plæı ərınən rjesız

ən ðə sprinən

larks əzingən

lık ə dpt əvuər ðə klə:ud

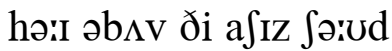

hə:uzən in ði o:bən brə:Itnis

nə:u də Si:n in sppts ə (h)wə:ItnIs

hiər ən ðعər pn $\Lambda$ plən(d) ledzIZ

In əmpy ðə tri:z ən hedzIz

(h)wər əlpy b(ə:)I vlpks ə sparə(r)z

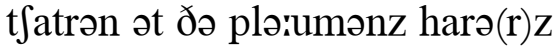

də:usti ruədid

erən(d)luədid

dzعni ðo: (h)ər kluək Iz ðın

də $\mathrm{WI} \int$ ən huəm əppn ðə pIn

zu: kım əlpy nu: longər hi:dvul

əv ðə və:ıər ljetli ni:dvul

o:vər gra:s ə slo:pən liəzIz

zIngən zDyz In ZAni bri:zIZ

ว:ut to wərrk in kpps əmutən

(h)wər ðə primruəz Iz əృutən

on in gladnis

fri: ə sadnis

In ðə wa:rm $\theta$ ə sprin vərget

li:flis wintərz kuəld ən wet 
As light do gleäre in ev'ry ground, field

Wi' boughy hedges out a-round

A-climmèn up the slopèn brows

O' hills, in rows o' sheädy boughs:

climbing

The while the hawthorn buds do blow

As thick as stars, an' white as snow;

Or cream-white blossoms be a-spread

About the guelder-rwoses' head;

How cool's the sheäde, or warm's the lewth,

shelter

Bezide a zummer hedge in blooth.

bloom

When we've a-work'd drough longsome hours, through

Till dew's a-dried vrom dazzlèn flow'rs,

The while the climmèn zun ha' glow'd

Drough mwore than half his daily road:

Then where the sheädes do slily pass

shadows

Athirt our veet upon the grass,

across

As we do rest by lofty ranks

Ov elems on the flow'ry banks;

How cool's the sheäde, or warm's the lewth,

Bezide a zummer hedge in blooth.

But oh! below woone hedge's zide

one

Our jaÿ do come a-most to pride;

Out where the high-stemm'd trees do stand,

In row bezide our own free land,

An' where the wide-leav'd clote mid zwim

'Ithin our water's rushy rim:

An' raïn do vall, an' zuns do burn,

An' each in season, and in turn,

To cool the sheäde or warm the lewth

Ov our own zummer hedge in blooth. 
ðə z^mər hed3

əz lə:It də gljeər In عvri grə:un(d)

wi bə:ui hedzIz ərut ərə:un(d)

əklımən $\Lambda$ р дә slo:pən brə:uz

ə hilz In ro:z ə $\int j \varepsilon d i$ bə:uz

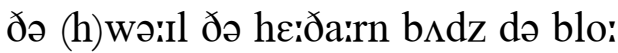

әz Өrk əz sta:rz ən (h)wərit əz sno:

ar kre:m(h)wə:It blpsəmz bi: əspred

əbə:ut ðə geldər ruəzız hed

hə:u ku:lz ðə Jjed ar wa:rmz ðə lu: $\theta$

bizə:Id ə zımər hedz in blu: $\theta$

(h)wen wi:v əwərrkt dru: lpysəm ə:uərz

trl dju:z ədrə:Id vrəm dazlən flə:uərz

ðə (h)wə:Il ðə klımən zムn hə glo:d

dru: muər ðən he:f (h)Iz de:li ro:d

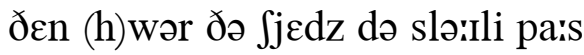

əðə:rt ə:uər vi:t әpрn ðə gra:s

əz wi: də rest b(ə:)I lpfti rayks

əv عləmz pn ðə flə;uri bayks

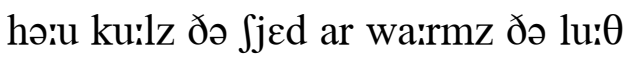

bizə:Id ə zımər hedz in blu: $\theta$

bət o: bilo: (w)u:n hedzIZ zə:Id

ə:uər dzæI də kım a:məst tə prə:Id

ə:ut (h)wər ðə hə:Istemd tri:z də stan(d)

In ro: bizə:Id ə:uər o:n fri: lan(d)

ən (h)wər ðə wə:Idli:vd klo:t mid zwım

IðIn ə:uər wə:tərz $\mathrm{r} \Lambda$ Si rım

ən ræIn də va:l ən z^nz də bə:rn

ən iit $\int$ in sizzən ən(d) in tə:rn

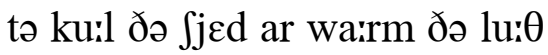

əv ə:uər o:n z^mər hedz in blu: $\theta$ 
How soft do sheäke the zummer hedge-

How soft do sway the zummer zedgeHow bright be zummer skies an' zunHow bright the zummer brook do run; An' feäir the flowers do bloom, to feäde Behind the swaÿen mower's bleäde;

An' sweet be merry looks o' jaÿ,

By weäles an' pooks o' June's new haÿ, ridges and cones

Wi' smilèn age, an laughèn youth,

Bezide the zummer hedge in blooth. 


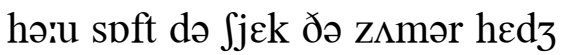
hə'u spft də swæı ðə zımər zed3

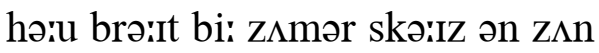

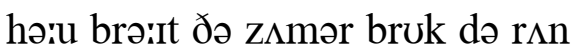
ən fjeər ðə flə:uərz də blu:m to fjed bihə:In(d) ðə swæıən mo:ərz bljed ən swi(:)t bi: meri luks ə dzæI b(ə:)I wjelz ən puks ə dzuinz nju: hæI wi smə:Ilən ع:d3 ən le:fən ju: $\theta$ bizə:Id ðə z^mər hed3 in blu: $\theta$ 
O SMALL-FEÄC'D flow'r that now dost bloom

To stud wi' white the shallow Frome,

An' leäve the clote to spread his flow'r

yellow water-lily

On darksome pools o' stwoneless Stour,

When sofly-rizèn aïrs do cool

The water in the sheenèn pool, shining

Thy beds o' snow-white buds do gleam

So feäir upon the sky-blue stream,

As whitest clouds, a-hangèn high

Avore the blueness o' the sky;

An' there, at hand, the thin-heäir'd cows,

In aïry sheädes o' withy boughs,

shadows, willow

Or up bezide the mossy rails,

Do stan' an' zwing their heavy tails,

The while the ripplèn stream do flow

Below the dousty bridge's bow;

dusty, arch

An' quiv'rèn water-gleams do mock

mimic

The weäves, upon the sheäded rock;

An' up athirt the copèn stwone

across

The laitren bwoy do leän alwone,

loitering

A-watchèn, wi' a stedvast look,

The vallèn waters in the brook,

The while the zand o' time do run

An' leäve his errand still undone.

An' oh! as long's thy buds would gleam

Above the softly-slidèn stream,

While sparklèn zummer-brooks do run

Below the lofty-climèn zun,

high-climbing

I only wish that thou could'st staÿ

falling

Vor noo man's harm, an' all men's jaÿ. 
ðə wə:tər kro:vut

o: sma:lfjest flə;uər ðət nə:u dəst blu:m tə st $\Lambda$ d wi (h)wə:It ðə Jalər fru:m ən liəv ðə klo:t to spred (h)Iz flə:uər pn darksəm pu:lz ə stuənlıs stə:uər (h)wen spflirə:Izən æIrz də ku:l ðə wə:tər in ðə Ji:nən pu:l ðə:I bedz ə sno:(h)wə:It bıdz də gli:m sə fjeər əppn ठə skə:Iblu: stri:m əz (h)wə:ItIst klə:udz əhayən hə:I әvuər ðə blu:nıs ə ðə skə:I ən ठər ət han(d) ðə ðInhjeərd kə;uz In æIri $\int j \varepsilon d z$ ə wiði bə:uz ar $\Lambda$ p bizə:Id ðə mpsi ræilz də stan ən zwin ठər hevi tæilz ðə (h)wə:ıl ðə riplən stri:m də flo: bılo: ðə də:usti brıdzız bo: ən kwivrən woitərgli:mz də mpk

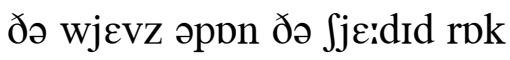
әn $\Lambda$ р əðə:rt ðə ko:pən stuən ðə læitrən bwə:I də liən əluən

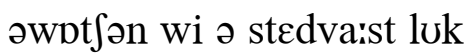
ðə va:lən wo:tərz in ðə bruk ðə (h)wə:Il ठə zan(d) ə tə:Im də rın ən liəv (h)Iz Erən(d) strl $\Lambda$ nd $\Lambda$ n ən o: əz lpyz ðə:I bıdz wud gli:m əb $\Lambda$ v ðə spf(t)lislə:Idən stri:m (h)wəril spa:rklən zımərbruks də rın bılo: ðə lpftiklımən z^n ə:I o:nli wI ðət ðə:u kudst stæI vər nu: manz ha:rm ən a:l menz dzæI 
But no, the waterman 'ull weäde

Thy water wi' his deadly bleäde,

To slay thee even in thy bloom,

Fair small-feäced flower o' the Frome. 
bət no: ðə wə:tərman ul wjed

ðə:I wə:tər wi (h)Iz dedli bljed

tə slæı ði: i:vən In ðə:I blu:m

fjeər sma:lfjest flə:uər ə ðə fru:m 
THE LILAC

DEAR lilac-tree, a-spreadèn wide

Thy purple blooth on ev'ry zide, bloom

As if the hollow sky did shed

Its blue upon thy flow'ry head;

Oh! whether I mid sheäre wi' thee

Thy open aïr, my bloomèn tree,

Or zee thy blossoms vrom the gloom,

'Ithin my zunless workèn-room,

My heart do leäp, but leäp wi' sighs,

At zight o' thee avore my eyes,

For when thy grey-blue head do swaÿ

In cloudless light, 'tis Spring, 'tis Maÿ.

'Tis Spring, 'tis Maÿ, as Maÿ woonce shed

His glowèn light above thy head-

When thy green boughs, wi' bloomy tips,

Did sheäde my childern's laughèn lips;

A-screenèn vrom the noonday gleäre

Their rwosy cheäks an' glossy heäir;

The while their mother's needle sped,

Too quick vor zight, the snow-white thread,

Unless her han', wi' lovèn ceäre,

Did smooth their little heads o' heäir;

Or wi' a sheäke, tie up anew

Vor zome wild voot, a slippèn shoe;

An' I did leän bezide thy mound

Ageän the deäsy-dappled ground,

The while the woaken clock did tick

made of oak

My hour o' rest away too quick, 
ðə lə:Ilək

diər lə:Iləktri: əspredən wə:Id ðə:I pə:rpol blu: $\theta$ pn $\varepsilon v$ ri zə:Id əz If ðə hplər skə:I did $\int \varepsilon d$ Its blu: əppn ðə:I flə:uri hed o: (h)weðər ə:I mId Sjeər wi ði: ðə:I o:bən æIr mə:I blu:mən tri: ar zi: ðə:I blpsəmz vrəm ðə glu:m IðIn mə:I Z^nlıs wərrkənru:m mə:I ha:rt də liəp bət liəp wi sə:Iz ət zə:It ə ði: əvuər mə:I ə:IZ vər (h)wen ðə:I gre:blu: hed də swæI In klə:udlıs lə:it tız sprin tız mæi

tIz sprin tIz mæi əZ mæi (w)uins $\int \varepsilon d$ (h)Iz glo:ən lə:It əb $\Lambda \mathrm{v}$ ðə:I hed (h)wen ðə:I gri:n bə:uz wi blu:mi trps did Sjed mə:I t IIldərnz le:fən lips əskri:nən vrəm ðə nu:nde: gljeər ðər ruəzi tfiəks ən glpsi hjeər ðə (h)wə:ıl ðər m^ðərz nIdəl sped tu: kwik vər zə:It ðə sno:(h)wə:It dred

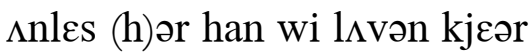
did smu:ð ðər litəl hedz ə hjeər

ar wi ə $\int j \varepsilon k$ tə:I $\Lambda$ p ənju:

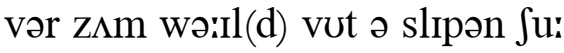
ən ə:I did liən bızə:Id ðə:I mə:un(d) əgjєn ðə djezidapəld grə:un(d) ðə (h)wə:Il ðə (w)uəkən klpk did tık mə:I ə:uər ə rest əwə:I tu: kwik 
An' call me off to work anew,

Wi' slowly-ringèn strokes, woone, two.

Zoo let me zee noo darksome cloud so

Bedim to-day thy flow'ry sh'oud, canopy

But let en bloom on ev'ry spraÿ, it Drough all the days o' zunny Maÿ. through 
ən ka:l mi: pf to wərk ənju:

wi slo:lirinon stro:ks (w)uin tu:

zu: let mi: zi: nu: da:rksəm klə:ud

bidim təde: ðə:I flə:uri 〔ə:ud

bət let ən blu:m pn evri spræI

dru: a:l ðə de:z ə zムni mæI 
THE BLACKBIRD [I]

'Twer out at Penley I'd a-past

A zummer day that went too vast, fast

An' when the zettèn zun did spread

On western clouds a vi'ry red, fiery

The elems' leafy limbs wer still

Above the gravel-bedded rill, An' under en did warble sh'ill, it, tunefully

Avore the dusk, the blackbird.

An' there, in sheädes o' darksome yews, shadows

Did vlee the maïdens on their tooes, fly, toes A-laughèn sh'ill wi' merry feäce loudly

When we did vind their hidèn pleäce,

'Ithin the loose-bough'd ivy's gloom,

Or lofty lilac, vull in bloom,

Or hazzle-wrides that gi'ed em room

Below the zingèn blackbird.

Above our heads the rooks did vlee

To reach their nested elem-tree, An' splashèn vish did rise to catch

The wheelèn gnots above the hatch;

An' there the miller went along,

A-smilèn, up the sheädy drong, gnats, wicket-gate

But yeet too deaf to hear the zong lane A-zung us by the blackbird.

An' there the sh'illy-bubblèn brook musically-

Did leäve behind his rocky nook,

To run drough meäds a-chill'd wi' dew, through

Vrom hour to hour the whole night drough; 
ðə blakbə:rd

twər ə:ut ət penli ə:Id əpaist

ə zムmər de: ðət went tu: va:st

ən (h)wen ठə zetən z^n did spred

pn westərn klə:udz ə və:iəri red

ði عləmz li:fi lımz wər stıl

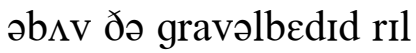

ən $\Lambda$ ndər ən did wa:rbəl $\int_{\mathrm{I}} \mathrm{l}$

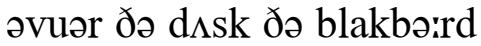

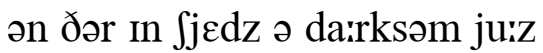

did vli: ðə mæidənz pn ðər tu:z əle:fən $\int \mathrm{Il}$ wi meri fjes

(h)wen wi: did və:In(d) ðər hə:Idən pljes

ıðın ðə lu:sbə:ud ə:Iviz glu:m

ar lpfti lə:ılək vul in blu:m

ar hazəlrə:Idz ðət gi:d əm ru:m

bilo: ðə zingən blakbərrd

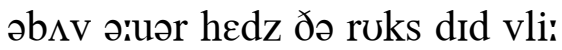

to ritt ठər nestıd عləmtri:

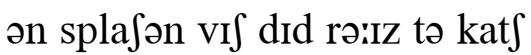

ðə (h)willən nats əb $\Lambda$ v ðə hat

ən ðər ðə milər went əlpy

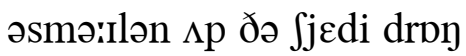

bət (j)it tu: def tə hiər ðə zDy

әzıy əs b(ə:)I ðə blakbə:rd

ən ðər ðə $\int \mathrm{Ilib}$ ¿blən bruk

did liəv bihə:In(d) (h)Iz roki nuk

to r $\Lambda$ dru: miədz ət $\int$ Ild wi dju:

vrəm ə:uər tə ə:uər ðə huəl nə:It dru: 
But still his murmurs wer a-drown'd

By vaïces that mid never sound

might

Ageän together on that ground,

Wi' whislèns o' the blackbird. 
bət strl (h)Iz mə:rmərz wər ədrə:und

b(ə:)I væIsIz ðət mId nevər sərund

әgjen təgeðər pn ðat grə:und

wi (h)wislənz ə ðə blakbə:rd 
AH! Jeäne, my maïd, I stood to you, daughter

When you wer christen'd, small an' light,

Wi' tiny eärms o' red an' blue,

arms

A-hangèn in your robe o' white.

We brought ye to the hallow'd stwone,

Vor Christ to teäke ye vor his own,

When harvest work wer all a-done,

An' time brought round October zun-

The slantèn light o' Fall.

An' I can mind the wind wer rough,

remember

An' gather'd clouds, but brought noo storms,

An' you did nessle warm enough,

'Ithin your smilèn mother's eärms.

arms

The whindlèn grass did quiver light, fragile

Among the stubble, feäded white,

An' if at times the zunlight broke

Upon the ground, or on the vo'k,

folk

'Twer slantèn light o' Fall.

An' when we brought ye drough the door

through

O' Knapton Church, a child o' greäce,

There cluster'd round a'most a score

O' vo'k to zee your tiny feäce.

An' there we all did veel so proud,

To zee an' op'nèn in the cloud,

An' then a stream o' light break drough,

A-sheenèn brightly down on you-

shining

The slantèn light o' Fall. 
ðə sle:ntən lə:It ə fa:l

a: dzjen mə:I mæid ə:I stud to ju:

(h)wen ju: wər krisənd sma:l ən lə:It wi tə:Ini ja:rmz ə red ən blu:

əhayən in jər ro:b ə (h)wə:It

wi: bro:t i: tə ðə halərd stuən vər krə:Ist to tjek i: var (h)Iz o:n (h)wen ha:rvist wərk wər ail əd $\Lambda$ n ən tə:Im bro:t rə:un(d) pkto:bər z $\Lambda$ n ðə sle:ntən lə:It ə fa:l

ən ə:I kən mə:In(d) ðə win(d) wər $\mathrm{r} \Lambda \mathrm{f}$ ən gaðərd klə:udz bət bro:t nu: sta:rmz ən ju: did nesəl warrm in $\Lambda f$ IðIn jər smə:Ilən m^ðərz ja:rmz ðə (h)windlən grais did kwivər lə:it әmpy ðə st $\Lambda$ bəl fjedid (h)wə:It ən If ət tə:Imz ðə zınlə:It bro:k әppn ðə grə:un(d) ar pn ðə vo:k twər sle:ntən lə:It ə fa:l

ən (h)wen wi: bro:t i: dru: ðə duər

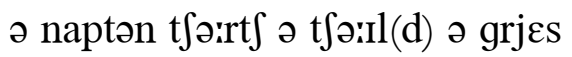
ðər klıstərd rə:un(d) a:məst ə skuər

ə vo:k tə zi: jər tə:Ini fjes ən ðər wi: a:l did vi:l sə prə:ud tə zi: ən o:bnən in ðə klə;ud ən ठعn ə stri:m ə lə:It bre:k dru:

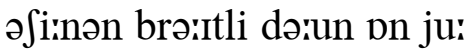
ðə sle:ntən lə:it ə fa:l 
But now your time's a-come to stand

In church, a-blushèn at my zide, The while a bridegroom vrom my hand

Ha' took ye vor his faithvul bride.

Your christèn neäme we gi'd ye here,

When Fall did cool the weästèn year;

An' now, ageän, we brought ye drough

wasting

The doorway, wi' your surneäme new, In slantèn light o' Fall.

An' zoo vur, Jeäne, your life is feäir, so far

An' God ha' been your steadvast friend, An' mid ye have mwore jaÿ than ceäre, may, joy

Vor ever, till your journey's end.

An' I've a-watch'd ye on wi' pride,

But now I soon mus' leäve your zide,

Vor you ha' still life's spring-tide zun,

But my life, Jeäne, is now a-run

To slantèn light o' Fall. 
bət nə:u jər tə:Imz ək $\wedge \mathrm{m}$ tə $\operatorname{stan}(\mathrm{d})$

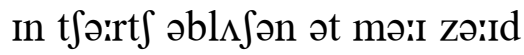

ðə (h)wə:Il ə brə:Idgru:m vrəm mə:I han(d)

ha tuk i: vər (h)Iz fæi $\theta v u l$ brə:Id

jər krıstən njem wi: gi(:)d i: hiər

(h)wen fa:l did kuil ðə wjestən jiər

ən nə:u əgjen wi: bro:t i: dru:

ðə duərwə:I wi jər sə:rnjem nju:

In sle:ntən lə:it ə fa:l

ən zu: və:r d3jen jər lə:If Iz fjeər

ən gpd hə bin jər stedvaist fren(d)

ən mId i: hav muər dzæI ðən kjeər

var Evər tıl jər dzərrniz en(d)

ən ว:IV əwptft i: pn wi pro:Id

bət nə:u ə:I suin mıs liəv jər zə:Id

var ju: ha stil lə:Ifs sprintə:Id zın

bət mə:I lə:If dzjen Iz nə:u ərیn

to sle:ntən lə:it ə fa:l 


\section{THISSLEDOWN}

THE thissledown by winds a-roll'd

In Fall along the zunny plain,

Did catch the grass, but lose its hold,

Or cling to bennets, but in vaïn.

grass-stalks

But when it zwept along the grass,

An' zunk below the hollow's edge,

It lay at rest while winds did pass

Above the pit-bescreenèn ledge.

The plaïn ha' brightness wi' his strife,

The pit is only dark at best,

There's pleasure in a worksome life,

An' sloth is tiresome wi' its rest.

Zoo, then, I'd sooner beär my peärt,

Ov all the trials vo'k do rue,

Than have a deadness o' the heart,

Wi' nothèn mwore to veel or do. 
ðIsəldə:un

ðə ðIsəldə:un b(ə:)I wIn(d)z əro:ld

In fa:l əlpy ðә zıni plæın

did kat ðə gra:s bət lu:z its huəld

ar klin tə benits bət in væin

bət (h)wen It zwept əlpy ðə gra:s

ən z^yk bilo: ðə hplərz $\varepsilon d 3$

It le: ət rest (h)wə:Il win(d)z did pa:s

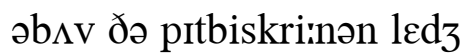

ðə plæIn ha brə:Itnis wi (h)Iz strə:If ðə pit IZ o:nli da:rk ət best

ðərz plezər In ə wərrksəm lə:If

ən $\operatorname{slp} \theta$ IZ tə:Iərsəm wi its rest

zu: ðعn ə:Id su:nər beər mə:I pja:rt

əv a:l ठə trə:ıəlz vo:k də ru:

ðən hav ə dednis ə ðə ha:rt

wi n $\Lambda \theta ə n$ muər to vi:l ar du: 
THE MAŸ-TREE

I'VE a-come by the Maÿ-tree all times o' the year,

When leaves wer a-springèn,

When vrost wer a-stingèn,

When cool-winded mornèn did show the hills clear,

When night wer bedimmèn the vields vur an' near.

far

When, in zummer, his head wer as white as a sheet,

Wi' white buds a-zwellèn,

An' blossom, sweet-smellèn,

While leaves wi' green leaves on his bough-zides did meet,

A-sheädèn the deäisies down under our veet.

When the zun, in the Fall, wer a-wanderèn wan,

An' haws on his head

Did sprinkle en red,

$$
\text { it }
$$

Or bright drops o' raïn wer a-hung loosely on,

To the tips o' the sprigs when the scud wer a-gone.

sudden shower

An' when, in the winter, the zun did goo low,

An' keen win' did huffle,

blow in gusts

But never could ruffle

The hard vrozen feäce o' the water below,

His limbs wer a-fringed wi' the vrost or the snow.

its 
ðə mæitri:

ə:IV əkım b(ə:)I ðə mæitri: a:l tə:Imz ə ðə jiər

(h)wen liivz wər əsprinən

(h)wen vrost wər əstıjən

(h)wen ku:lwindıd ma:rnən did fo: ðə hılz kliər

(h)wen nə:It wər bidımən ðə vi:l(d)z və:r ən niər

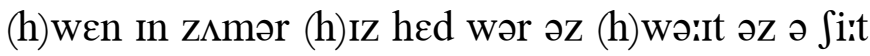

wi (h)wə:It bıdz əzwelən

ən blpsəm swi(:)tsmelən

(h)wə:Il liivz wi gri:n li:vz pn (h)Iz bə:uzə:Idz did mi:t

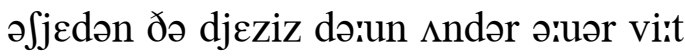

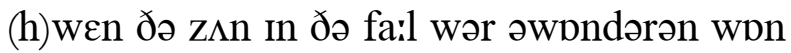

ən he:z pn (h)Iz hed

did sprinkəl ən red

ar brə:It draps ə ræIn wər əh $\Lambda$ y luisli pn

tə ðə tıps ə ðə sprigz (h)wعn ðə sk^d wər əgpn

ən (h)wعn In ðə wintər ðə z^n did gu: lo:

ən ki:n win(d) did h $\Lambda$ fəl

bət nevər kud rufəl

ðə ha:rd vro:zən fjes ə ðə wə:tər bilo:

(h)Iz limz wər əfrındzd wi ðə vrost ər ðə sno: 


\section{LYDLINCH BELLS}

WHEN skies wer peäle wi' twinklèn stars,

An' whislèn aïr a-risèn keen;

An' birds did leäve the icy bars

To vind, in woods, their mossy screen;

When vrozen grass, so white's a sheet,

Did scrunchy sharp below our veet,

An' water, that did sparkle red

At zunzet, wer a-vrozen dead;

The ringers then did spend an hour

A-ringèn changes up in tow'r;

Vor Lydlinch bells be good vor sound,

An' liked by all the naighbours round.

An' while along the leafless boughs

O' ruslèn hedges, win's did pass,

An' orts ov haÿ, a-left by cows,

Did russle on the vrozen grass,

An' maïdens' pails, wi' all their work

A-done, did hang upon their vurk,

An' they, avore the fleämèn brand,

Did teäke their needle-work in hand,

The men did cheer their heart an hour

A-ringèn changes up in tow'r;

Vor Lydlinch bells be good vor sound

An' liked by all the naïghbours round.

There sons did pull the bells that rung

Their mothers' weddèn peals avore,

The while their fathers led em young

An' blushèn vrom the churches door,

An' still did cheem, wi' happy sound,

chime

As time did bring the Zundays round, 
lidlint $b \varepsilon l z$

(h)wen skə:Iz wər pjel wi twinklən sta:rz

ən (h)wislən æIr ərə:Izən ki:n

ən bə:rdz did liəv ði ə:ısi ba:rz

tə və:In(d) In wudz ðər mpsi skri:n

(h)wen vro:zən gra:s sə (h)wə:Its ə ji:t

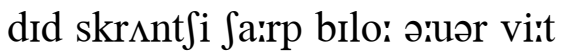

ən wo:tər ðət did spa:rkəl red

ət z^nzet wər əvro:zən ded

ðə rijərz ðعn did $\operatorname{sp\varepsilon n(d)~ən~ə:uər~}$

ərinən t tandzIz $\Lambda \mathrm{p}$ in tə:uər

vər lidlint belz bi: gud vər sə:un(d)

ən likt b(ə:)I a:l ðə næibərz rə:un(d)

ən (h)wəril əlpy ðə li:flıs bə:uz

ə rıslən hedzIz winz did pais

ən a:rts əv hæi əleft b(ə:)I kə:uz

did rusəl pn ðə vro:zən gra:s

ən mæIdənz pæılz wi a:l ðər wərrk

əd $\Lambda$ n did hay əppn ðər vərrk

ən ðе: әvuər ðə fljemən bran(d)

did tjek ðər nIdəlwərrk in han(d)

ðə men did tfiər ðər hairt ən ə:uər

ərinən t tandzIZ $\Lambda \mathrm{p}$ in tə:uər

vər lidlint belz bi: gud vər sə:un(d)

ən likt b(ə:)I a:l ðə næibərz rə:un(d)

ðعər sınz did pul ðə belz ðət r $\wedge$ y

ðər m^ðərz wedən pi:lz əvuər

ðə (h)wə:Il ðər fe:ðərz led əm j $\Lambda$ y

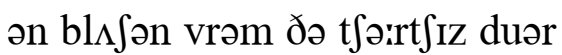

ən strl did t $\int i: m$ wi hapi sərun(d)

əz tə:Im did brı⿰ ðə z^nde:z rə:un(d) 
An' call em to the holy pleäce

Vor heav'nly gifts o' peace an' greäce;

An' vo'k did come, a-streamèn slow

Along below the trees in row,

While they, in merry peals, did sound

The bells vor all the naïghbours round.

An' when the bells, wi' changèn peal,

Did smite their own vo'ks window-peänes,

Their sof en'd sound did often steal

Wi' west winds drough the Bagber leänes;

through

Or, as the win' did shift, mid goo

Where woody Stock do nessle lew,

sheltered

Or where the risèn moon did light

The walls o' Thornhill on the height;

An' zoo, whatever time mid bring

so

To meäke their vive clear vaïces zing,

Still Lydlinch bells wer good vor sound,

An' liked by all the naighbours round. 
ən ka:l əm tə ðə ho:li pljes

vər hevnli gifts ə piss ən grjes

ən vo:k did kım əstri:mən slo:

əlpy bilo: ðə triiz in ro:

(h)wə:Il ðе: In meri pi:lz did sə:un(d)

ðə belz vər a:l ðə næibərz rə:un(d)

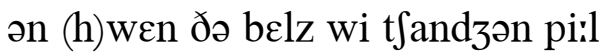

did smə:It ðər o:n vo:ks windərpjenz

ðər spfən(d) sə:un(d) did pfən sti:l

wi west win(d)z dru: ðə bagbər ljenz

ar az ठə win(d) did Jift mid gu:

(h)wər wudi stpk də nesəl lu:

ar (h)weər ðə rə:Izən mu:n did lə:It

ðə wa:lz ə ða:rnhıl pn ðə hə:It

ən zu: (h)wptevər tə:Im mid brin

tə mjєk ठər və:IV kliər væIsIz zIn

stıl lidlint $\int$ belz wər gud vor sə:un(d)

ən likt b(ə:)I a:l ठə næibərz rə:un(d) 
AH! when the wold vo'k went abroad

old folk, out

They thought it vast enough, fast

If vow'r good ho'ses beät the road

four, horses

Avore the coach's ruf;

roof

An' there they zot, sat

A-cwold or hot,

An' roll'd along the ground,

While the whip did smack

On the ho'ses' back,

An' the wheels went swiftly round, Good so's;

The wheels went swiftly round.

souls (friends)

Noo iron rails did streak the land

To keep the wheels in track.

The coachman turn'd his vow'r-in-hand,

Out right, or left, an' back;

An' he'd stop avore

A man's own door,

To teäke en up or down:

bim

While the reïns vell slack

On the ho'ses' back,

Till the wheels did rottle round ageän;

Till the wheels did rottle round.

An' there, when wintry win' did blow,

Athirt the plain an' hill, across

An' the zun wer peäle above the snow,

An' ice did stop the mill,

They did laugh an' joke

Wi' cwoat or cloke,

So warmly roun' em bound, 
ðə stع:d3 ko:t $\int$

a: (h)wen ðə (w)uəld vo:k went əbro:d ðе: ðo:t It va:st in $\Lambda f$

If və:uər gud hpsiz biət ðə ro:d әvuər ठə ko:t $\int \mathrm{Iz} \mathrm{r} \Lambda \mathrm{f}$ ən ðər ðe: zat əkuəld ər hpt

ən ro:ld əlpy ðə grə:un(d)

(h)wə:Il ðә (h)wıp did smak pn ðə hpsiz bak ən ðə (h)wi:lz went swif(t)li rə:un(d) gud so:z ðə (h)wi:lz went swif(t)li rə:un(d)

nu: ə:ıərn ræIlz dıd striik ðə lan(d)

to ki(:)p ðə (h)wi:lz In trak

ðə ko:t mən tə:rnd (h)IZ və:uərınhan(d)

ə:ut rə:it ər left on bak

ən əd stpp əvuər

ə manz o:n duər

tə tjek on $\Lambda p$ ər dərun

(h)wə:Il ðə ræInz vel slak

pn ðə hpsiz bak

tıl ðə (h)wi:lz dıd rotəl rə:un(d) əgjen

tıl ðə (h)willz did rotəl rə:un(d)

ən ðər (h)wen wintri win did blo:

әðə:rt ðə plæın ən hil

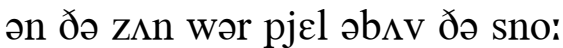

ən ə:Is did stpp ðə mil

ðe: did le:f on dzo:k

wi kuət ər klo:k

sə wa:rmli rə:un əm bə:un(d) 
While the whip did crack

On the ho'ses' back,

An' the wheels did trundle round, d'ye know;

The wheels did trundle round.

An' when the rumblèn coach did pass

Where hufflèn winds did roar, gusty

They'd stop to teäke a warmèn glass

By the sign above the door;

An' did laugh an' joke

An' ax the vo'k

ask, folk

The miles they wer vrom town,

Till the whip did crack

On the ho'ses back,

An' the wheels did truckle roun', good vo'k;

The wheels did truckle roun'.

An' gaily rod wold age or youth,

rode, old

When zummer light did vall

On woods in leaf, or trees in blooth,

bloom

Or girt vo'ks parkzide wall.

great

An' they thought they past

The pleäces vast,

Along the dousty groun',

When the whip did smack

dusty

On the ho'ses' back,

An' the wheels spun swiftly roun'. Them days

The wheels spun swiftly roun'. 
(h)wə:Il ðə (h)wıp did krak

pn ðə hpsiz bak

ən ðə (h)wi:lz did trındəl rə:un(d) dji: no:

ðə (h)willz did trındəl rə:un(d)

ən (h)wen ðə rımblən ko:t $\int$ did pa:s

(h)wər $\mathrm{h} \Lambda$ flən win(d)z did ruər

ðe:d stpp to tjek ə wa:rmən gla:s

b(ə:)I ðə sə:In əb $\Lambda \mathrm{v}$ ðə duər

ən did le:f on dzo:k

ən a:ks ðə vo:k

ðə mə:Ilz ðе: wər vrəm tə:un

tıl ðə (h)wıp did krak

pn ठə hpsiz bak

ən ðə (h)wi:lz did trıkəl rə:un gud vo:k

ðə (h)willz did trıkəl rə:un

ən gæili rod (w)uəld $\varepsilon: d 3$ ər ju: $\theta$

(h)wen zımər lə:It did va:l

pn wudz in li:f ar tri:z in blu: $\theta$

or gərrt vo:ks pa:rkzə:Id wa:l

ən ðе: ðo:t ðe: pa:st

ðə pljesız vaist

əlpy ðə də:usti grə:un

(h)wen ðə (h)wıp did smak

pn ðə hpsiz bak

ən ðə (h)wi:lz sp^n swIf(t)li rə:un ðعm de:z

ðə (h)wi:lz sp^n swif(t)li rə:un 


\section{WAYFEÄRÈN}

THE sky wer clear, the zunsheen glow'd sunsbine

On droopèn flowers drough the day, As I did beät the dousty road through dusty

Vrom hinder hills, a-feädèn gray;

Drough hollows up the hills, Vrom knaps along by mills, billocks Vrom mills by churches tow'rs, wi' bells That twold the hours to woody dells.

An' when the windèn road do guide

The thirsty vootman where mid flow may

The water vrom a rock bezide

His vootsteps, in a sheenèn bow;

shining

The hand a-hollow'd up

Do beät a goolden cup,

To catch an' drink it, bright an' cool, A-vallèn light 'ithin the pool.

falling

Zoo when, at last, I hung my head so

Wi' thirsty lips a-burnèn dry, I come bezide a river-bed

Where water flow'd so blue's the sky;

An' there I meäde me up

O' coltsvoot leaf a cup,

Where water vrom his lip o' gray,

Wer sweet to sip thik burnèn day.

that

But when our work is right, a jay

Do come to bless us in its traïn, An' hardships ha' zome good to paÿ

The thoughtvul soul vor all their païn: 
wə:Ifjeərən

ðə skə:ı wər kliər ðə z^nfiin glo:d

pn dru:pən flə:uərz dru: ðə de:

əZ ə:I did biət ðə də:usti ro:d

vrəm hə:Indər hilz əfjedən gre:

dru: hplərz $\Lambda p$ ðə hilz

vrəm naps əlpy b(ə:)I milz

vrəm milz b(ə:) I t $\int$ ərrt $\int \mathrm{Iz}$ tə:uərz wi belz

ðət tuəld ði ə:uərz tə wudi delz

ən (h)wยn ðə wə:In(d)ən ro:d də gə:Id

ðə ðə:rsti vutmən (h)wər mid flo:

ðə wo:tər vrəm ə rok bizə:Id

(h)IZ vutsteps in ə Ji:nən bo:

ðə han(d) əhplərd $\Lambda \mathrm{p}$

də biət ə gu:ldən kıp

to kat ən drink it brə:It ən ku:l

əva:lən lə:ıt ıðın ðə pu:l

zu: (h)wen ət le:st ə:I h^y mə:I hed

wi ðə:rsti lips əbə:rnən drə:I

ə:I kım bizəiıd ə rivərbed

(h)wər wə:tər flo:d sə blu:z ðə skə:I

ən ठər ə:I mjed mi: $\Lambda p$

ə ko:ltsvut li:f ə kıp

(h)wər wo:tər vrəm (h)Iz lip ə gre:

wər swi(:)t tə sip ðık bə:rnən de:

bət (h)wen ə:uər wə:rk IZ rə:It ə dzæI

də kım to bles əs In Its træIn

ən ha:rdfips ha zım gud tə pæI

ðə Өo:tvul so:l vər a:l ðər pæin 
The het do sweetèn sheäde,

An' weary lim's ha' meäde

A bed o' slumber, still an' sound,

By woody hill or grassy mound.

An' while I zot in sweet delaÿ

sat

Below an elem on a hill,

Where boughs a-halfwaÿ up did swaÿ

In sheädes o' lim's above em still,

shadows

An' blue sky show'd between

The flutt'rèn leäves o' green;

I woulden gi'e that gloom an' sheäde

give

Vor any room that weälth ha' meäde.

But oh! that vo'k that have the roads folk

Where weary-vooted souls do pass,

Would leäve bezide the stwone vor lwoads,

A little strip vor zummer grass;

That when the stwones do bruise

An' burn an' gall our tooes,

toes

We then mid cool our veet on beds

may

O' wild-thyme sweet, or deäisy-heads. 
ðə hદt də swi(:)tən $\int j \varepsilon d$

ən wiəri limz hə mjed

ə bed ə slımbər stıl ən sə:un(d)

b(ə:)I wudi hil ər graisi mə:un(d)

ən (h)wว:Il ว:I zat In swi(:)t dilæI

bilo: ən عləm pn ə hil

(h)wər bə:uz əhe:fwə:I $\Lambda p$ did swæI

In $\int j \varepsilon d z$ ə limz əb $\Lambda \mathrm{v}$ əm stıl

ən blu: skə:I fo:d bitwi:n

ðə flıtrən liivz ə gri:n

ə:I (w)Udən gi: ðat glu:m ən jjed

vər $\varepsilon$ ni ru:m ðət wel $\theta$ hə mjed

bst o: ðət vo:k ðət hav ðə ro:dz

(h)wər wiərivutid so:lz də pa:s

wud liəv bizəiId ðə stuən vər luədz

ə litəl strip vər zımər gra:s

ðət (h)wen ðə stuənz də bru:z

ən bə:rn ən ga:l ə:uər tu:z

wi: ðعn mid ku:l ə:uər viit pn bedz

ə wə:Il(d)tə:Im swi:t ar djezihedz 
THEY do zay that a travellèn chap

Have a-put in the newspeäper now,

That the bit o' green ground on the knap

billock.

Should be all a-took in vor the plough.

He do fancy 'tis easy to show

That we can be but stunpolls at best,

Vor to leäve a green spot where a flower can grow,

Or a voot-weary walker mid rest.

blockheads

'Tis hedge-grubbèn, Thomas, an' ledge-grubbèn,

Never a-done

While a sov'rèn mwore's to be won.

sovereign

The road, he do zay, is so wide

As 'tis wanted vor travellers' wheels,

As if all that did travel did ride,

An' did never get galls on their heels.

He would leäve sich a thin strip o' groun',

That, if a man's veet in his shoes

Wer a-burnèn an' zore, why he coulden zit down

But the wheels would run over his tooes.

toes

Vor 'tis meäke money, Thomas, an' teäke money,

What's zwold an' bought

Is all that is worthy o' thought.

Years agoo the leäne-zides did bear grass,

Vor to pull wi' the geeses' red bills,

That did hiss at the vo'k that did pass,

folk

Or the bwoys that pick'd up their white quills.

But shortly, if vower or vive

four or five

Ov our goslèns do creep vrom the agg,

They must mwope in the geärden, mwore dead than alive,

In a coop, or a-tied by the lag. 
ðə ljen

ðe: də ze: ðət ə travələn t $\mathrm{t} a \mathrm{p}$

hav әp^t in ðə njuispjepər nə:u

ðat ðə bit ə gri:n grə:un(d) pn ðə nap

Sud bi: a:l ətuk in vər ðə plə:u

hi: də fansi tız i:zi to Jo:

ðət wi: kan bi: bət stınpo:lz ət best

var to liəv ə gri:n sppt (h)wər ə flə:uər kən gro:

or ə vutwiəri we:kər mId rest

tIz hed3 gr $\Lambda$ bən toməs ən led3 gr

$$
\text { nevər əd } \Lambda n
$$

(h)wə:il ə spvrən muərz tə bi: wan

ðə ro:d ə də ze: IZ sə wə:Id

az tIz wontId vər travələrz (h)willz

az If a:l ठət did travəl did rə:Id

ən did nevər get ga:lz pn ðər hi:lz

hi: wud liəv sit $\int$ ə ðIn strip ə grəiun

ðat If ə manz viit in (h)Iz Ju:z

wər əbərrnən ən zuər (h)wə:I ə kudən zit də‘un

bət ðə (h)wi:lz wud rın ə:vər (h)Iz tu:z

vər tız mjek mıni tpməs ən tjek mıni

(h)wpts zuəld on boit

IZ a:l ðət IZ wə:rði ə ðว:t

jiərz əgu: ðə ljen zə:Idz did beər gra:s

var to pul wi ðə giisiz red bilz

ðat did his ət ðə vo:k ðət did pais

ar ðə bwə:Iz ðət pikt $\Lambda$ p ðər (h)wə:It kwılz

bət Sa:rtli If və:uər ər və:IV

əv ə:uər gpzlənz də kri:p vrəm ði ag

ðе: məst muəp In ðə gja:rdən muər ded ðən ələ:IV

In ə ku:p ar ətə:Id b(ə:)I ðə lag 
Vor to catch at land, Thomas, an' snatch at land,

Now is the plan;

Meäke money wherever you can.

The childern wull soon have noo pleäce

Vor to plaÿ in, an' if they do grow,

They wull have a thin musheroom feäce,

Wi' their bodies so sumple as dough.

soft

But a man is a-meäde ov a child,

An' his limbs do grow worksome by plaÿ;

An' if the young child's little body's a-spweil'd,

spoiled

Why, the man's wull the sooner decaÿ.

But wealth is wo'th now mwore than health is wo'th;

worth

Let it all goo,

If't 'ull bring but a sov'rèn or two.

Vor to breed the young fox or the heäre, bare

We can gi'e up whole eäcres o' ground, give, acres

But the greens be a-grudg'd, vor to rear

Our young childern up healthy an' sound,

Why, there woont be a-left the next age

A green spot where their veet can goo free;

An' the goocoo wull soon be committed to cage

cuckoo

Vor a trespass in zomebody's tree.

Vor 'tis lockèn up, Thomas, an' blockèn up,

Stranger or brother,

Men mussen come nigh woone another.

one

Woone day I went in at a geäte,

Wi' my child, where an echo did sound,

An' the owner come up, an' did reäte

abuse

Me as if I would car off his ground.

carry

But his vield an' the grass wer a-let,

An' the damage that he could a-took 
var to kat $\int$ ət lan(d) tpməs ən snat 2 t lan(d) nə'u Iz ðə plan

mjek m^ni (h)wərevər jə kan

ðə t fildərn wol su:n hav nu: pljes

var tə plæi In ən If ðe: də gro:

ðе: wul hav ə ðın $m \Lambda \int ə r u: m$ fjes

wi ðər bpdiz sə sımpəl əz do:

bət ə man IZ əmjed əv ə tfə:Ild

ən (h)Iz limz də gro: wə:rksəm b(ə:)I plæI

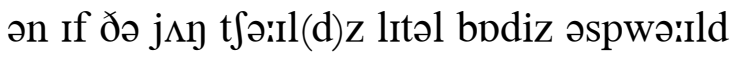

(h)wə:ı ðə manz wul ðə su:nər dikæI

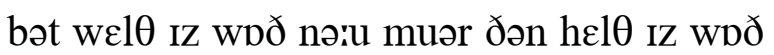

let it a:l gu:

If tul brin bət a spvrən ar tu:

var tə bri:d ðə j^y fpks ar ðə hjeər

wi: kən gi: $\Lambda$ p huəl jekərz ə grəun(d)

bət ðə gri:nz bi: əgrıdzd vər to reər

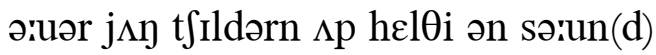

(h)wə:I ठər wu(:)nt bi: əleft ðə neks(t) $\varepsilon: d 3$

ə gri:n sppt (h)wər ðər vi:t kən gu: fri:

ən ðə guku: wul su:n bi: kəmitid tə ke:d3

vər a trespa:s In zムmbpdiz tri:

var tIz lpkən $\Lambda$ p tpməs ən blpkən $\Lambda$ p

strandzər ər br $\Lambda$ ðr

men mısən kım nə:I (w)u:n ən^ðər

(w)u:n de: ə:I went in ət ə gjet

wi mə: t ţəril(d) (h)wər ən عko: did sərun(d)

ən ठi o:nər kım $\Lambda p$ ən did rjet

mi: az If ə:I wud kair pf (h)Iz grəiun(d)

bət (h)Iz vi:l(d) ən ðə gra:s wər əlet

ən ðə damıdz ðat hi: kud ətuk 
Wer at mwost that the while I did open the geäte

I did rub roun' the eye on the hook.

But 'tis drevèn out, Thomas, an' hevèn out.

driving, heaving

Trample noo grounds,

fields

Unless you be after the hounds.

Ah! the Squiër o’ Culver-dell Hall

Wer as diff rent as light is vrom dark,

Wi' zome vo'k that, as evenèn did vall,

Had a-broke drough long grass in his park;

folk

through

Vor he went, wi' a smile, vor to meet

Wi' the trespassers while they did pass,

An' he zaid, "I do fear you'll catch cwold in your veet,

You've a-walk'd drough so much o' my grass."

His mild words, Thomas, cut em like swords, Thomas,

Newly a-whet,

An' went vurder wi' them than a dreat.

further 
wər ət muəst ðat ðə (h)wə:Il ə:I did o:bən ðə gjet ə:I did r $\Lambda$ b rə:un ði ə:I pn ðə huk bət tIz dre:vən ə:ut toməs ən heivən ərut trampəl nu: grə:un $(\mathrm{d}) \mathrm{z}$

^nles jə bi: ع:tər ðə hə:un(d)z

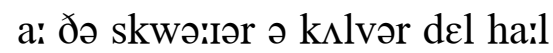
wər əz difrənt əz lə:It IZ vrəm dark wi zım vo:k ðat az i:vmən did va:l

had əbro:k dru: lpy gra:s in (h)Iz parrk var hi: went wi ə smə:il var to mi:t wi ðə trespa:sərz (h)wə:ıl ðe: did pa:s ən hi: zed əiI də fiər jəl kat kuəld in jər vi:t jəv əwe:kt dru: sə mıt $\int$ ə mə:I gra:s (h)Iz mə:Ild wərrdz tpməs kıt əm lik suərdz tpməs nju:li $\partial(\mathrm{h}) \mathrm{wet}$ ən went və:rdər wi ðعm ðən ə dret 
THE RAÏLROAD [1]

I TOOK a flight, awhile agoo,

Along the rails, a stage or two,

An' while the heavy wheels did spin

An' rottle, wi' a deafnèn din,

In clouds o' steam, the zweepèn train

Did shoot along the hill-bound plain,

As sheädes o' birds in flight, do pass

shadows

Below em on the zunny grass.

An' as I zot, an' look'd abrode

sat, about

On leänen land an' windèn road,

The ground a-spread along our flight

Did vlee behind us out o' zight;

The while the zun, our heav'nly guide,

Did ride on wi' us, zide by zide.

An' zoo, while time, vrom stage to stage,

Do car us on vrom youth to age, carry

The e'thly pleasures we do vind earthly

Be soon a-met, an' left behind;

But God, beholdèn vrom above

Our lowly road, wi' yearnèn love,

Do keep bezide us, stage by stage,

Vrom be'th to youth, vrom youth to age.

birth 
ðə ræılro:d

ว:I tuk ə flə:It ə(h)wə:Il əgu:

əlpy ðə ræilz ə ste:d3 ər tu:

ən (h)wərIl ðə hevi (h)wi:lz did spın

ən rotəl wi ə defnən din

In klə:udz ə sti:m ðə zwi:pən træın

did Sut əlpy ðə hilbə:un(d) plæIn

əz $\int j \varepsilon d z$ ə bə:rdz In flə:It də pa:s

bılo: əm pn ðə zムni gra:s

ən az ə:I zat on lukt əbro:d

pn liənən lan(d) ən wə:In(d)ən ro:d

ðə grə:un(d) əspred əlpy ə:uər flə:It

did vli: bihə:In(d) əs ə:ut ə zə:It

ðə (h)wə:Il ðə z^n ə:uər hevnli gə:Id

did rə:Id pn wi əs zə:Id b(ə:)I zə:Id

ən zu: (h)wə:Il tə:Im vrəm ste:d3 to ste:d3

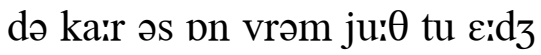

ði $\varepsilon \theta 1 i$ plezərz wi: də və:In(d)

bi: suin əmet ən left bihə:In(d)

bət gpd bihuəldən vrəm əb $\Lambda \mathrm{v}$

ə:uər lo:li ro:d wi ja:rnən $1 \Lambda \mathrm{v}$

də ki(:)p bizə:Id əs ste:dz b(ə:)I ste:d3

vrəm be $\theta$ tə ju: $\theta$ vrəm ju: $\theta$ tu $\varepsilon: d 3$ 
THE RAÏLROAD [II]

AN' while I went 'ithin a traï,

A-ridèn on athirt the plaïn,

across

A-cleärèn swifter than a hound,

On twin-laid rails, the zwimmèn ground;

I cast my eyes 'ithin a park,

Upon a woak wi' grey-white bark,

An' while I kept his head my mark,

The rest did wheel around en.

oak

its

it

An' when in life our love do cling

The clwosest round zome single thing,

We then do vind that all the rest

Do wheel roun' that, vor vu'st an best;

first

Zoo while our life do last, mid nought

so, may

But what is good an' feäir be sought,

In word or deed, or heart or thought,

An' all the rest wheel round it. 
ðə ræılro:d

ən (h)wว:Il ə:I went IðIn ə træIn

ərə:Idən pn əðə:rt ðə plæın

əkliərən swiftər ðən ə hə:un(d)

pn twinled ræilz ðə zwımən grə:un(d)

ə:I ka:st mə:I ə:Iz ıðın ə pa:rk

əppn ə (w)uək wi gre:(h)wə:It ba:rk

ən (h)wə:Il ə:I kept (h)Iz hed mə:I ma:rk

ðə rest did (h)will ərə:un(d) ən

ən (h)wen In lə:If ə:uər $1 \Lambda \mathrm{v}$ də klın

ðə kluəsist rə:un(d) zムm singəl ðın

wi: ðعn də və:In(d) ðət a:l ðə rest

də (h)will rə:un ðat vər vıst ən best

zu: (h)wə:Il ə:uər lə:If də le:st mid no:t

bət (h)wot Iz gud on fjeər bi: soit

In wərrd ər di:d ər ha:rt ər ðo:t

ən a:l ðə rest (h)will rə:un(d) It 
SEATS

WHEN starbright maïdens be to zit

In silken frocks, that they do wear,

The room mid have, as 'tis but fit,

A han'some seat vor vo'k so feäir;

But we, in zun-dried vield an' wood,

Ha' seats as good's a goolden chair.

Vor here, 'ithin the woody drong, may folk

A ribbèd elem-stem do lie,

lane

elm-trunk

A-vell'd in Spring, an' stratch'd along

A bed o' grægles up knee-high,

bluebells

A sheädy seat to rest, an' let

The burnèn het o' noon goo by.

beat

Or if you'd look, wi' wider scope,

Out where the gray-tree'd plain do spread,

The ash bezide the zunny slope,

Do sheäde a cool-aïr'd deäisy bed,

An' grassy seat, wi' spreadèn eaves

O' rus'lèn leaves, above your head.

An' there the train mid come in zight,

Too vur to hear a-rollèn by,

A-breathèn quick, in heästy flight,

His breath o' tweil, avore the sky,

toil

The while the waggon, wi' his lwoad,

Do crawl the rwoad a-winden nigh.

Or now theäse happy holiday

this

Do let vo'k rest their weary lim's, An' lwoaded haÿ's a-hangèn gray,

Above the waggon-wheels' dry rims, 
sits

(h)wen sta:rbrə:It mæIdənz bi: tə zit

In silkən froks ðət ðe: də weər

ðə ru:m mid hav az tiz bət fit

ə hansəm si:t vər vo:k sə fjeər

bət wi: In z^ndrə:Id vi:l(d) ən wud

ha si:ts əz gudz ə guildən t teər

var hiər ıðın ðə wudi dron

ə ribəd عləmstem də lə:I

əveld In sprin ən stratft əlpy

ə bed ə gre:gəlz $\Lambda$ p ni:hə:I

ə $\int j \varepsilon d i$ siit to rest on let

ðə bə:rnən het ə nu:n gu: bə:I

ar If ju:d luk wi wə:Idər sko:p

ə:ut (h)wər ðə gre:tri:d plæIn də spred

ði a bizə:Id ðə z^ni slo:p

də Jjed ə ku:lærrd djezi bed

ən gra:si sitt wi spredən i:vz

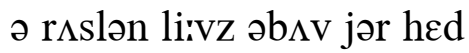

ən ðər ðə træın mId k^m in zə:It

tu: və:r to hiər əro:lən bə:I

əbri:ðən kwik in hjesti flə:It

(h)Iz bre $\theta$ ə twə:Il əvuər ðə skə:I

ðə (h)wə:Il ðə wagən wi (h)rz luəd

də kra:l ðə ruəd əwə:In(d)ən nə:I

ar nə'u ðiəs hapi holıde:

do let vo:k rest ðər wiəri limz

ən luədıd hæız əhayən gre:

əbムv ðə wagən(h)wi:lz drə:I rImz 
The meäd ha' seats in weäles or pooks,

By windèn brooks, wi' crumblèn brims.

Or if you'd gi'e your thoughtvul mind

To yonder long-vorseäken hall,

Then teäke a stwonèn seat behind

stone

The ivy on the broken wall,

An' learn how e'thly wealth an' might

earthly

Mid clim' their height, an' then mid vall.

may climb 
ðə miəd ha siits in wjelz ər puks

b(ə:)I Wə:In(d)ən bruks wi kr^mblən brımz

ar If ju:d gi: jər $\theta$ stvul mə:In(d)

to jandər loyvarsjekən ha:l

ðદn tjek ə stuənən si:t bihə:In(d)

ði ə:Ivi pn ðə bro:kən wa:l

ən la:rn hə:u $\varepsilon \theta$ li wel $\theta$ ən mə:It

mıd klım ðər hə:It ən ðعn mid va:l 
SOUND O' WATER

I BORN in town! oh no, my dawn

O' life broke here beside theäse lawn;

this glade

Not where pent aïr do roll along,

In darkness drough the wall-bound drong,

An' never bring the goo-coo's zong,

through, lane

cuckoo's

Nor sweets o' blossoms in the hedge,

Or bendèn rush, or sheenèn zedge, shining

Or sounds o' flowèn water.

The aïr that I've a-breath'd did sheäke

The draps o' rain upon the breäke,

brushwood

An' bear aloft the swingèn lark,

An' huffle roun' the elem's bark,

In boughy grove, an' woody park,

An' brought us down the dewy dells,

The high-wound zongs o' nightingeäles,

intricate

An' sounds o' flowèn water.

An' when the zun, wi' vi'ry rim,

'S a-zinkèn low, an' wearèn dim,

Here I, a-most too tired to stand,

Do leäve my work that's under hand

In pathless wood or oben land,

To rest 'ithin my thatchèn oves,

eaves

Wi' ruslèn win's in leafy groves,

An' sounds o' flowèn water. 
$\operatorname{sə:un}(\mathrm{d})$ ə wo:tər

ว:I ba:rn in tə:un o: no: mə:I de:n

ə lə:If bro:k hiər bisə:Id ðiəs le:n

not (h)wər pent æir də ro:l əlpy

In da:rknis dru: ðə wa:lbə:un(d) droy

ən nevər brin ðə guku:z zDy

nar swi(:)ts ə blosəmz in ðə hedz

or bendən $\mathrm{r} \Lambda \int$ or $\int \mathrm{i}$.nən $\mathrm{zed} 3$

or sə:un $(\mathrm{d}) \mathrm{z}$ ə flo:ən wo:tər

ði æIr ðət ə:IV əbri:ðd did jjek

ðə draps ə ræin əppn ðə brjek

ən beər əlpft ðə swijən la:rk

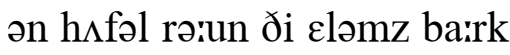

In bə:ui gro:v on wudi park

ən bro:t əs də:un ðə djuii delz

ðə hə:Iwə:und zpyz ə nə:itıngjelz

ən sə:un $(\mathrm{d}) \mathrm{z}$ ə flo:ən wo:tər

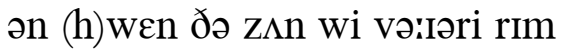

z əzinkən lo: on weərən dim

hiər ə:I aiməst tu: tə:Iərd tə $\operatorname{stan}(\mathrm{d})$

də liəv mə:I wə:rk ðəts $\Lambda$ ndər han(d)

In pe:Өlis wud or o:bən lan(d)

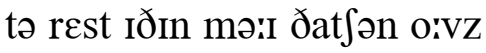

wi r $\Lambda$ slən winz in li:fi gro:vz

ən $\operatorname{sorun}(\mathrm{d}) \mathrm{z}$ ə flo:ən wo:tər 
WHEN zummer's burnèn het's a-shed beat's

Upon the droopèn grasses head,

A-drevèn under sheädy leaves

The workvo'k in their snow-white sleeves,

We then mid yearn to clim' the height,

Where thorns be white, above the vern; driving workfolk An' air do turn the zunsheen's might

To softer light too weak to burn-

On woodless downs we mid be free, But lowland trees be company.

Though downs mid show a wider view

O' green a-reachèn into blue

Than roads a-windèn in the glen, An' ringèn wi' the sounds o' men; The thissle's crown o' red an' blue

In Fall's cwold dew do wither brown, An' larks come down 'ithin the lew, shelter

As storms do brew, an' skies do frown-

An' though the down do let us free,

The lowland trees be company.

Where birds do zing, below the zun, In trees above the blue-smok'd tun, An' sheädes o' stems do overstratch The mossy path 'ithin the hatch;

If leaves be bright up over head, chimney-top shadows, tree-trunks wicket-gate

When Maÿ do shed its glitt'rèn light;

Or, in the blight o' Fall, do spread

A yollow bed avore our zight-

Whatever season it mid be, may

The trees be always company. 
tri:z bi: k^mpəni

(h)wen z^mərz bə:rnən hets $ə \int \varepsilon d$ әppn ðə dru:pən graisiz hed ədre:vən $\Lambda$ ndər Jjedi liivz ðə wə:rkvo:k In ðər sno:(h)wə:It sli:vz wi: ðعn mid jə:rn tə klim ðə hə:It

(h)wər ða:rnz bi: (h)wə:It əbムv ðə və:rn ən æIr də tə:rn ðə z $\Lambda$ nji:nz mə:It

to spftər lə:it tu: wi:k to bərrn pn (w)udlis də:unz wi: mid bi: fri: bət lo:lən(d) tri:z bi: kımpəni

ðo: də:unz mid fo: ə wə:Idər vju:

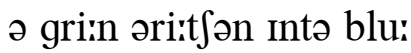

ðən ro:dz əwə:In(d)ən In ðə glen ən rijən wi ðə sə:un(d)z ə men ðə ðIsəlz krə:un ə red ən blu:

In fa:lz kuəld dju: də wiðər brə:un ən la:rks kım də:un ıðın ðə lu:

az sta:rmz də bru: ən skə:Iz də frə:un ən ðo: ðə dərun də let əs fri: ðə lo:lən(d) tri:z bi: kımpəni

(h)weər bə:rdz də zın bilo: ðə z^n In tri:z əb $\Lambda \mathrm{v}$ ठə blu:smo:kt t $\Lambda \mathrm{n}$ ən $\int j \varepsilon d z$ ə stemz du oivərstrat $\int$

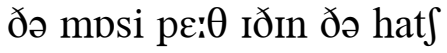
If li:vz bi: brə:It $\Lambda \mathrm{p}$ oivər hed

(h)wen mæi də $\int \varepsilon d$ its glitrən lə:It ar In ðə blə:it ə fail də spred ə jalər bed əvuər ə'uər zəit (h)wptevər si:zən It mId bi: ðə triiz bi: a:lwe:z kımpəni 
When dusky night do nearly hide

The path along the hedge's zide,

An' dailight's hwomely sounds be still

But sounds o' water at the mill;

except for

Then if noo feäce we long'd to greet

Could come to meet our lwonesome treäce

Or if noo peäce o' weary veet,

pace

However fleet, could reach its pleäce-

However lwonesome we mid be,

might

The trees would still be company. 
(h)wen d $\Lambda$ ski nə:It də niərli hə:Id

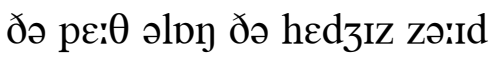
ən de:lə:Its huəmli sə:un(d)z bi: stıl bət sə:un(d)z ə wəitər ət ðə mil ðعn If nu: fjes wi: lpjd to griit

kud kım to mi:t ə'uər luənsəm trjes ar If nu: pjes ə wiəri vi:t hə:uevər fli:t kud ri:t its pljes hə:uعvər luənsəm wi: mid bi: ðə tri:z wud stıl bi: kımpəni 


\section{A PLEÄCE IN ZIGHT}

As I at work do look aroun'

Upon the groun' I have in view,

To yonder hills that still do rise

Avore the skies, wi' backs o' blue;

'Ithin the ridges that do vall

An' rise roun' Blackmwore lik' a wall,

'Tis yonder knap do teäke my zight

billock

Vrom dawn till night, the mwost ov all.

An' there, in Maÿ, 'ithin the lewth

shelter

O' boughs in blooth, be sheädy walks,

bloom

An' cowslips up in yollow beds

Do hang their heads on downy stalks;

An' if the weather should be feäir

When I've a holiday to speäre,

I'll teäke the chance o' gettèn drough

through

An hour or two wi' zome vo'k there.

folk

An' there I now can dimly zee

The elem-tree upon the mound,

An' there meäke out the high-bough'd grove

An' narrow drove by Redcliff ground;

An' there by trees a-risèn tall,

The glowèn zunlight now do vall,

Wi' shortest sheädes o' middle day,

shadows

Upon the gray wold house's wall.

old

An' I can zee avore the sky

A-risèn high the churches speer,

spire

Wi' bells that I do goo to swing,

An' like to ring, an' like to hear; 
ə pljes in zə:It

az ə:I ət wə:rk də luk ərə:un әppn ðə grə:un ə:I hav in vju: tə jandər hılz ðət stıl də rə:Iz әvuər ðə skə:Iz wi baks ə blu: ıðın ðə r $\Lambda$ dzIz ðat də va:l ən rə:Iz rə:un blakmuər lık ə wa:l tız jandər nap də tjek mə:I zə:It vrəm de:n tıl nə:It ðə muəst əv a:l

ən ðər In mæı ıðın ðə lu: $\theta$ ə bə:uz in blu: $\theta$ bi: $\int j \varepsilon d i$ we:ks ən kə:uslips $\Lambda$ in jalər bedz də haך ðər hedz pn də:uni ste:ks

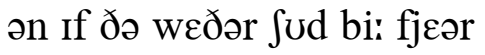
(h)wen ə:IV ə hplide: to spjeər

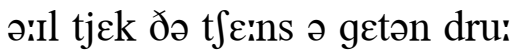

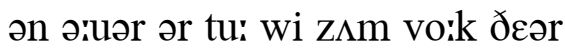

ən ðər ə:I nə:u kən dimli zi: ði عləmtri: əppn ðə mə:un(d) ən ðər mjદk ə:ut ðə hə:ıbə:ud gro:v ən narə(r) dro:v b(ə:)I redklıf grə:un(d) ən ðər b(ə:)i tri:z ərə:Izən tail ðə glo:ən z^nlə:ıt nə:u də va:l

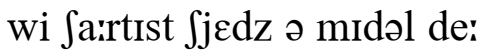
әppn ðə gre: (w)uəld hə:usız wa:l

ən ว:I kən zi: əvuər ðə skə:I

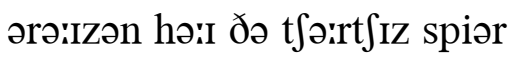
wi belz ðət ə:I də gu: tə swin on lə:Ik tə rin ən lə:ik tə hiər 
An' if I've luck upon my zide,

They bells shall sound bwoth loud an' wide,

A peal above they slopes o' gray,

Zome merry day wi' Jeäne a bride. 
ən If ə:IV $1 \Lambda \mathrm{k}$ əppn mə:I zə:Id

ðe: belz Jəl sə:un(d) buəð lə:ud ən wə:Id

ә pi:l əb $\Lambda$ v ðe: slo:ps ə gre:

zım meri de: wi dzjen ə brə:Id 
AT Easter, though the wind wer high,

We vound we had a zunny sky,

An' zoo wold Dobbin had to trudge

so old

His dousty road by knap an' brudge,

dusty, billock

An' jog, wi' hangèn vetterlocks

fetlocks

A-sheäkèn roun' his heavy hocks,

An' us, a lwoad not much too small,

A-ridèn out to Brookwell Hall;

An' there in doust vrom Dobbin's heels,

dust

An' green light-waggon's vower wheels,

four

Our merry laughs did loudly sound,

In rollèn winds athirt the ground;

across

While sheenèn-ribbons' color'd streäks

Did flutter roun' the maïdens' cheäks,

As they did zit, wi' smilèn lips,

A-reachèn out their vinger-tips

Toward zome teäkèn pleäce or zight

That they did shew us, left or right;

An' woonce, when Jimmy tried to pleäce

once

A kiss on cousin Polly's feäce,

She push'd his hat, wi' wicked leers,

Right off above his two red ears,

An' there he roll'd along the groun'

Wi' spreadèn brim an' rounded crown,

An' vound, at last, a cowpon's brim,

cowpond's

An' launch'd hizzelf, to teäke a zwim;

itself

An' there, as Jim did run to catch

His neäked noddle's bit o' thatch,

To zee his strainèns an' his strides,

We laugh'd enough to split our zides.

At Harwood Farm we pass'd the land

That father's father had in hand, 
gwæin to brukwel

at isstər ðо: ðə win(d) wər hə:I wi: və'un(d) wi: had a zıni skə:I ən zu: (w)uəld dpbin had to $\operatorname{tr} \Lambda \mathrm{d}_{3}$ (h)Iz də:usti ro:d b(ə:)I nap ən br $\Lambda d 3$ ən dzpg wi hayən vetərlpks ə)jekən rə:un (h)Iz hevi hoks ən $\Lambda$ s ə luəd not m $\Lambda \mathrm{t} \int$ tu: sma:l ərə:Idən ə:ut to brukwel ha:l ən ðər in dərust vrəm dpbinz hi:lz ən gri:n lə:itwagənz və:uər (h)willz ə:uər meri le:fs did lə:udli sə:un(d) In ro:lən win(d)z əðə:rt ðə grə:un(d) (h)wə:ıl fiinənrıbənz kılərd striəks did flıtər rə:un ðə mæidənz t fiəks əz ðe: did zit wi smə:ilən lips

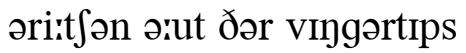

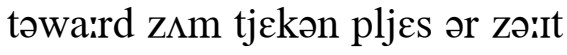
ðət ðe: did fo: əs left ər rə:it ən (w)uins (h)wen dzImi trə:Id to pljes ə kIs pn kızən ppliz fjes fi: puft (h)Iz hat wi wikıd liərz

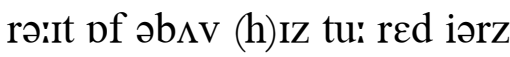
ən ðər ə ro:ld əlpy ðə grə:un wi spredən brim ən rə:undid krə:un ən vərun(d) ət leist ə kəiuppnz brim

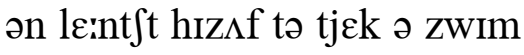
ən ठər əz dzIm did r $\Lambda$ n tə kat (h)Iz njekıd npdəlz bit ə ðat tə zi: (h)Iz stræInənz ən (h)Iz strə:Idz wi: le:ft in $\Lambda$ f to split ə:uər zə:Idz ət ha:rwod farrm wi: paist ðə lan(d) ðət fє:ðərz fe:ðər had in han(d) 
An' there, in oben light did spread,

The very groun's his cows did tread,

An' there above the stwonèn tun

fields

stone chimney

Avore the dazzlèn mornèn zun,

Wer still the rollèn smoke, the breath

A-breath'd vrom his wold house's he'th;

old, hearth

An' there did lie below the door,

The drashol' that his vootsteps wore;

threshold

But there his meäte an' he bwoth died,

Wi' hand in hand, an' zide by zide;

Between the seäme two peals a-rung,

Two Zundays, though they wer but young,

An' laid in sleep, their worksome hands,

At rest vrom tweil wi' house or lands.

toil

Then vower childern laid their heads

four

At night upon their little beds,

An' never rose ageän below

A mother's love, or father's ho:

care

Dree little maïdens, small in feäce,

three

An' woone small bwoy, the fourth in pleäce.

one

Zoo when their heedvul father died,

so

He call'd his brother to his zide,

To meäke en stand, in hiz own stead,

bim

His childern's guide, when he wer dead;

But still avore zix years brought round

The woodland goo-coo's zummer sound,

cuckoo's

He weästed all their little store,

An' hardship drove em out o' door,

To tweil till tweilsome life should end,

toil ... toilsome

'Ithout a single e'thly friend.

earthly

But soon wi' Harwood back behind,

An' out o' zight an' out o' mind,

We went a-rottlèn on, an' meäde

Our way along to Brookwell Sleäde; 
ən ðər In o:bən lə:It did spred ðə veri grə:unz (h)Iz kə:uz did tred ən ठər əb $\Lambda \mathrm{v}$ ठə stuənən $\mathrm{t} \Lambda \mathrm{n}$ əvuər ðə dazlən ma:rnən $\mathrm{z} \Lambda \mathrm{n}$ wər strl ðə ro:lən smo:k ðə bre $\theta$ əbri:ðd vrəm (h)Iz (w)uəld hə:usız he $\theta$ ən ðər did lə:I bilo: ðə duər ðə dra əəl ðət (h)IZ vutsteps wuər bət ðər (h)Iz mjet ən hi: buəð də:Id wi han(d) In han(d) ən zə:Id b(ə:)I zə:Id bitwi:n ðə sjem tu: pi:lz ər^y tu: zınde:z ðo: ðe: wər bət j $\wedge$ y ən led In sli:p ðər wərksəm han(d)z ət rest vrəm twəril wi hərus or lan(d)z

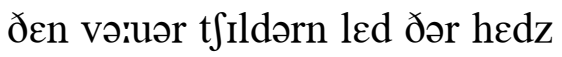
ət nə:It əppn ठər litəl bedz ən nevər ro:z əgjen bilo:

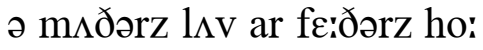
dri: litəl mæidənz smail in fjes

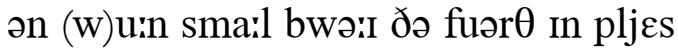
zu: (h)wen ðər hi:dvul fe:ðər də:Id hi: ka:ld (h)Iz brıðər tu (h)Iz zə:Id to mjek on $\operatorname{stan}(\mathrm{d})$ in (h)Iz o:n sted (h)Iz t f Ildərnz gə:Id (h)wen hi: wər ded bət stıl əvuər ziks jiərz bro:t rə:un(d) ðə (w)Udlən(d) guku:z z^mər sə:un(d) hi: wjestıd a:l ðər litəl stuər

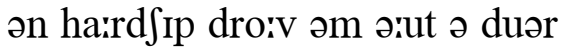

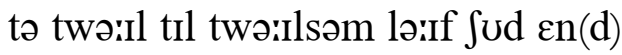
ıðə:ut ə singəl $\varepsilon \theta 1 i$ fren(d) bət su:n wi ha:rwud bak bihə:In(d) ən ə:ut ə zə:It ən ə:ut ə mə:In(d) wi: went ərotlən pn ən mjed ə:uər we: əlpy to brukwel sljed 
An' then we vound ourselves draw nigh

The Leädy's Tow'r that rose on high, An' seem'd a-comèn on to meet,

Wi' growèn height, wold Dobbin's veet. 


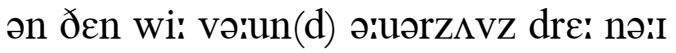

ðə ljediz tə:uər ðət ro:z pn hə:I

ən si(:)md əkımən pn to mi:t

wi gro:ən hə:It (w)uəld dpbinz viit 


\section{BROOKWELL}

WELL, I do zay 'tis wo'th woone's while

worth one's

To beät the doust a good six mile

dust

To zee the pleäce the squier plann'd

At Brookwell, now a-meäde by hand;

Wi' oben lawn, an' grove, an' pon',

pond

An' gravel-walks as cleän as bron;

bran

An' grass a'most so soft to tread

As velvet-pile o' silken thread;

An' mounds wi' mæsh, an' rocks wi' flow'rs,

moss

An' ivy-sheäded zummer bow'rs,

An' dribblèn water down below

The stwonen arch's lofty bow.

stone, arc

An' there do sound the watervall

Below a cavern's mæshy wall,

mossy

Where peäle-green light do struggle down

A leafy crevice at the crown.

An' there do gush the foamy bow

O' water, white as driven snow;

An' there, a zittèn all alwone,

A little maïd o' marble stwone

Do leän her little cheäk azide

Upon her lily han', an' bide

Bezide the vallèn stream to zee

falling

Her pitcher vill'd avore her knee.

An' then the brook, a-rollèn dark

Below a leänèn yew-tree's bark,

Wi' plaÿsome ripples that do run

A-flashèn to the western zun,

Do shoot, at last, wi' foamy shocks,

Athirt a ledge o' craggy rocks,

across

A-castèn in his heästy flight,

Upon the stwones a robe o' white; 
brukwel

wel ə:I də ze: tız wpð (w)u:nz (h)wə:ıl

tə biət ðə də:ust a gud siks mə:il

tə zi: ðə pljes ðə skwə:Iər pland

ət brukwel nə:u əmjed b(ə:) I han(d)

wi o:bən le:n ən gro:v ən ppn

ən gravəlwe:ks əz kliən əz bron

ən gra:s a:məst sə spft to tred

əZ velvitpəril a silkən dred

ən mə:un(d)z wi me: $\int$ ən roks wi flə'uərz

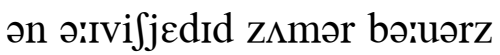

ən driblən wo:tər dərun bilo:

ðə stuənən a:rt $\int \mathrm{Iz}$ lpfti bo:

ən ðər də sə:un(d) ðə wə:tərva:l

bilo: ə kavərnz me: $\int \mathrm{i}$ wa:l

(h)wər pjelgriin ləitt də strıgəl də:un

ə li:fi krevis ət ðə krə'un

ən ðər də $\mathrm{g} \Lambda \int$ ðə fo:mi bo:

ə wəitər (h)wərit əz drivən sno:

ən ठər ə zitən ail əluən

ə litəl mæid ə ma:rbəl stuən

də liən (h)ər litəl t tjiək əzə:Id

əppn (h)ər lili han ən bə:Id

bIzə:Id ðə va:lən stri:m tə zi:

(h)ər pitfər vild əvuər (h)ər ni:

ən ðعn ðə bruk əro:lən da:rk

bilo: ə liənən ju:tri:z ba:rk

wi plæısəm ripəlz ðət də r $\Lambda \mathrm{n}$

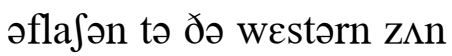

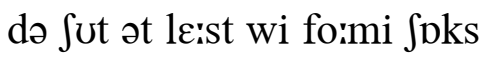

əðə:rt ə $1 \varepsilon \mathrm{d}_{3}$ ə kragi roks

əka:stən In (h)Iz hjesti flə:It

əppn ðə stuənz ə ro:b ə (h)wə:It 
An' then ageän do goo an' vall

Below a bridge's archèd wall,

Where vo'k agwaïn athirt do pass

folk, going across

Vow'r little bwoys a-cast in brass;

four

An' woone do hold an angler's wand, one

Wi' steady hand, above the pond;

An' woone, a-pweïntèn to the stream

pointing

His little vinger-tip, do seem

A-showèn to his playmeätes' eyes,

Where he do zee the vishes rise;

An' woone ageän, wi' smilèn lips,

Do put a vish his han' do clips

encircle

'Ithin a basket, loosely tied

About his shoulder at his zide:

An' after that the fourth do stand

A-holdèn back his pretty hand

Behind his little ear, to drow

throw

A stwone upon the stream below.

An' then the housèn, that be all

Sich pretty hwomes, vrom big to small,

A-lookèn south, do cluster round

A zunny ledge o' risèn ground,

Avore a wood, a-nestled warm,

In lewth ageän the northern storm,

shelter

Where smoke, a-wreathèn blue, do spread

Above the tuns o' dusky red,

An' window-peänes do glitter bright

Wi' burnèn streams o' zummer light,

Below the vine, a-train'd to hem

Their zides 'ithin his leafy stem,

An' rangle on, wi' flutt'rèn leaves,

stray

Below the houses' thatchen eaves.

An' drough a lawn a-spread avore

chimney-tops

The windows, an' the pworchèd door, 
ən ðعn əgjen də gu: ən va:l

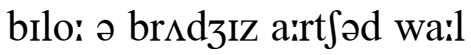

(h)wər vo:k əgwæIn əðə:rt də pa:s

və:uər litəl bwə:Iz əkaist in bra:s

ən (w)u:n də huəld ən anglərz wand

wi stedi han(d) əbムv ðə ppnd

ən (w)u:n əpwə:Intən tə ठə stri:m

(h)Iz litəl vingərtıp də si:m

əSo:ən tu (h)IZ plæImjets ə:IZ

(h)wər hi: də zi: ðə vIfız rə:Iz

ən (w)u:n əgjen wi smə:Ilən lips

də p $\Lambda \mathrm{t}$ ə vis (h)Iz han də klips

Iðın ə barskit lu:sli tə:Id

əbə:ut (h)Iz fo:ldər ət (h)Iz zə:Id

ən ع:tər ðat ðə fuər $\theta$ də $\operatorname{stan}(d)$

əho:ldən bak (h)Iz pərrti han(d)

bihə:In(d) (h)Iz litəl iər tə dro:

ə stuən əppn ðə stri:m bilo:

ən ðعn ðə hə:uzən ðət bi: a:l

sit $\int$ pə:rti huəmz vrəm big to sma:l

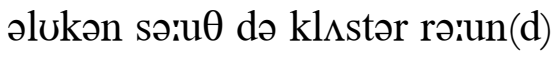

ə zムni led3 ə rə:Izən grə:un(d)

əvuər ə wud ənesəld wa:rm

In lu: $\theta$ әgjen ðə na:rðərn sta:rm

(h)wər smo:k əri:ðən blu: də spred

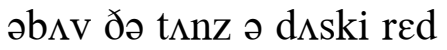

ən windərpjenz də glitər brə:it

wi bə:rnən stri:mz ə zムmər lə:It

bilo: ðə və:In ətræind tə hem

ðər zə:Idz Iðın (h)Iz li:fi stem

ən raygəl pn wi flıtrən li:vz

bilo: ðə hə:usız ðatfən i:vz

ən dru: ə le:n əspred əvuər

ðə windərz ən ðə puərtfId duər 
A path do wind 'ithin a hatch,

A-vastèn'd wi' a clickèn latch,

roof and chimney-top

An' there up over ruf an' tun,

Do stan' the smooth-wall'd church o' stwone,

Wi' carvèd windows, thin an' tall,

A-reachèn up the lofty wall;

An' battlements, a-stannèn round

standing

The tower, ninety veet vrom ground,

Vrom where a teäp'rèn speer do spring

tapering spire

So high's the mornèn lark do zing.

Zoo I do zay 'tis wo'th woone's while

so, worth one's

To beät the doust a good six mile,

To zee the pleäce the squier plann'd

At Brookwell, now a-meäde by hand. 
ə p $\varepsilon: \theta$ də wə:In(d) Iðın ə hat $\int$

əvaisənd wi ə klikən lat

ən ठər $\Lambda p$ orvər $r \Lambda f$ ən $t \wedge n$

də stan ðə smu:ðwa:ld t $\int ə$ :rt $\int$ ə stuən

wi ka:rvəd windərz ðIn ən ta:l

əri:tfən $\Lambda$ р ðə lpfti wa:l

ən batəlmənts əstanən rə:un(d)

ðə tə:uər nə:Inti vi:t vrəm grə:un(d)

vrəm (h)wər ə tjeprən spiər də sprin

sə hə:Iz ðə ma:rnən la:rk də zIn

zu: ə:I də ze: tIz wbð (w)u:nz (h)wə:Il

tə biət ðə də:ust ə gud siks mə:Il

tə zi: ðə pljes ðə skwə:ıər pland

ət brukwel nə:u əmjed b(ə:)I hand 
AH! good Meäster Gwillet, that you mid ha' know'd, may

Wer a-bred up at Coomb, an' went little abroad;

away from bome

An' if he got in among strangers, he velt

His poor heart in a twitter, an' ready to melt;

Or if, by ill luck, in his rambles, he met

Wi' zome maïdens a' titt'rèn, he burn'd wi' a het, beat

That shot all drough the lim's o'n, an' left a cwold zweat, through The poor little chap wer so shy, [his limbs

He wer ready to drap, an' to die.

But at last 'twer the lot o' the poor little man

To vall deeply in love, as the best ov us can;

An' 'twer noo easy task vor a shy man to tell

Sich a dazzlèn feäir maïd that he loved her so well;

An' woone day when he met her, his knees nearly smote one

Woone another, an' then wi' a struggle he bro't brought

A vew words to his tongue, wi' some mwore in his droat. throat

But she, 'ithout doubt, could soon vind

Vrom two words that come out, zix behind.

Zoo at langth, when he vound her so smilèn an' kind, so

Why he wrote her zome laïns, vor to tell her his mind, lines

Though 'twer then a hard task vor a man that wer shy, To be married in church, wi' a crowd stannèn by. standing

But he twold her woone day, "I have housen an' lands, We could marry by licence, if you don't like banns," An' he cover'd his eyes up wi' woone ov his han's,

Vor his head seem'd to zwim as he spoke, An' the airr look'd so dim as a smoke. 


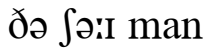

a: gud mjaistər gwilət ðat ju: mid hə no:d wər əbred $\Lambda \mathrm{p}$ ət ku:m ən went litəl əbro:d ən If ə gpt In əmpy strandzərz ə velt (h)Iz pu(:)ər hairt In ə twitər ən redi tə melt

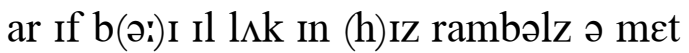
wi z^m mæidənz ətitrən ə bə:rnd wi ə het ðət $\int \mathrm{pt}$ a:l dru: ðə limz o:n ən left ə kuəld zwet

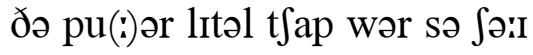
hi: wər redi tə drap ən to də:I

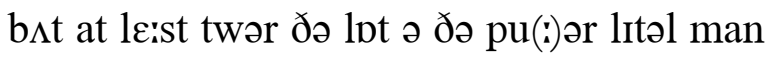
tə va:l di:pli in $1 \Lambda \mathrm{v}$ az ðə best əv əs kan

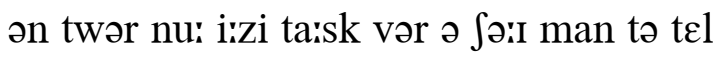
sit ə dazlən fjeər mæid ðat ə $1 \Lambda \mathrm{vd}$ (h)ər sə wel ən (w)u:n de: (h)wen ə met hər (h)rz ni:z niərli smo:t (w)u:n ən^ðər ən ðعn wi ə strıgəl hi: bro:t a vju: wə:rdz tu (h)Iz tıy wi səm muər In (h)Iz dro:t bət $\int i$ i: Iðə:ut də:ut kud suin və:In(d) vrəm tu: wə:rdz ðət kım ərut zIks bihə:ın(d)

zu: ət lay $\theta$ (h)wen ə və:un(d) (h)ər sə smə:Ilən ən kə:In(d) (h)wə:I ə ro:t (h)ər z^m lə:Inz vər to tel (h)ər (h)Iz mə:In(d) ðо: twər ðعn ə ha:rd taisk vər ə man ðət wər Sə:I to bi: marid in t $\int$ ərt $\int$ wi ə krə:ud stanən bə:I bət hi: tuəld (h)ər (w)uin de: ə:I hav hə:uzən ən lanz wi: kud mari b(ə:)I lə:Isəns if jə do:nt lə:tk banz ən ə k $\Lambda$ vərd (h)Iz ə:Iz $\Lambda$ p wi (w)uin əv (h)Iz hanz $\operatorname{var}(\mathrm{h}) \mathrm{Iz}$ hed si(:)md to zWIm əz hi: spo:k ən ði æır lukt sə dım əz ə smo:k 
Well! he vound a good naïghbour to goo in his pleäce

Vor to buy the goold ring, vor he hadden the feäce.

An' when he went up vor to put in the banns,

He did sheäke in his lags, an' did sheäke in his han's.

Then they ax'd vor her neäme, an' her parish or town,

asked

An' he gi'ed em a leaf wi' her neäme a-wrote down;

gave

Vor he coulden ha' twold em outright, vor a poun',

Vor his tongue wer so weak an' so loose,

When he wanted to speak 'twer noo use.

Zoo they went to be married, an' when they got there

All the vo'k wer a-gather'd as if 'twer a feäir,

folk

An' he thought, though his pleäce mid be pleazèn to zome,

might

He could all but ha' wish'd that he hadden a-come.

The bride wer a-smilèn as fresh as a rwose,

An' when he come wi' her, an' show'd his poor nose,

All the little bwoys shouted, an' cried "There he goes,"

"There he goes." Oh! vor his peärt he velt

As if the poor heart o'n would melt.

of him

An' when they stood up by the chancel together,

Oh! a man mid ha' knock'd en right down wi' a veather,

bim

He did veel zoo asheäm'd that he thought he would rather

so

He wërden the bridegroom, but only the father.

But, though 'tis so funny to zee en so shy,

Yeet his mind is so lowly, his aïms be so high,

That to do a meän deed, or to tell woone a lie,

one

You'd vind that he'd shun mwore by half,

Than to stan' vor vo'ks fun, or their laugh. 
wel ə və:un(d) ə gud nærbər tə gu: In (h)Iz pljes vər tə bə:I ðə guild rin vər hi: hadən ठə fjes ən (h)wen ə went $\Lambda$ p var tə p $\Lambda$ t In ðə banz ə did Sjek in (h)Iz lagz ən did Sjek In (h)Iz hanz ðعn ðe: a:kst vər (h)ər njem ən (h)ər parI $\int$ ar tə:un ən ə gi:d əm ə li:f wi (h)ər njem əro:t dəiun var hi: kudən hə tuəld əm ərutrə:It vər ə pərun $\operatorname{var}(\mathrm{h}) \mathrm{Iz}$ t $\Lambda$ y wər sə wik ən sə luis (h)wen ə wpntıd tə spi:k twər nu: juis

zu: ðe: went to bi: marid ən (h)wen ðe: gpt ðعər a:l ðə vo:k wər əgaðərd az If twər ə fjeər

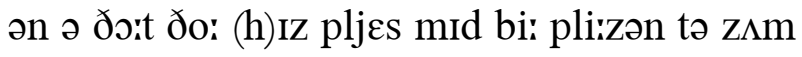
hi: kud a:l bət hə wift ðət hi: hadən əkım ðə brə:Id wər əsmə:Ilən əz fre $\int$ əz ə ruəz ən (h)wen ə kım wi (h)ər ən Jo:d (h)Iz pu(:)ər no:z a:l ðə litəl bwə:Iz Sərutıd ən krə:Id ठər ə go:z ðər ə go:z o: var (h)Iz pjairt hi: velt əZ If ðə pu(:)ər harrt o:n wud melt

ən (h)wen ðe: stud $\Lambda$ p b(ə:)I ðə t fainsəl təgeðər o: ə man mid hə nokt ən rə:It də:un wi ə veðər

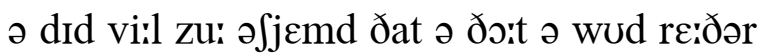
hi: wə:rdən ðə brə:Idgru:m bət o:nli ðə fє:ðər

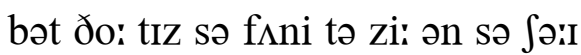
(j)i:t (h)Iz mə:In(d) IZ sə lo:li (h)Iz æImz bi: sə hə:I ðat tə du: ə miən di:d ar to tel (w)uin ə lə:I ju:d və:In(d) ðat hi:d $\int \Lambda \mathrm{n}$ muər b(ə:) I he:f ðən tə stan var vo:ks f $\wedge$ n ar ðər le:f 
THERE Liddy zot bezide her cow, sat

Upon her lowly seat, $\mathrm{O}$;

A hood did overhang her brow,

Her pail wer at her veet, $\mathrm{O}$;

An' she wer kind, an' she wer feäir,

An' she wer young, an' free o' ceäre;

Vew winters had a-blow'd her heäir,

Bezide the Winter's Willow.

She idden woone a-rear'd in town,

Where many a gaÿer lass, $\mathrm{O}$,

Do trip a-smilèn up an' down,

So peäle wi' smoke an' gas, $\mathrm{O}$;

But here, in vields o' greäzèn herds,

Her väice ha' mingled sweetest words

Wi' evenèn cheärms o' busy birds, noises

Bezide the Winter's Willow.

An' when, at last, wi' beätèn breast,

I knock'd avore her door, $\mathrm{O}$,

She ax'd me in to teäke the best

asked

O' pleäces on the vloor, $\mathrm{O}$;

An' smilèn feäir avore my zight,

She blush'd bezide the yollow light

O' bleäzèn brands, while winds o' night

Do sheäke the Winter's Willow.

An' if there's readship in her smile,

trustworthiness

She don't begrudge to speäre, $\mathrm{O}$,

To zomebody, a little while,

The empty woaken chair, $\mathrm{O}$;

oak 
ðə wintərz wilər

ðər lidi zat bizə:Id (h)ər kə:u

əppn (h)ər lo:li si:t o:

ə hud did sivərhay (h)ər brə:u

(h)ər pæil wər ət (h)ər vi:t o:

ən Ji: wər kə:In(d) ən Ji: wər fjeər

ən $\int \mathrm{i} i \mathrm{w}$ wor $\mathrm{j} \Lambda \mathrm{y}$ ən fri: ə kjeər

vju: wintərz had əblo:d (h)ər hjeər

bizə:Id ðə wintərz wilər

Si: Idən (w)u:n əreərd in tə:un

(h)wər meni ə gæıər las o:

də trip əsmə:ilən $\Lambda p$ ən də:un

sə pjel wi smo:k ən gas o:

bət hiər in vill(d)z ə grjezən hə:rdz

(h)ər væIs hə mingəld swi(:)tist wərrdz

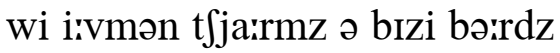

bizə:Id ðə wintərz wilər

ən (h)wen ət leist wi biətən brest

ə:I npkt əvuər (h)ər duər o:

fii a:kst mi: in to tjek ðə best

ə pljesiz pn ðə vluər o:

ən smə:Ilən fjeər əvuər mə:I zə:It

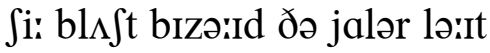

ə bljezən bran(d)z (h)wə:Il win(d)z ə nə:It

də Sjek ðə wintərz wilər

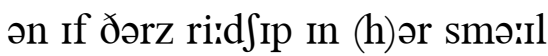

Si: do:nt bigr $\Lambda d_{3}$ to spjeər o:

tə zムmbpdi ə litəl (h)wə:Il

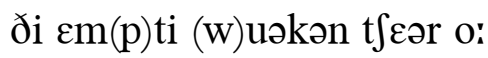


An' if I've luck upon my zide,

Why, I do think she'll be my bride

Avore the leaves ha' twice a-died

Upon the Winter's Willow.

Above the coach-wheels' rollèn rims

She never rose to ride, $\mathrm{O}$,

Though she do zet her comely lim's

Above the mare's white zide, $\mathrm{O}$;

But don't become too proud to stoop

An' scrub her milkèn pail's white hoop,

Or zit a-milkèn where do droop

The wet-stemm'd Winter's Willow.

-trunked

An' I've a cow or two in leäze,

meadow

Along the river-zide, $\mathrm{O}$,

An' pails to zet avore her knees,

At dawn an' evenèn-tide, $\mathrm{O}$;

An' there she still mid zit, an' look

may

Athirt upon the woody nook

across

Where vu'st I zeed her by the brook

first, saw

Bezide the Winter's Willow.

Zoo, who would heed the treeless down,

A-beät by all the storms, $\mathrm{O}$,

Or who would heed the busy town,

Where vo'k do goo in zwarms, $\mathrm{O}$;

If he wer in my house below

The elems, where the vier did glow

fire

In Liddy's feäce, though winds did blow Ageän the Winter's Willow. 
ən If ə:Iv $1 \Lambda \mathrm{k}$ əppn mə:I zə:Id

(h)wə:I ə:I də ðınk fi:l bi: mə:I brə:Id əvuər ðə li:vz hə twər:s ədə:Id əppn ðə wintərz wilər

əb $\Lambda$ v ðə ko:t (h)wi:lz ro:lən rimz

fi: nevər ro:z tə rə:Id o:

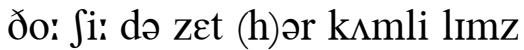

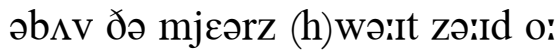
bət do:nt bikım tu: prəud tə stu:p ən skrıb (h)ər milkən pæilz (h)wə:It hu:p ar zit əmilkən (h)wər də dru:p

ðə wetstemd wintərz wilər

วn ว:IV ə kə:u ər tu: in liəz əlpy ðə rivərzə:Id o: ən pæilz tə zet əvuər (h)ər ni:z ət de:n ən iivməntə:Id o: ən ठər Ji: stıl mid zit ən luk əðə:rt əppn ðə wudi nuk (h)wər vıst ə:I zi:d (h)ər b(ə:)I ðə bruk bizə:Id ðə wintərz wilər

zu: hu: wod hi:d ðə tri:lis də:un əbiət b(ə:)I a:l ठə sta:rmz o: ar hu: wud hi:d ðə bizi tə:un

(h)wər vo:k də gu: in zwa:rmz o:

If hi: wər in mə:I hə:us bilo: ði عləmz (h)wər ðə və:Iər did glo: In lidiz fjes ðo: win(d)z did blo: əgjen ðə wintərz wilər 
AYE, aye, vull rathe the zun mus' rise early

To meäke us tired o' zunny skies,

A-sheenèn on the whole day drough, shining, through

From mornèn's dawn till evenèn's dew.

When trees be brown an meäds be green, An' skies be blue, an' streams do sheen, shine An' thin-edg'd clouds be snowy white Above the bluest hills in zight;

But I can let the daylight goo,

When I've a-met wi'-I know who.

In Spring I met her by a bed

O' laurels higher than her head;

The while a rwose hung white between

Her blushes an' the laurel's green;

An' then in Fall, I went along

The row of elems in the drong, lane

An' heärd her zing bezide the cows,

By yollow leaves o' meäple boughs;

But Fall or Spring is feäir to view

When day do bring me-I know who.

An' when, wi' wint'r a-comèn roun', The purple he'th's a-feädèn brown, beath's An' hangèn vern's a-sheäkèn dead, fern's

Bezide the hill's besheäded head:

An' black-wing'd rooks do glitter bright

Above my head, in peäler light;

Then though the birds do still the glee

That sounded in the zummer tree,

My heart is light the winter drough,

In me'th at night, wi'-I know who. 
ว:I no: hu:

æI æI vul rjeð ðə Zムn məs rə:IZ to mjek əs tə:Iərd ə zıni skə:Iz

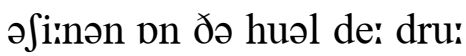
vrəm ma:rnənz de:n tıl i:vmənz dju: (h)wen tri:z bi: brə:un ən miədz bi: grimn ən skə:Iz bi: blu: ən stri:mz də Ji:n ən ðınedzd klə;udz bi: sno:i (h)wə:It

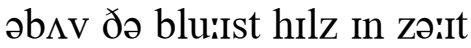
bət ə:I kən let ðə de:lə:it gu: (h)wen ə:IV əmet wi ə:I no: hu:

In sprin ə:I met (h)ər b(ə:)I ə bed ə lprəlz hə:Iər ઇən (h)ər hed ðə (h)wə:Il ə ruəz h^y (h)wə:It bitwi:n

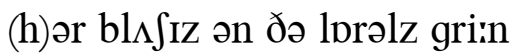
ən ðعn in fa:l ə:I went əlpy ðə ro: əv عləmz In ðə droy ən hiərd (h)ər zIy bizə:Id ðə kə:uz b(ə:)I jalər li:vz ə mjepəl bə:uz bət fa:l ar sprin iz fjeər to vju: (h)wen de: do brin mi: əiı no: hu:

ən (h)wen wi wintr əkımən rə:un ðə pə:rpəl he $\theta$ s əfjedən brə:un ən hayən və:rnz əरjekən ded

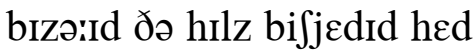
ən blakwind ruks də glitər brə:it

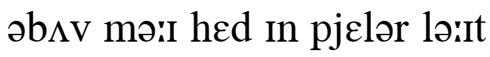
ðعn ðо: ðə bə:rdz də stıl ðə gli: ðət sə:un(d)Id In ðə z^mər tri: mə:I ha:rt Iz lə:It ðə wintər dru: In $m \varepsilon \theta$ ət nə:It wi ə:I no: hu: 
JESSIE LEE

ABOve the timber's bendèn sh'ouds,

The western wind did softly blow;

An' up avore the knap, the clouds

billock

Did ride as white as driven snow.

Vrom west to east the clouds did zwim

Wi' wind that plied the elem's lim';

Vrom west to east the stream did glide,

A-sheenèn wide, wi’ windèn brim.

shining

How feäir, I thought, avore the sky

The slowly-zwimmèn clouds do look;

How soft the win's a-streamèn by;

How bright do roll the weävy brook:

When there, a-passèn on my right,

A-walkèn slow, an' treadèn light,

Young Jessie Lee come by, an' there

Took all my ceäre, an' all my zight.

Vor lovely wer the looks her feäce

Held up avore the western sky:

An' comely wer the steps her peäce

pace

Did meäke a-walkèn slowly by:

But I went east, wi' beäten breast,

Wi' wind, an' cloud, an' brook, vor rest,

Wi' rest a-lost, vor Jessie gone

So lovely on, toward the west.

Blow on, $\mathrm{O}$ winds, athirt the hill;

across

Zwim on, O clouds; O waters vall,

Down mæshy rocks, vrom mill to mill;

mossy

I now can overlook ye all. 
dzesi li:

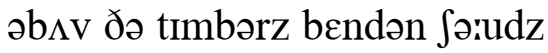

ðə westərn win(d) did spf(t)li blo:

ən $\Lambda$ p әvuər ðə nap ðə klə:udz

did rə:Id əz (h)wə:It əz drIvən sno:

vrəm west tu i:st ðə klərudz did zwim

wi win(d) ðət plə:Id ði عləmz lim

vrəm west tu iist ðə stri:m did glə:Id

ə)i:nən wə:Id wi wə:In(d)ən brim

hə:u fjeər ə:I ðっ:t əvuər ðə skə:I

ðə slo:lizwimən klə:udz də luk

hə:u spft ðə winz əstri:mən bə:I

hə:u brə:It də ro:l ðə wjevi bruk

(h)wen ðər əpa:sən pn mə:I rə:It

əwe:kən slo: ən tredən lə:It

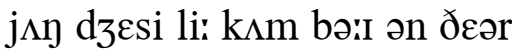

tuk a:l mə:I kjeər ən a:l mə:I zə:It

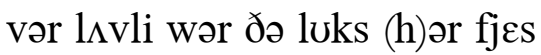

held $\Lambda$ p әvuər ðə westərn skə:I

ən k^mli wər ðə steps (h)ər pjes

did mjek əwع:kən slo:li bə:I

bət ə:I went iist wi biətən brest

wi win(d) ən kləuud ən bruk vər rest

wi rest əlpst vər dzesi gon

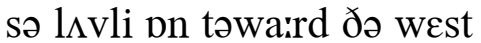

blo: pn o: win(d)z əðə:rt ðə hıl

zwim pn o: klə:udz o: wo:tərz va:l

də:un me: $\int \mathrm{i}$ roks vrəm mil to mil

ə:I nə:u kən orvərluk i: a:l 
But roll, $\mathrm{O}$ zun, an' bring to me

My day, if such a day there be,

When zome dear path to my abode

Shall be the road o' Jessie Lee. 
bət ro:l o: zAn on brin to mi:

mə:I de: If sit $\int$ ə de: ðər bi:

(h)wen z^m diər pe: $\theta$ tə mə:I əbo:d

ऽəl bi: ðə ro:d ə dzesi li: 
As evenèn aïr, in green-treed Spring,

Do sheäke the new-sprung pa'sley bed, An' wither'd ash-tree keys do swing An' vall a-flutt'rèn roun' our head:

There, while the birds do zing their zong

In bushes down the ash-tree drong, lane

Come Jessie Lee, vor sweet's the pleäce

Your vaïce an' feäce can meäke vor me.

Below the buddèn ashes' height

We there can linger in the lew, shelter

While boughs, a-gilded by the light,

Do sheen avore the sky o' blue:

But there by zettèn zun, or moon

A-risèn, time wull vlee too soon

Wi' Jessie Lee, vor sweet's the pleäce

Her vaïce an' feäce can meäke vor me.

Down where the darksome brook do flow,

Below the bridge's archèd wall,

Wi' alders dark, a-leanèn low,

Above the gloomy watervall;

There I've a-led ye hwome at night,

Wi' noo feäce else 'ithin my zight

But yours so feäir, an' sweet's the pleäce

Your vaïce an' feäce ha' meäde me there.

An' oh! when other years do come, An' zettèn zuns, wi' yollow gleäre,

Drough western window-peänes, at hwome, through

Do light upon my evenèn chair: 
tru: $1 \Lambda \mathrm{v}$

az i:vmən æIr In grintriid sprin də Sjek ðə nju:spr $\wedge$ p pa:sli bed ən wiðərd aftri: ke:z də swin ən va:l əfl $\Lambda$ trən rə:un ə:uər hed ðər (h)wə:Il ðə bə:rdz də zin ðər zpy

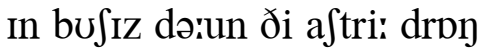
kım dzesi li: var swi(:)ts ðə pljes ju(:)ər væIs ən fjes kən mjek vər mi:

bılo: ðə bıdən a alz hə:It wi: ðər kən lingər in ðə lu: (h)wə:Il bə:uz əgildıd b(ə:)I ðə lə:It də Si:n əvuər ðə skə:I ə blu: bət ðər b(ə:)I zetən zムn ər mu:n วrə:Izən tə:Im wul vli: tu: su:n wi dzesi li: var swi(:)ts ðə pljes (h)ər væIs ən fjes kən mjek vər mi:

də:un (h)wər ðə da:rksəm bruk də flo:

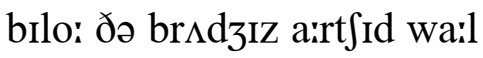
wi a:ldərz da:rk əliənən lo:

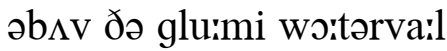
ðər ə:IV əlદd i: huəm ət nə:It wi nu: fjes عls Iðın mə:I zə:It bət ju(:)ərz sə fjeər ən swi(:)ts ðə pljes ju(:)ər væIs ən fjes hə mjed mi: ðعər

ən o: (h)wعn $\Lambda$ ðr jiərz də kım ən zetən z^nz wi jalər gljeər dru: westərn windərpjenz ot huəm də lə:It əppn mə:I iivmən $\mathrm{t} \int \varepsilon \partial \mathrm{r}$ 
While day do weäne, an' dew do vall,

Be wi' me then, or else in call,

As time do vlee, vor sweet's the pleäce

Your vaïce an' feäce do meäke vor me.

Ah! you do smile, a-thinkèn light

O' my true words, but never mind;

Smile on, smile on, but still your flight

Would leäve me little jaÿ behind:

But let me not be zoo a-tried

Wi' you a-lost where I do bide,

O Jessie Lee, in any pleäce

Your vaïce an' feäce ha' blest vor me.

I'm sure that when a soul's a-brought

To this our life ov air an' land,

Woone mwore's a-mark'd in God's good thought,

To help, wi' love, his heart an' hand.

An' oh! if there should be in store

An angel here vor my poor door,

'Tis Jessie Lee, vor sweet's the pleäce

Her vaïce an' feäce can meäke vor me. 
(h)wə:Il de: də wjen ən dju: də va:l bi: wi mi: ðعn ar els in ka:l az tə:Im də vli: var swi(:)ts ðə pljes ju(:)ər væIs ən fjes də mjєk vər mi:

a: ju: də smə:Il əðınkən lə:ıt ə mə:I tru: wə:rdz bət nevər mə:In(d) smə:Il pn smə:Il pn bət strl ju(:)ər flə:it wud liəv mi: litəl dzæi bihə:In(d) bət let mi: not bi: zu: ətrəid wi ju: əlpst (h)wər ə:I də bə:Id o: dzesi li: in eni pljes ju(:)ər væIs ən fjes hə blest vər mi: ə:Im $\int \mathrm{u}(:) \partial r$ ðət (h)wen ə so:lz əbro:t tə ठIs ə:uər lə:If əv æIr ən lan(d) (w)u:n muərz əma:rkt in gpdz gud ðo:t to help wi $1 \Lambda \mathrm{v}$ (h)rz ha:rt ən han(d) ən o: If ðər Jud bi: In stuər ən andzəl hiər vər mə:I pu(:)ər duər tız dzesi li: var swi(:)ts ðə pljes (h)ər væIs ən fjes kən mjєk vər mi: 
'TWER where the zun did warm the lewth, shelter An' win' did whiver in the sheäde, quiver

The sweet-aïr'd beäns were out in blooth, bloom

Down there 'ithin the elem gleäde;

A yollow-banded bee did come, An' softly-pitch, wi' hushèn hum, Upon a beän, an' there did sip, Upon a swaÿèn blossom's lip: An' there cried he, “Aye, I can zee, This blossom's all a-zent vor me.”

A-jilted up an' down, astride

Upon a lofty ho'se a-trot, horse

The meäster then come by wi' pride,

To zee the beäns that he'd a-got;

An' as he zot upon his ho'se, sat

The ho'se ageän did snort an' toss

His high-ear'd head, an' at the zight

Ov all the blossom, black an' white:

"Ah! ah!" thought he, the seäme's the bee,

"Theäse beäns be all a-zent vor me."

these

Zoo let the worold's riches breed so

A strife o' claïms, wi' weak and strong,

Vor now what cause have I to heed

Who's in the right, or in the wrong;

Since there do come drough yonder hatch, through, wicket-gate An' bloom below the house's thatch,

The best o' maïdens, an' do own

That she is mine, an' mine alwone:

Zoo I can zee that love do gi'e give

The best ov all good gifts to me. 
ðə biən vi:l(d)

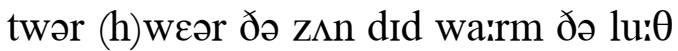

ən win did (h)wivər in ðə $\int j \varepsilon d$

ðə swi(:)tæird biənz wər ə:ut in blu: $\theta$

də'un ðər Iðın ði عləm gljed

ə jalərbandid bi: did kım

ən spf(t)li pit wi $h \wedge \int \partial n h \wedge m$

әppn ə biən ən ðər did sip

әppn ə swæiən blpsəmz lip

ən ðər krə:Id hi: æı ə:I kən zi:

ðıs blpsəmz a:l əzent vər mi:

ədzIltid $\Lambda p$ ən dərun əstrrə:Id əppn ə lpfti hps ətrpt

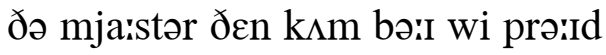

tə zi: ðə biənz ठət hi:d əgpt

ən az hi: zat əppn (h)Iz hps

ðə hps əgjen did sna:rt ən tps

(h)Iz hə:Iiərd hed ən at ðə zə:It

əv a:l ðə blpsəm blak ən (h)wə:It

a: a: ðっ: hi: ðə sjemz ðə bi:

ðiəz biənz bi: a:l əzent vər mi:

zu: let ðə wə:rdəlz rit $\int \mathrm{Iz}$ bri:d

ə strə:If ə klæImz wi wi:k ən(d) strpy

vər nə:u (h)wpt kje:z həv ə:i tə hi:d

hu:z In ठə rə:It ar In ठə roy

sins ðər də kım dru: jandər hat

ən blu:m bilo: ðə hə:usız ðat

ðə best ə mæIdənz ən du o:n

ðət $\int i:$ IZ mə:In ən mə:In əluən

zu: ə:I kən zi: ðət $1 \Lambda \mathrm{v}$ də gi:

ðə best əv a:l gud gifts tə mi: 
Vor whose be all the crops an' land

A-won an' lost, an' bought, an zwold

Or whose, a-roll'd vrom hand to hand,

The highest money that's a-twold?

counted

Vrom man to man a passèn on,

'Tis here to-day, to-morrow gone.

But there's a blessèn high above

It all—a soul o' stedvast love:

Zoo let it vlee, if God do gi'e

so, fly, give

Sweet Jessie vor a gift to me. 
vər hu:z bi: a:l ðə krops ən lan(d)

əw $\Lambda$ n ən lpst ən bə:t ən zuəld

ar hu:z əro:ld vrom han(d) to han(d)

ðə hə:IIst mıni ðəts ətuəld

vrəm man to man ə paisən pn

tIz hiər təde: təmarə(r) gon

bət ðərz ə blesən hə:I əb $\Lambda \mathrm{V}$

It a:l ə so:l a stedvaist $1 \Lambda \mathrm{v}$

zu: let It vli: If god də gi:

swi(:)t dzesi vər ə gift to mi: 
AYE, vull my heart's blood now do roll,

An' gaÿ do rise my happy soul,

An' well they mid, vor here our veet

Avore woone vier ageän do meet;

one fire

Vor you've avoun' my feäce, to greet

Wi' welcome words my startlèn ear.

startled

An' who be you, but John o' Weer,

An' I, but William Wellburn.

Here, light a candle up, to shed

Mwore light upon a wold friend's head,

An' show the smile, his feäce woonce mwore

once

Ha' brought us vrom another shore.

An' I'll heave on a brand avore

The vier back, to meäke good cheer,

O' roarèn fleämes, vor John o' Weer

To chat wi' William Wellburn.

Aye, aye, it mid be true that zome,

When they do wander out vrom hwome,

Do leäve their nearest friends behind,

Bwoth out o' zight, an' out o' mind;

But John an' I ha' ties to bind

Our souls together, vur or near,

For, who is he but John o' Weer,

An' I, but William Wellburn.

Look, there he is, with twinklèn eyes,

An' elbows down upon his thighs,

A-chucklèn low, wi' merry grin. 
(w)uəld fren(d)z əmet

æI vul mə:I ha:rts blıd nə:u də ro:l ən gæi də rə:Iz mə:I hapi so:l ən wel ðe: mId vər hiər ə'uər vi:t əvuər (w)u:n və:ıər əgjen də mi:t vər ju:v əvərun mə:I fjes to gri:t wi welkəm wə:rdz mə:I sta:rtlən iər ən hu: bi: ju: bət dzan ə wiər ən ə:I bət wiləm welbə:rn

hiər lə:It ə kandəl $\Lambda p$ tə $\int \varepsilon d$ muər lə:It əppn ə (w) uəld fren(d)z hed ən אo: ðə smə:Il (h)Iz fjes (w)u:ns muər hə bro:t əs vrəm ən^ðər Juər ən ə:Il hi:v pn ə bran(d) əvuər ðə və:ıər bak tə mjek gud tfiər ə ruərən fljemz vər dzan ə wiər to tfat wi wiləm welbərrn

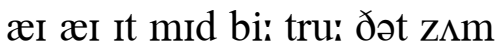
(h)wen ðe: də wondər ə:ut vrəm huəm də liəv ðər niərıst fren (d)z bihə:In(d) buəð ə:ut ə zə:It ən ə:ut ə mə:In(d) bət dzan ən ə:I hə tə:Iz tə bə:In(d) ə:uər so:lz təgદðər və:r ar niər var hu: iz hi: bət dzan ə wior ən ə:I bət wiləm welbə:rn

luk ðər hi: Iz wi(ð) twıjklən ə:Iz ən عlbo:z də'un əppn (h)Iz Өə:Iz ot $\int \Lambda$ klən lo: wi meri grm 
Though time ha' roughen'd up his chin,

'Tis still the seäme true soul 'ithin,

As woonce I know'd, when year by year, once

Thik very chap, thik John o' Weer, that

Did plaÿ wi' William Wellburn.

Come, John, come; don't be dead-alive

Here, reach us out your clust'r o' vive.

half-dead

Oh! you be happy. Ees, but that cluster of five (fingers) yes

Woon't do till you can laugh an' chat.

Don't blinky, lik' a purrèn cat,

But leäp an' laugh, an' let vo'k hear folk

What's happen'd, min, that John o' Weer mate

Ha' met wi' William Wellburn.

Vor zome, wi' selfishness too strong

Vor love, do do each other wrong;

An' zome do wrangle an' divide

In hets ov anger, bred o' pride;

beats

But who do think that time or tide

Can breed ill-will in friends so dear,

As William wer to John o' Weer,

An' John to William Wellburn?

If other vo'ks do gleen to zee

How lovèn an' how glad we be,

What, then, poor souls, they had but vew

Sich happy days, so long agoo,

As they that I've a-spent wi' you;

But they'd hold woone another dear,

If woone o' them wer John o' Weer, An' tother William Wellburn. 
ðo: tə:Im hə $\mathrm{r} \Lambda$ fənd $\Lambda \mathrm{p}(\mathrm{h}) \mathrm{IZ} \mathrm{t} \int \mathrm{In}$ tIz stıl ðə sjem tru: so:l ıðın əz (w)u:ns ə:I no:d (h)wen jiər b(ə:)I jiər ðık veri t $\int a p$ ðIk dzan ə wiər did plæı wi wiləm welbə:rn

kım dzan kım do:nt bi: dedələ:IV hiər ritt əs ərut jər klıstr ə və:IV o: ju: bi: hapi iss bət dat wu(:)nt du: til jə kən le:f on t tat do:nt blınki lik ə pərrən kat bət liəp ən le:f ən let vo:k hiər (h)wpts hapənd min ðət dzan ə wiər hə met wi wiləm welbə:rn

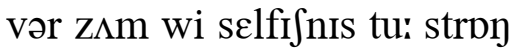
vər $1 \Lambda \mathrm{v}$ də du: iit $\Lambda$ ðər ron ən z $\Lambda \mathrm{m}$ də raygəl ən divə:Id In hets əv angər bred ə prəiId bət hu: də ठıjk ðət tə:Im ar tə:Id kən bri:d Ilwil in fren(d)z sə diər oz wiləm wər to dzan $ə$ wiər ən dzan tə wiləm welbə:rn

If $\Lambda$ ðr vo:ks də gliin tə zi:

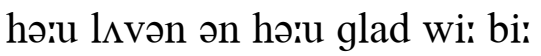
(h)wpt ðen pu(:)ər so:lz ðe: had bət vju: sit $\int$ hapi de:z sə lon əgu: əz ðе: ðət ə:IV əspent wi ju: bət ðe:d huəld (w)u:n ən^ðər diər If (w)uin ə ðعm wər dzan ə wiər ən tムðər wiləm welbə:rn 
FIFEHEAD

'TwER where my fondest thoughts do light,

At Fifehead, while we spent the night;

The millwheel's restèn rim wer dry,

An' houn's held up their evenèn cry;

An' lofty, drough the midnight sky,

Above the vo'k, wi' heavy heads, through

Asleep upon their darksome beds,

The stars wer all awake, John.

Noo birds o' day wer out to spread

Their wings above the gully's bed,

An' darkness roun' the elem-tree

'D a-still'd the charmy childern's glee.

noisy

All he'ths wer cwold but woone, where we

Wer gaÿ, 'tis true, but gaÿ an' wise,

An' laugh'd in light o' maïdens' eyes,

That glissen'd wide awake, John.

An' when we all, lik' loosen'd hounds,

Broke out o' doors, wi' merry sounds,

Our friends among the plaÿsome team,

All brought us gwäin so vur's the stream.

came with us as far as

But Jeäne, that there, below a gleam

O' light, watch'd woone o's out o' zight;

one of us

Vor willènly, vor his "Good night,"

She'd longer bide awake, John.

An' while up Leighs we stepp'd along

Our grassy path, wi' joke an' zong, 
fə:Ifhed

twər (h)wər mə:I fondist ð๖:ts də lə:It ət fə:Ifhed (h)wə:Il wi: spent ðə nə:It ðə mIl(h)willz restən rim wər drə:I ən hə:unz held $\Lambda$ p ðər i:vmən krə:I ən lpfti dru: ðə mIdnə:It skə:I

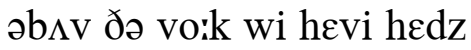
əsli:p əppn ðər da:rksəm bedz ðə sta:rz wər a:l əwjєk dzan

nu: bə:rdz ə de: wər ərut tə spred

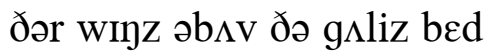
ən da:rknis rəiun ði عləmtri: d əstrld ðə t $\int a$ armi t t Ildərnz gli: a:l heӨs wər kuəld bət (w)uin (h)wər wi: wər gæi tIz tru: bət gæi ən wə:Iz ən le:ft In lə:It ə mæidənz ə:Iz ðət glisənd wə:Id əwjek dzan ən (h)wen wi: a:l lik lu:sənd hə:un(d)z bro:k ə:ut ə duərz wi meri səiun $(\mathrm{d}) \mathrm{z}$ ə:uər fren(d)z əmpy ðə plæısəm ti:m a:l bro:t əs gwæın sə və:rz ðə stri:m bət dzjen ðət ðər bılo: ə gli:m ə lə:It wpt $\int t$ (w)u:n o:s ərut ə zə:It var wilənli vər (h)Iz gud nə:It fiid longər bə:Id əwjek dzan ən (h)wə:ıl $\Lambda p$ li:z wi: stept əlpy ə:uər gra:si pe: $\theta$ wi dzo:k ən zpy 
There Plumber, wi' its woody ground, O' slopèn knaps a-screen'd around, billocks Rose dim 'ithout a breath o' sound, The wold abode o' squiers a-gone, old Though while they lay a-sleepèn on, Their stars wer still awake, John. 
ðər plımər wi Its wudi grə:un(d) ə slo:pən naps əskri:nd ərə:un(d) ro:z dim Iðə:ut ə bre日 ə sə:un(d) ðə (w)uəld əbo:d ə skwə:ıərz əgpn ðо: (h)wə:Il ðе: le: əsli:pən pn ðər sta:rz wər stıl əwjek dzan 
IF I've a-stream'd below a storm, An' not a-velt the rain, An' if I ever velt me warm,

In snow upon the plain,

'Twer when, as evenèn skies wer dim, An' vields below my eyes wer dim,

I went alwone at evenèn-fall,

Athirt the vields to Ivy Hall.

across

I voun' the wind upon the hill,

Last night, a-roarèn loud,

An' rubbèn boughs a-creakèn sh'ill

loudly

Upon the ashes' sh'oud;

canopy

But oh! the reelèn copse mid groan;

may

An' timber's lofty tops mid groan;

The hufflèn winds be music all, gusty

Bezide my road to Ivy Hall.

A sheädy grove o' ribbèd woaks, oaks

Is Wootton's shelter'd nest, An' woaks do keep the winter's strokes

Vrom Knapton's evenèn rest.

An' woaks ageän wi' bossy stems, trunks

An' elems wi' their mossy stems,

Do rise to screen the leafy wall

An' stwonèn ruf ov Ivy Hall.

stone roof

The darksome clouds mid fling their sleet, An' vrost mid pinch me blue, Or snow mid cling below my veet, An' hide my road vrom view. 
ว:Ivi ha:l

If ə:IV əstri:md bilo: ə sta:rm

ən npt əvعlt ðə ræIn

ən If ə:I Evər velt mi: wa:rm

In sno: əppn ðə plæIn

twər (h)wen az iivmən skəIIz wər dim

ən vi:l(d)z bilo: mə:I ə:Iz wər dim

ə:I went əluən ət i:vmənfa:1

əðə:rt ðə vi:l(d)z tu ə:Ivi ha:l

ə:I və:un(d) ðə win(d) əppn ðə hıl

leist nə:It əruərən lə:ud

ən r $\Lambda$ bən bə:uz əcri:kən $\int \mathrm{I} 1$

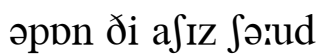

bət o: ðə ri:lən kpps mid gro:n

on timbərz lpfti tops mid gro:n

ðə hıflən win(d)z bi: mju:zik a:l

bIzə:Id mə:I ro:d tu ə:Ivi ha:l

ə Jjedi gro:v ə ribıd (w)uəks

IZ wutənz $\int \varepsilon l t ə r d$ nest

ən (w)uəks də ki(:)p ðə wintərz stro:ks

vrəm naptənz i:vmən rest

ən (w)uəks əgjen wi bpsi stemz

ən عləmz wi ठər mpsi stemz

də rə:Iz tə skri:n ðə li:fi wa:l

ən stuənən $\mathrm{r} \Lambda \mathrm{f}$ əv ərivi ha:l

ðə da:rksəm klə:udz mıd flın ðər sli:t

on vrost mid pint $\int \mathrm{mi}$ : blu:

ar sno: mid klin bilo: mə:I vi:t

ən hə:Id mə:I ro:d vrəm vju: 
The winter's only jaÿ ov heart, joy An' storms do meäke me gaÿ ov heart, When I do rest, at evenèn-fall, Bezide the he'th ov Ivy Hall. bearth

There leafy stems do clim' around The mossy stwonèn eaves; stone An' there be window-zides a-bound Wi' quiv'rèn ivy-leaves.

But though the sky is dim 'ithout, An' feäces mid be grim 'ithout, may Still I ha' smiles when I do call, At evenèn-tide, at Ivy Hall. 
ðə wintərz o:nli dzæı əv harrt

ən sta:rmz də mjek mi: gæi əv harrt

(h)wen əiI də rest ət iivmənfa:l

bızə:Id ðə he $\theta$ əv ə:Ivi ha:l

ðər li:fi stemz də klım ərə:un(d)

ðə mpsi stuənən i:vz

ən ðər bi: windərzə:Idz əbə:un(d)

wi kwivrən ə:Ivili:vz

bət ðо: ðə skə:I IZ dim ıðə:ut

ən fjesız mıd bi: grım ıðə'ut

stıl ə:I ha smə:Ilz (h)wen ə:I də ka:l

ət i:vməntə:Id ət ə:Ivi ha:l 
FALSE FRIENDS-LIKE

WHEN I wer still a bwoy, an' mother's pride,

A bigger bwoy spoke up to me so kind-like,

"If you do like, I'll treat ye wi' a ride

In theäse wheel-barrow here." Zoo I wer blind-like

this, so

To what he had a-workèn in his mind-like,

An' mounted vor a passenger inside;

An' comèn to a puddle, perty wide,

He tipp'd me in, a-grinnèn back behind-like.

Zoo when a man do come to me so thick-like,

friendly-

An' sheäke my hand, where woonce he pass'd me by,

once

An' tell me he would do me this or that,

I can't help thinkèn o' the big bwoy's trick-like.

An' then, vor all I can but wag my hat

raise

An' thank en, I do veel a little shy.

him 
fa:ls fren(d)zlik

(h)wen ə:I wər stıl ə bwə:I ən m^ðərz prə:Id ə bigər bwə:I spo:k $\Lambda$ p tə mi: sə kə:In(d)lik If ju: də lə:ık ə:Il tri:t i: wi ə rə:Id In ðiəs (h)wi:lbarə hiər zu: ə:I wər blə:In(d)lik tə (h)wpt ə had əwə:rkən In (h)Iz mə:In(d)lik ən mə:untid vər ə pasəndzər Insə:Id ən k $\Lambda$ mən tu ə p $\Lambda$ dəl pərrti wərid ə tipt mi: in əgrinən bak bihə:in(d)lik

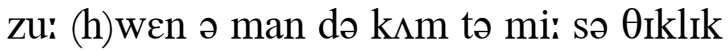
ən Sjek mə:I han(d) (h)wər (w)uins hi: paist mi: bə:I ən tel mi: ə wud du: mi: ðIs ər ðat

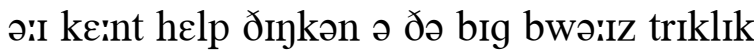
ən ðعn vər a:l ə:I kan bət wag mə:I hat ən $\theta$ ayk ən ə:I də viil ə litəl fə:I 
No! I don't begrudge en his life,

Nor his goold, nor his housen, nor lands;

Teäke all o’t, an' gi'e me my wife,

A wife's be the cheapest ov hands.

Lie alwone! sigh alwone! die alwone!

Then be vorgot.

No! I be content wi' my lot.

Ah! where be the vingers so feäir,

Vor to pat en so soft on the feäce,

bim

To mend ev'ry stitch that do tear,

An' keep ev'ry button in pleäce?

Crack a-tore! brack a-tore! back a-tore!

Buttons a-vled!

Vor want ov a wife wi' her thread.

flaw in clothing

flown away

Ah! where is the sweet-perty head

That do nod till he's gone out o' zight?

An' where be the two eärms a-spread,

arms

To show en he's welcome at night?

Dine alwone! pine alwone! whine alwone!

Oh! what a life!

I'll have a friend in a wife.

An' when vrom a meetèn o' me'th

mirth

Each husban' do leäd hwome his bride,

Then he do slink hwome to his he'th,

bearth

Wi' his eärm a-hung down his cwold zide.

arm

Slinkèn on! blinkèn on! thinkèn on!

Gloomy an' glum;

Nothèn but dullness to come. 
ðə bat $\int ə l ə r$

no: ə:I do:nt bigr $\Lambda$ d3 ən (h)Iz lə:If

nar (h)Iz gu:ld nar (h)Iz hə:uzən nər lan(d)z

tjek ail o:t ən gi: mi: mə:I wə:If

ə wə:Ifs bi: ðə tfi:pIst əv han(d)z

lə:I əluən sə:I əluən də:I əluən

ðعn bi: vərgpt

no: ə:I bi: kəntent wi mə:I lpt

a: (h)wər bi: ðə vingərz sə fjeər

vər to pat ən sə spft pn ठə fjes

tə mend عvri stit ðət də teər

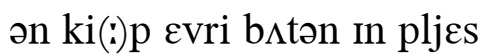

krak ətuər brak ətuər bak ətuər

bıtənz əvled

vər wont əv ə wəIIf wi (h)ər dred

a: (h)wər Iz ðə swi(:)tpə:rti hed

ðət də nod tıl hi:z gon ərut ə zə:It

ən (h)wər bi: ðə tu: ja:rmz əspred

to fo: ən hi:z welkəm ət nə:It

də:In əluən pə:In əluən (h)wə:In əluən

o: (h)wpt a lə:If

ว:Il hav ə fren(d) In ə wə:If

ən (h)wen vrəm ə miitən ə me $\theta$

i:t $h \wedge z b ə n$ də liəd huəm (h)Iz brə:Id

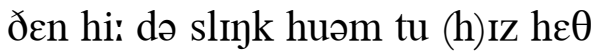

wi (h)Iz ja:rm əh^y də:un (h)Iz kuəld zə:Id

slıjkən pn blınkən pn ðınkən pn

glu:mi ən glım

$\mathrm{n} \Lambda \theta ə n$ bət $\mathrm{d} \Lambda \ln \mathrm{s}$ to $\mathrm{k} \wedge \mathrm{m}$ 
An' when he do onlock his door,

Do rumble as hollow's a drum, An' the veäries a-hid roun' the vloor,

fairies

Do grin vor to see en so glum.

bim

Keep alwone! sleep alwone! weep alwone!

There let en bide,

I'll have a wife at my zide.

But when he's a-laid on his bed

In a zickness, $\mathrm{O}$, what wull he do!

Vor the hands that would lift up his head,

An' sheäke up his pillor anew.

Ills to come! pills to come! bills to come!

Noo soul to sheäre

The trials the poor wratch must bear. 
ən (h)wen ə du $\Lambda$ nlpk (h)Iz duər

də rımbəl əz hplərz ə dr $\Lambda \mathrm{m}$

ən ðə vjeəriz əhıd rə:un ðə vluər

də grin vər tə zi: ən sə gl $\Lambda \mathrm{m}$

ki:p əluən sli:p əluən wi:p əluən

ðər let ən bə:Id

ə:Il hav ə wə:If ət mə:I zə:Id

bət (h)wen hi:z əled pn (h)Iz bed

In ə ziknis o: (h)wpt wul hi: du:

vər ðə han(d)z ðət wod lift $\Lambda p$ (h)Iz hed

ən $\int j \varepsilon k \mu p(h)$ IZ pilər ənju:

Ilz to k $\wedge \mathrm{m}$ pilz to k $\wedge \mathrm{m}$ bilz to k $\wedge \mathrm{m}$

nu: so:l to Jjeər

ðə trə:Iəlz ðə pu(:)ər rat $\int$ məs(t) beər 
COME let's goo down the grove to-night;

The moon is up, 'tis all so light

As day, an' win' do blow enough

To sheäke the leaves, but tiddèn rough.

'tisn't

Come, Esther, teäke, vor wold time's seäke, old

Your hooded cloke, that's on the pin, peg

An' wrap up warm, an' teäke my eärm, arm

You'll vind it better out than in.

Come, Etty dear; come out o' door,

An' teäke a sweetheart's walk woonce mwore.

once

How charmèn to our very souls,

Wer woonce your evenèn maïden strolls,

The while the zettèn zunlight dyed

Wi' red the beeches' western zide,

But back avore your vinger wore

The weddèn ring that's now so thin;

An' you did sheäre a mother's ceäre,

To watch an' call ye eärly in.

Come, Etty dear; come out o' door,

An' teäke a sweetheart's walk woonce mwore.

An' then ageän, when you could slight

The clock a-strikèn leäte at night,

The while the moon, wi' risèn rim,

Did light the beeches' eastern lim'.

When I'd a-bound your vinger round

Wi' thik goold ring that's now so thin,

An' you had nwone but me alwone

To teäke ye leäte or eärly in.

Come, Etty dear; come out o' door,

An' teäke a sweetheart's walk woonce mwore. 
marid pjeərz $1 \Lambda v$ we:k

k^m lets gu: də:un ðə gro:v tənə:It

ðə mu:n Iz $\Lambda$ p tIz a:l sə lə:it

əz de: ən win də blo: in $\Lambda f$

to $\int j \varepsilon k$ ðə liivz bət tıdən $\mathrm{r} \Lambda \mathrm{f}$

kım عstər tjek vər (w)uəld tə:Imz sjek

jər hudid klo:k ðəts pn ðə pın

ən rap $\Lambda \mathrm{p}$ wa:rm ən tjek mə:I ja:rm

jəl və:In(d) it betər ə:ut ðən in

$\mathrm{k} \wedge \mathrm{m}$ eti diər kım ərut ə duər

ən tjek ə swi(:)tharrts we:k (w)u:ns muər

hə:u t fa:rmən tu ə:uər veri so:lz

wər (w)u:ns jər i:vmən mæIdən stro:lz

ðə (h)wə:Il ðə zetən zınlə:It də:Id

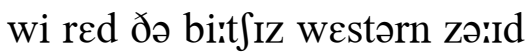

bət bak əvuər jər vingər wuər

ðə wedən rin ðəts nə:u sə ðIn

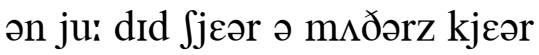

to wpt $\int$ ən ka:l i: jərrli in

$\mathrm{k} \wedge \mathrm{m}$ eti diər kım ərut ə duər

ən tjek ə swi(:)tha:rts we:k (w)u:ns muər

ən ðعn əgjen (h)wen ju: kud slə:It

ðə klpk əstrikən ljet ət nə:It

ðə (h)wə:Il ðə mu:n wi rə:Izən rim

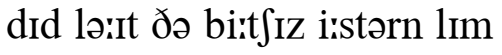

(h)wen ə:Id əbə:un(d) jər vingər rə:un(d)

wi ðık gu:ld rın ðəts nə:u sə ðın

ən ju: had nuən bət mi: əluən

tə tjek i: ljet ar jə:rli in

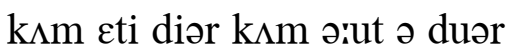

ən tjek ə swi(:)tharrts we:k (w)u:ns muər 
But often when the western zide

$O$ ' trees did glow at evenèn-tide,

Or when the leäter moon did light

The beeches' eastern boughs at night,

An' in the grove, where vo'k did rove

folk

The crumpled leaves did vlee an' spin,

fly

You couldèn sheäre the pleasure there:

Your work or childern kept ye in.

Come, Etty dear, come out o' door,

An' teäke a sweetheart's walk woonce mwore.

But ceäres that zunk your oval chin

Ageän your bosom's lily skin,

Vor all they meäde our life so black,

Be now a-lost behind our back.

Zoo never mwope, in midst of hope,

To slight our blessèns would be sin.

Ha! ha! well done, now this is fun;

When you do like I'll bring ye in.

Here, Etty dear; here, out o' door,

We'll teäke a sweetheart's walk woonce mwore. 
bət pfən (h)wعn ðə westərn zə:Id

a triiz did glo: at iivməntə:Id ar (h)wen ðə ljetər mu:n did lə:it

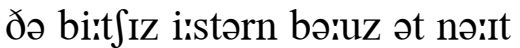
ən In ðə gro:v (h)wər vo:k did ro:v ðə krımpəld li:vz did vli: ən spın

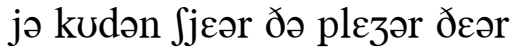
jər wə:rk ər tfrldərn kept i: in

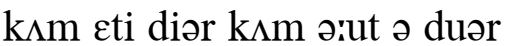
ən tjek ə swi(:)tha:rts we:k (w)u:ns muər

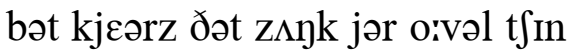
əgjen jər bᄉzəmz lili skin vər a:l ðe: mjed ə:uər lə:If sə blak bi: nə:u əlpst bihə:In(d) ə:uər bak zu: nevər muəp in midst əv ho:p to slə:it ə:uər blesənz wud bi: sin ha ha wel d $\Lambda$ n nə:u ðIs Iz f $\Lambda$ n (h)wen ju: də lə:ık ə:Il brin i: in hiər عti diər hiər ə'ut ə duər will tjek ə swi(:)tha:rts we:k (w)u:ns muər 
'TwER Maÿ, but ev'ry leaf wer dry

All day below a sheenèn sky;

shining

The zun did glow wi' yollow gleäre,

An' cowslips blow wi' yollow gleäre,

Wi' grægles' bells a-droopèn low,

bluebells'

An' bremble boughs a-stoopèn low;

While culvers in the trees did coo

doves

Above the vallèn dew.

falling

An' there, wi' heäir o' glossy black,

Bezide your neck an' down your back,

You rambled gaÿ a-bloomèn feäir;

By boughs o' maÿ a-bloomèn feäir;

An' while the birds did twitter nigh,

An' water weäves did glitter nigh,

You gather'd cowslips in the lew,

shelter

Below the vallèn dew.

An' now, while you've a-been my bride

As years o' flow'rs ha' bloom'd an' died,

Your smilèn feäce ha' been my jä̈;

Your soul o' greäce ha' been my jaÿ;

An' wi' my evenèn rest a-come,

An' zunsheen to the west a-come,

sunsbine

I'm glad to teäke my road to you

Vrom vields o' vallèn dew.

An' when the raïn do wet the maÿ,

A-bloomèn where we woonce did straÿ,

once

An' win' do blow along so vast,

fast

An' streams do flow along so vast; 
ə wə:If əpræızd

twər mæi bət عvri li:f wər drə:I a:l de: bilo: ə jiinən skə:I ðə zın did glo: wi jalər gljeər ən kə:uslıps blo: wi jalər gljeər wi gre:gəlz belz ədru:pən lo: ən brembəl bə:uz əstu:pən lo: (h)wə:Il kılvərz in ðə tri:z did ku:

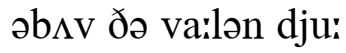

ən ðər wi hjeər ə glosi blak bizə:Id jər nek ən də:un jər bak ju: rambəld gæi əblu:mən fjeər b(ə:)I bə:uz ə mæi əblu:mən fjeər ən (h)wə:Il ðə bə:rdz did twitər nə:I ən wo:tər wjevz did glitər nə:I jə gaðərd kə‘uslips in ðə lu: bilo: ðə va:lən dju:

ən nə:u (h)wə:Il ju:v əbın mə:I brə:Id az jiərz ə flə:uərz hə blu:md ən də:Id jər smə:Iən fjes hə bin mə:I dzæI jər so:l ə grjes hə bIn mə:I dzæI ən wi mə:I iivmən rest əkım

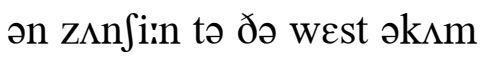
ə:Im glad to tjek mə:I ro:d tə ju: vrəm vi:l(d)z ə va:lən dju:

ən (h)wعn ðə ræIn də wet ðə mæI əblu:mən (h)wər wi: (w)urns did stræI ən $\operatorname{win}(d)$ də blo: əlpy sə vaist ən stri:mz də flo: əlpy sə va:st 
Ageän the storms so rough abroad,

An' angry tongues so gruff abroad,

The love that I do meet vrom you

Is lik' the vallèn dew.

An' you be sprack's a bee on wing,

lively

In search ov honey in the Spring:

The dawn-red sky do meet ye up;

The birds vu'st cry do meet ye up;

first

An' wi' your feäce a-smilèn on,

An' busy hands a-tweilèn on,

toiling

You'll vind zome useful work to do

Until the vallèn dew. 
əgjen ðə sta:rmz sə rıf əbro:d

ən angri t $\Lambda \mathrm{yz}$ sə gr $\Lambda$ f əbro:d

ðə $1 \Lambda \mathrm{v}$ ठət ə:I də mi(:)t vrəm ju:

Iz lik ðə va:lən dju:

ən ju: bi: spraks ə bi: pn win

In sairt $\int$ əv h^ni In ठə sprin

ðə de:nred skə:I də mi(:)t i: $\Lambda p$

ðə bə:rdz v $\Lambda$ st krə:I də mi(:)t i: $\Lambda p$

ən wi jər fjes əsmə:ilən pn

ən bizi han (d)z ətwə:Ilən pn

ju:l və:In(d) z^m ju:sful wərrk to du:

ıntıl ðə va:lən dju: 
SINCE I noo mwore do zee your feäce,

Up steäirs or down below,

I'll zit me in the lwonesome pleäce,

Where flat-bough'd beech do grow:

Below the beeches' bough, my love,

Where you did never come,

An' I don't look to meet ye now,

As I do look at hwome.

Since you noo mwore be at my zide,

In walks in zummer het,

I'll goo alwone where mist do ride,

Drough trees a-drippèn wet:

Below the raïn-wet bough, my love,

Where you did never come,

An' I don't grieve to miss ye now,

As I do grieve at home.

Since now bezide my dinner-bwoard

Your vaïce do never sound,

I'll eat the bit I can avword,

A-vield upon the ground;

Below the darksome bough, my love,

Where you did never dine,

An' I don't grieve to miss ye now,

As I at hwome do pine.

Since I do miss your vaïce an' feäce

In praÿer at eventide,

I'll praÿ wi' woone sad vaïce vor greäce

To goo where you do bide; 
ðə พə:If əlpst

sins ə:I nu: muər də zi: jər fjes

$\Lambda \mathrm{p}$ stjeərz ar də:un bilo:

ə:Il zit mi: in ðə luənsəm pljes

(h)wər flatbə:ud bi:ts də gro:

bılo: ðə bi:t $\int \mathrm{Iz}$ bə:u mə:I $1 \Lambda \mathrm{v}$

(h)wər ju: did nevər kım

ən ə:I do:nt luk to mi(:)t i: nə:u

az ə:I də luk ət huəm

sins ju: nu: muər bi: at mə:I zə:Id

In we:ks in zムmər het

əsil gu: əluən (h)wər mist də rə:Id

dru: tri:z ədripən wet

bilo: ðə ræinwet bə:u mə: $1 \Lambda \mathrm{V}$

(h)wər ju: did nevər kım

ən ə:I do:nt griiv tə mis i: nə:u

az ə:I də griiv ət huəm

sins nə:u bizə:Id mə:I dinərbuərd

ju(:)ər væIs də nevər sə:un(d)

ə:Il i:t ðə bit ə:I kən əvuərd

əvi:l(d) əppn ðə grə:un(d)

bılo: ðə da:rksəm bə:u mə:I $1 \Lambda \mathrm{V}$

(h)wər ju: did nevər də:In

ən ə:I do:nt griiv tə mis i: nə:u

az ə:I ət huəm də pə:In

sIns ə:I də mIs jər væIs ən fjes

In præiər at iivəntəitd

ə:Il præI wi (w)uin sad væIs vər grjes

tə gu: (h)wər ju: də bə:Id 
Above the tree an' bough, my love, Where you be gone avore, An' be a-waïtèn vor me now,

To come vor evermwore. 
əb $\Lambda \mathrm{v}$ ðə tri: ən bə:u mə:I $1 \Lambda \mathrm{v}$

(h)wər ju: bi: gon əvuər

ən bi: əwæitən vər mi: nə:u

to kım var evərmuər 
AH! Meäster Collins overtook

Our knot o' vo'k a-stannèn still, folk standing

Last Zunday, up on Ivy Hill,

To zee how strong the corn did look.

An' he staÿ 'd back awhile an' spoke

A vew kind words to all the vo'k, few

Vor good or joke, an' wi' a smile

Begun a-plaÿèn wi' a chile.

The zull, wi' iron zide awry, plough

Had long a-vurrow'd up the vield;

The heavy roller had a-wheel'd

It smooth vor showers vrom the sky;

The bird-bwoy's cry, a-risèn sh'ill, shrilly

An' clacker, had a-left the hill,

All bright but still, vor time alwone

To speed the work that we'd a-done.

Down drough the wind, a-blowèn keen, through

Did gleäre the nearly cloudless sky, An' corn in bleäde, up ancle-high, 'Ithin the geäte did quiver green; An' in the geäte a-lock'd there stood A prickly row o' thornèn wood Vor vo'k vor food had done their best, bring to fruition An' left to Spring to do the rest.

“The geäte," he cried, "a-seal'd wi' thorn Vrom harmvul veet's a-left to hold

The bleäde a-springèn vrom the mwold, earth While God do ripen it to corn. 
ðə ða:rnz In ðə gjet

a: mja:stər kplinz ərvərtuk ə:uər npt ə vo:k əstanən stil le:st zınde: $\Lambda p$ pn ə:Ivi hil to zi: hə'u strpy ðə ka:rn did luk ən hi: stæId bak ə(h)wə:Il ən spo:k ə vju: kə:In(d) wərrdz tu a:l ðə vo:k vər gud ər dzo:k ən wi ə smə:Il

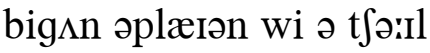

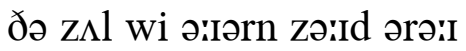
had lpy əv $\Lambda$ rə(r)d $\Lambda$ p ðə vi:ld ðə hevi ro:lər had ə(h)wild It smu:ð vər Јə:uərz vrəm ðə skə:I ðə bə:rdbwə:Iz krə:I ərə:Izən $\int \mathrm{l} l$ ən klakər had əleft ðə hil a:l brə:It bət stil vər tə:Im əluən tə spi:d ðə wərrk ðət wi:d əd $\Lambda$ n də:un dru: ðə win(d) əblo:ən ki:n dıd gljeər ðə niərli klə:udlıs skə:I ən ka:rn in bljed $\Lambda$ p ạkəlhə:I ıðın ðə gjet dıd kwıvər gri:n ən In ðə gjet əlpkt ðər stud ə prikli ro: ə ða:rnən wud vər vo:k vər fud had d $\mathrm{n}$ ðər best ən left tə sprin tə du: ðə rest

ðə gjet hi: krə:Id əsi:ld wi ða:rn vrəm ha:rmvul viits əleft to huəld ðə bljed əsprinən vrəm ðə muəld (h)wə:Il gpd də rə:Ipən it tə ka:rn 
An' zoo in life let us vulvil

Whatever is our Meäker's will,

An' then bide still, wi' peacevul breast,

While He do manage all the rest." 
ən zu: in lə:If let $\Lambda$ s vulvil

(h)wptevər IZ əruər mjekərz wil ən ठعn bə:Id strl wi pissvul brest (h)wə:Il hi: də manıdz a:l ðə rest 
$\mathrm{OH}$ ! there be angels evermwore, A-passèn onward by the door, A-zent to teäke our jaÿs, or come To bring us zome-O Meärianne.

Though doors be shut, an' bars be stout, Noo bolted door can keep em out;

But they wull leäve us ev'ry thing They have to bring-My Meärianne.

An' zoo the days a-stealèn by, so

Wi' zuns a-ridèn drough the sky, through

Do bring us things to leäve us sad,

Or meäke us glad-O Meärianne.

The day that's mild, the day that's stern, Do teäke, in stillness, each his turn; An' evils at their worst mid mend, may

Or even end-My Meärianne.

But still, if we can only bear

Wi' faith an' love, our païn an' ceäre,

We shan't vind missèn jaÿs a-lost,

Though we be crost-O Meärianne.

But all a-took to heav'n, an' stow'd

Where we can't weäste em on the road, As we do wander to an' fro,

Down here below-My Meärianne.

But there be jaÿs I'd soonest choose

To keep, vrom them that I must lose;

Your workzome hands to help my tweil, toil Your cheerful smile_-O Meärianne. 
andzəlz b(ə:)I ðə duər

o: ðər bi: andzəlz عvərmuər әpaisən pn(w)ərd b(ə:)I ठə duər əzent to tjek ə:uər dzæIz ar kım to brin əs zAm o: mjeərian ðо: duərz bi: $\int \Lambda \mathrm{t}$ ən ba:rz bi: stə:ut nu: bo:ltıd duər kən ki(:)p əm ərut bət ðe: wul liəv əs عvri ðın ðe: hav to brin mə:I mjeərian

ən zu: ðə de:z əsti:lən bə:I wi z^nz ərə:Idən dru: ðə skə:I də brin əs ðıinz tə liəv əs sad ar mjek əs glad o: mjeərian ðə de: ðəts mə:Ild ðə de: ðəts stə:rn də tjek in strlnis itt (h)Iz tə:rn ən i:vəlz ət ðər w $\Lambda$ st mId mend ər iivən end mə:I mjeərian

bət strl If wi: kən o:nli beər wi fæI $\theta$ ən $1 \Lambda \mathrm{v}$ ə:uər pæin ən kjeər wi: $\int a n t$ və:In(d) misən dzæIz əlpst ðo: wi: bi: krost o: mjeərian bət a:l atuk to hevn ən sto:d (h)wər wi: ke:nt wjest əm pn ðə ro:d əz wi: də wpndər tu: ən fro: dərun hiər bilo: mə: mjeərian

bət ðər bi: dzæız ə:Id su:nist t $\int u: z$ tə ki(:)p vrəm ðعm ðət ə:I məst luiz jər wə:rkzəm han $(\mathrm{d}) \mathrm{z}$ tə help mə:I twə:Il jər t $\int$ iərful smə:il o: mjeərian 
The Zunday bells o' yonder tow'r,

The moonlight sheädes o' my own bow'r,

shadows

An' rest avore our vier-zide,

fireside

At evenèn-tide-My Meärianne. 
ðə zムnde: belz ə jandər təruər ðə mu:nlə:It $\int j \varepsilon d z$ ə mə:I o:n bə:uər ən rest əvuər ə:uər və:Iərzə:Id at i.vməntə:Id mə:I mjeərian 
THE church do zeem a touchèn zight,

When vo'k, a-comèn in at door,

Do softly tread the long-ail'd vloor -aisled

Below the pillar'd arches' height,

Wi' bells a-pealèn,

Vo'k a-kneelèn,

Hearts a-healèn, wi' the love

An' peäce a-zent em vrom above.

An' there, wi' mild an' thoughtvul feäce,

Wi' downcast eyes, an' vaïces dum',

The wold an' young do slowly come, silent

An' teäke in stillness each his pleäce,

A-zinkèn slowly,

Kneelèn lowly,

Seekèn holy thoughts alwone,

In praÿ’r avore their Meäker's throne.

An' there be sons in youthvul pride,

An' fathers weak wi' years an' païn,

An' daughters in their mother's train,

The tall wi' smaller at their zide;

Heads in murnèn

mourning

Never turnèn,

Cheäks a-burnèn, wi' the het

beat

O' youth, an' eyes noo tears do wet.

There friends do settle, zide by zide,

The knower speechless to the known;

Their vaice is there vor God alwone;

To flesh an' blood their tongues be tied. 
vo:k əkımən Intə t $\int ə: r t \int$

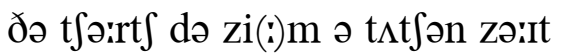

(h)wen vo:k əkımən in ət duər

də spf(t)li tred ðə lpyæıl(d) vluər

bilo: ðə pilərd airt $\int \mathrm{Iz}$ hə:It

wi belz əpi:lən

vo:k əni:lən

ha:rts əhi:lən wi ðə $1 \Lambda \mathrm{v}$

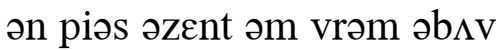

ən ðər wi mə:Ild ən $\theta$ stvul fjes

wi dərunkaist ə:IZ ən væIsIz $\mathrm{d} \Lambda \mathrm{m}$

ðə (w)uəld ən j^y də slo:li kım

ən tjek In strlnis i:t (h)Iz pljes

əzınkən slo:li

ni:lən lo:li

si:kən ho:li ðo:ts əluən

In præIr əvuər ðər mjekərz Өro:n

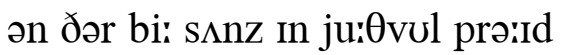

on fe:ðərz wi:k wi jiərz ən pæin

ən de:tərz In ðər m^ðərz træIn

ðə ta:l wi sma:lər ət ðər zə:Id

hedz in mə:rnon

nevər tə:rnən

t fiəks əbə:rnən wi ðə het

ə ju: $\theta$ ən ə:Iz nu: tiərz də wet

ðعər fren(d)z də setəl zə:Id b(ə:)I zə:Id

ðə no:ər spi:tflis tə ðə no:n

ðər væIS IZ ðعər vər gpd əluən

to fles ən blıd ðər tıyz bi: tə:Id 
Grief a-wringèn,

Jaÿ a-zingèn,

joy

Pray'r a-bringèn welcome rest

So softly to the troubled breast. 


\author{
griif əringən \\ dzæi əzingən \\ præIr əbrijən welkəm rest \\ sə $\operatorname{spf}(\mathrm{t})$ li tə ðə trıbəld brest
}


AN' while I zot, wi' thoughtvul mind, sat

Up where the lwonesome Coombs do wind, An' watch'd the little gully slide

So crookèd to the river-zide;

I thought how wrong the Stour did zeem

To roll along his ramblèn stream,

A-runnèn wide the left o' south,

To vind his mouth, the right-hand zide.

But though his stream do teäke, at mill, An' eastward bend by Newton Hill, An' goo to lay his welcome boon O' daily water round Hammoon, An' then wind off ageän, to run

By Blanvord, to the noonday zun, 'Tis only bound by woone rule all, An' that's to vall down steepest ground.

An' zoo, I thought, as we do bend so

Our waÿ drough life, to reach our end, Our God ha' gi'ed us, vrom our youth, through Woone rule to be our guide-His truth. given An' zoo wi' that, though we mid teäke may

Wide rambles vor our callèns' seäke, What is, is best, we needen fear, An' we shall steer to happy rest. 
(w)u:n ru:l

วn (h)wə:Il ə:I zat wi $\theta$ :tvul mə:in(d)

$\Lambda \mathrm{p}$ (h)wər ðə luənsəm ku:mz də wə:In(d)

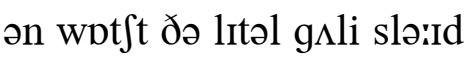

sə krukid tə ðə rivərzə:Id

ə:I ðว:t hə:u ron ðə stə:uər did zi:m

to ro:l alpn (h)Iz ramblon stri:m

วr $\Lambda$ nən wə:Id ðə left ə sə:u $\theta$

tə və:In(d) (h)Iz mə:u $\theta$ ðə rə:Ithan(d) zə:Id

bət ðо: (h)IZ stri:m də tjek ət mil

ən iistwərd ben(d) b(ə:)I njuitən hil

ən gu: tə le: (h)Iz welkəm buin

ə de:li wortər rə:un(d) hamuin

ən ðعn wə:In(d) pf əgjen tə r $\Lambda$ n

b(ə:)I blanvərd tə ðə nuinde: z $\Lambda$ n

tIz o:nli bə:un(d) b(ə:)I (w)u:n ruil ail

ən ðats tə vail dərun sti:pist grə:un(d)

วn zu: ə:I ðว:t əz wi: də ben(d)

ว:uər wæI dru: lə:If tə ri:t

ə:uər god hə gi:d əs vrəm ə:uər ju: $\theta$

(w)uin ruil tə bi: ə:uər gə:Id hIz trui $\theta$

ən zu: wi ðat ðo: wi: mid tjek

wə:Id rambəlz vər ə:uər ka:lənz sjek

(h)wDt Iz Iz best wi: ni:dən fiər

ən wi: $\int ə 1$ stiər to hapi rest 


\section{GOOD MEÄSTER COLLINS}

AYE, Meäster Collins wer a-blest

Wi' greäce, an' now's a-gone to rest;

An' though his heart did beät so meek

'S a little child's, when he did speak,

The godly wisdom ov his tongue

Wer dew o' greäce to wold an' young.

'Twer woonce, upon a zummer's tide, once

I zot at Brookwell by his zide, sat

Avore the leäke, upon the rocks,

Above the water's idle shocks,

As little plaÿsome weäves did zwim

Ageän the water's windy brim,

Out where the lofty tower o' stwone

Did stan' to years o' wind an' zun;

An' where the zwellèn pillars bore

A pworch above the heavy door,

Wi' sister sheädes a-reachèn cool

Athirt the stwones an' sparklèn pool.

shadows

I spoke zome word that meäde en smile,

across

O' girt vo'k's wealth an' poor vo'k's tweil,

bim

As if I pin'd, vor want ov greäce,

To have a lord's or squier's pleäce.

"No, no," he zaid, "what God do zend

Is best vor all o's in the end,

An' all that we do need the mwost

Do come to us wi' leäst o' cost; -

Why, who could live upon the e'th

earth

'Ithout God's gift ov aïr vor breath?

Or who could bide below the zun

If water didden rise an' run?

didn't 
gud mja:stər kplinz

æı mja:stər kplınz wər əblest wi grjes ən nə:uz əgpn tə rest ən ðo: (h)Iz hairt did biət sə mi:k s ə litəl tfə:Il(d)z (h)wen hi: did spi:k ðə gpdli wIzdəm əv (h)Iz t $\Lambda$ y wər dju: ə grjes tə (w)uəld ən j $\wedge$ y

twər (w)u:ns əppn ə z^mərz tə:Id ə:I zat ət brukwel b(ə:)I (h)Iz zə:Id әvuər ðə ljek әppn ðə rpks əb $\Lambda \mathrm{v}$ ðə wə:tərz ə:Idəl $\int \mathrm{pks}$ az litəl plæisəm wjevz did zwim əgjen ðə wə:tərz windi brim ə:ut (h)wər ðə lpfti tə:uər ə stuən did stan to jiərz ə win(d) ən z $\mathrm{n}$ ən (h)wər ðə zwelən pilərz buər

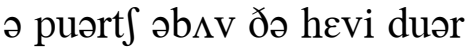
wi sistər $\int j \varepsilon d z$ əri:t $\int ə n$ ku:l əðə:rt ðə stuənz ən spa:rklən pu:l

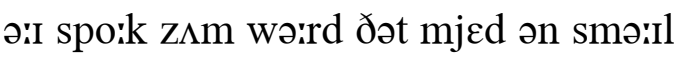
ə gə:rt vo:ks wel $\theta$ ən pu(:)ər vo:ks twə:Il əZ If ə:I pə:Ind vər wpnt əv grjes to hav ə la:rdz ər skwə:ıərz pljes no: no: ə zed (h)wpt gpd də zen(d) Iz best vər a:l o:s in ði en(d) ən a:l ðət wi: də ni:d ðə muəst də kım tu əs wi liəst a kpst (h)wə:I hu: kud liv əppn ði $\varepsilon \theta$ Iðə:ut gpdz gift əv æIr vər bre $\theta$ ar hu: kud bə:Id bilo: ðə z^n If wo:tər didən rə:Iz ən $\mathrm{r} \wedge \mathrm{n}$ 
An' who could work below the skies

If zun an' moon did never rise?

Zoo air an' water, an' the light,

Be higher gifts, a-reckon'd right,

Than all the goold the darksome claÿ

Can ever yield to zunny daÿ:

But then the air is roun' our heads,

Abroad by day, or on our beds;

outside

Where land do gi'e us room to bide, give

Or seas do spread vor ships to ride;

An' He do zend his waters free,

Vrom clouds to lands, vrom lands to sea;

An' mornèn light do blush an' glow,

'Ithout our tweil—'ithout our ho.

toil, care

"Zoo let us never pine, in sin, so

Vor gifts that ben't the best to win;

The heaps o' goold that zome mid pile, may

Wi' sleepless nights an' peaceless tweil;

Or manor that mid reach so wide

As Blackmwore is vrom zide to zide,

Or kingly swaÿ, wi' life or death,

Vor helpless childern ov the e'th:

earth

Vor theäse ben't gifts, as He do know, these

That He in love should vu'st bestow; first

Or else we should have had our sheäre

O'm all wi' little tweil or ceäre.

of them

"Ov all His choicest gifts, His cry

Is, 'Come, ye moneyless, and buy.'

Zoo blest is he that can but lift

so

His praÿer vor a happy gift." 
ən hu: kud wə:rk bilo: ðə skə:Iz

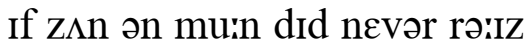

zu: æIr ən wo:tər ən ठə lə:It

bi: hə:ıər gifts ərekənd rə:It

ðən a:l ðə gu:ld ðə da:rksəm kle:

kən evər ji:l(d) to zムni de:

bət ðعn ði æIr IZ rə:un ə:uər hedz

əbro:d b(ə:)I de: ar pn ə:uər bedz

(h)wər lan(d) do gi: əs ru:m to bə:Id

ar si:z də spred vor $\int \mathrm{Ips}$ tə rə:Id

ən hi: də $z \varepsilon n(d)$ (h)Iz woitərz fri:

vrəm klə:udz tə lan(d)z vrəm lan(d)z tə si:

ən ma:rnən lə:it də bl $\Lambda \int$ ən glo:

ıðə:ut ə:uər twə:ıl ıðə'ut ə:uər ho:

zu: let əs nevər pəiIn in sin

vər gifts ðət be:nt ðə best tə win

ðə hi:ps ə gu:ld ðət z^m mid pə:Il

wi sli:plis nə:Its ən pisslis twə:il

ar manər ðət mId ri:t s sə wə:Id

əz blakmuər Iz vrəm zə:Id to zə:Id

ar kınli swæi wi lə:If or d $\mathrm{d} \theta$

vər helplis t trildərn əv ði $\varepsilon \theta$

vər ðiəz be:nt gifts əz hi: də no:

ðət hi: in $1 \Lambda \mathrm{v} \int u d \mathrm{v} \Lambda \mathrm{st}$ bisto:

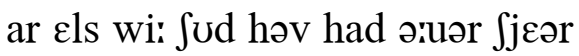

o:m a:l wi litəl twə:Il ər kjeər

əv a:l (h)Iz tfæisıst gifts (h)Iz krə:I

IZ kım (j)i: m $\wedge$ nilis ən(d) bə:I

zu: blest Iz hi: ðət kan bət lift

(h)IZ præıər vər ə hapi gift 


\section{HERRENSTON}

Zoo then the leädy an' the squier,

so

At Chris'mas, gather'd girt an' small, great

Vor me'th, avore their roarèn vier,

An' roun' their bwoard, 'ithin the hall; mirth, fire table

An' there, in glitt'rèn rows, between

The roun'-rimm'd pleätes, our knives did sheen,

shine

Wi' frothy eäle, an' cup an' can, ale

Vor maïd an' man, at Herrenston.

An' there the jeints o' beef did stand,

Lik' cliffs o' rock, in goodly row;

Where woone mid quarry till his hand one might

Did tire, an' meäke but little show;

An' after we'd a-took our seat,

An' greäce had been a-zaid vor meat,

We zet to work, an' zoo begun

food

Our feäst an' fun at Herrenston.

An' mothers there, bezide the bwoards,

Wi' little childern in their laps,

Did stoop, wi' lovèn looks an' words,

An' veed em up wi' bits an' draps;

An' smilèn husbands went in quest

O' what their wives did like the best;

An' you'd ha' zeed a happy zight, seen

Thik merry night, at Herrenston.

that

An' then the band, wi' each his leaf

O' notes, above us at the zide,

Plaÿ'd up the praïse ov England's beef

An'vill'd our hearts wi' English pride; 
herənstən

zu: ðعn ठə ljedi ən ðə skwə:ıər ot krisməs gaðərd gərrt ən sma:l vər mع $\theta$ əvuər ðər ruərən və:Iər ən rə:un ðər buərd ıðın ðə ha:l ən ðər In glitrən ro:z bitwi:n ðə rə:unrımd pljets ə:uər nə:IVZ did Ji:n wi fro $\theta \mathrm{i}$ jel ən kıp ən kan vər mæId ən man ət herənstən

ən ðər ðə dzə:Ints ə bi:f did $\operatorname{stan}(\mathrm{d})$ lik klıfs ə rok in gudli ro: (h)wər (w)u:n mid kwari til (h) Iz han(d) did təiır on mjek bət litəl fo: ən عitər wi:d ətuk əiuər si:t ən grjes had bin əzed vor mi:t wi: zet to wərk ən zu: big ə:uər fiəst ən fın ət herənstən

ən m^ðərz ðər bizə:Id ðə buərdz wi litəl t $\int \mathrm{Ild}$ ldrn in ðər laps

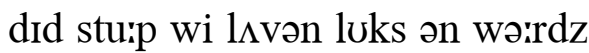
ən vi:d əm $\Lambda$ p wi bits ən draps ən smə:ilən h $\Lambda$ zbən(d)z went in kwest ə (h)wpt ðər wə:IVz did lə:Ik ðə best ən ju:d hə zi:d ə hapi zə:it ðIk meri nə:It ət herənstən

ən ðعn ðə ban(d) wi i:t (h)Iz li:f ə no:ts əb $\Lambda \mathrm{V}$ əs ət ðə zə:Id plæıd $\Lambda$ p ðə præız əv Inglən(d)z bi:f ən vild ə:uər hairts wi inglis prə:Id 
An' leafy chaïns o' garlands hung,

Wi' dazzlèn stripes o' flags, that swung

Above us, in a bleäze o' light,

Thik happy night, at Herrenston.

that

An' then the clerk, avore the vier, fire

Begun to leäd, wi' smilèn feäce,

A carol, wi' the Monkton quire,

That rung drough all the crowded pleäce.

through

An' dins' o' words an' laughter broke

In merry peals drough clouds o' smoke;

Vor hardly wer there woone that spoke,

one

But pass'd a joke, at Herrenston.

Then man an' maïd stood up by twos,

In rows, drough passage, out to door,

An' gaily beät, wi' nimble shoes,

A dance upon the stwonèn floor.

stone

But who is worthy vor to tell,

If she that then did bear the bell,

Wer woone o' Monkton, or o' Ceäme,

Or zome sweet neäme ov Herrenston.

Zoo peace betide the girt vo'k's land, so, great folk's

When they can stoop, wi' kindly smile, An' teäke a poor man by the hand,

An' cheer en in his daily tweil.

bim, toil

An' oh! mid He that's vur above

may, far

The highest here, reward their love,

An' gi'e their happy souls, drough greäce,

give

A higher pleäce than Herrenston. 
ən li:fi t fæinz ə ga:rlən(d)z h^y wi dazlən strə:Ips ə flagz ðət swıy

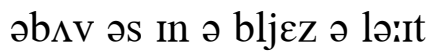
ðIk hapi nə:It ət herənstən

ən ðعn ðə kla:rk əvuər ðə və:ıər bigın to liəd wi sməillən fjes ə karəl wi ðə m^џktən kwə:ıər ðət rıy dru: a:l ðə krə:udıd pljes ən dinz ə wə:rdz ən le:ftər bro:k In meri pi:lz dru: klə:udz ə smo:k vər ha:rdli wər ठər (w)u:n ðət spo:k bət pa:st ə dzo:k ot herənstən

ðعn man ən mæId stud $\Lambda p$ b(ə:) I tu:z In ro:z dru: pasidz ə'ut to duər ən gæili biət wi nImbəl Ju:z ə de:ns əppn ðə stuənən vluər bət hu: IZ wərrði vər tə tel If $\int i$ ðət ðعn did beər ðə bel wər (w)u:n ə m^yktən ər ə kjem

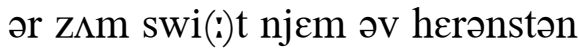

zu: pi:s bitə:Id ðə gə:rt vo:ks lan(d)

(h)wen ðe: kən stu:p wi kə:In(d)li smə:Il ən tjek ə pu(:)ər man b(ə:)I ठə han(d) ən t $\mathrm{t}$ iər ən In (h)Iz de:li twə:il ən o: mId hi: ठəts vərr əb $\Delta \mathrm{v}$ дə hə:IIst hiər riwa:rd ðər $1 \Lambda \mathrm{v}$ ən gi: ðər hapi so:lz dru: grjes ə hə:ıər pljes ðən herənstən 


\section{OUT AT PLOUGH}

THOUGH cool avore the sheenèn sky shining

Do vall the sheädes below the copse, shadows

The timber-trees, a-reachèn high, Ha' zunsheen on their lofty tops, sunshine

Where yonder land's a-lyèn plow'd, An' red, below the snow-white cloud, An' vlocks o' pitchèn rooks do vwold fold Their wings to walk upon the mwold, earth

While floods be low,

An' buds do grow,

$$
\text { An' aïr do blow, a-broad, O. }
$$

outside

But though the air is cwold below

The creakèn copses' darksome screen, The truest sheäde do only show

How strong the warmer zun do sheen; shine

An' even times o' grief an' païn, $\mathrm{Ha}$ ' good a-comèn in their traïn, An' 'tis but happiness do mark The sheädes o' sorrow out so dark.

As tweils be sad, toils

Or smiles be glad,

Or times be bad, at hwome, $\mathrm{O}$.

An' there the zunny land do lie

Below the hangèn, in the lew, slope, shelter Wi' vurrows now a-crumblèn dry, Below the plowman's dousty shoe; dusty An' there the bwoy do whissel sh'ill, tunefully

Below the skylark's merry bill, Where primrwose beds do deck the zides O’ banks below the meäple wrides. clumps 
ə:ut at plə:u

ðо: kuil əvuər ðə fi:nən skə:I

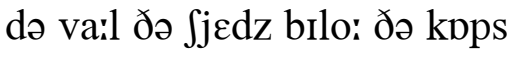

ðə tImbərtri:z əri:tðən hə:I

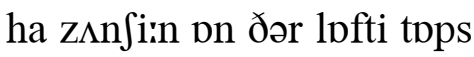

(h)wər jandər lan(d)z ələ:ıən plərud

ən red bilo: ðə sno:(h)wə:It klə:ud

ən vlpks ə pitfən ruks də vuəld

ðər winz tə we:k əppn ðə muəld

(h)wə:Il fl $\Lambda \mathrm{dz}$ bi: lo:

ən b $\Lambda \mathrm{dz}$ də gro:

ən æIr də blo: əbro:d o:

bət ðo: ði æır Iz kuəld bilo:

ðə kri:kən kppsız da:rksəm skri:n

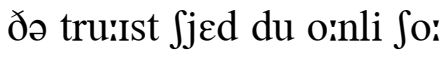

hə:u strpy ðə wa:rmər z^n də Ji:n

ən iivən tə:Imz ə griif ən pæin

ha gud əkımən In ðər træIn

ən tız bət hapinis də mark

ðə $\int j \varepsilon d z$ ə sarə(r) ə:ut sə da:rk

az twə:Ilz bi: sad

ar smə:Ilz bi: glad

ar tə:Imz bi: bad ət huəm o:

ən ðər ðə z^ni lan(d) də lə:I

bilo: ðə hayən in ðə lu:

wi vırə(r)z nə:u əkr $\wedge$ mblən drə:I

bilo: ðə plə:umənz dərusti Ju:

ən ðər ðə bwə:I də (h)wisəl $\int \mathrm{ll}$

bılo: ðə skə:ıla:rks meri bil

(h)wər primruəz bedz də dek ðə zə:Idz

ə bayks bilo: ðə mjepəl rə:Idz 
As trees be bright

Wi' bees in flight,

An' weather's bright, abroad, $\mathrm{O}$.

outside

An' there, as sheenèn wheels do spin

shining

Vull speed along the dousty rwoad,

dusty

He can but stan', an' wish 'ithin

His mind to be their happy lwoad,

That he mid gaily ride, an' goo

might

To towns the rwoad mid teäke en drough,

him, through

An' zee, for woonce, the zights behind

once

The bluest hills his eyes can vind,

O' towns, an' tow'rs,

An' downs, an' flow'rs,

In zunny hours, abroad, O.

But still, vor all the weather's feäir,

Below a cloudless sky o' blue,

The bwoy at plough do little ceäre

How vast the brightest day mid goo;

Vor he'd be glad to zee the zun

A-zettèn, wi' his work a-done,

That he, at hwome, mid still injaÿ

enjoy

His happy bit ov evenèn plaÿ,

So light's a lark

Till night is dark,

While dogs do bark, at hwome, O. 
əz tri:z bi: brə:It

wi bi:z in flə:it

ən weðərz brə:It əbro:d o:

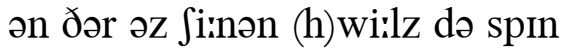

vul spi:d əlpy ðə də:usti ruəd

hi: kan bət stan ən WIS IðIn

(h)Iz mə:in(d) to bi: ðər hapi luəd

ðət hi: mid gæili rə:Id ən gu:

tə tə:unz ðə ruəd mid tjek ən dru:

ən zi: var (w)u:ns ðə zə:Its bihə:In(d)

ðə blu:ist hilz (h)Iz ə:Iz kən və:In(d)

ə tə:unz ən tə:uərz

ən dərunz ən fləruərz

In z^ni əruərz əbro:d o:

bət stıl vər a:l ðə wعðərz fjeər

bilo: ə klə:udlis skə:I a blu:

ðə bพə:I ət plə:u də litəl kjeər

hə:u va:st ðə brə:ItIst de: mId gu:

var hi:d bi: glad tə zi: ðə zムn

əzctən wi (h)Iz wərrk əd $\Lambda \mathrm{n}$

ðət hi: ət huəm mid stıl IndzæI

(h)Iz hapi bit əv i:vmən plæI

sə lə:its ə lairk

til nə:It IZ da:rk

(h)wəril dpgz də ba:rk ət huəm o: 
WHERE cows did slowly seek the brink

O' Stour, drough zunburnt grass, to drink; through

Wi' vishèn float, that there did zink fishing

An' rise, I zot as in a dream. sat

The dazzlèn zun did cast his light

On hedge-row blossom, snowy white, Though nothèn yet did come in zight, A-stirrèn on the straỹèn stream;

Till, out by sheädy rocks there show'd A bwoat along his foamy road,

Wi' thik feäir maïd at mill, a-row'd that

Wi' Jeäne behind her brother's oars.

An' steätely as a queen o' vo'k,

She zot wi' floatèn scarlet cloak, folk An' comèn on, at ev'ry stroke,

Between my withy-sheäded shores.

willow-shaded

The broken stream did idly try

To show her sheäpe a-ridèn by,

The rushes brown-bloom'd stems did ply,

As if they bow'd to her by will.

The rings o' water, wi' a sock, sigh

Did break upon the mossy rock, An' gi'e my beätèn heart a shock, give Above my float's up-leapèn quill.

Then, lik' a cloud below the skies, A-drifted off, wi' less'nèn size, An' lost, she floated vrom my eyes,

Where down below the stream did wind; 
ðə b(w)uət

(h)wər kə:uz dıd slo:li siik ðə brınk

ə stə:uər dru: z^nbə:rnt gra:s tə drink

wi vifən flo:t ðət ðər did zink

ən rə:Iz ə:I zat əz in ə dri:m

ðə dazlən zın did kaist (h)Iz lə:ıt

pn hedzro: blpsəm sno:i (h)wəit

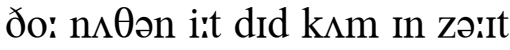

əstə:rən pn ठə stræIən stri:m

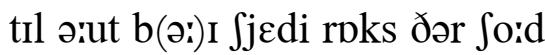

ə $\mathrm{b}(\mathrm{w})$ uət əlpy (h)Iz fo:mi ro:d

wi ðık fjeər mæid ət mil əro:d

wi dzjen bihə:In(d) (h)ər br^ðərz uərz

ən stjetli əz ə kwi:n ə vo:k

fi: zat wi flo:tən skarrlit klo:k

ən kımən pn ət evri stro:k

bitwi:n mə:I wıðijjedıd Juərz

ðə bro:kən stri:m did ə:Idli trə:I

to $\int o:(h)$ ər $\int j \varepsilon p$ ərə:Idən bə:I

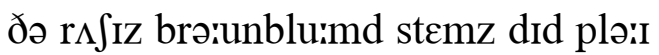

əz If ðe: bəiud to (h)ər b(ə:)I wil

ðə rijz ə wo:tər wi ə spk

did bre:k əppn ðə mpsi rok

ən gi: mə:I biətən ha:rt ə $\mathrm{pkk}$

əb $\Lambda \mathrm{V}$ mə:I flo:ts $\Lambda$ pli:pən kwil

ðعn lik ə klə:ud bilo: ðə skə:IZ

ədriftıd pf wi lesnən sə:Iz

ən lost fi: flo:tıd vrəm mə:I ə:IZ

(h)wər də:un bilo: ðə stri:m did wə:In(d) 
An' left the quiet weäves woonce mwore

once

To zink to rest, a sky-blue'd vloor,

Wi' all so still's the clote they bore,

yellow water-lily

Aye, all but my own ruffled mind. 
ən left ðə kwว:Iət wjevz (w)u:ns muər to zink to rest a skə:ibluid vluər wi a:l sə stilz ðə klo:t ðe: buər æI a:l bət mə:I o:n r $\Lambda$ fəld mə:In(d) 
An' there the brook, a-windèn round

The parrick zide, do run below

paddock

The grey-stwon'd bridge wi' gurglèn sound,

A-sheäded by the arches' bow;

span

Where former days the wold brown meäre,

Wi' father on her back, did wear

Wi' heavy shoes the grav'ly leäne, lane

An' sheäke her meäne o' yollor heäir.

An' many zummers there ha' glow'd,

To shrink the brook in bubblèn shoals,

An' warm the doust upon the road,

Below the trav'ller's burnèn zoles.

An' zome ha' zent us to our bed

In grief, an' zome in jaÿ ha' vled;

joy, flown

But vew ha' come wi' happier light

few

Than what's now bright, above our head.

The brook did peärt, zome years agoo,

Our Grenley meäds vrom Knapton's Ridge;

But now you know, between the two,

A road's a-meäde by Grenley Bridge. 
ðə pljes ə:uər o:n əgjen

wel $\theta a \eta k s$ tə ju: mə: fær

sə wərksəm wi jər hed ən han(d)

wi: sjevd in $\wedge$ to get əgjen

mə:I pu(:)ər vuərfe:ðərz plpt ə lan(d)

twər fpli lpst ən kınən gpt

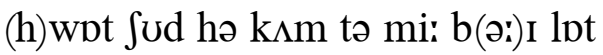

bət let ðat gu: tız wel ðə lan(d)

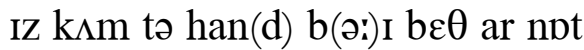

ən ðər ðə bruk əwə:In(d)ən rə:un(d)

ðə parık zə:Id də r $\Lambda$ n bilo:

ðə gre:stuənd brıdz wi gə:rglən sə:un(d)

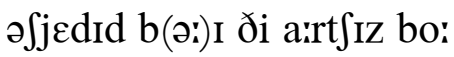

(h)wər fa:rmər de:z ðə (w)uəld brə:un mjeər

wi fe:ðər pn (h)ər bak did weər

wi hevi Ju:z ðə gravli ljen

ən $\int j \varepsilon k$ (h)ər mjen ə jalər hjeər

ən meni zımərz ðعər hə glo:d

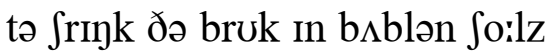
ən wa:rm ðə də:ust əppn ðə ro:d bilo: ðə travlərz bə:rnən zo:lz ən z^m ha zent əs tu ə:uər bed In griff ən $\mathrm{z} \Lambda \mathrm{m}$ in $\mathrm{d} z æ i$ ha vled bət vju: ha k^m wi hapiər lə:It ðən (h)wpts nə:u brə:It əbムv ə:uər hed

ðə bruk did pja:rt zım jiərz əgu: ə:uər grenli miədz vrəm naptənz $\mathrm{r} \Lambda \mathrm{d} 3$ bət nə:u jə no: bitwi:n ðə tu: ə ro:dz əmjed b(ə:)I grenli br $\Lambda d_{3}$ 
Zoo why should we shrink back at zight

Ov hindrances we ought to slight?

A hearty will, wi' God our friend,

Will gaïn its end, if 'tis but right. 


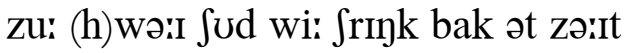

əv hindrənsız wi: oit to slə:It

ə hairti wil wi gnd əruər fren(d) wil gæin its $\varepsilon n(d)$ If tiz bət rə:It 
ECLOGUE

John an' Thomas

\section{THOMAS}

How b'ye, then, John, to-night; an' how

Be times a-waggèn on w' ye now?

I can't help slackenèn my peäce

moving

pace

When I do come along your pleäce,

To zee what crops your bit o' groun'

Do bear ye all the zummer roun'.

'Tis true you don't get fruit nor blooth,

blossom

'Ithin the glassèn houses' lewth;

But if a man can rear a crop

shelter of a greenhouse

grow (raise)

Where win' do blow an' rain can drop,

Do seem to come, below your hand,

As fine as any in the land.

\section{JOHN}

Well, there, the geärden stuff an' flow'rs

Don't leäve me many idle hours;

But still, though I mid plant or zow,

'Tis Woone above do meäke it grow.

\section{THOMAS}

Aye, aye, that's true, but still your strip

O' groun' do show good workmanship:

You've onions there nine inches round,

An' turmits that would waigh a pound;

An' cabbage wi' its hard white head,

An' teäties in their dousty bed, 
عklpg

dzan on twmos

THOMAS

hə:u bji: ðعn dzan tənə:It ən hə:u

bi: tə:Imz əwagən pn wji: nə:u

ə:I ke:nt help slakənən mə:I pjes

(h)wen ə:I də kım əlpy ju(:)ər pljes

to zi: (h)wpt krops jər bit a grə:un

də beər i: a:l ðə z^mər rə:un

tIz tru: jə do:nt get fru:t nər blui $\theta$

ıðın ðə glaisən hə:usız lu: $\theta$

bət If ə man kən reər ə krpp

(h)wər win də blo: ən ræIn kən drap

də si(:)m tə kım bilo: ju(:)ər han(d)

əz fə:In əz عni In ðə lan(d)

JOHN

wel ðعər ðə gja:rdən st $\Lambda$ f ən flə:uərz

do:nt liəv mi: meni ə:Idəl ə:uərz

bət stil ðo: ə:I mid ple:nt ər zo:

tIz (w)uin əb $\Lambda \mathrm{v}$ də mjek it gro:

THOMAS

æI æI ðats tru: bət stıl ju(:)ər strıp

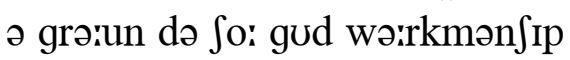
jəv ə:Inənz ðər nə:In int $\int \mathrm{Iz}$ rə:un(d) ən tə:rmits dət wud wæi ə pərun(d) ən kabidz wi its ha:rd (h)wə:It hed ən tjetiz In ðər dərusti bed 
An' carrots big an' straïght enough

Vor any show o' geärden stuff;

An' trees ov apples, red-skinn'd balls,

An' purple plums upon the walls,

An' peas an' beäns; bezides a store

O' heärbs vor ev'ry païn an' zore.

\section{JOHN}

An' over hedge the win's a-heärd,

A-ruslèn drough my barley's beard;

through

An' swaÿen wheat do overspread

Zix ridges in a sheet o' red;

An' then there's woone thing I do call

one

The girtest handiness ov all:

greatest

My ground is here at hand, avore

My eyes, as I do stand at door;

An' zoo I've never any need

so

To goo a mile to pull a weed.

\section{THOMAS}

No, sure, a miël shoulden stratch

Between woone's geärden an' woone's hatch.

A man would like his house to stand

Bezide his little bit o' land.

\section{JOHN}

Ees. When woone's groun' vor geärden stuff

Is roun' below the house's ruf

Then woone can spend upon woone's land

Odd minutes that mid lie on hand, 
ən karəts big ən stræit in $\Lambda f$

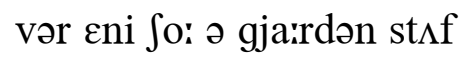
ən tri:z əv apəlz redskind ba:lz ən pərrpəl pl $\Lambda \mathrm{mz}$ əppn ðə wa:lz ən pi:z ən biənz bizə:Idz ə stuər ə ja:rbz vər عvri pæin ən zuər

\section{JOHN}

ən ə:vər hed3 ðə winz əhiərd ərıslən dru: mə:I ba:rliz biərd ən swæiən (h)wi:t du ə:vərspred zIks r $\Lambda$ dzIZ In ə fiit a red ən ðعn ðərz (w)u:n ðın ə:I də ka:l ðə gə:rtıst handinis əv ail mə:I grə:un(d) Iz hiər ət han(d) əvuər mə:I ə:IZ əz ə:I də $\operatorname{stan}(\mathrm{d})$ ət duər ən zu: ə:Iv nevər eni ni:d to gu: a mə:il to pul a wi:d

\section{THOMAS}

no: $\int \mathrm{u}(:) \partial r$ ə mə:iəl $\int u d ə n$ strat bitwi:n (w)u:nz gja:rdən ən (w)u:nz hat ə man wud lə:ık (h)Iz hə:us tə $\operatorname{stan}(\mathrm{d})$ bizə:Id (h)Iz litəl bit ə lan(d)

\section{JOHN}

i:s (h)wen (w)u:nz grə:un vər gja:rdən st $\Lambda f$ IZ rə:un bilo: ðə hə:usız $\mathrm{r} \Lambda \mathrm{f}$ ðદn (w)u:n kən spen(d) əppn (w)u:nz lan(d) pd minits ðət mid lə:I pn han(d) 
The while, wi' night a'comèn on,

The red west sky's a-wearèn wan;

Or while woone's wife, wi' busy hands,

Avore her vier o' burnèn brands,

Do put, as best she can avword,

Her bit o' dinner on the bwoard.

table

An' here, when I do teäke my road,

At breakfast-time, agwaïn abrode,

Why, I can zee if any plot

O' groun' do want a hand or not;

An' bid my childern, when there's need,

To draw a reäke or pull a weed,

Or heal young beäns or peas in line,

cover

Or tie em up wi' rods an' twine,

Or peel a kindly withy white

wooden stake

To hold a droopèn flow'r upright.

\section{THOMAS}

No. Bits o' time can zeldom come

To much on groun' a mile vrom hwome.

A man at hwome should have in view

The jobs his childern's hands can do;

An' groun' abrode mid teäke em all

Beyond their mother's zight an' call,

To get a zoakèn in a storm,

Or vall, i' may be, into harm.

\section{JOHN}

Ees. Geärden groun', as I've a-zed,

Is better near woone's bwoard an' bed. 
ðə (h)wə:Il wi nə:It əkımən pn

ðə red west skə:Iz əweərən wpn

ar (h)wə:Il (w)u:nz wə:If wi bizi han(d)z

əvuər (h)ər və:ıər ə bə:rnən bran (d)z

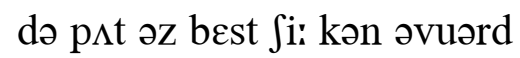

(h)ər bit ə dinər pn ðə buərd

ən hiər (h)wen ə:I də tjek mə:I ro:d

ət brekfəst tə:Im əgwæin əbro:d

(h)Wə: ə: ‘ kən zi: If عni plpt

ə grə:un də wpnt ə han(d) ər npt

ən bid mə:I t $t$ Ildərn (h)wen ðərz ni:d

to dre: ə rjek or pul ə wi:d

ar hi:l j^y biənz ər pi:z In lə:In

ar tə:I əm $\Lambda p$ wi rodz ən twə:In

ar pi:l ə kə:In(d)li wıði (h)wə:It

to huəld ə dru:pən flə:uər $\Lambda$ prəit

\section{THOMAS}

no: bits ə tə:Im kən zeldəm k^m

to $\mathrm{m} \Lambda \mathrm{t} \int \mathrm{ph}$ grə:un ə mə:Il vrəm huəm

ə man ət huəm Sud hav in vju:

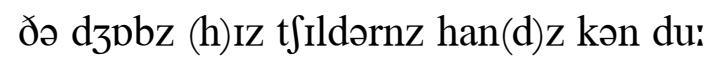

ən grə:un əbro:d mid tjek əm a:l

bijand ðər m^ðərz zə:It ən ka:l

to get a zo:kən In ə sta:rm

ar va:l I mæi bi: intə ha:rm

JOHN

iss gja:rdən grə:un əz ə:IV əzદd

Iz betər niər (w)u:nz buərd ən bed 
PENTRIDGE BY THE RIVER

PENTRIDGE!—oh! my heart's a-zwellèn

Vull o' jaÿ wi' vo'k a-tellèn joy, folk

Any news o' thik wold pleäce, that old

An' the boughy hedges round it,

An' the river that do bound it

Wi' his dark but glis'nèn feäce.

Vor there's noo land, on either hand,

To me lik' Pentridge by the river.

Be there any leaves to quiver

On the aspen by the river?

Doo he sheäde the water still,

Where the rushes be a-growèn,

Where the sullen Stour's a-flowèn

Drough the meäds vrom mill to mill? through Vor if a tree wer dear to me,

Oh! 'twer thik aspen by the river.

There, in eegrass new a-shootèn, I did run on even vootèn,

grass regrowing after mowing

Happy, over new-mow'd land;

footing

Or did zing wi' zingèn drushes

thrushes

While I plaïted, out o’ rushes,

Little baskets vor my hand;

Bezide the clote that there did float, yellow water-lily

Wi' yollow blossoms, on the river.

When the western zun's a vallèn,

What sh'ill vaïce is now a-callèn falling

Hwome the deäiry to the pails;

clear

Who do dreve em on, a-flingèn

dairy-cows

Wide-bow'd horns, or slowly zwingèn

drive

Right an' left their tufty tails?

curved 
pentrıd3 b(ə:)I ðə rIVər

pentrId3 o: mə:I ha:rts əzwelən

vul ə dzæi wi vo:k ətદlən

عni nju:z ə ðık (w)uəld pljes

ən ðə bə:ui hedzIz rə:un(d) it

ən ठə rivər ठət də bə:un(d) It

wi (h)Iz da:rk bət glisnən fjes

var ðərz nu: lan(d) pn ə:ıðər han(d)

tə mi: lik pentrıd3 b(ə:)I ठə rivər

bi: ðər عni liivz to kwıvər

pn ði aspən b(ə:)I ðə rIvər

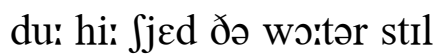

(h)wər ðə r $\Lambda \int \mathrm{Iz}$ bi: əgro:ən

(h)wər ðə sムlən stə:uərz əflo:ən

dru: ðə miədz vrəm mil tə mil

var If ə tri: wər diər to mi:

o: twər ðık aspən b(ə:)I ðə rıvər

ðər In i:gra:s nju: əృutən

ə:I did rın pn iivən vutən

hapi o:vər nju: mo:d lan(d)

ar did zin wi zingən $\operatorname{dr} \Lambda \int \mathrm{Iz}$

(h)wə:Il ə:I plæitıd ə'ut ə $\mathrm{r} \Lambda \int \mathrm{Iz}$

litəl ba:skits vər mə:I han(d) bızə:Id ðə klo:t ðət ðər did flo:t

wi jalər blpsəmz pn ðə rIvər

(h)wعn ðə westərn z^nz əva:lən

(h)wpt $\int \mathrm{ll}$ væıs Iz nə:u əka:lən

huəm ðə djeəri tə ðə pæilz

hu: də dre:v əm pn əflinən

wə:Id bo:d ha:rnz ar slo:li zwinən

rə:It ən left ठər t $\Lambda f t i$ tæilz 
As they do goo a-huddled drough

through

The geäte a-leäden up vrom river.

Bleäded grass is now a-shootèn

Where the vloor wer woonce our vootèn, once, footing

While the hall wer still in pleäce.

Stwones be looser in the wallèn;

walls

Hollow trees be nearer vallèn;

falling

Ev'ry thing ha' chang'd its feäce.

But still the neäme do bide the seäme-

'Tis Pentridge-Pentridge by the river. 
az ðe: də gu: əhıdəld dru:

ðə gjet əliədən $\Lambda p$ vrəm rivər

bljedid gra:s IZ nə:u ə९utən

(h)wər ðə vluər wər (w)u:ns ə:uər vutən

(h)wə:Il ðə ha:l wər stıl in pljes

stuənz bi: lu:sər in ðə wa:lən

hplər tri:z bi: niərər vailən

$\varepsilon v$ ri dı刀 hə tfandzd Its fjes

bət stil ðə njem də bə:Id ðə sjem

tIz pentrId3 pentrId3 b(ə:)I ðə rIvər 
IN brown-leav'd Fall the wheat a-left

'Ithin its darksome bed,

Where all the creakèn roller's heft weight

Seal'd down its lowly head,

Sprung sheäkèn drough the crumblèn mwold,

Green-yollow, vrom below,

An' bent its bleädes, a-glitt'rèn cwold,

At last in winter snow.

Zoo luck betide

The upland zide,

Where wheat do wride,

spread

In corn-vields wide,

By crowns o' Do'set Downs, O.

An' while the screamèn bird-bwoy shook

Wi' little zun-burnt hand,

His clacker at the bright-wing'd rook,

About the zeeded land;

His meäster there did come an' stop

His bridle-champèn meäre, borse

Wi' thankvul heart, to zee his crop

A-comèn up so feäir.

As there awhile

By geäte or stile,

He gi'ed the chile

A cheerèn smile,

By crowns o' Do'set Downs, O.

At last, wi' eärs o' darksome red,

The yollow stalks did ply,

A-swaÿèn slow, so heavy 's lead,

In aïr a-blowèn by; 
(h)wi:t

In brə:unliivd fa:l ðə (h)wiit əleft IðIn Its da:rksəm bed

(h)wər a:l ðə krikkən ro:lərz heft

si:ld də:un its lo:li hed

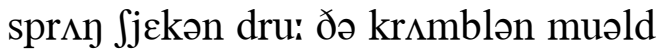

gri:njalər vrəm bilo:

ən bent its bljedz əglitrən kuəld

ot le:st in wintor sno:

zu: $1 \wedge \mathrm{k}$ bitə:Id

ði $\Lambda$ plən(d) zə:Id

(h)wər (h)wi:t də rə:Id

In ka:rnvi:l(d)s wə:Id

b(ə:)I krə:unz ə dpsət də:unz o:

ən (h)wə:Il ðə skri:mən bə:rdbwə:I Juk

wi litəl zınbərrnt han(d)

(h)Iz klakər ət ðə brə:Itwind ruk

əbə:ut ðə zi:did lan(d)

(h)Iz mja:stər ठər did k^m ən stpp

(h)Iz brə:Idəlt fampən mjeər

wi $\theta$ ankvul hart to zi: (h)Iz krpp

əkımən $\Lambda$ s sə fjeər

az ðər ə(h)wə:Il

b(ə:)I gjet ər stə:Il

hi: gi:d ðə t5ə:Il

a tfiərən smə:I

b(ə:)I krə氵unz ə dpsət də:unz o:

at le:st wi iərz ə da:rksəm red

ðə jalər ste:ks did plə:I

əswæıən slo: sə heviz led

In æIr əblo:ən bə:I 
An' then the busy reapers laid

In row their russlèn grips,

An' sheäves, a-leänèn head by head,

Did meäke the stitches tips.

Zoo food's a-vound, shocks (or stooks)

A-comèn round,

Vrom zeed in ground,

To sheaves a-bound,

By crowns o' Do'set Downs, O.

An' now the wheat, in lofty lwoads,

Above the meäres' broad backs, borses'

Do ride along the cracklèn rwoads,

Or dousty waggon-tracks.

An' there, mid every busy pick,

Ha' work enough to do;

An' where, avore, we built woone rick, so

Mid theäse year gi'e us two;

Wi' God our friend,

An' wealth to spend,

Vor zome good end,

That times mid mend,

In towns, an' Do'set Downs, O.

Zoo let the merry thatcher veel

Fine weather on his brow, As he, in happy work, do kneel

Up roun' the new-built mow, this, give

That now do zwell in sich a size,

An' rise to sich a height,

That, oh! the miller's wistful eyes

Do sparkle at the zight. 
ən ðعn ðə bızi ri:pərz led

In ro: ðər r $\Lambda$ slən grips

ən $\int i ə v z$ əliənən hed b(ə:)I hed

did mjek ðə stit $\int \mathrm{Iz}$ tips

zu: fudz əvə:un(d)

ək^mən rə:un(d)

vrəm zi:d in grə:un(d)

to $\int i \partial v z$ abərun $(\mathrm{d})$

b(ə:)I krə:unz ə dpsət də:unz o:

ən nə:u ðə (h)wi:t In lpfti luədz

əb $\Lambda \mathrm{v}$ ðə mjeərz bro:d baks

də rə:Id əlpy ðə kraklən ruədz

ar dərusti wagəntraks

ən ðər mıd عvri bızi pık

ha wərk in $\Lambda$ f to du:

ən (h)wər əvuər wi: bilt (w)uin rik

mId ðiəs jiər gi: əs tu:

wi gpd ə:uər fren(d)

ən wel $\theta$ tə $\operatorname{spcn}(\mathrm{d})$

vər zım gud $\varepsilon n(d)$

ðət tə:Imz mid mend

In tə:unz ən dosət də:unz o:

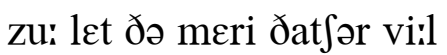

fə:In weðər pn (h)iz brə:u

əz hi: in hapi wə:rk do ni:l

$\Lambda$ p rə:un ðə nju:bilt mə:u

ðət nə:u də zwel in sit $\int$ ə sə:Iz

on rə:Iz to sitf a hə:It

ðət o: ðə milərz wistful ə:IZ

də spa:rkəl ət ðə zə:It 
An' long mid stand,

A happy band,

To till the land,

Wi' head an' hand,

By crowns o' Do'set Downs, O. 
ən lpy mid $\operatorname{stan}(\mathrm{d})$

ə hapi ban (d)

tə tIl ðə lan(d)

wi hed ən han(d)

b(ə:)I krə:unz ə dpsət dərunz o: 
AH! how the looks o' sky an' ground

Do change wi' months a-stealèn round,

When northern winds, by starry night,

Do stop in ice the river's flight;

Or brooks in winter raïns do zwell,

Lik' rollèn seas athirt the dell; across

Or trickle thin in zummer-tide,

Among the mossy stwones half dried;

But still, below the zun or moon,

The feärest vield's the meäd in June.

An' I must own, my heart do beät

Wi' pride avore my own blue geäte,

Where I can bid the steätely tree

Be cast, at langth, avore my knee;

An' clover red, an' deäzies feäir,

An' gil'cups wi' their yollow gleäre,

buttercups

Be all a-match'd avore my zight

By wheelèn buttervlees in flight,

butterflies

The while the burnèn zun at noon

Do sheen upon my meäd in June.

shine

An' there do zing the swingèn lark

So gaÿ's above the finest park,

An' day do sheäde my trees as true

As any steätely avenue;

An' show'ry clouds o' Spring do pass

To shed their rain on my young grass,

An' air do blow the whole day long,

To bring me breath, an' teäke my zong,

An' I do miss noo needvul boon

A-gi'ed to other meäds in June. 
ðə miəd in dzu:n

a: hə:u ðə luks ə skə:I ən grə:un(d)

də t $\int a n d 3$ wi m $\Lambda$ n $\theta$ s əstiilən rə:un(d)

(h)wen na:rðərn win(d)z b(ə:)I sta:ri nə:It

də stpp in ə:Is ðə rivərz flə:it

ar bruks in wintər ræInz də zwel

lik ro:lən si:z əðə:rt ðə del

ar trikəl ðIn In Zımərtə:Id

əmpy ðə mpsi stuənz he:f drə:Id

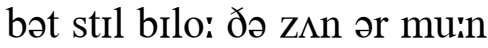

ðə fjeərıst vi:l(d)z ðə miəd In dzu:n

ən ə:I məst o:n mə:I ha:rt də bjət

wi prəild əvuər mə:I o:n blu: gjet

(h)wər ə:I kən bId ðə stjetli tri:

bi: ka:st ət $\operatorname{lay} \theta$ əvuər mə:I ni:

ən klo:vər red ən djeziz fjeər

ən gilkıps wi ðər jalər gljeər

bi: a:l əmatft əvuər mə:I zə:It

b(ə:)I (h)wi:lən bıtərvlizz In flə:It

ðə (h)wə:Il ðə bə:rnən zın ət nu:n

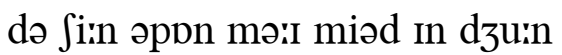

ən ðər də zın ðə swinən larrk

sə gæız əb $\Lambda$ v ðə fə:Inıst pa:rk

ən de: də $\int j \varepsilon d$ mə:I tri:z əz tru:

oz eni stjetli avənju:

ən Sə:uri klə'udz ə sprin də pais

tə $\int \varepsilon d$ ðər ræIn pn mə:I j $\wedge$ g gra:s

ən æIr də blo: ðə huəl de: lpy

to brin mi: bre $\theta$ ən tjek mə:I zpy

ən ə:I də mis nu: ni:dvol bu:n

əgi:d tu $\Lambda$ ðr miədz in dzu:n 
An' when the bloomèn rwose do ride

Upon the boughy hedge's zide,

We haymeäkers, in snow-white sleeves,

Do work in sheädes o' quiv'rèn leaves, shadows

In afternoon, a-liftèn high

Our reäkes avore the viery sky, fiery

A-reäken up the haÿ a-dried

By day, in lwongsome weäles, to bide ridges

In chilly dew below the moon,

O' shorten'd nights in zultry June.

An' there the brook do softly flow

Along, a-bendèn in a bow, curve An' vish, wi' zides o' zilver-white,

Do flash vrom shoals a dazzlèn light;

An' alders by the water's edge,

Do sheäde the ribbon-bleäded zedge, An' where, below the withy's head, willow's

The zwimmèn clote-leaves be a-spread, yellow water-lily

The angler is a-zot at noon seated

Upon the flow'ry bank in June.

Vor all the aiër that do bring

My little meäd the breath o' Spring,

By day an' night's a-flowèn wide

Above all other vields bezide;

Vor all the zun above my ground

'S a-zent vor all the naïghbours round,

An' rain do vall, an' streams do flow,

Vor lands above, an' lands below,

My bit o' meäd is God's own boon,

To me alwone, vrom June to June. 
ən (h)wen ðə blu:mən ruəz də rə:Id

әppn ðə bə:ui hedzız zə:Id

wi: hæImjekərz In sno:(h)wə:It sli:vz

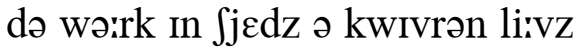

In E:tərnu:n əliftən hə:I

ə:uər rjєks əvuər ðə və:ıəri skə:I

ərjekən $\Lambda p$ ðə hæI ədrə:Id

b(ə:)I de: in lpysəm wjelz tə bə:Id

In t $\int$ Ili dju: bilo: ðə mu:n

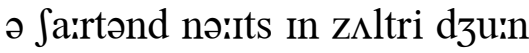

ən ðər ðə bruk də spf(t)li flo:

əlpy əbendən in ə bo:

ən vif wi zə:Idz ə zIlvər(h)wə:It

də flas vrəm fo:lz ə dazlən lə:It

ən a:ldərz b(ə:)I ðə wo:tərz $\varepsilon d 3$

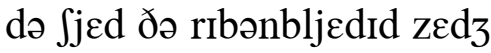

ən (h)wər bilo: ðə wiðiz hed

ðə zwımən klo:tli:vz bi: əspred

ði anglər Iz əzat ət nu:n

əppn ðə flə:uri bayk in dzu:n

var a:l ði æıər ðət də brın

mə:I litəl miəd ðə bre $\theta$ ə sprin

b(ə:)I de: ən nə:Its əflo:ən wə:Id

əb $\Lambda$ v a:l $\Lambda$ ðr vill(d)z bizə:Id

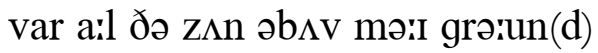

z əzent vər a:l ठə næibərz rə:un(d)

ən ræIn də vail ən stri:mz də flo:

vər $\operatorname{lan}(\mathrm{d}) \mathrm{z}$ əb $\Lambda \mathrm{v}$ ən $\operatorname{lan}(\mathrm{d}) \mathrm{z}$ bilo:

mə:I bit ə miəd Iz gpdz o:n bu:n

tə mi: əluən vrəm dzuin to dzuin 


\section{EARLY RISÈN}

THE aïr to gi'e your cheäks a hue give

O' rwosy red, so feaïr to view,

Is what do sheäke the grass-bleädes gray

At breäk o' day, in mornèn dew;

Vor vo'k that will be rathe abrode, folk, outside early

Will meet wi' health upon their road.

But bidèn up till dead o' night,

When han's o' clocks do stan' upright,

By candle-light, do soon consume

The feäce's bloom, an' turn it white.

An' light a-cast vrom midnight skies

Do blunt the sparklèn ov the eyes.

Vor health do weäke vrom nightly dreams

Below the mornèn's eärly beams,

An' leäve the dead-airr'd houses' eaves,

Vor quiv'rèn leaves, an' bubblèn streams,

A-glitt'rèn brightly to the view,

Below a sky o' cloudless blue. 
jə:rli rə:Izən

ði æIr tə gi: jər tfiəks ə hju:

ə ruəzi red sə fjeər to vju:

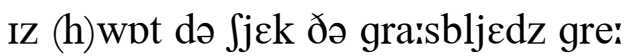

ət bre:k a de: in ma:rnon dju:

vər vo:k ðət wil bi: rjeð əbro:d

wil mi(:)t wi hel $\theta$ əppn ðər ro:d

bət bə:Idən $\Lambda p$ til ded ə nə:It

(h)wen hanz ə klpks də stan $\Lambda$ prə:It

b(ə:)I kandəl lə:It də suin kənsju:m

ðə fjesız blu:m ən tə:rn It (h)wə:It

ən lə:It əkaist vrəm midnə:It skə:Iz

də blınt ðə sparrklən əv ði ə:IZ

vər hel $\theta$ də wjek vrəm nə:Itli dri:mz

bılo: ðə ma:rnənz jərrli bi:mz

ən liəv ðə dedæIrd hə:usız i:vz

vər kwivrən liivz on bムblən stri:mz

aglitrən brə:itli to ðə vju:

bılo: ə skə:I ə klə:udlıs blu: 
WHY, his heart's lik' a popple, so hard as a stwone, pebble Vor 'tis money, an' money's his ho, concern An' to handle an' reckon it up vor his own,

Is the best o' the jaÿs he do know.

Why, vor money he'd gi'e up his lags an' be leäme,

Or would peärt wi' his zight an' be blind,

Or would lose vo'k's good will, vor to have a bad neäme, folk's

Or his peace, an' have trouble o' mind.

But wi' ev'ry good thing that his meänness mid bring,

might

He'd paÿ vor his money,

An' only zell honey to buy zome'hat sweet.

He did whisper to me, "You do know that you stood

By the Squier, wi' the vote that you had,

You could ax en to help ye to zome'hat as good, ask him

Or to vind a good pleäce vor your lad."

"Aye, aye, but if I wer beholdèn vor bread

To another," I zaid, "I should bind

All my body an' soul to the nod of his head,

An' gi'e up all my freedom o' mind."

An' then, if my païn wer a-zet wi' my gaïn,

I should paÿ vor my money,

An' only zell honey to buy zome'hat sweet.

Then, if my bit o' brook that do wind so vur round,

Wer but his, why, he'd straïghten his bed,

An' the wold stunpole woak that do stan' in my ground,

Shoudden long sheäde the grass wi' his head.

But if I do vind jaÿ where the leaves be a-shook

On the limbs, wi' their sheädes on the grass,

Or below, in the bow o' the withy-bound nook,

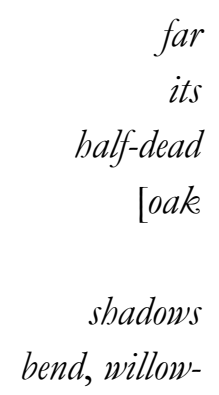

shadows bend, willow- 
zelən (w)u:nz hıni

to bə:I zımət swi(:)t

(h)wə:I (h)Iz ha:rts lik ə pppəl sə ha:rd əz ə stuən vor tız mıni ən mıniz (h)Iz ho:

ən tə handəl ən rekən it $\Lambda$ p vər (h)Iz o:n Iz ðə best ə ðə dzæIz hi: də no:

(h)wə:I vər $m \wedge n i$ hi:d gi: $\Lambda p$ (h)Iz lagz on bi: ljem ar wud pjarrt wi (h)Iz zə:It on bi: blə:in(d)

ar wud lu:z vo:ks gud wil vor to hav ə bad njem ar (h)Iz piss ən hav tr $\Lambda$ bəl ə mə:in(d)

bət wi عvri gud ðın ðət (h)Iz miənnıs mid brın

hi:d pæi vər (h)Iz mıni

ən o:nli zel hıni tə bə:I z^mət swi(:)t

ə did (h)wispər tə mi: ju: də no: ðət jə stud

b(ə:)I ðə skwə:Iər wi ðə vo:t ðət jə had ju: kud aiks ən to help i: to zımət əz gud

ar to və:in(d) ə gud pljes vər jər lad æI æI bət If ə:I wər bihuəldən vər bred

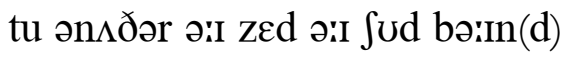
a:l mə:I bpdi ən so:l tə ðə npd əv (h)Iz hed

ən gi: $\Lambda p$ a:l mə:I fri:dəm ə mə:In(d)

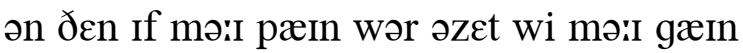
ว:I Jud pæi vər mə:I mıni ən o:nli zel hıni tə bə:I zımət swi(:)t

ðદn If mə:I bit ə bruk ðət də wə:In(d) sə və:r rə:un(d)

wər bət (h)Iz (h)wə:I hi:d stræitən (h)Iz bed ən ðə (w)uəld st $\Lambda$ npo:l (w)uək ðət də stan in mə:I grə:un(d)

Judən lpy Sjed ðə gra:s wi (h)Iz hed bət If ə:I də və:In(d) dzæI (h)wər ðə liivz bi: əfuk

pn ðə limz wi ðər $\int j \varepsilon d z$ pn ðə gra:s ar bilo: In ðə bo: ə ðə wıðibə:un(d) nuk 
That the rock-washèn water do pass,

Then wi' they jaÿs a-vled an' zome goold in their stead, flown

I should paÿ vor my money,

An' only zell honey to buy zome'hat sweet.

No, be my lot good work, wi' the lungs well in plaÿ,

An' good rest when the body do tire,

Vor the mind a good conscience, wi' hope or wi' jaÿ,

Vor the body, good lewth, an' good vire,

shelter

There's noo good o' goold, but to buy what 'ull meäke

Vor our happiness here among men;

An' who would gi'e happiness up vor the seäke

give

O’ zome money to buy it ageän?

Vor 'twould seem to the eyes ov a man that is wise,

Lik' money vor money,

Or zellèn woone's honey to buy zome'hat sweet. 


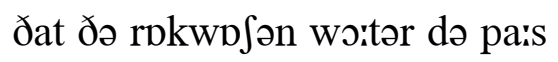

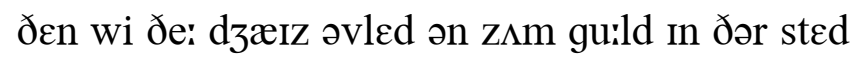

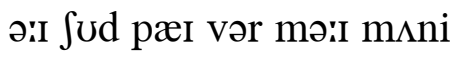

ən o:nli zel hıni tə bə:I zımət swi(:)t

no: bi: mə:I lpt gud wərrk wi ðə $1 \wedge \eta z$ wel in plæI ən gud rest (h)wen ðə bpdi də tə:ıər

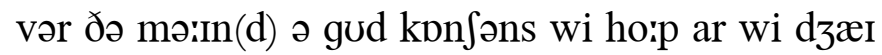

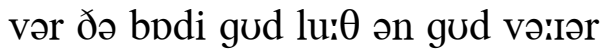
ðərz nu: gud ə gu:ld bət to bə:I (h)wpt ul mjek vər əruər hapinis hiər əmpy men ən hu: wud gi: hapinis $\Lambda$ p vər ðə sjek

ə $\mathrm{z} \wedge \mathrm{m}$ m^ni to bə:I It əgjen vər twud si(:)m tə ði ə:Iz əv ə man ðət IZ wə:IZ lik mıni vər mıni ar zelən (w)u:nz hıni tə bə:I zımət swi(:)t 
DOBBIN DEAD

Thomas (1) an' John (2) a-ta'èn o't.

talking about it

2. I do veel vor ye, Thomas, vor I be a-feär'd

You've a-lost your wold meäre then, by what I've a-heärd.

old borse

1. Ees, my meäre is a-gone, an' the cart's in the shed

Wi' his wheelbonds a-rustèn, an' I'm out o' bread;

yes

Vor what be my han's vor to eärn me a croust, its

Wi' noo meäre's vower legs vor to trample the doust.

crust

four, dust

2. Well, how did it happen? He vell vrom the brim

Ov a cliff as the teäle is, an' broke ev'ry lim'.

1. Why, I gi'ed en his run, an' he shook his wold meäne, An' he rambled a-veedèn in Westergap Leäne;

gave bim

An' there he must needs goo a-riggèn, an' crope

lane

Vor a vew bleädes o' grass up the wo'st o' the slope;

climbing, crept

Though I should ha' thought his wold head would ha' know'd

That vor stiff lags, lik' his, the best pleäce wer the road.

2. An' you hadden a-kept en so short, he must clim',

bim

Lik' a gwoat, vor a bleäde, at the risk ov a lim'.

1. Noo, but there, I'm a-twold, he did clim' an' did slide,

An' did screäpe, an' did slip, on the shelvèn bank-zide, few, worst

An' at langth lost his vootèn, an' roll'd vrom the top,

sloping

Down, thump, kick, an' higgledly, piggledly, flop.

footing

2. Dear me, that is bad! I do veel vor your loss,

Vor a vew years agoo, Thomas, I lost my ho'se.

horse 
dobin ded

tpməs (1.) ən dzan (2.) ətદ:ən o:t

2. ə:I də vi:l vər i: tpməs vər ə:I bi: əfiərd jəv əlpst jər (w)uəld mjeər ðعn b(ə:)I (h)wDt ə:IV əhiərd

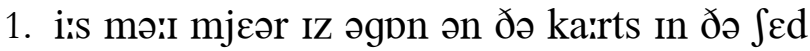

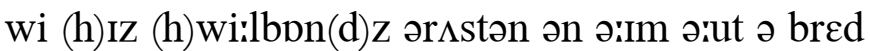
vər (h)wpt bi: mə:i hanz vər tə ja:rn mi: ə krə:ust wi nu: mjeərz və:uər lagz vər tə trampəl ðə də:ust

2. wel hə:u did it hapən ə vel vrəm ðə brim əv ə klıf az ðə tjel Iz ən bro:k عvri lim

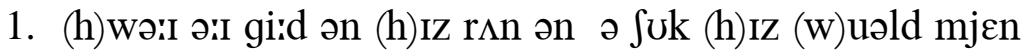
ən ə rambəld əvi:dən in westərgap ljen ən ðər ə məst ni:dz gu: ərıgən ən kro:p vər ə vju: bljedz ə gra:s $\Lambda$ р ðə w $\Lambda$ st ə ðə slo:p ðо: ə:I Jud hə ðэ:t (h)Iz (w)uəld hed wud hə no:d ðət vər stıf lagz lik (h)Iz ðə best pljes wər ðə ro:d

2. ən jə hadən əkept ən sə Ja:rt hi: məst klım lik ə guət vər ə bljed ət ðə risk əv ə lim

1. no: bət ðər ə:Im ətuəld hi: did klim ən did slə:Id ən did skrjep ən did slip pn ðə $\int \varepsilon l v ə n$ baykzə:Id ən ət lay $\theta$ lpst (h)Iz vutən ən ro:ld vrəm ðə top də:un $\theta \Lambda \mathrm{mp}$ kık ən hrgəldli prgəldli flpp

2. diər mi: ðat Iz bad ə:I də vi:l vər jər lps vər ə vju: jiərz əgu: tpməs ə:I lpst mə:I hps 
1. How wer't? If I heärd it, I now ha' vorgot;

Wer the poor thing bewitch'd or a-pweison'd, or what?

2. He wer out, an' a-meäkèn his way to the brink

O' the stream at the end o' Church Leäne, vor to drink;

lane

An' he met wi' zome yew-twigs the men had a-cast

Vrom the yew-tree, in churchyard, the road that he past.

He wer pweison'd. (1.) O dear, 'tis a hard loss to bear,

Vor a tranter's whole bread is a-lost wi' his meäre;

carrier's, horse

But ov all churches' yew-trees, I never zet eyes

On a tree that would come up to thik woone vor size.

that one

2. Noo, 'tis long years agone, but do linger as clear

In my mind though as if I'd a-heärd it to year.

this year

When King George wer in Do'set, an' show'd us his feäce

By our very own doors, at our very own pleäce,

That he look'd at thik yew-tree, an' nodded his head, An' he zaid,- - an' I'll tell ye the words that he zaid:-

"I'll be bound, if you'll sarch my dominions all drough, search, through

That you woon't vind the fellow to thik there wold yew." 
1. hə:u wə:rt If ə:I hiərd It ə:I nə:u hə vərgpt wər ðə pu(:)ər ðı biwitft ar əpwə:Izənd ər (h)wpt

2. hi: wər ərut ən əmjekən (h)Iz we: tə ðə brıjk

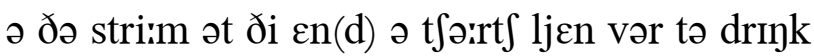
ən hi: met wi zəm juitwigz ðə men had əkaist

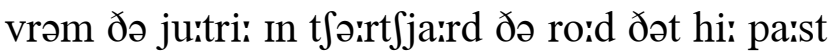
hi: wər pwə:Izənd (1.) o: diər tIz ə hard los to beər vər ə trantərz huəl bred Iz əlpst wi (h)Iz mjeər

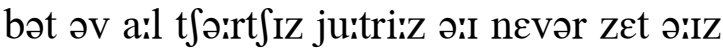
pn ə tri: ðət wud kım $\Lambda$ p tə ðIk (w)u:n vər sə:IZ

2. no: tIz lin jiərz əginn bət də lingər əz kliər In mə:I mə:In(d) ðo: əz If ə:Id əhiərd it to jiər (h)wen kın dza:rdz wər in dosət ən Jo:d əs (h)Iz fjes b(ə:)I ə:uər veri o:n duərz ət ə:uər veri o:n pljes ðət ə lukt ət ðık ju:tri: ən npdid (h)Iz hed ən ə zed ən ə:Il tel i: ðə wə:rdz ðət ə zed ə:Il bi: bə:un(d) If jəl sairt $\int$ məi dəminjənz ail dru: ðət jə wu(:)nt və:In(d) ðə felər tə ðık ðعər (w)uəld ju: 


\section{HAPPINESS}

AH! you do seem to think the ground,

Where happiness is best a-vound,

Is where the high-peäl'd park do reach

-fenced

Wi' elem-rows, or clumps o' beech;

Or where the coach do stand avore

The twelve-tunn'd house's lofty door,

chimneyed

Or men can ride behin' their hounds

Vor miles athirt their own wide grounds,

across

An' seldom wi' the lowly;

Upon the green that we do tread,

Below the welsh-nut's wide-limb'd head,

walnut's

Or grass where apple trees do spread?

No, so's; no, no: not high nor low:

souls (friends)

'Tis where the heart is holy.

'Tis true its veet mid tread the vloor,

may

'Ithin the marble-pillar'd door,

Where day do cast, in high-ruf'd halls,

-roofed

His light drough lofty window'd walls;

through

An' wax-white han's do never tire

Wi' strokes ov heavy work vor hire,

An' all that money can avword

Do lwoad the zilver-brighten'd bwoard;

table

Or mid be wi' the lowly,

Where turf's a-smwolderèn avore

The back, to warm the stwonèn vloor,

stone

An' love's at hwome 'ithin the door?

No, so's; no, no; not high nor low:

'Tis where the heart is holy.

An' ceäre can come 'ithin a ring

O' sworded guards, to smite a king, 
hapinis

a: ju: də si(:)m tə ðıңk ðə grə:un(d)

(h)wər hapinis iz best əvə:un(d)

IZ (h)wər ðə hə:Ipjeld pa:rk də ritts

wi عləmro:z ər klımps ə biits

ar (h)wər ðə ko:t $\int$ də stan(d) əvuər

ðə twelvtınd hə:usız lpfti duər

ar men kən rə:Id bihə:In ðər hə:un(d)z

vər mə:Ilz əðə:rt ðər o:n wə:Id grə:un(d)z

ən scldəm wi ðə lo:li

əppn ðə griin ðət wi: də tred

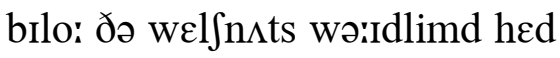

ar gra:s (h)wər apəl tri:z də spred

no: so:z no: no: not hə:I nar lo:

tIz (h)wər ðə ha:rt Iz ho:li

tIz tru: its vi:t mId tred ðə vluər

ıðın ðə ma:rbəlpılərd duər

(h)wər de: də ka:st in hə:Ir $\Lambda \mathrm{ft}$ ha:lz

(h)Iz lə:It dru: lpfti windərd wa:lz

ən waks(h)wə:It hanz də nevər tə:ıər

wi stro:ks əv hevi wərk vər hə:Iər

ən a:l ðət m^ni kən əvuərd

də luəd ðə zIlvərbrə:Itənd buərd

ar mId bi: wi ðə lo:li

(h)wər tə:rfs əsmuəldərən əvuər

ðə bak tə wa:rm ðə stuənən vluər

ən $1 \Lambda \mathrm{VZ}$ ət huəm IðIn ðə duər

no: so:z no: no: npt hə:I nar lo:

tız (h)wər ðə ha:rt Iz ho:li

ən kjeər kən kım ıðın ə rın

ə suərdid ga:rdz to sməit $ə$ kin 
Though he mid hold 'ithin his hands

The zwarmèn vo'k o' many lands;

swarming folk

Or goo in drough the iron-geäte

through

Avore the house o' lofty steäte;

Or reach the miser that do smile

A-buildèn up his goolden pile;

Or else mid smite the lowly, may That have noo pow'r to loose or bind Another's body, or his mind, But only hands to help mankind. If there is rest 'ithin the breast, 'Tis where the heart is holy. 
ðo: hi: mId huəld ıðın (h)Iz han(d)z

ðə zwa:rmən vo:k ə meni lan(d)z

ar gu: in dru: ðə ə:ıərngjet

əvuər ðə hə:us ə lpfti stjet

ar riit ðə mə:Izər ðət də smə:Il

əbildən $\Lambda$ p (h)Iz guildən pə:il

ar عls mid smə:it ðə lo:li

ðət hav nu: pə:uər tə luis ər bə:In(d)

ən^ðərz bpdi ər (h)Iz mə:In(d)

bət o:nli han(d)z tə help mankə:In(d)

If ðər IZ rest IðIn ðə brest

tIz (h)wər ðə ha:rt Iz ho:li 


\section{GRUFFMOODY GRIM}

AYE, a sad life his wife must ha' led,

Vor so snappish he's leätely a-come,

That there's nothèn but anger or dread

Where he is, abroad or at hwome;

He do wreak all his spite on the bwones

O' whatever do vlee, or do crawl;

He do quarrel wi' stocks, an' wi' stwones,

An' the rain, if do hold up or vall;

There is nothèn vrom mornèn till night

Do come right to Gruffmoody Grim.

Woone night, in his anger, he zwore one

At the vier, that didden burn free:

An' he het zome o't out on the vloor,

Vor a vlanker it cast on his knee.

Then he kicked it vor burnèn the child,

An' het it among the cat's heaïrs;

An' then beät the cat, a-run wild,

Wi' a spark on her back up the steaïrs:

Vor even the vier an' fleäme

Be to bleäme wi' Gruffmoody Grim.

Then he snarl'd at the tea in his cup,

Vor 'twer all a-got cwold in the pot,

But 'twer woo'se when his wife vill'd it up

worse

Vrom the vier, vor 'twer then scaldèn hot;

Then he growl'd that the bread wer sich stuff

As noo hammer in parish could crack,

An' flung down the knife in a huff;

Vor the edge o'n wer thicker'n the back.

Vor beäkers an' meäkers o' tools

Be all fools wi' Gruffmoody Grim. 
grıfmudi grım

æI ə sad lə:If (h)IZ wə:If mıst hə led vər so: snapis hi:z ljetli əkım

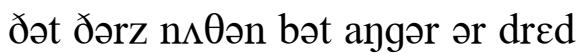
(h)wər hi: Iz əbro:d ər ət huəm hi: də ri:k a:l (h)Iz spə:It pn ठə buənz ə (h)wptevər də vli: ar də kra:l hi: də kwarəl wi stpks ən wi stuənz ən ðə ræIn If də huəld $\Lambda$ p ər va:l ðər Iz n $\Lambda \theta ə n$ vrəm ma:rnən til nə:it də kım rə:It tə grıfmudi grim (w)u:n nə:It In (h)Iz aygər ə zwuər ət ðə və:ıər ðət didən bə:rn fri:

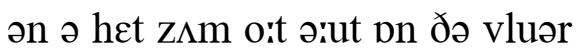
vər ə vlaykər it ka:st pn (h)Iz ni:

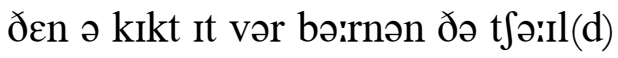
ən het It əmpy ðə kats hjeərz ən ðعn biət ðə kat ər $\Lambda$ w wə:Il(d) wi ə spa:rk pn (h)ər bak $\Lambda$ д ðə stjeərz var iivən ðə və:ıər ən fljem bi: to bljem wi grafmudi grim

ðعn ə sna:rld ət ðə te: in (h)Iz kıp var twər a:l əgpt kuəld in ðə ppt bət twər wu:s (h)wen (h)Iz wə:If vild it $\Lambda$ p vrəm ðə və:ıər var twər ðعn ska:ldən hpt

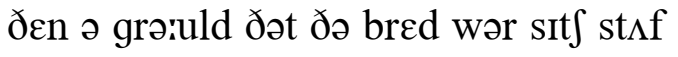
əz nu: hamər in paris kud krak ən flıy də:un ðə nə:If in ə $\mathrm{h} \Lambda \mathrm{f}$ vər ði $\varepsilon d 3$ pn wər $\theta$ Ikərn ðə bak vər bjekərz ən mjekərz ə tuilz bi: a:l fu:lz wi gr $\wedge$ fmudi grim 
Oone day as he vish'd at the brook,

He flung up, wi' a quick-handed knack,

His long line, an' his high-vleèn hook

-flying

Wer a-hitch'd in zome briars at his back.

Then he zwore at the brembles, an' prick'd

His beäre hand, as he pull'd the hook free;

bare

An' ageän, in a rage, as he kick'd

At the briars, wer a-scratch'd on the knee.

An' he wish'd ev'ry bremble an' briar

Wer o' vier, did Gruffmoody Grim.

on fire

Oh! he's welcome, vor me, to breed dread

Wherever his sheäde mid alight,

An' to live wi' noo me'th round his head,

shadow may

mirth

An' noo feäce wi' a smile in his zight;

But let vo'k be all merry an' zing folk

At the he'th where my own logs do burn, bearth

An' let anger's wild vist never swing

In where I have a door on his durn;

its doorpost

Vor I'll be a happier man,

While I can, than Gruffmoody Grim.

To zit down by the vier at night,

Is my jaÿ—vor I woon't call it pride,-

Wi' a brand on the bricks, all alight, An' a pile o' zome mwore at the zide.

Then tell me o' zome'hat that's droll, An' I'll laugh till my two zides do eäche

Or o' naighbours in sorrow o' soul, An' I'll tweil all the night vor their seäke;

An' show that to teäke things amiss

Idden bliss, to Gruffmoody Grim. 
(w)uin de: əz ə vift ət ðə bruk ə flıy $\Lambda p$ wi ə kwıkhandid nak (h)Iz loy lə:In ən (h)Iz hər:vli:ən huk wər əhitft in zəm brəIərz ət (h)Iz bak ðعn ə zwuər ət ðə brembəlz ən prikt (h)Iz bjeər han(d) əz ə puld ðə huk fri: ən əgjen in $ə$ re:dz $\partial \mathrm{z}$ ə kıkt ət ðə brəIəərz wər əskratft pn ðə ni: ən ə wift $\varepsilon v r i$ brembəl ən brər:ər wər ə və:ıər did grıfmudi grim

o: hi:z welkəm vər mi: to bri:d dred (h)wərevər (h)Iz Jjed mid ələ:It ən tə liv wi nu: $m \varepsilon \theta$ rə:un(d) (h) Iz hed ən nu: fjes wi ə smə:Il in (h)Iz zə:It bot let vo:k bi: a:l meri on zIn ət ðə he $\theta$ (h)wər mə:I o:n lpgz də bə:rn ən let aygərz wə:Il(d) vist nevər swin In (h)wər əII həv ə duər pn (h)Iz də:rn var əill bi: ə hapiər man (h)wə:ıl ə:ı kan ðən gr $\Lambda$ fmudi grım

tə zit də:un b(ə:)I ðə və:ıər ət nə:It IZ mə:I dzæi var ə:I wu(:)nt ka:l It prə:Id wi ə bran(d) pn ðə briks a:l ələ:It ən ə pə:Il ə zəm muər ət ठə zə:Id

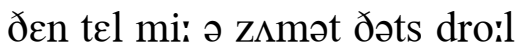
ən ə:Il le:f til mə:I tu: zə:Idz də jek ar ə næibərz In sarə(r) ə so:1 ən ə:Il twə:Il a:l ðə nə:It vər ðər sjek ən fo: ðət tə tjek ðInz əmIs Idən blis to gr $\Lambda$ fmudi grim 
An' then let my child clim' my lag,

Or my maïd come an' coax me to bag

Vor a frock, an' a frock she shall win;

Or, then if my wife do meäke light

O' whatever the bwoys mid ha' broke,

It wull seem but so small in my zight,

As a leaf a-het down vrom a woak

bit, oak

An' not meäke me ceäper an' froth

caper

Vull o' wrath, lik' Gruffmoody Grim. 


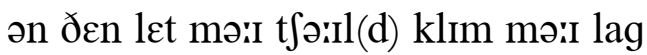
ən ə:Il lift ən wi $1 \Lambda \mathrm{V}$ tə mə:I $t \int \mathrm{In}$ ar mə:I mæId kım ən ko:ks mi: to bag vər ə frok ən ə frok Ji: Jəl win ar ðદn If mə:I wə:If də mjek lə:It ə (h)wptevər ðə bwə:Iz mid hə bro:k It wul si(:)m bət sə sma:l In mə:I zə:It əz ə lisf əhદt də:un vrəm ə (w)uək ən not mjek mi: kjepər ən fro $\theta$ vul ə ro $\theta$ lik gr $\Lambda$ fmudi grim 
O THE wings o' the rook wer a-glitterèn bright, As he wheel'd on above, in the zun's evenèn light, An' noo snow wer a-left, but in patches o' white,

On the hill at the turn o' the days.

An' along on the slope wer the beäre-timber'd copse, bare-

Wi' the dry wood a-sheäkèn, wi' red-twiggèd tops.

Vor the dry-flowèn wind, had a-blow'd off the drops

O' the rain, at the turn o' the days.

There the stream did run on, in the sheäde o' the hill, So smooth in his flowèn, as if he stood still, An' bright wi' the skylight, did slide to the mill,

By the meäds, at the turn o' the days.

An' up by the copse, down along the hill brow,

Wer vurrows a-cut down, by men out at plough, So straight as the zunbeams, a-shot drough the bough through

O' the tree at the turn o' the days.

Then the boomèn wold clock in the tower did mark old His vive hours, avore the cool evenèn wer dark, An' ivy did glitter a-clung round the bark

O' the tree, at the turn o' the days.

An' womèn a-fraid o' the road in the night,

Wer a-heästenèn on to reach hwome by the light, A-castèn long sheädes on the road, a-dried white, shadows

Down the hill, at the turn o' the days.

The father an' mother did walk out to view

The moss-bedded snow-drop, a-sprung in the lew, shelter An' hear if the birds wer a-zingèn anew,

In the boughs, at the turn o' the days. 
ðə tə:rn ə ðə de:z

o: ðə winz ə ðə ruk wər əglitərən brə:It

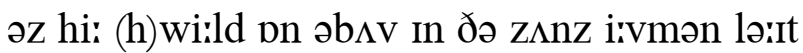
ən nu: sno: wər əleft bət in patfiz ə (h)wərit pn ðə hil ət ðə tə:rn ə ðə de:z ən əlpy pn ðə slo:p wər ðə bjeərtımbərd kpps

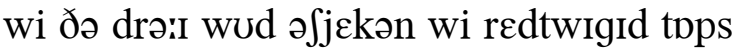
vər ðə drə:Iflo:ən win(d) had əblo:d pf ðə draps

ə ðə ræIn ət ðə tə:rn ə ठə de:z

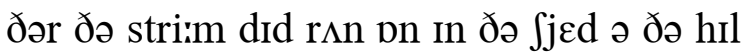
sə smu:ð in (h)IZ flo:ən əZ If ə stud strl ən brə:It wi ðə skə:Ilə:It did slə:Id tə ðə mil

b(ә:)I ðə miədz ət ðə tə:rn ə ðə de:z ən $\Lambda$ p b(ə:)I ðə kpps də:un əlpy ðə hıl brə:u

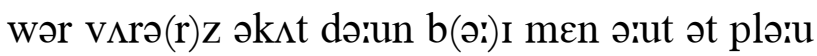
sə stræit əz ðə zムnbi:mz əshpt dru: ðə bə:u ə ðə tri: ət ðə tə:rn ə ðə de:Z

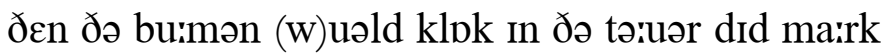
(h)IZ vəIIv ə:uərz əvuər ðə ku:l i:vmən wər da:rk

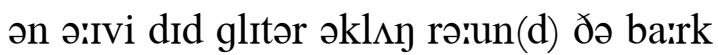

ə ðə tri: ət ðə tə:rn ə ðə de:Z ən wumın əfræId ə ðə ro:d In ðə nə:It wər əhjesənən pn tə ritt huəm b(ə:)I ठə lə:It əka:stən loy $\int j \varepsilon d z$ pn ðə ro:d ədrə:Id (h)wə:It də:un ðə hil ət ðə tə:rn ə ðə de:Z

ðə fє:ðər ən m^ðər did we:k ə:ut tə vju: ðə mpsbedid sno:drap əspr $\wedge$ In ðə lu: ən hiər If ðə bə:rdz wər əzIngən ənju: In ðə bə:uz ət ðə tə:rn ə ðə de:z 
An' young vo'k a-laughèn wi' smooth glossy feäce,

folk

Did hie over vields, wi' a light-vooted peäce,

burry, pace

To friends where the tow'r did betoken a pleäce

Among trees, at the turn o' the days. 
ən j $\wedge$ y vo:k əle:fən wi smu:ð glpsi fjes

did hə:I o:vər vi:l(d)z wi ə lə:itvutid pjes

tə $\operatorname{fren}(\mathrm{d}) \mathrm{z}(\mathrm{h})$ wər ðə tə:uər did bito:kən ə pljes

əmpy tri:z ət ðə tə:rn ə ðə de:z 
LAST night the merry farmers' sons,

Vrom biggest down to leäst, min, mate

Gi'ed in the work of all their guns, gave An' had their sparrow feäst, min.

An' who vor woone good merry soul one

Should goo to sheäre their me'th, min, mirth

But Gammon Gaÿ, a chap so droll, He'd meäke ye laugh to death, min.

Vor heads o' sparrows they've a-shot They'll have a prize in cwein, min, That is, if they can meäke their scot, coin Or else they'll paÿ a fine, min. An' all the money they can teäke

'S a-gather'd up there-right, min, An' spent in meat an' drink, to meäke A supper vor the night, min.

Zoo when they took away the cloth,

In middle of their din, min, An' cups o' eäle begun to froth, ale

Below their merry chin, min, An' when the zong, by turn or chaïce,

Went roun' vrom tongue to tongue, min, Then Gammon pitch'd his merry vaïce, An' here's the zong he zung, min.

Zong.

If you'll but let your clackers rest tongues Vrom jabberèn an' hootèn, I'll teäke my turn, an' do my best,

To zing o' sparrow shootèn. 
ðə $\operatorname{sparə(r)~kl\Lambda b}$

le:st nə:It ðə meri fa:rmərz s $\mathrm{nz}$ vrəm bigist dəiun to liəst min

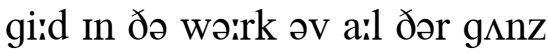
ən had ðər sparə(r) fiəst min ən hu: vər (w)u:n gud meri so:l

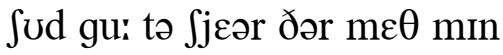
bət gamən gæı ə t $\int a p$ sə dro:l hi:d mjek i: le:f to de $\theta$ min

vər hedz ə sparə(r)z ðe:v əshpt ðe:l hav ə prə:Iz In kwə:In min ðat IZ If ðe: kən mjek ðər skpt ar عls ðe:l pæi ə fə:In min ən a:l ðə m^ni ðe: kən tjek $\mathrm{s}$ əgaðərd $\Lambda \mathrm{p}$ ðعər rə:It min ən spent In mi:t ən drıjk tə mjek ə sıpər vər ðə nə:It mIn

zu: (h)wen ðe: tuk əwə:I ðə klp $\theta$ In midəl əv ðər din min ən kıps ə jel big $\Lambda$ tə frp $\theta$ bilo: ठər meri t $\int \mathrm{In}$ min ən (h)wen ðə zpy b(ə:)I tə:rn ər tfæIS went rə:un vrom t $\Lambda$ y to t $\Lambda$ y min ðعn gamən pitft (h)IZ meri væIs әn hiərz ðə zpy ə z^y mIn

zDy

If jəl bət let jər klakərz rest vrəm dzabərən ən hutən ə:Il tjek mə:I tə:rn ən du: mə:I best to zIy ə sparə(r) Jutən 
Since every woone mus' pitch his key,

An' zing a zong, in coo'se, lads,

Why sparrow heads shall be to-day

The heads o' my discoo'se, lads.

discourse

We'll zend abroad our viery hail out, fiery

Till ev'ry foe's a-vled, lads, fled

An' though the rogues mid all turn tail, may

We'll quickly show their head, lads.

In corn, or out on oben ground,

In bush, or up in tree, lads,

If we don't kill em, I'll be bound,

We'll meäke their veathers vlee, lads.

Zoo let the belted spwortsmen brag

so

When they've a-won a neäme, so's, souls (friends)

That they do vind, or they do bag,

Zoo many head o' geäme, so's:

Vor when our cwein is woonce a-won, coin, once

By heads o' sundry sizes,

Why, who can slight what we've a-done?

We've all a-won head prizes.

Then teäke a drap vor harmless fun,

But not enough to quarrel;

Though where a man do like the gun,

He can't but need the barrel.

O' goodly feäre, avore we'll start, fare We'll zit an' teäke our vill, min;

Our supper-bill can be but short,

Tis but a sparrow-bill, ${ }^{4} \mathrm{~min}$.

\footnotetext{
${ }^{4}$ Sparrowbill: 'a small headless nail used in the soles of boots and shoes'; hence 'sparrowbill pie, anything unpalatable or unpleasant' (EDD, s.vv. Sparrable and Sparrowbill).
} 
sins evri (w)uin məs pit (h)Iz ke: ən zIy ə zpy In kuis ladz (h)wə:I sparə(r) hedz Jəl bi: təde: ðə hedz ə mə:I diskuis ladz

will zen(d) əbro:d ə'uər və:ıəri hæıl

tıl عvri fo:z əvled ladz әn ठо: ðə ro:gz mid a:l tə:rn tæil

will kwıkli fo: ðər hed ladz In ka:rn ar ə:ut pn o:bən grə:un(d) In bof ar $\Lambda \mathrm{p}$ in tri: ladz If wi: do:nt kil əm ə:Il bi: bə:un(d) wi:l mjek ðər veðərz vli: ladz

zu: let ðə beltıd spuərtsmən brag

(h)wen ðe:v əwın ə njem so:z ðət ðe: də və:In(d) ar ðe: də bag

zu: meni hed a gjem so:z $\operatorname{var}(\mathrm{h})$ wen ə:uər kwə:In Iz (w)u:ns əwın b(ə:)I hedz ə s $\Lambda$ ndri sə:IZIZ (h)wə:I hu: kən slə:It (h)wpt wiiv əd $\Lambda$ n wi:v a:l əwın hed prə:IzIz

ðદn tjek ə drap vər ha:rmlıs f $\wedge$ n bət npt in $\Lambda$ f to kwarəl

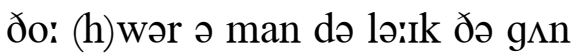
hi: ke:nt bət ni:d ðə barəl ə gudli fjeər əvuər will sta:rt wiil zit ən tjek ə:uər vil min ə:uər sıpərbil kən bi: bət farrt tIz but ə sparə(r)bil min 
OH! thik Gammony Gaÿ is so droll, that

That if he's at hwome by the he'th, bearth

Or wi' vo'k out o' door, he's the soul folk

O' the meetèn vor antics an' me'th; mirth

He do cast off the thoughts ov ill luck

As the water's a-shot vrom a duck;

He do zing where his naïghbours would cry-

He do laugh where the rest o's would sigh:

of us

Noo other's so merry o' feäce,

In the pleäce, as Gammony Gaÿ.

An' o’ workèn days, Oh! he do wear

Such a funny roun' hat,-you mid know'tmay

Wi' a brim all a-strout roun' his heäir,

An' his glissenèn eyes down below't;

An' a cwoat wi' broad skirts that do vlee

In the wind ov his walk, round his knee;

An' a peäir o' girt pockets lik' bags,

great

That do swing an' do bob at his lags:

While me'th do walk out drough the pleäce, through

In the feäce o' Gammony Gaÿ.

An' if he do goo over groun'

Wi' noo soul vor to greet wi' his words,

The feäce o'n do look up an' down, his face

An' round en so quick as a bird's;

bim

An' if he do vall in wi' vo'k,

Why, tidden vor want ov a joke,

'tisn't

If he don't zend em on vrom the pleäce

Wi' a smile or a grin on their feäce:

An' the young wi' the wold have a-heärd

old

A kind word vrom Gammony Gaÿ. 
gaməni gæi

o: ðık gaməni gæI IZ sə dro:1

ðət If hi:z ət huəm b(ə:)I ठə hع $\theta$

ar wi vo:k əiut ə duər hi:z ðə so:l

ə ðə mi:tən vər antıks ən $m \varepsilon \theta$

hi: də kaist pf ðə ðว:ts əv Il $1 \Lambda \mathrm{k}$

əz ðə wə:tərz əshpt vrəm ə $\mathrm{d} \Lambda \mathrm{k}$

hi: də zIy (h)wər (h)Iz næibərz wud krə:I

hi: də le:f (h)wər ðə rest o:s wud sə:I

nu: $\Lambda$ ðrz sə meri ə fjes

In ðə pljes əz gaməni gæı

an ə wərrkən de:z o: hi: də weər sit ə f $\wedge$ ni rə:un hat jə mid no:t wi ə brim ail əstrə:ut rə:un (h)ız hjeər ən (h)Iz glisənən ə:Iz də:un bilo:t ən ə kuət wi bro:d skərrts ðət də vli: In ठə $w \operatorname{In}(\mathrm{d})$ əv (h)IZ we:k rə:un(d) (h)Iz ni: ən ə pjeər ə gə:rt ppkits lik bagz ðət də swiy ən də bob ət (h)Iz lagz (h)wə:Il me $\theta$ də we:k ə:ut dru: ðə pljes In ðə ðə fjes ə gaməni gæI

ən If hi: də gu: o:vər grə:un wi nu: so:l vər to gri:t wi (h)Iz wərrdz ðə fjes o:n də luk $\Lambda$ p ən dərun ən rə:un(d) ən sə kwik əz ə bərrdz ən If hi: də va:l in wi vo:k (h)wə:I tIdən vər wpnt əv ə dzo:k If ə do:nt $z \varepsilon n(d)$ əm pn vrəm ðə pljes wi ə smə:Il ar ə grin pn ðər fjes ən ðə jムy wi ðə (w)uəld həv əhjə:rd ə kə:In(d) wə:rd vrəm gaməni gæI 
An' when he do whissel or hum,

'Ithout thinkèn o' what he's a-doèn,

He'll beät his own lags vor a drum,

An' bob his gaÿ head to the tuèn;

tune

An' then you mid zee, 'etween whiles,

may

His feäce all alive wi' his smiles,

An' his gaÿ-breathèn bozom do rise,

An' his me'th do sheen out ov his eyes:

mirth, shine

An' at last to have praïse or have bleäme,

Is the seäme to Gammony Gaÿ.

When he drove his wold cart out, an' broke

The nut o' the wheel at a butt,

ant-bill

There wer "woo'se things," he cried, wi' a joke,

worse

"To grieve at than crackèn a nut."

An' when he tipp'd over a lwoad

Ov his reed-sheaves woone day on the rwoad,

one

Then he spet in his han's, out o' sleeves,

spat

An' whissel'd, an' flung up his sheaves,

As very vew others can wag,

few, move

Eärm or lag, but Gammony Gaÿ.

arm

He wer wi' us woone night when the band

Wer a-come vor to gi'e us a hop,

An' he pull'd Grammer out by the hand

All down drough the dance vrom the top;

give, dance

Grandma

An' Grammer did hobble an' squall, through

Wi' Gammon a-leädèn the ball;

While Gammon did sheäke up his knee

An' his voot, an' zing "Diddle-ee-dee!"

An' we laugh'd ourzelves all out o' breath

At the me'th o' Gammony Gaÿ. 
ən (h)wen hi: də (h)wisəl ər h^m ıðə:ut ðınkən ə (h)wpt hi:z ədu:ən hi:l biət (h)Iz o:n lagz vər ə drım ən bpb (h)Iz gæi hed tə ðə tjuiən ən ठعn jə mId zi: ətwi:n (h)wə:Ilz (h)Iz fjes a:l ələ:Iv wi (h)Iz smə:Ilz ən (h)Iz gæibri:ðən b $\Lambda z ə m$ də rə:Iz

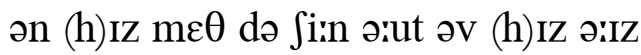
ən at le:st to hav præIz or hav bljem IZ ðə sjem tə gaməni gæI

(h)wen ə dro:v (h)Iz (w)uəld ka:rt ə:ut ən bro:k

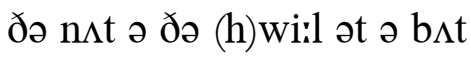
ðər wər wuis ðınz ə krə:Id wi ə dzo:k tə griiv at ðən krakən ə n $\Lambda \mathrm{t}$ ən (h)wen ə tipt orvər ə luəd əv (h)Iz ri:dfiivz (w)u:n de: pn ðə ruəd ðen ə spet In (h)Iz hanz ərut ə sli:vz ən (h)wisəld on flıy $\Lambda p$ (h)Iz Jiivz az veri vju: $\Lambda$ ðəz kən wag ja:rm ər lag bət gaməni gæı

hi: wər wi əs (w)u:n nə:It (h)wen ðə ban(d) wər əkım vər to gi: əs ə hpp ən hi: puld gramər ə:ut b(ə:)I ðə han(d) a:l də:un dru: ðə de:ns vrəm ðə tpp ən gramor did hpbəl ən skwa:l wi gamən əliədən ðə ba:l (h)wə:Il gamən did Jjek $\Lambda p$ (h)Iz ni: ən (h)IZ vut on zin didəlidi:

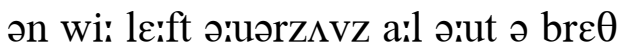
ət ðə mє $\theta$ ə gaməni gæI 
When our tun wer' o' vier he rod

Out to help us, an' meäde us sich fun,

Vor he clomb up to dreve in a wad

O' wet thorns, to the he'th, vrom the tun;

An' there he did stamp wi' his voot,

To push down the thorns an' the zoot,

Till at last down the chimney's black wall

Went the wad, an' poor Gammon an' all:

An' seäfe on the he'th, wi' a grin

On his chin pitch'd Gammony Gaÿ.

All the house-dogs do waggle their tails,

If they do but catch zight ov his feäce;

An' the ho'ses do look over rails,

An' do whicker to zee'n at the pleäce;

An' he'll always bestow a good word

On a cat or a whisselèn bird;

An' even if culvers do coo,

Or an owl is a-cryèn "Hoo, hoo,"

Where he is, there's always a joke

To be spoke, by Gammony Gaÿ. chimney, on fire, rode

\author{
climbed, drive \\ bearth, chimney-top
}


(h)wen əiuər t $\Lambda$ n wər ə və:iər ə rpd ə:ut to help əs ən mjed əs sit $f \wedge n$ var $ə \mathrm{kl} \Lambda \mathrm{m} \Lambda \mathrm{p}$ tə dre:v In $ə \mathrm{wdd}$ ə wet ða:rnz tə ठə he $\theta$ vrəm ठə t $\Lambda$ n ən ठər ə did stamp wi (h)Iz vut tə pus də:un ðə ða:rnz ən ðə zut til ət le:st də:un ðə t $\int$ Imliz blak wa:l went ðə wpd ən pu(:)ər gamən ən a:l

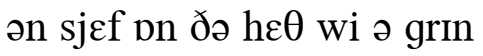

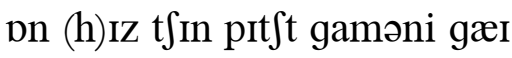

a:l ðə hə:usdpgz də wagəl ðər tærlz If ðe: du: bət kat $\int$ zə:It əv (h)Iz fjes ən ðə hpsız də luk эivər ræilz ən də (h)wikər tə zi:n ət ðə pljes ən hi:l a:lwe:z bisto: a gud wə:rd pn ə kat ar ə (h)wisələn bə:rd ən iivən If k^lvərz də ku: ar ən ə:ul Iz əkrəiən hu: hu: (h)wər hi: Iz ðərz a:lwe:z ə dzo:k tə bi: spo:k b(ə:)I gaməni gæı 
(1) There be the greyhounds! lo'k! an' there's the heäre!

look

(2) What houn's, the squier's, Thomas? where, then, where?

(1) Why, out in Ash Hill, near the barn, behind

Thik tree. (3) The pollard? ${ }^{5}$ (1) Pollard! no, b'ye blind?

that

(2) There, I do zee em over-right thik cow.

(3) The red woone? (1) No, a mile beyand her now.

right opposite

(3) Oh! there's the heäre, a-meäkèn for the drong.

one

(2) My goodness! How the dogs do zweep along,

A-pokèn out their pweinted noses' tips.

pointed

(3) He can't allow hizzelf much time vor slips!

(1) They'll hab'en, after all, I'll bet a crown.

have him

(2) Done vor a crown. They woon't! He's gwäin to groun'.

going

(3) He is! (1) He idden! (3) Ah! 'tis well his tooes isn't, toes Ha' got noo corns, inside o' hobnail shoes.

(1) He's geäme a-runnèn too. Why, he do mwore

Than eärn his life. (3) His life wer his avore.

(1) There, now the dogs wull turn en. (2) No! He's right. bim

(1) He idden! (2) Ees he is! (3) He's out o' zight.

(1) Aye, aye. His mettle wull be well a-tried

Agwaïn down Verny Hill, o' tother zide.

They'll have en there. (3) O no! a vew good hops

going

Wull teäke en on to Knapton Lower Copse.

(2) An' that's a meesh that he've a-took avore.

gap

(3) Ees, that's his hwome. (1) He'll never reach his door.

(2) He wull. (1) He woon't. (3) Now, hark, d'ye heär em now?

(2) O! here's a bwoy a-come athirt the brow

O' Knapton Hill. We'll ax en. (1) Here, my bwoy!

ask bim

Can'st tell us where's the heäre? (4) He's got awoy.

\footnotetext{
${ }^{5}$ Pollard: a tree with its top and upper branches cut back.
} 
ðə hjєər

(dri: o:m ətc:kən o:t)

(1) ðər bi: ðə gre:hə:un(d)z luk ən ðərz ðə hjeər

(2) (h)wpt hə:unz ðə skwə:ıərz tpməs (h)weər ðعn (h)weər

(1) (h)wə:I ə:ut In a $\int$ hil niər ðə ba:rn bihə:In(d) ðık tri: (3) ðə ppla:rd (1) ppla:rd no: bji: blə:ın(d)

(2) ठər ə:I də zi: əm ə:vərə:It ðık kə:u

(3) ðə red (w)u:n (1) no: ə mə:Il bijand (h)ər nə:u

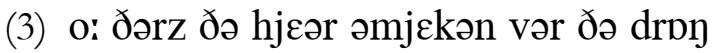

(2) mə:I gudnıs hə:u ðə dpgz də zwi:p əlpy әpo:kən ə:ut ðər pwə:Intıd no:zız tips

(3) ə ke:nt ələ:u hızıf $m \wedge t \int$ tə:Im vər slips

(1) ðe:l habən e:tər a:l ə:Il bet ə krə:un

(2) d $₫$ n vər ə krə:un ðe: wu(:)nt əz gwæin tə grə:un

(3) hi: Iz (1) hi: Idən (3) a: tIz wel (h) Iz tu:z hə gpt nu: ka:rnz insə:Id ə hpbnæil fu:z

(1) hi:z gjem ər^nən tu: (h)wə:I hi: də muər ðən ja:rn (h)Iz lə:If (3) (h)Iz lə:If wər (h)Iz əvuər

(1) ðər nə:u ðə dpgz wul tə:rn ən (2) no: hi:z rə:It

(1) hi: Idən (2) i:s hi: Iz (3) hi:z ərut ə zə:It

(1) æI æI (h)Iz metəl wul bi: wel ətrə:Id әgwæin də:un və:rni hil ə tیðər zə:Id ðe:l hav ən ðعər (3) o: no: a vju: gud hpps wul tjek ən pn tə naptən lo:ər kpps

(2) ən ठats ə me: 万ət hi:v ətuk əvuər

(3) iss ðats (h)Iz huəm (1) hi:l nevər ritt (h)Iz duər

(2) hi: wol (1) hi: wu(:)nt (3) nə:u ha:rk dji: hiər əm nə:u

(2) o: hiərz ə bwə:I əkım əðə:rt ðə brə:u ə naptən hil wi:l a:ks ən (1) hiər mə: bwə:I kənst tel əs (h)wərz ðə hjeər (4) hi:z gpt əwə:I 
(2) Ees, got awoy, in coo'se, I never zeed

A heäre a-scotèn on wi' half his speed.

of course, saw

scooting

(1) Why, there, the dogs be wold, an' half a-done.

old

They can't catch anything wi' lags to run.

(2) Vrom vu'st to last they had but little chance

O' catchèn o'n. (3) They had a perty dance.

first

bim

(1) No, catch en, no! I little thought they would;

He know'd his road too well to Knapton Wood.

(3) No! no! I wish the squier would let me feäre

feed

On rabbits till his hounds do catch thik heäre.

that 
(2) iss gpt əwə:I In ku:s ə:I nevər zi:d ə hjeər əsko:tən pn wi he:f (h)Iz spi:d

(1) (h)wə:I ðعər ðə dpgz bi: (w)uəld ən he:f əd $\Lambda$ n

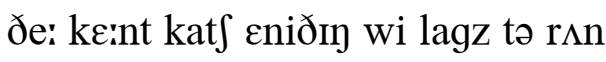

(2) vrəm vıst to le:st ðe: had bət litəl t $\int \varepsilon: n s$

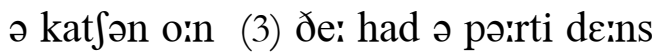

(1) no: kat ən no: ə:I litəl ðっ:t ðe: wud hi: no:d (h)Iz ro:d tu: wel tə naptən wod

(3) no: no: ə:I wI ðə skwə:ır wud let mi: fjeər pn rabits til (h)Iz hə:un(d)z də kat ðık hjeər 
AH! they wer times, when Nanny Gill

Went so'jerèn ageänst her will, soldiering

Back when the King come down to view

His ho'se an' voot, in red an' blue, borse

An' they did march in rows,

An' wheel in lines an' bows, curves

Below the King's own nose;

An' guns did pwoint, an' swords did gleäre,

A-fightèn foes that werden there.

weren't

Poor Nanny Gill did goo to zell

In town her glitt'rèn macarel, mackerel A-pack'd wi' ceäre, in even lots, A-ho'seback in a peäir o' pots.

An' zoo when she did ride so

Between her panniers wide,

Red-cloked in all her pride, Why, who but she, an' who but broke

The road avore her scarlet cloke!

But Nanny's ho'se that she did ride,

Woonce carr'd a sword ageän his zide, An' had, to prick en into rank, once carried A so’jer's spurs ageän his flank;

bim

An' zoo, when he got zight

O' swords a-gleamèn bright, An' men agwaïn to fight, soldier's

He set his eyes athirt the ground, going An' prick'd his ears to catch the sound.

across

Then Nanny gi'ed his zide a kick, An' het en wi' her limber stick; 
nani gil

a: ðe: wər tə:Imz (h)wen nani gil went so:dzərən əgjenst (h)ər wil bak (h)wen ðə kın kım də:un to vju:

(h)Iz hps on vut in red ən blu: ən ðe: did marrt in ro:z ən (h)will in lə:Inz ən bo:z bilo: ðə kinz o:n no:z ən g $\Lambda \mathrm{nz}$ did pwə:Int ən suərdz did gljeər əfə:Itən fo:z ðət wə:rdən ðعər

pu(:)ər nani gil did gu: to zel In təiun (h)ər glitrən makərel əpakt wi kjeər in iivən lpts əhpsbak in ə pjeər ə ppts ən zu: (h)wen $\int i$ i: did rə:Id bitwi:n (h)ər panjərz wə:Id redklo:kt in a:l (h)ər pro:Id (h)wə:I hu: bət $\int i$ i: ən hu: bət bro:k ðə ro:d əvuər (h)ər ska:rlit klo:k

bət naniz hps ðət fii did rə:Id (w)u:ns ka:rd ə suərd əgjen (h)Iz zə:Id ən had to prik ən intə rayk ə so:dzərz spə:rz əgjen (h)Iz flank ən zu: (h)wen hi: gpt zə:It ə suərdz əgli:mən brə:It ən men əgwæin to fə:It hi: set (h)IZ ə:Iz əðə:rt ðə grə:un(d) ən prikt (h)Iz iərz tə kat $\int$ əə sərun(d)

ðعn nani gi:d (h)Iz zə:Id ə kık ən het ən wi (h)ər limbər stık 
But suddenly a horn did sound,

An' zend the ho'semen on vull bound;

An' her ho'se at the zight

Went after em, vull flight,

Wi' Nanny in a fright,

A-pullèn, wi' a scream an' grin,

Her wold brown raïns to hold en in.

old, reins, him

But no! he went away vull bound,

As vast as he could tear the ground,

fast

An' took, in line, a so'jer's pleäce,

Vor Nanny's cloke an' frighten'd feäce;

While vo'k did laugh an' shout

folk

To zee her cloke stream out,

As she did wheel about,

A-cryèn, "Oh! la! dear!” in fright,

The while her ho'se did plaÿ sham fight. 
bət sıdənli ə ha:rn did sə:un(d)

ən z\&n(d) ðə hpsmən pn vul bərun(d)

ən (h)ər hps ət ðə zə:It

went ع:tər əm vul flə:it

wi nani in ə frə:It

əpulən wi ə skrimm ən grın

(h)ər (w)uəld brə:un ræInz to huəld ən In

bət no: hi: went əwə:I vul bə:un(d)

əz vaist əz hi: kud teər ðə grə:un(d)

ən tuk in lə:In ə so:dzərz pljes

vər naniz klo:k ən frə:itənd fjes

(h)wə:il vo:k did le:f ən Jərut

to zi: (h)ər klo:k stri:m ərut

əz fir did (h)wi:l əbərut

əkrə:ıən o: la diər in frə:It

ðə (h)wə:Il (h)ər hos did plæı Jam fə:It 
A-SWAŸÈN slow, the poplar's head,

Above the slopèn thatch did ply,

The while the midnight moon did shed

His light below the spangled sky.

An' there the road did reach avore

The hatch, all vootless down the hill;

wicket-gate

An' hands, a-tired by day, wer still,

Wi' moonlight on the door.

A-boomèn deep, did slowly sound

The bell, a-tellèn middle night;

The while the quiv'rèn ivy, round

The tree, did sheäke in softest light.

But vootless wer the stwone avore

The house where I, the maiden's guest,

At evenèn, woonce did zit at rest

once

By moonlight on the door.

Though till the dawn, where night's a-meäde

The day, the laughèn crowds be gaÿ,

Let evenèn zink wi' quiet sheäde,

Where I do hold my little swä̈ .

An' childern dear to my heart's core,

A-sleep wi' little heavèn breast,

That pank'd by day in plaÿ, do rest

panted

Wi' moonlight on the door.

But still 'tis good, woonce now an' then,

To rove where moonlight on the land

Do show in vaïn, vor heedless men,

The road, the vield, the work in hand, 
mu:nlə:It pn ðə duər

əswæiən slo: ðə ppplərz hed əb $\Lambda \mathrm{V}$ ðə slo:pən ðat $\int \mathrm{did}$ plə:I

ðə (h)wə:Il ðə midnə:It mu:n did $\int \varepsilon d$

(h)Iz lə:It bilo: ðə spangəld skə:I

ən ðər ðə ro:d did riit

ðə hat $\int$ a:l vutlıs də:un ðə hıl

ən han(d)z ətə:Iərd b(ə:)I de: wər stıl

wi mu:nlə:it pn ðə duər

əbu:mən di:p did slo:li sə:un(d)

ðə bel ətદlən mıdəl nə:It

ðə (h)wə:Il ðə kwIvrən ə:Ivi rə:un(d)

ðə tri: did Jjek in spftist lə:it

bət vutlis wər ðə stuən əvuər

ðə hə'us (h)wər ə:I ðə mæIdənz gest

ət iivmən (w)uins did zit at rest

b(ə:)I mu:nlə:it pn ðə duər

ðо: tıl ðə de:n (h)wər nə:Its əmjed

ðə de: ðə le:fən krə:udz bi: gæı

let i:vmən zink wi kwə:ıət $\int j \varepsilon d$

(h)wər ə:I də huəld mə:I litəl swæI

ən tfIldərn diər tə mə:I ha:rts kuər

əsli:p wi litəl hiivən brest

ðət paykt b(ə:)I de: In plæI də rest

wi mu:nlə:It pn ðə duər

b $\Lambda$ t strl tız gud (w)u:ns nə:u ən ðعn

tə ro:v (h)wər mu:nlə:It pn ðə lan(d)

də fo: In væIn vər hi:dlis men

ðə ro:d ðə vi:l(d) ðə wə:rk in han(d) 
When curtains be a-hung avore

The glitt'rèn windows, snowy white,

An' vine-leaf sheädes do sheäke in light

shadows

O' moonlight on the door. 
(h)wen kərrtənz bi: əh^y əvuər ðә glitrən windərz sno:i (h)wə:It ən və:Inli:f $\int j \varepsilon d z$ də $\int j \varepsilon k$ In lə:It ә mu:nlə:It pn ðə duər 
MY LOVE'S GUARDIAN ANGEL

As in the cool-air'd road I come by,

-in the night,

Under the moon-clim'd height o' the sky,

-climbed

-in the night,

There by the lime's broad lim's as I staÿ'd,

Dark in the moonlight, bough's sheädows plaÿ'd

Up on the window-glass that did keep

Lew vrom the wind, my true love asleep,

sheltered

-in the night.

While in the grey-wall'd height o' the tow'r, -in the night,

Sounded the midnight bell wi' the hour,

-in the night,

There lo! a bright-heäir'd angel that shed

Light vrom her white robe's zilvery thread,

Put her vore-vinger up vor to meäke

Silence around lest sleepers mid weäke,

—in the night.

“Oh! then,” I whisper'd, "do I behold

-in the night.

Linda, my true-love, here in the cwold,

—in the night?"

"No," she meäde answer, "you do misteäke:

She is asleep, but I that do weäke,

Here be on watch, an' angel a-blest,

Over her slumber while she do rest,

—in the night."

"Zee how the winds, while here by the bough,

-in the night, 
mə:I $1 \Lambda v z$ ga:rdiən andzəl

az In ðə ku:lærd ro:d ə:I kım bə:I

In ðə nə:It

^ndər ðə mu:nklimd hə:It ə ðə skə:I

In ðə nə:It

ðər b(ə:)I ðə lə:Imz bro:d limz əz ə:I stæId

da:rk in ðə mu:nlə:It bə:uz Sadərz plæId

$\Lambda$ p pn ðə windərglais ðət did ki:p

lu: vrəm ðə win(d) mə:i tru: $1 \Lambda \mathrm{v}$ əsli:p

In ठə nə:It

(h)wə:Il in ðə gre:wa:ld hə:It ə ðə tə:uər

In ठə nə:It

sə:un(d)Id ðə midnə:It bel wi ði ə:uər

In ठə nə:It

ðər lo: ə brə:Ithjeard andzəl ठət $\int \varepsilon d$

lə:It vrəm (h)ər (h)wəit ro:bz zilvəri dred

$\mathrm{p} \Lambda \mathrm{t}(\mathrm{h}) \partial r$ vuərvingər $\Lambda \mathrm{p}$ vər to mjek

sə:Iləns ərə:un(d) lest sli:pərz mid wjek

In ðə nə:It

o: ðعn ə:I (h)wispərd du: ə:I bihuəld

In ðə nə:It

lində mə:I tru: $1 \Lambda \mathrm{v}$ hiər In ðə kuəld

In ðə nə:It

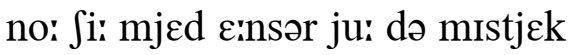

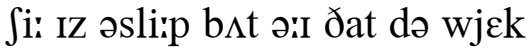

hiər bi: pn wpt $\int$ ən andzəl əblest

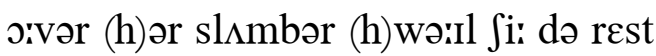

In ðə nə:It

zi: hə:u ðə win(d)z (h)wə:Il hiər b(ə:)I ðə bə:u

In ठə nə:It 
They do pass on, don't smite on her brow,

—in the night;

Zee how the cloud-sheädes naïseless do zweep

shadows, noiselessly

Over the house-top where she's asleep.

You, too, goo by, in times that be near,

You too, as I, mid speak in her ear

may

-in the night." 
ðе: də pa:s pn do:nt smə:It pn (h)ər brə:u

In ðə nə:It

zi: hə:u ðə klə:udfjedz næızlıs də zwi:p

o:vər ðə hə:ustop (h)wər Ji:z əsli:p

ju: tu: gu: bə:I In tə:Imz ðət bi: niər

ju: tu: az ə:I mId spi:k in (h)ər iər

In ðə nə:It 
Ov all the meäds wi' shoals an' pools,

Where streams did sheäke the limber zedge,

pliant

An' milkèn vo'k did teäke their stools,

folk

In evenèn zun-light under hedge:

Ov all the wears the brook did vill,

weirs

Or all the hatches where a sheet

O’ foam did leäp below woone's veet,

one's

The pleäce vor me wer Leeburn Mill.

An' while below the mossy wheel

All day the foamèn stream did roar,

An' up in mill the floatèn meal

Did pitch upon the sheäkèn vloor,

We then could vind but vew han's still,

Or veet a-restèn off the ground,

An' seldom hear the merry sound

O’ geämes a-plaÿ'd at Leeburn Mill.

But when they let the stream goo free,

Bezide the drippèn wheel at rest,

An' leaves upon the poplar-tree

Wer dark avore the glowèn west;

An' when the clock, a-ringèn sh'ill,

loudly

Did slowly beät zome evenèn hour,

Oh! then 'ithin the leafy bow'r

Our tongues did run at Leeburn Mill.

An' when November's win' did blow,

Wi' hufflèn storms along the plaïn,

gusty

An' blacken'd leaves did lie below

The neäked tree, a-zoak'd wi' raïn, 
li:bə:rn mil

əv a:l ðə miədz wi fo:lz ən pu:lz

(h)wər stri:mz did Jjek ðə limbər zedz

ən milkən vo:k did tjek ðər stu:lz

In i:vmən zınlə:It $\Lambda$ ndər hedz

əv a:l ðə weərz ðə bruk did vil

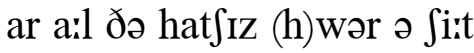

ə fo:m did liəp bilo: (w)u:nz viit

ðə pljes vər mi: wər li:bə:rn mil

ən (h)wə:ıl bılo: ðə mpsi (h)wi:l

a:l de: ðə fo:mən stri:m did ruər

ən $\Lambda$ p in mil ðə flo:tən mi:l

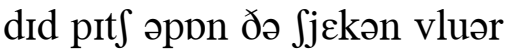

wi: ðen kud və:In(d) bət vju: hanz stıl

ar vi:t ərestən pf ðə grə氵un(d)

ən seldəm hiər ðə meri sə:un(d)

ə gjemz əplæid ət li:bə:rn mıl

bət (h)wen ðe: let ðə stri:m gu: fri:

bızə:Id ðə dripən (h)will ət rest

ən liivz əppn ðə ppplərtri:

wər da:rk əvuər ðə glo:ən west

ən (h)wen ðə klpk ərıjən $\int \mathrm{I} l$

did slo:li biət z^m i:vmən ə:uər

o: ðعn Iðın ðə li:fi bə:uər

ə:uər tıyz did rın ət li:bərrn mil

ən (h)wen no:vembərz win did blo:

wi h^flən sta:rmz əlpy ðə plæın

ən blakənd liivz did lə:ı bilo:

ðə njekıd tri: əzo:kt wi ræın 
I werden at a loss to vill

wasn't

The darkest hour o' raïny skies,

If I did vind avore my eyes

The feäces down at Leeburn Mill. 
ว:I wərrdən at ə los to vil

ðə da:rkist ə:uər ə ræIni skə:IZ

If ə:I did və:In(d) əvuər mə:I ə:IZ

ðə fjesız də:un ət li:bə:rn mil 
We Do'set, though we mid be hwomely, may

Be'nt asheäm'd to own our pleäce;

An' we've zome women not uncomely;

Nor asheäm'd to show their feäce:

We've a meäd or two wo'th mowèn, worth

We've an ox or two wo'th showèn,

In the village,

At the tillage,

Come along an' you shall vind

That Do'set men don't sheäme their kind.

Friend an' wife,

Fathers, mothers, sisters, brothers,

Happy, happy, be their life!

Vor Do'set dear,

Then gi'e woone cheer;

give one

D'ye hear? woone cheer!

If you in Do'set be a-roamèn,

An' ha' business at a farm,

Then woont ye zee your eäle a-foamèn!

ale

Or your cider down to warm?

Woont ye have brown bread a-put ye,

An' some vinny cheese a-cut ye?

Butter? —rolls o't!

blue vinny (made from skimmed milk)

Cream?-why bowls o't!

of it

Woont ye have, in short, your vill,

A-gi'ed wi' a right good will?

given

Friend an' wife,

Fathers, mothers, sisters, brothers,

Happy, happy, be their life!

Vor Do'set dear,

Then gi'e woone cheer;

give one

D'ye hear? woone cheer! 
præIz ə dpsət

wi: dpsət ðo: wi: mId bi: huəmli

be:nt $ə \int j \varepsilon m d$ tu o:n əruər pljes

ən wi:v zəm wumin not $\Lambda$ nk $\Lambda$ mli

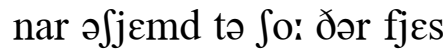

wi:v ə miəd ər tu: wpð mo:ən

wi:v ən pks ər tu: woð fo:ən

In ðə viləd 3

at ðə tıləd3

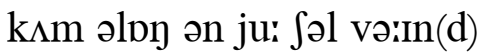

ðət dpsət men do:nt $\int j \varepsilon m$ ðər kə:In(d)

fren(d) ən wə:If

fє:ðərz m^ðərz sistərz br^ðərz

hapi hapi bi: ðər lə:If

vər dpsət diər

ðદn gi: (w)u:n t fior

dji: hiər (w)uin tfiər

If ju: in dpsət bi: əro:mən

an ha biznis ot ə fairm

ðعn wu(:)nt i: zi: jər jel əfo:mən

ar jər səisdər də:un tə warm

wu(:)nt i: hav brə:un bred əp $\Lambda$ t i:

ən səm vini tfizz əkıt i:

b $\Lambda$ tər ro:lz o:t

kre:m (h)wa: bo:lz o:t

wu(:)nt i: hav in Jairt jər vil

agiəod wi ə rə:It gud wil

fren(d) on wə:If

fє:ðərz m^ðərz sistərz brıðərz

hapi hapi bi: ðər lə:If

vər dosət diər

ðen gi: (w)u:n t tiər

dji: hiər (w)u:n t fiər 
An' woont ye have vor ev'ry shillèn,

Shillèn's wo'th at any shop,

Though Do'set chaps be up to zellèn,

An' can meäke a tidy swop?

Use em well, they'll use you better;

In good turns they woont be debtor.

An' so comely,

An'so hwomely,

Be the maidens, if your son

Took woone o'm, then you'd cry "Well done!"

one of them

Friend an' wife,

Fathers, mothers, sisters, brothers,

Happy, happy, be their life!

Vor Do'set dear,

Then gi'e woone cheer;

D'ye hear? woone cheer!

If you do zee our good men travel,

Down a-voot, or on their meäres,

borses

Along the windèn leänes o' gravel,

lanes

To the markets or the feäirs,-

Though their ho'ses cwoats be ragged,

horses'

Though the men be muddy-laggèd,

Be they roughish,

Be they gruffish,

They be sound, an' they will stand

By what is right wi' heart an' hand.

Friend an' wife,

Fathers, mothers, sisters, brothers,

Happy, happy, be their life!

Vor Do'set dear,

Then gi'e woone cheer;

give

D'ye hear? woone cheer! 


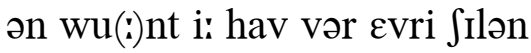

SIlənz wpð ət $\varepsilon n i \int p p$

ðo: dpsət tfaps bi: $\Lambda p$ tə zelən

ən kən mjek ə tə:Idi swpp

ju:z əm wel ðe:l ju:z ju: betər

In gud tə:rnz ðe: wu(:)nt bi: detər

ən sə k^mli

ən sə huəmli

bi: ðə mæIdənz If jər $s \Lambda n$

tuk (w)u:n o:m ðعn jəd krə:I wel d $\Lambda$ n

fren(d) ən wə:If

fє:ðərz m^ðərz sistərz brıðərz

hapi hapi bi: ðər lə:If

vər dpsət diər

ðદn gi: (w)u:n t fiər

dji: hiər (w)u:n tfiər

If ju: də zi: əruər gud men travəl

dərun əvut ar pn ðər mjeərz

əlpy ðə wə:In(d)ən ljenz ə gravəl

tə ðə ma:rkits ər ðə fjeərz

ðо: ðər hpsız kuəts bi: ragid

ðо: ðə men bi: m^dilagid

bi: ðe: $\mathrm{r} \Lambda \mathrm{fi} \int$

bi: ðe: gr $\Lambda \mathrm{fI} \int$

ðe: bi: $\operatorname{sorun}(d)$ ən ðe: wil stan(d)

b(ə:)I (h)wpt IZ rə:It wi ha:rt ən han(d)

fren(d) ən wərIf

fє:ðərz m^ðərz sistərz br^ðərz

hapi hapi bi: ðər lə:If

vər dpsət diər

ðعn gi: (w)u:n t tior

dji: hiər (w)u:n tfiər 



\section{TEXTUAL NOTES}

Emendations in wording are normally made only where there is support (not recorded here) from at least one version other than 1879; emendations in punctuation are made, with or without support from other versions, where the punctuation of 1879 would be likely to impede understanding. References to the poems are given by page and line number, the complete line being quoted for ease of reference.

\section{A FATHER OUT, AN' MOTHER HWOME}

54/28 Wer ashen poles, a-castèn straïght, ashen] ashèn 1879

\section{RIDDLES}

60/12 I went, an' didden touch a drop o't.

$$
\text { o't.] , } 1879
$$

60/18 A. Aye I do hear your chucklèn droat.

droat.] No punctuation 1879

60/20 Zome water on my head vrom spring, spring,] . 1879

60/21 Then under water an' o' top o't

o't] , 1879

62/16 A. Horn vor the mouth's a hornen cup. hornen] hornèn 1879

\section{DAY'S WORK A-DONE}

66/13 Above the trees that kept us lew, lew,] ; 1879

66/21 A-rottlèn loud, an' foamèn white, white,] . 1879 


\section{THE MOTHERLESS CHILD}

88/13 Thy looks be always dear to me.

No break between stanzas 1879

\section{THE LEÄDY'S TOWER}

94/2 Our comèn, we can goo inside. we] wi’ 1879

94/3 The door is oben now." An' zoo now."] No closing quotation marks 1879

94/12 Wer zeven zights o' wedded life. life.] " 1879

\section{MEÄRY'S SMILE}

114/29 To turn the hardest work to plaÿ: plaÿ:] . 1879

THE YOUNG THAT DIED IN BEAUTY

124/13 The slowly-weästen years ha' rolled rolled] , 1879

\section{THE SCUD}

132/20 Unless the air did blow blow] , 1879

132/21 Drough ruslèn leaves, an' drow drow] $\sim, 1879$

134/3 An' zome ha' smiles vor strangers' view, view,] ; 1879

THE LOVELY MAÏD OV ELWELL MEÄD

142/8 O leänèn lawns ov Allen,

$$
\text { Allen,] . } 1879
$$


142/9 Would be mwore teäkèn where there straÿ'd there] they 1879

\section{CULVER DELL AND THE SQUIRE}

152/19 Wi' red-eär'd dogs bezide his knees, knees,] . 1879

THE VIER-ZIDE

180/24 An' where I heärd his vaïce's sound, vaïce's] vaïces 1879

182/15 Do gather souls that time do speäre Do] Go 1879

\section{MILKÈN TIME}

206/4 To build upon the mossy lim' lim'] , 1879

206/13 Along the path a vew steps on, on,] . 1879

\section{WHEN BIRDS BE STILL}

208/26 Zoo teäke, vor me, the town a-drown'd a-drown'd] , 1879

\section{ZUN-ZET}

216/8 Sorrow-slightèn, work-vorgettèn, -vorgettèn,] . 1879

216/9 Gambol'd wi' the zun a-zettèn. -zettèn] -zetten 1879

\section{SPRING}

220/11 High above the ashes' sh'oud. ashes'] ashes 1879 
THE WATER CROWVOOT

226/2 O small-feäc'd flow'r that now dost bloom

O] O' 1879

THE BLACKBIRD [II]

234/5 On western clouds a vi'ry red, red,] ; 1879

\section{THISSLEDOWN}

242/2 The thissledown by winds a-roll'd winds] wind's 1879

\section{THE LEÄNE}

258/29 Ov our goslèns do creep vrom the agg, agg,] . 1879

260/30 But his vield an' the grass wer a-let, wer a-let] wer-a-let 1879

\section{TREES BE COMPANY}

274/5 The workvo'k in their snow-white sleeves, sleeves,] . 1879

\section{BROOKWELL}

288/13 The stwonen arch's lofty bow.

stownen arch's] stwonèn archès 1879

THE WINTER'S WILLOW

300/11 Or zit a-milkèn where do droop droop] , 1879

\section{FIFEHEAD}

320/16 an' laugh'd in light o' maïdens' eyes, maïdens'] maïden's 1879 


\section{THE WIFE A-LOST}

$342 / 28$ I'll praÿ wi' woone sad vaïce vor greäce sad] said 1879

\section{VO'K A-COMÈN INTO CHURCH}

354/28 Their vaice is there vor God alwone; alwone;] no punctuation 1879

\section{THE BWOAT}

372/10 Till, out by sheädy rocks there show'd show'd] , 1879

\section{THE PLEÄCE OUR OWN AGEÄN}

376/29 A road's a-meäde by Grenley Bridge.

A road's] A-road's 1879

ECLOGUE: John an' Thomas

384/19 To much on groun' a mile vrom hwome.

hwome.] no punctuation 1879

\section{THE MEÄD IN JUNE}

396/8 Or trickle thin in zummer-tide, zummer-tide,] ; 1879

\section{GRUFFMOODY GRIM}

416/26 An' I'll laugh till my two zides do eäche; eäche;] no punctuation 1879

\section{THE SPARROW CLUB}

424/21 Below their merry chin, min,

$$
\text { min,] . } 1879
$$

\section{MOONLIGHT ON THE DOOR}

$442 / 29$ The road, the vield, the work in hand, hand,] . 1879 
MY LOVE'S GUARDIAN ANGEL

448/6 You too, as I, mid speak in her ear as] ’ 1879

446/20-21 “Oh! then," I whisper'd, "do I behold | —in the night, night,] . 1879

\section{LEEBURN MILL}

450/13 Did pitch upon the sheäkèn vloor, vloor,] . 1879 




\section{APPENDIX: A SUMMARY OF SECTIONS 7 AND 8 OF WBPG}

This summary gives only the conclusions reached, usually omitting the arguments leading to those conclusions and the comparisons with neighbouring districts. Addenda to the original guide are enclosed in curly brackets. Vowels are arranged according to Wells's classification in his Accents of English (1.xviii-xix), reproduced below.

\begin{tabular}{|c|c|c|c|c|}
\hline RP & $\begin{array}{l}\text { Gen } \\
\text { Am }\end{array}$ & No & KEYWORD & Examples \\
\hline I & I & 1. & KIT & ship, sick, bridge, milk, myth, busy ... \\
\hline e & $\varepsilon$ & 2. & DRESS & step, neck, edge, shelf, friend, ready ... \\
\hline æ & $æ$ & 3. & TRAP & tap, back, badge, scalp, hand, cancel ... \\
\hline $\mathrm{p}$ & a & 4. & LOT & stop, sock, dodge, romp, quality ... \\
\hline$\Lambda$ & $\Lambda$ & 5. & STRUT & cup, suck, budge, pulse, trunk, blood ... \\
\hline u & $u$ & 6. & FOOT & put, bush, full, good, look, wolf ... \\
\hline a: & $æ$ & 7. & BATH & staff, brass, ask, dance, sample, calf ... \\
\hline $\mathrm{p}$ & 0 & 8. & CLOTH & cough, broth, cross, long, Boston ... \\
\hline ว: & ər & 9. & NURSE $^{6}$ & hurt, lurk, burst, jerk, term ... \\
\hline i: & $\mathrm{i}$ & 10. & FLEECE & creep, speak, leave, feel, key, people ... \\
\hline eI & eI & 11. & FACE & tape, cake, raid, veil, steak, day ... \\
\hline a: & a & 12. & PALM & psalm, father, bra, spa, lager ... \\
\hline o: & 0 & 13. & THOUGHT & taught, sauce, hawk, jaw, broad ... \\
\hline$\partial U$ & o & 14. & GOAT & soap, joke, home, know, so, roll ... \\
\hline u: & $\mathrm{u}$ & 15. & GOOSE & loop, shoot, tomb, mute, huge, view ... \\
\hline aI & aI & 16. & PRICE & ripe, write, arrive, high, try, buy ... \\
\hline गI & गI & 17. & CHOICE & adroit, noise, join, toy, royal ... \\
\hline $\mathrm{au}$ & au & 18. & MOUTH & out, house, loud, count, crowd, cow ... \\
\hline Іә & $\mathrm{I}(\mathrm{r}$ & 19. & NEAR & beer, sincere, fear, beard, serum ... \\
\hline عə & $\varepsilon(\mathrm{r}$ & 20. & SQUARE & care, fair, pear, where, scarce, vary ... \\
\hline a: & $\mathrm{a}(\mathrm{r}$ & 21. & START & far, sharp, bark, carve, farm, heart ... \\
\hline o: & $\mathrm{o}(\mathrm{r}$ & 22. & NORTH & for, war, short, scorch, born, warm ... \\
\hline o: & $\mathrm{o}(\mathrm{r}$ & 23. & FORCE & four, wore, sport, porch, story ... \\
\hline Uə & $U(\mathrm{r}$ & 24. & CURE & poor, tourist, pure, plural, jury ... \\
\hline
\end{tabular}

${ }^{6}$ Wells's symbols for this set are in fact /3:/ and /3r/. In order to use as few symbols as possible I have substituted /ə/ for /3/, as originally used by Daniel Jones and as re-adopted by $A E D$ and by $O E D$ in its latest online revision. 


\section{VOWELS}

\subsection{The KIT set}

The KIT set (Wells, 2.2.1) contains words with a stressed syllable that has the sound /I/ (generally called "short $i$ ") in both RP and GenAm.

7.1.1 In $\$ 16$ of the Diss. Barnes draws a distinction between the vowel sounds in wit and dip in proto-RP, the former being higher than the latter. This may help to explain why words with short $i$ (presumably of the dip type) are sometimes spelled with $e$ and rhymed with words with a stressed syllable that has the sound $/ \varepsilon /$.

7.1.2 Final $-y$ or -ey ("the bappY vowel", as Wells engagingly calls it) is always /i/ rather than /I/.

7.1.3 I have not found any way of predicting which of the two subsets words with short $i$ will belong with, WIT or DIP, and Barnes appears not to distinguish between them in rhyme. Accordingly, though I transcribe final $y$ and $e y$ as $/ \mathrm{i} /$ in accordance with 7.1.2, I use /I/ for all instances of short $i$ that are spelled with $i$, except where other factors (such as the loss of $-\nu$ - in give or -th in with) suggest heightening and/or lengthening of the vowel.

7.1.4 Where spelling and/or rhyme point to an entirely different phoneme in place of short $i$, I transcribe accordingly. For example:

a) bridge and ridge always have the vowel $/ \Lambda /$;

b) pick, rick, hit, spit, if, and a few other words are sometimes spelled with $e$ for $i$, in which case I transcribe the vowel as $/ \varepsilon /$;

c) for grist (rhyming with hoist) see 7.16.11.

7.1.5 In both the broad and the modified forms of the dialect Barnes uses the spelling -in for the unstressed -ing ending on present participles and verbal nouns. There is no apparent difference in pronunciation between this and the unstressed -en ending of amalgamated negatives (e.g. didden), past participles of strong verbs (e.g. given), or other words ending in -en (e.g. maiden, often). Rhymes suggest that the normal pronunciation is /on/, with /In/ and possibly / $\mathrm{en/} \mathrm{as} \mathrm{an} \mathrm{occasional} \mathrm{variant.}$ 
7.1.6 I take the word min to mean 'man' or 'mate' or 'friend' and the pronunciation to be $/ \mathrm{mm} /$.

7.1.7 Loss of final /ð/ in with (shown by the frequent spelling wi') leads to raising of / $/$ / to /i/ and possibly lengthening to /ii/ (see 8.13.2).

7.1.8 Loss of /v/ in give (shown by the spelling gi'e) leads to raising and lengthening of / I/ to /i:/ (see 8.15.1).

7.1.9 I take the pronunciation of the stressed syllable in the word spirit to be /sparr/ irrespective of the spelling (spurrit, spirit, or speret), and of that in squirrel (spelled thus or squerrel) to be /skwar/\}.

7.1.10 The pronunciation of women may be /wəmin/ or /wumin/.

\subsection{The DRESS set}

The DRESS set (Wells, 2.2.2) contains words with a stressed syllable that has the vowel generally called "short $e$," /e/ in RP and / $\varepsilon /$ in GenAm. Words with this vowel may have one of three pronunciations in Barnes's poems: $/ \varepsilon /, / \mathrm{I} /$, or $/ \mathrm{a} /$.

7.2.1 The usual pronunciation is $/ \varepsilon /$, as in StE.

7.2.2 /I/ for $/ \varepsilon /$. Some words sometimes have /I/ for $/ \varepsilon /$, but the evidence suggests that $/ \mathrm{I} /$ is only an occasional variant. I therefore transcribe the vowel as $/ \varepsilon /$ except where spelling or rhyme show that Barnes intended the pronunciation with $/ \mathrm{I} /$.

7.2.3 /a/ (see 7.3, TRAP) for $/ \varepsilon /$. Barnes comments that in Dorset " $a$ is frequently substituted for $e$ : as in bag, beg[;] bagger, begger; kag, keg; agg, egg; lag, leg" (Diss., \$18). The substitution is also found in words that do not have the combination -eg: drash (thresh), drashel (threshold), langth (length), alassen (unless), strangth (strength), stratch (stretch), watshod (wetshod), and yaller (yellow: 3 instances only, all in 1844, the more usual spelling being 
yoller, see further 7.4 below). I transcribe the vowel as $/ \varepsilon /$ except where spelling or rhyme show that Barnes intended the pronunciation with $/ \mathrm{a} /$.

\subsection{The TRAP set}

The TRAP set (Wells, 2.2.3) contains words with a stressed syllable that has the vowel generally called "short a." It contains all words with /æ/ in RP and those words with $/ \mathfrak{x} /$ in GenAm that do not belong in the BATH set (7.7 below).

7.3.1 "In most rural western speech the TRAP vowel is qualitatively [a] rather than [æ]"(Wells, 4.3.7, p. 345). I have assumed that this is true for Barnes's poems.

7.3.2 There is a small group of words spelled with $a$ in StE showing variation in spelling between $a$ and $o$ in Barnes's poems (gnat, sat, and a few words spelled with $o$ in StE discussed under 7.4), presumably reflecting variation in pronunciation between $/ \mathrm{a} /$ and $/ \mathrm{p} /$. I have assumed an intermediate pronunciation between the two, i.e. /a/.

\{Rottle (always so spelled) may appear to be a form of rattle, like zot for sat. OED notes, however, that rattle and rottle have different origins, the first "related to Dutch ratelen to chatter, babble, to make a rattling or clacking sound," the second "to Middle Dutch rotelen to rattle, to clatter, to breathe laboriously, to wheeze." We may take it, accordingly, that the vowel in rottle is $/ \mathfrak{p} /$, not $/ \mathrm{a} /$. Similarly with yoppèn ('yapping'): EDD records spellings with $o$ and pronunciations with $/ \mathrm{p} /$ in several SW counties, including Dorset.

7.3.3 Spelling and rhyme evidence show that in Barnes's poems the verb carry becomes / karr/, with loss of final / i/ and lengthening of the vowel to /a:/.

7.3.4 On the evidence of the short $a$ in OED (s.v. clavel) I have assumed that clavy has a short $a$ in Barnes's poems, i.e. /a/.

7.3.5 I have assumed that the vowel in unstressed and, as, at, than, that, etc. is reduced to /o/, as in $\mathrm{RP}$. 
7.3.6 For plait, a member of the TRAP set in RP, see 7.11.6 below.

\subsection{The LOT set}

The LOT set (Wells, 2.2.4) contains words with a stressed syllable that has the vowel generally called "short 0. " This includes words with / $\mathrm{p} /$ in RP (excluding those that belong in the CLOTH set, 7.8 below) and /a/ in GenAm, whether spelled with o (top, pot, dog, clock, copse, etc.) or with a (what, watch, want, wasp, etc.).

In Barnes's poems the vowel is normally $/ \mathrm{p} /$, in spite of the general unrounding in the SW to $/ \mathrm{a} /$. There is a handful of words that show variation in spelling between $a$ and $o$ : drop, John and Johnny, yond (in beyond and yonder), and yellow (yaller or yoller in 1844, always yollow in the modified form of the dialect). As with gnat and sat in 7.3.2 I assume that the vowel is /a/, intermediate between $/ \mathrm{a} /$ and $/ \mathrm{p} /$.

7.4.1 I assume that the vowel in unstressed from and in of when spelled $o$ ' (for which see 8.3.2) is reduced to /o/, as in RP.

\{7.4.2 The hovel / shovel rhyme in "Eclogue: The 'lotments" may strike RP speakers as a half-rhyme, but, since $O E D$ gives $/ \mathrm{h} \Lambda \mathrm{v} /$ as an alternative to / hpv/ for the stressed syllable, we may take it as a full rhyme on the sound $/ \Lambda \mathrm{val} /$.

\subsection{The STRUT set}

The STRUT set (Wells, 2.2.5) contains words with a stressed syllable that has the vowel $/ \Lambda /$, generally called "short $u$," in both RP and GenAm.

7.5.1 There was no distinction in ME between the vowel sound in cut and that in put: both had the sound / $/$, as they still do in the north of England. In Barnes's poems, as in RP and the south of England generally, the sound is normally $/ \Lambda /$. 
7.5.2 A few words in Barnes's poems have $/ \Lambda /$ where they do not have it in RP: put, pudding, roof (usually spelled ruf), bosom (frequently burzom in 1844), self (frequently spelled zuf, especially in myzuf, etc.). (I have assumed that the stressed syllables in butcher and hovel (for which see 7.4.2) likewsise have $/ \Lambda /\}$. Occasional rhymes between words with $/ \Lambda /$ and words from Wells's GOAT set suggest that the second element of that diphthong would have been $/ \Lambda /$ or $/ \partial /$ (see further 7.14.3).

7.5.3 Love and the stressed syllable of above have / $\Lambda /$, as in RP; but it is not clear whether rhymes between one of these and other words ending in -ove (move, prove, grove, drove, rove) are true rhymes or simply eye-rhymes. Jennings's rhymes and spellings—appruv, appruv'd (rh. lov'd), pruv (outside rhyme as well as rh. love), pruf (proof), ruf (roof), rum (room), shut (shoot, rh. put)-suggest that in the early 19th century some words with /u:/ in RP (prove approve, proof, roof, room, shoot) had $/ \Lambda /$ in East Somerset, thus supporting Barnes's rhyming not only of move / prove / love / above but also of roof / buff / stuff / enough. It seems reasonable therefore to transcribe move, prove, and roof with $/ \Lambda /$ in Barnes's poems \{although the two occurrences in 1844 of the spelling môv(in "The milk-mâid o' the farm" and "Looks a-know'd avore") may suggest /mo:v/ as an alternative for move $\}$; but drove, grove and rove remain problematic.

7.5.4 The words rut, strut, and a-strut are always spelled with -out in Barnes's poems and are rhymed only with the word out. It is clear that their vowel is the / oru/ diphthong of the MOUTH set (see 7.18.1, 7.18.4).

7.5.5 That crust and dust sometimes have $/ \Lambda /$ as in RP is shown by rhyme, but Barnes's preferred spelling for both words outside rhyme is with -oust, suggesting that his preferred pronunciation for these words, too, is with the diphthong / əu/ (see again 7.18.1, 7.18.4).

7.5.6 In its sole occurrence in rhyme (with dust) just is spelled (and evidently pronounced) as in StE, /d $3 \wedge$ st/. But Barnes's normal spellings in 1844 are jis' and jist, suggesting that his preferred pronunciations are /dzis/ and /dzIst/. \{Similarly such is always spelled sich in 1844 (apart from two occurrences of such in "Ānt's tantrums"); and in "Bees a-zwarmen" it is 
rhymed with ditch and pitch, showing that the preferred pronunciation was /sits/. In later editions, however, such is also frequently used, suggesting that /s st S/ was an acceptable alternative.\}

7.5.7 Spelling and rhyme suggest three possible pronunciations for one (and for the pre-final element of once) in Barnes's poems: /u:n/, /wu:n/, and (as in RP) /wan/. The word arn, which occurs only in "The witch" in 1844 and 1847 , is not another form of one, but a contraction of the phrase ever a one.

7.5.8 Although none is descended from the same OE root as one, its spelling (nuone in 1844, nwone in the modified form of the dialect) and its use in rhyme suggest different development in the dialect, the likely pronunciation being /nu n/ or /nuən/. As with arn (see 7.5.7) so with narn: it is a contraction of never a one (not entered in the 1844 Glossary), pronounced /na:rn/.

7.5.9 For among (RP/om^y/) see 7.8.3.

7.5.10 I have assumed that words such as but, must, up, us, etc. have unstressed forms with $/ \mathrm{\partial} /$ for $/ \Lambda /$, as in RP.

\subsection{The FOOT set}

The FOOT set (Wells, 2.2.6) contains words with a stressed syllable that has the vowel / $/$ in both RP and GenAm. Most words belonging to this set can be expected to have / $\mathrm{U} /$ in Barnes's poems, just as in RP. The following additional points should be noted:

7.6.1 Some words that have / / in RP have / $\Lambda$ in Barnes's poems, e.g. put and bosom (see 7.5.2); there is, however, no evidence to suggest that push and bush do not have / $/$ as in RP.

7.6.2 Some words with /u:/ in RP have / $/$ in Barnes's poems, e.g. food, mood, and moot ('tree-stump'). \{The rhyme mood / a-woo'd in the refrain of "Meäry wedded" suggests, however, that RP /mu:d/ is an acceptable alternative for mood.\} 
7.6.3 Some words with /u:/ in RP may have either / $/$ / or /u:/ in Barnes's poems, e.g. shoot, rhyming with foot and soot as well as with flute.

7.6.4 Some words with / $/$ in RP may have either / $/$ or /u: in Barnes's poems, e.g. wool, which rhymes not only with pull but also with pool.

7.6.5 Look is frequently spelled $10^{\prime} k$ in 1844 , but it is rhymed only with brook, nook, and other words having the vowel / $/$, as in RP. In the absence of any firm evidence to the contrary, I transcribe all forms of look as / luk/, irrespective of their spelling. Lauk has no connection with look: it is an exclamation corrupted from Lord (of the same type as gosh from God), and has, I assume, its normal pronunciation, / lo:k/.

\subsection{The BATH set}

The BATH set (Wells, 2.2.7) contains words with a stressed syllable that has the vowel /a:/ in RP and /æ/ in GenAm: staff, brass, ask, aunt, master, dance, sample, calf, etc. Strictly speaking, father belongs with the PALM set (see 7.12 below), but it is dealt with here since it behaves in the same way as after, calf, langh, last, etc. The pronunciation of words in the BATH set in Barnes's poems is strikingly varied, from /a:/ to /ja:/ to / $\varepsilon: /$.

7.7.1 The pronunciation of the vowel in the BATH set in Barnes's poems is likely to be /a:/, further forward than RP /a:/.

7.7.2 The rhymes grass/ass, grass/lass, and pa'son/cassen, which would in RP be false rhymes between a long and a short vowel, may well have been true rhymes for Barnes. As Wells points out, "vowel length is not as important phonologically in the west as it is in other parts of England. Traditionally short vowels are lengthened in many environments.... This applies particularly when ... monosyllables are phrase-final and intonationally prominent" - as they would be at the end of a line (4.3.7, p. 345). It seems probable that the short vowel in ass, lass, and cassen ('canst not') was lengthened to /a:/, making these true rhymes.

7.7.3 Barnes's spelling of master in 1844 (always miaster, replaced by meäster in the modified form of the dialect) is a clear indication of an introductory 
$i$-glide, creating the sound $/ \mathrm{ja} /$ ( with the stress on the second element) for the stressed vowel. (A similar glide is found in garden and part, see the START set, 7.21.2-3 below.)

7.7.4 On some of the words in this and the palm set Barnes himself comments, "The third [front] sound of $a$ in mate is often substituted for the first [back] one of $a$ in rather; as fäther, father; lafe, laugh; a'ter, after; bäfe, half. The author has in this case marked it $\vec{a}$ " (Diss., $\$ 23)$. To these examples may be added others from the BATH set with non-StE spelling in 1844, e.g. aunt, answer, can't, dance, glance, last, path, etc. Barnes uses several different spellings to indicate the dialect pronunciation: addition of final $-e$ (as frequently with laste); addition of a length mark over $a$ (as declared in the Diss.); substitution of ae or $\bar{e}$ for $a$ (as sometimes with faether for father and lesste for last), etc. Though the spellings vary, however, and though all these words are respelled conventionally in the modified form of the dialect, Barnes is remarkably consistent in showing in 1844 that he did not wish these words to be pronounced as in "book English". To the best of my knowledge, indeed, every instance of one of these words in 1844 is spelled in one of the ways indicating dialect rather than $\mathrm{StE}$ pronunciation. In accordance with Barnes's description I transcribe all such words with the sound / $/$ :/ (see Section 4 above).

\subsection{The CLOTH set}

The CLOTH set (Wells, 2.2.8) contains those words with short 0 in their stressed syllable that do not belong in the LOT set $(7.4$ above): in RP they have the vowel / $\mathfrak{p} /$ (like those in the LOT set); in GenAm they have the vowel $/ \mathrm{o} /$. Words in this set have short $o$ followed by /f/ or /ft/ (off, cough, soft, often, etc.), /s/ or /st/ (cross, toss, frost, lost, etc.), / / (cloth, froth, etc.), /y/ (long, wrong, etc.), or / $\mathrm{r}$ / (quarrel, sorrow, etc.). The pronunciation of words in this set has varied greatly in the SW since the mid 19th century.

7.8.1 Most words in the CLOTH set behave in Barnes's poems in the same way as those in the LOT set ( 7.4 above), retaining $/ \mathrm{p} /$ in spite of the tendency in the SW to unround the vowel to $/ \mathrm{a} /$. 
7.8.2 For quarrel, sorry, and other words with -arr- and -orr- see 7.22.5.

7.8.3 As consistently shown by rhyme, among belongs in this set for Barnes, rhyming always with words in /py/, never (as in RP) with those in / $\mathrm{y} /$.

7.8.4 As shown by both spelling (hoss or ho'se) and rhyme (always with words in -oss), horse belongs in this set for Barnes, pronounced /hps/.

7.8.5 The word soft belongs in this set, with (presumably) the normal pronunciation /spft/. The dialect form sate (occurring only in the 1844 and 1847 versions of "Poll's jack dā" and in Barnes's various Glossaries) has the vowel $/ \varepsilon /$.

\subsection{The NURSE set}

The NURSE set (Wells, 2.2.9) contains words with a stressed syllable that has the sound /o:/ in RP and /or/ in GenAm, spelled with any of several different vowels or vowel combinations followed by $-r$ : -er- (term, herd, etc.), -ear- (earn, heard, etc.), -ir-(fir, bird, etc.), -or- (worth, word, etc.), -our- (scourge, journey, etc.), or -ur-(fur, urn, etc.).

7.9.1 The vowel is pronounced / $\mathrm{a} /$, as in $\mathrm{RP}$, but the following / $\mathrm{r} /$ is also sounded (see 8.8.1), yielding / orr/.

7.9.2 The survival of the /arr/ pronunciation from eMnE is shown in Barnes's poems by the -ar-spellings in 1844 in words spelled with -er- or ear-in StE (certain, earn, earnest, German, herb, learn, serve, search, serpent, and their compounds, spelled sarten, sarta(i)nly, yarnest, jarman, yarb, larn, sar or sarve, sarch, sarpent in 1844, sometimes respelled as in StE in the modified form of the dialect), and by rhymes in which some of these words appear. The rhyme earn / burn in "Eclogue:-The common a-took in" \{supported by that of yearm / vern / burn in "Trees be company", 5-8\} suggests, however, that in his own day Barnes regarded /arr/ in earn as an acceptable alternative to /arr/, in spite of the 1844 spelling yarn. \{Similarly both rhyme and spelling in burt / smert in "Pity", 11-13, suggest /arr/rather than /arr/ in smert 'smart' $(v \cdot)$. 
7.9.3 Words from 7.9.2 with initial er- or ear-are consistently spelled with initial yar in 1844 , clearly indicating a pronunciation with initial $/ \mathrm{j} /$, thus yarn, yarnèn, yarnest, yarbs ('earn, earning, earnest, herbs'); the initial combination is less helpfully respelled in later editions as eär.

7.9.4 Metathesis of $r+$ vowel brings some words into this set in Barnes's dialect that would not otherwise belong here; thus girt and pirty or perty (often standardized to pretty in later editions), both with /a:r/, for great and pretty (Diss., §34; see 8.8.3).

7.9.5 Loss of /r/ before "a hissing palate letter" $(/ \mathrm{s} /, / \mathrm{z} /, / \theta /)$ takes some words out of this set in Barnes's poems that would otherwise be in it (see Diss., $₫ 35$, and 8.8 .5 below):
a) /o:rs/ becomes / $\varepsilon \mathrm{s} /$ in verse (spelled vess or ve'se);
b) /o:rs/ becomes / u:s/ in worse (spelled woose or woo'se);
c) /o:rst/ becomes / $/ \Lambda \mathrm{st} /$ in burst, first, nursed, worst (spelled bust, vust or vus't, nuss'd, wust);
d) / $\mathrm{a}: \mathrm{r} \theta /$ beomes $/ \varepsilon \theta /$ in earth, birth, mirth (spelled eth, beth, meth or e'th, be'th, me'th);
e) /a:r $\theta /$ beomes $/ \mathrm{p} \theta /($ or $/ \Lambda \theta /$ ) in worth (usually spelled woth or wo'th, though entered as wuth in the expanded Glossary of 1847);
f) /o:rz/ becomes $/ \Lambda z /$ in furze (spelled vurz).

7.9.6 The vowel in heard may be /arr/ as in StE (or /jarr/, with the stress on the second element, when heard is spelled heärd), or /irr/ (with the stress on the first element), as shown by rhymes with beard, feared, and sheared.

7.9.7 As shown by spelling (murn) and confirmed by rhyme, mourn is a member of the NURSE set for Barnes (with the pronunciation /mə:rn/), though it belongs with the FORCE set in StE (see 7.23.5).

\subsection{The FLEECE set}

The FLEECE set (Wells, 2.2.10) contains words with a stressed syllable that has the vowel "long $e$," pronounced /i:/ in RP and /i/ in GenAm. The 
native English words are generally spelled with ee like fleece itself (feet, seed, keen, etc.), with ea (heat, bead, mean, etc.), with $e+C+e$ (even, etc.), with ie (field, etc.), with $e y$ (key), or with $e$ alone (be, me, etc.); the words adopted from other languages (only the commonest of which are used in Barnes's dialect poems) may be spelled in any of these ways, or with ei (conceit, receive, etc.), with $i+C+e$ (machine, police, etc.), or with various other combinations, such as eo (people), oe (phoenix), ay (quay), ae (Caesar), etc. Words with this sound in current English that occur in Barnes's poems may have any of the several possible pronunciations discussed below.

7.10.1 The majority of words spelled with $e e, e+C+e, i e$, or $e$ alone and pronounced /i: in RP (descended from /e:/ in ME)—deep, see, evening, field, me, etc.- have /i:/ in Barnes's poems as in RP. But been is always spelled bin or ben in 1844, though frequently StE been is substituted in later editions. I take it that the possible pronunciations are /bin/, /bin/, or /bi:n/. The pronoun be will normally be /hi:/, but the unstressed form, 'e, is /a/ (Diss. \19). One may reasonably posit also a semi-stressed form in /ii/ or $/ \mathrm{i} /$.

7.10.2 Barnes consistently spells chime and shine with ee (see Diss., \$23), and the pronunciation with / $\mathrm{i} /$ is confirmed by rhyme.

7.10.3 Most words that had / $\varepsilon$ : in ME (generally now spelled with ea) have developed /ii/ in RP, so that meat, sea, and bean have become homophones of meet, see, and been. Where Barnes gives no indication to the contrary, whether in spelling, rhyme, or grammatical commentary, it is reasonable to assume that the pronunciation is /i:/; but some words spelled with ea and pronounced with /i:/ in RP are pronounced in other ways in Barnes's poems; a number of them appear to fluctuate between /i: and an alternative pronunciation, as discussed below.

7.10.4 As Barnes himself remarks in $\$ 19$ of the Diss., "For the first long close sound of ea as in beaver, dream, the second is often substituted, as bever, drom...." That is to say, in Barnes's dialect the highest long front vowel, /i:/, is often replaced by the vowel immediately below it, which he describes in $\$ 16$ of the Diss. as "e long in the western dialects" and which he calls elsewhere "the Dorset e"” (1863 Grammar, p. 11) or "the Dorset ê" (1886 
Glossary, p. 1). The sound intended appears to be /e:/ (often indicated by the spelling $\bar{e} a$ or $\bar{e}$ ), but Barnes's practice in both spelling and rhyme suggests that pronunciations with /i: and /e:/ were both acceptable in his dialect. Accordingly I transcribe the vowel in words spelled with ea in StE as /e:/ when Barnes spells it with $\bar{e} a$ or $\bar{e}$, but otherwise as /i:/. \{Where, however, words with éa are rhymed with words having ea or ee, as in plèase / vleas in "Bob the fiddler" and éase / trees in "Evemèn in the village" (both in 1844), I transcribe both words with/i:/. But ease is also spelled yease in "The Church an' happy Zunday" (1844), indicating initial / $\mathrm{j} /$; and several times in 1879 it's spelled eäse, and rhymed with words that have the sound /ia/. There appear to be several possible pronunciations for ease: /i:z/, /e:z/, and /iəz/, with or without initial $/ \mathrm{j} /$ in each case.\}

7.10.5 The spelling $\bar{e}$ appears in 1844 not only in words spelled with ea in StE but also in a small number of other words with $/ \mathrm{i}$ / or $/ \varepsilon /:$ bèn't (be not, i.e. 'are not'); crēp (creep); mèsh(y), mashy (moss, mossy, from OE meos, see OED tmese, $\left.n^{1}{ }^{1}\right) ; n \bar{s} h$ (nesh, i.e. 'soft, tender'). In all these instances the vowel is presumably /e:/.

7.10.6 The verb drive is almost always spelled drève in 1844 and 1847 (thereafter usually dreve), indicating that it has /e:/.

7.10.7 Other commentators also note the preference for /e:/ over /i:/ in SW dialects in many words that have /i:/ in StE.

7.10.8 A handful of words in 1844 are spelled with eä: afeärd, beäns, beänhan' (bear in hand, i.e. 'think, believe'), beäs (beasts), beät, bleät, cheäk(s), cleän, deäl, feäst, geät(e) (gate), heärd, Jeän, leäd, leän, leäp, leäse or leäze (a stocked pasture "in distinction from a mead which is mowed," 1844 Glossary), leäst, leäve, leäzer (gleaner), meäd(s), meän(èn), and sheärs. I transcribe this sound throughout as /ia/. (On the similarity between this diphthong and that in words belonging to the FACE set see 7.11.2; on the instability of the diphthong in beat and mead see 7.11.3.)

7.10.9 The rhyme with leäze in the second stanza of "Sweet music in the wind" ("I'll think how in the rushy leäze / O' zunny evemens jis' lik' theös, / 
In happy times I us'd to zee / Thy comely shiape about thik tree" shows that the vowel of the demonstratives theös (1844) and theäse (later editions), both meaning this or these, has the same sound as that discussed in the preceding paragraph, /iə/.

7.10.10 Barnes invariably spells heat in his dialect poems as het and rhymes it with words ending in /et/; the vowel is thus clearly not the /i:/ of StE but $/ \varepsilon /$.

7.10.11 Keep, meet, and week may be spelled with either ee or $i$ in 1844 . Although keep is rhymed only on the sound /i:p/ and meet on /itt/, week is rhymed on both /i:k/ and / $\mathrm{ik} /$. The rhymes on / $\mathrm{ik} /$ are kept in later editions, even when week is respelled as in StE. The logical conclusion is that in these words pronunciations with /i:/ and / $/$ / were both acceptable in Barnes's dialect. In transcribing these words, accordingly, I use $/ \mathrm{i}(\mathrm{:}) /$ when the spelling is with $e e$, and /I/ when it is with $i$.

\{Seem is usually so spelled, and rhymes with team, cheem, scream, dream, etc.; but it is also occasionally spelled sim. I transcribe it accordingly as /sim/ when it rhymes on the sound /i:m/, / $\mathrm{si}(\mathrm{i}) \mathrm{m} /$ when the spelling is seem outside rhyme, and /sim/ when the spelling is sim. Similarly sweet, spelled with $i$ in swithearts in the second stanza of "The woody holler" (1844), but elsewhere always with ee, and rhymed with meet, veet, and sheet.\}

7.10.12 The current pronunciation of key, sea, and tea in StE makes them members of the FLEECE set; historically, however, they belong with the FACE set. They are discussed in 7.11.7 and 7.11.9 below.

7.10.13 In Barnes's dialect poems cheek is never spelled with ee as in StE but almost always with $e \ddot{a}$, suggesting that the dialect form is derived from the West Saxon céace, in contrast to the StE form, which is from Anglian céce. Barnes's consistent avoidance of the spelling cheek confirms that vowel is never /i:/; his favoured spelling, with $e \ddot{a}$, implies that the pronunciation will always be /iə/ (see 7.10.8 above).

7.10.14 The usual spelling of weak and its derivatives in Barnes's poems is with $e a$, as in StE; occasionally with $\bar{e} a$ or $e \ddot{a}$. Nowhere, in spite of its usual 
StE spelling, does weak rhyme with a word that has, indisputably, the vowel /i:/ as in RP. Since /i:/ cannot be conclusively ruled out, however, the possible pronunciations appear to be /we:k/, with the Dorset $\bar{e}$ (see 7.10.4), /wiək/, as in the rhymes with cheäk, and /wi:k/, as in RP.

7.10.15 The word peony appears rarely in Barnes's dialect poems: once, spelled piny, once, in the plural, spelled pinies in both early and late editions. In present-day recordings it is rendered variously as /parni/, /pini/, and /pini/, all of which would appear possible from the 18th-century spellings piney, piny, pinny, and peeny recorded in OED for the south of England. Barnes's spelling perhaps (but not certainly) implies /pə:Ini/ (see 7.16.1).

\subsection{The FACE set}

The FACE set (Wells, 2.2.11) contains words with a stressed syllable that has the vowel "long $a$," the diphthong /er/, in both RP and GenAm. This may be spelled in a number of different ways $(a+C+e, a i$, ay, ei, ey, eigh, etc.), representing several different origins; these different origins tend to have different pronunciations in Barnes's dialect, as shown below.

7.11.1 The commonest spelling for this set in $\mathrm{StE}$ is $C+a+C+e$, as in bake, case, shape, etc. Barnes's normal spelling for the $a$ in this combination in 1844 and 1847 is ia (biake, ciase, sbiape, etc.); in later editions the ia is replaced throughout by eä (beäke, ceäse, sheäpe, etc.). As explained in 7.11.2, I transcribe this sound as $/ \mathrm{j} \varepsilon /$.

7.11.2 The similarity between the diphthongs in words spelled with $i a$ and $e \ddot{a}$ in 1844 calls for further comment. Not only is Barnes's initial description of the diphthongs (in $\int \$ 19$ and 21 of the Diss.) the same, but his decision to spell them in the same way (with $e \ddot{a}$ ) in later editions suggests perhaps that the difference in pronunciation is too slight to be worth bothering about. If this is indeed the case, it makes homophones or very near homophones of such pairs as bane (1844 biane, later editions beäne) and bean (always beän), lane (1844 liane, later editions leäne) and lean (always leän). Nevertheless, with the exception of beat, gate, and mead, which appear to be special cases (see 7.11.3), Barnes avoids rhymes between words of the bane type and those of 
the bean type. It is clear, then, that the distinction between the two diphthongs was important to Barnes.

This distinction involves not only the quality of the second element of the diphthong $(/ \varepsilon /$ in the one case, $/ \partial /$ in the other) but also the placement of stress. In words of the bean type, where the second element is $/ \partial /$, the stress will be on the first element, since the second element, schwa, is by its very nature unstressed. Thus beän, with a falling diphthong, will sound similar to StE bean, but with a slight off-glide following the initial $/ \mathrm{i}(\mathrm{i}) /$; in ordinary script its sound might be represented as "BEEun." In bane and other words from the face set, in contrast, there is evidently a rising diphthong (with the stress on the second element), as shown by the rhymes with words such as let, wet, neck, etc.; in ordinary script the sound of bane might be represented as "biEN" or "byEN." (To distinguish between these falling and rising diphthongs in this guide I use / $\mathrm{i}$ / as the first element of a falling diphthong and $/ \mathrm{j} /$ for the first element of a rising diphthong, hence the transcriptions / bion/ for bean and /bjen/ for bane.)

7.11.3 The words beat, gate, and mead appear to be special cases where the diphthong is sufficiently unstable to allow rhymes with words from different sets. Beat, always spelled beät, will normally be expected to have the diphthong /iə/ (see 7.10.8); it is rhymed, however, only with gate (several times) and wet, the second rhyme clearly suggesting that the diphthong is $/ \mathrm{j} \varepsilon /$. Gate (spelled giate, gbiate, geät, or geäte) rhymes not only with let and wet, but also with beat and treat. The rhymes with let and wet are to be expected, assuming that the diphthong in gate is normally $/ \mathrm{j} \varepsilon /$; that with treat, however, suggests that the diphthong is /ia/. As for the rhymes between gate and beat themselves, it would appear that the diphthong in both words may be either /iə/ or /je/. Mead, always spelled meäd, shows more flexibility than beät: it rhymes not only with lead, snead, and bead (all with the diphthong /iə/) but also with zeed and reed $(/ \mathrm{i}$ : $/)$, homestead $(/ \varepsilon /)$, and shade $(/ \mathrm{j} \varepsilon /)$, suggesting three possible pronunciations for mead: / $\mathrm{mird} /, / \mathrm{mi}: \mathrm{d} /$, and $/ \mathrm{mj} \varepsilon \mathrm{d} /$.

7.11.4 The rhyming of again (spelled agen, ageän, agiën, or agaen) with words ending in both -en and -ane may suggest that again has the same two 
pronunciations in the dialect as in StE, /ogen/ and /ogern/. But the rhymes with words in -ane are on /jen/ (see 7.11.1-2); again is not rhymed with words ending in -ain, which would have the sound /ærn/. The possible pronunciations of again in Barnes's dialect are /əgen/ and /ogjen/ (the same rhyme sound, with or without an introductory $i$-glide).

7.11.5 When the vowel is in initial position, as in able, acbe, acorn, acre, ale, ape, apron, the spelling of 1844 is invariably ya- (yable, yache, etc.), suggesting that in initial position the introductory $/ \mathrm{j} /$ has some prominence; the spelling is changed in later editions to eä (eäble, eäche, etc.). Barnes's two spellings of acorns in 1844 (yacors and yakkers, both replaced by eäcorns in later editions), suggest two possible pronunciations, /jekərz/ and /jakərz/.

7.11.6 One group belonging to the FACE set contains words spelled with $a i$, $a y, e i, e y$, or eigh (excluding those words with ay or ey discussed in 7.11.7, 8, and 10). Barnes's own comment on this group in $\$ 22$ of the Diss. is as follows: "The diphthongs ai or ay and $e i$ or $e y$, the third long [front] sound as in May, hay, maid, paid, vein, neighbour, prey, are sounded,--like the Greek [i.e. Classical Greek] $a i$, - the $a$ or $e$ the first [back] sound as $a$ in father and the $i$ or $y$ as $e e$ the first [front] sound. The author has marked the $a$ of diphthongs so sounded with a circumflex; as Mây, hây, mâid, pâid, vâin, nâighbour, prây." In later editions $a \ddot{i}$ and $a \ddot{y}$ are substituted for $\hat{a} i$ and $\hat{a} y$ (Mä̈, bäj, maïd, païd, vaïn, naïgbbour, etc.). Barnes's description of the diphthong as a combination of /a:/+/i:/ (or, with short vowels, /a/+/i/ = /ai/) makes it sound very similar to the /aI/ diphthong of RP high, pride, cry, etc. In current recordings of Barnes's poems read by conservative dialect speakers, however, the diphthong sounds closer to the /æI/ of Cockney mate or Australian G'day. I transcribe the diphthong in this group, accordingly, as /æI/.

The inclusion of plait in this subset, as implied by the spelling plaited (/plæitrd/) in the third stanza of "Pentridge by the river," may be surprising to RP speakers, for whom the word belongs in the TRAP set; but Barnes's listing of the word in the 1854 Philological Grammar as an example of the "third long sound" in proto-RP, along with main, rain, strait, etc., is supported by the detailed etymological note in OED, showing that the current pronunciation is recent. 
The pronunciation of aye in Barnes's poems is uncertain. OED distinguishes between aye 'ever' (RP/eI/ or / $\mathrm{\Lambda I} /$ ), from $\mathrm{ON} e i$, ey, and aye 'yes' (RP / $\mathrm{\Lambda I} /$ as in I, eye, etc.), of unknown origin. The rhyme of aye 'ever' with away in "The geäte a-vallén to" suggests /e:/ or /æI/ in Barnes’s dialect for the former (see 7.11.8); that of aye 'yes' with paÿ in line 21 of "Bleäke's house in Blackmwore" suggests /æI/ as in the first paragraph of this entry for the latter. I transcribe both words as $/ æ I /$.

7.11.7 A second group containing words spelled in StE with ay or ey (and their derivatives) forms a subset of its own. Its members are clay, day, fay ( $v$. 'succeed, prosper'), lay, say, way (but see further 7.11.8), grey, key, and whey, in all of which the ay or $e y$ is descended from OE $a g$ or $e g$, with the vowel long or short. (The final $g$ in these words in OE was pronounced not $/ \mathrm{g} /$ as in $\operatorname{dog}$ but $/ \mathrm{j} /$ or $/ \mathrm{i} /$ as in present English day.) Barnes's spellings for these words, in addition to the StE spelling, include $a$, $\bar{a}$, ae, àe, $a$, and $\bar{e}(c l \bar{a}$; $d a, d \bar{a}$, dae, dàe; làe, lae; ₹ā, zae; gré (in grègole 'bluebell', later respelled gragle); and whè; for way see 7.11.8); except in vary rare instances they are not spelled with ây (1844) or aij (later editions) and do not rhyme with words so spelled, discussed in 7.11.6. Barnes notes that day and whey have the Dorset $\bar{e}$ (1886 Glossary, p. 3), and I normally therefore transcribe the vowel in this group of words as /e:/ (see 7.10.4 above); day and fay, however, are exceptional in that they are rhymed both with words in this group and with words in 7.11.6, suggesting the co-existence in the dialect of the pronunciations /de:/, /fe:/ and /dæI/, /fæI/.

Whereas laid and said (OE lagde and sagde), the past tenses of lay and say, are the same in form (apart from the initial consonant), their pronunciation in RP has diverged, laid retaining the vowel of the infinitive and said normally being shortened to /sed/. Rhymes show that in Barnes's dialect this divergence has not happened: said (spelled zed, zaid, or zaïd) is pronounced as in RP and laid (though spelled as in StE) has evidently undergone the same shortening, since it rhymes only with words ending in $/ \varepsilon d /$.

The current pronunciation of key in StE, with /i:/, makes its presence in this group seem odd, but this pronunciation is, as OED points out, 
"abnormal"; and "that key had the same vowel [as clay, grey, etc.] in ME. is proved not only by the frequent spelling kay, but by its constantly riming with day, way, say, play, etc. This was evidently the standard pron[unciation] down to the close of the 17th c.; Dryden has the rime with way more than once in one of his latest works (1700)" (OED, key, $\left.n .{ }^{1}\right)$. See further 7.11.9.

7.11.8 The pronunciation of way and away is very unstable. Historically these words belong with the subset in 7.11.7, and where they are spelled with ay without diacritics (as is usually the case) and/or where they are rhymed with a word from the clay subset, my assumption is that that their vowel is the Dorset $\bar{e}, / \mathrm{e}$ /. But they are occasionally spelled with aj in later editions and frequently rhymed with words from the May, hay subset in 7.11.6, showing that, like day and fay, they have an alternative pronunciation with /æI/. They are also sometimes spelled with oy, both outside rhyme (particularly in 1844) and in rhymes with boy, showing the coexistence of a third pronunciation with /oiI/ (see further 7.17.1, 7.17.4). We thus have three pronunciations for the vowel of way and away in Barnes's poems: /e:/, /æI/, and /ə:I/.

Always, though derived directly from way, appears to behave differently, doubtless because the major stress is normally on the first syllable. To the best of my knowledge it is never spelled with $\hat{a} y$, ayj, or $y$, and does not occur in rhyme. In the absence of deviation from the StE spelling always and of rhymes suggesting otherwise, I take it that the vowel in the second syllable is normally /e:/. But heavy stress on the first syllable may lead to some reduction of the vowel in the second syllable, as suggested by the spelling alwiz in line 8 of the 1844 version of "The milk-mâid o' the farm". Here the vowel in the second syllable may be $/ \mathrm{I} /$, as implied by the spelling; alternatively it may be further reduced to $/ \mathrm{\partial} /$.

7.11.9 Sea and tea (though their vowels are not from the same source) might be considered honorary members of the group in 7.11.7. Barnes's rhymes indicate clearly enough that the usual Blackmore Vale pronunciation of tea was /te: / it is reasonable to assume that the rhyme tea/key would have been on the sound /e:/, since key rhymes elsewhere only with day and grey, and tea only with lay); they show also that pronunciations of sea as /se:/ and as /si:/ 
were both current in his dialect (as they were in StE for Cowper, Dryden and others), allowing rhymes on either vowel.

7.11.10 The word they has many different spellings in 1844: tha, tha', they, they, tha $\bar{a}$, thae, thäe (rare), the (rare), and the (rare); in later editions the only spelling is they. The spellings other than tha and tha', and the sole instance in which they appears as a rhyme word, rhyming with day in "The girt wold house o' mossy stuone" (in 1844 and 1847 only), all point towards the Dorset $\bar{e}$ (see 7.10.4 and 7.11.7 above). It is possible that tha and tha' represent an unstressed form, /ðə/ (cf. ya and da for you and do, 7.15.5); but the occasional occurrence of tha as a demonstrative pronoun in positions where it would be expected to carry some stress makes this unlikely. I therefore transcribe all forms of they as /ðe:/.

7.11.11 Three words with ea spellings that belong in the FACE set in StE are break, steak, and great. Barnes's rhymes suggest that break (occasionally spelled bréak or brè $k$ in 1844) has two possible pronunciations in the dialect, one with /e:/, the Dorset $\bar{e}$ (see 7.10.4 above), the other with /je/, like words with -ake (see 7.11 .1 above). The spelling steäk in the 1847 version of "Liady-day.." implies /stiək/ (see 7.10.8), but the 1879 re-spelling, steäke, implies /stjek/ (see 7.11.1-2). Great becomes by metathesis girt (/gə:rt/, see 7.9.4 above).

7.11.12 Words derived from French containing the sequence $a+$ nasal consonant (angel, chamber, change, danger, strange, and stranger) form a separate subset. In 1844 Barnes spells these words consistently with $a+$ double consonant: anngel, chammer, channge, dannger, strannge(r); these spellings are replaced by the StE spellings in 1879 with the exception of chammer, which is retained in the word's sole occurrence, in the penultimate stanza of "Polly be-èn upzides wi' Tom". I transcribe all words in this subset (except Grange) with /a/, thus /andzəl/, /t famər/, etc.

Grange, which appears once only, in "Easter time [b]" (1844) (= "Easter Monday," 1879), is spelled as in StE even in 1844, both spelling and pronunciation being perhaps influenced by its status as a proper name. Its pronunciation is therefore presumably /gre:nd3/ (see next paragraph). 
7.11.13 Words derived from French containing age pronounced / eId3/ in RP (age, cage, rage, stage) form another subset. Since these words always have their StE spelling in Barnes's poems (never the $i a$ or eä forms discussed in 7.11.1), I take it that the vowel is the undiphthongized third long front vowel in Barnes's table of the pure vowel sounds in "national English", as set out in $\$ 16$ of the Diss. I transcribe the vowel in these words, accordingly, as /ع:/.

7.11.14 In the surrounding districts, as in the Blackmore Vale, there is much variation in the pronunciation of long $a$.

\subsection{The PALM set}

The PALM set (Wells, 2.2.12) contains words with a stressed syllable that has the vowel /a:/ in RP and /a/ in GenAm, excluding those where / r/ follows the vowel (for which see the START set, 7.21 below). PALM words "belong phonetically with START (and BATH) in RP, but with LOT in GenAm" (Wells, 2.2.12, p. 143). Most words in this set are recent borrowings from foreign languages, and do not occur in Barnes's poems; of the native English words (and exclamations) listed by Wells, the only ones that occur in Barnes's poems are palm itself, calm, father, hah, and burrah.

7.12.1 There is no reason to suppose that the stressed vowel in palm, calm, bah, and hurrab does not have the same pronunciation in Barnes's poems as that of the majority of words in the BATH set, i.e. /a:/ (see 7.7.1).

7.12.2 For a discussion of the stressed vowel in father see 7.7.4.

\subsection{The THOUght set}

The THOUGHT set (Wells, 2.2.13) contains words with a stressed syllable that has the vowel /o: in RP and / / or /a/ in GenAm, excluding those that belong with NORTH (7.22), or FORCE (7.23), or CLOTH (7.8). The StE spellings of words in this set include anght (tanght, canght, daughter, etc.), au $+C$ (cause, haul, baunt, sauce, etc.), aw alone and aw $+C$ (draw, law, saw, crawl, etc.), all and al (all, fall, appal, etc.), alk (chalk, talk, walk, etc.), al $+C$ and aul $+C$ (salt, false, fault, etc., also pronounced / $/ \mathrm{p} /$ in RP, and bald), ought (ought, bought, fought, etc.), and assorted other words (broad, abroad, water). 
Of this set of words Barnes says, "The second long [back] sound, as of $a$ in fall and of aw in jaw, is sometimes turned into the third [front] one $\bar{a}$, as $v \bar{a} l$, in some parts val, fall; $j \bar{a}$, jaw; strā, straw: though brought becomes brote, and fought becomes diphthongal, foüght, of the third and fourth [back] sounds" (Diss., \$24; see also 1863 Grammar, p. 13; 1886 Glossary, p. 4). Where there are no indications to the contrary, we may assume that the vowel in this set is / $\mathrm{a} /$ as in RP. The several possible variations are discussed below, in subsets according to the StE spelling of the words in each subset.

7.13.1 Words with the sound /o:l/ in RP (all, fall, small, haul, crawl, etc.). Whereas these words all have their current spelling in later editions, Barnes rarely uses it for them in 1844 . There his usual practice is to reduce final $-l l$ to $-l(a l, v a l$, smal, etc.) and to omit $u$ and $w$ (hal, spra'l, etc.); occasionally he uses the spelling âl (as in squal / crâl in the 1844 version of "Hây-miakèn"); sometimes he indicates the alternative pronunciation with $\bar{a}$ noted in 7.13 above. I take the $\bar{a}$ spelling to denote / $\varepsilon$ :/ as in fäther, etc. (see 7.7.4); but what is meant by the reduction of $-l l$ to $-l$, the omission of $u$ or $w$, and the occasional use of the spelling $\mathrm{al}$, on which Barnes makes no comment other than that fall is "in some parts val"? Assuming that the pronunciation in proto-RP was /o:l/, the likelihood must be that Barnes's spellings with al, a'l, and $\hat{a} l$ indicate the unrounded pronunciation /a:l/. Accordingly I transcribe the sound in this group as / o:l/ where Barnes uses the StE spelling in 1844, as /a:l/ where the spelling is al or a'l (as normally in 1844), and as / $\varepsilon: 1 /$ where this pronunciation is suggested by the spelling with $\bar{a}$ or by rhyme. Almost is normally spelled a'most in both early and late editions; I take the $a$ ' to represent a reduction from /a:l/ to /a:/, the whole word being pronounced /a:mo:st/ when there is some stress on the second syllable, /a:most/ when there is none.

7.13.2 The subset containing words with alk behaves in much the same way as the previous subset, showing the same three possible pronunciations for the vowel. In 1844 words in this subset are almost always spelled with $\bar{a}^{\prime} k$, $\bar{a}^{\prime} k e$, or $a^{\prime} k e$, implying / $\mathrm{k} \mathrm{k} /$, but occasionally with $a^{\prime} k$, implying /a:k/, or 
auk, implying / o:k/. Words in this subset rhyme only with other words from the same subset.

7.13.3 The subset containing words with $a u(+C)$ or $a w(+C)$ shows similar variability. The preferred spellings of haunt, saunter, mawn ('basket'), -daw, draw, jaw, law, saw(-pit), and straw in 1844 ( $\bar{a}, \bar{a} e, a e)$ imply the pronunciation $/ \varepsilon:$, with the variants $d r a$ and $l a$ ' in draw and law suggesting the alternative /a:/. Barnes's contribution to EEP has proto-RP /o:/ in law but /e:/ in straw and jaw; on the other hand his spelling of sauce as sass in 1844 (alone and in the derivatives saucepan and saucy) implies /a:/, as does the rhyme sass/pass. \{I take dake (in "The witch," 1844) to be variant of dawk (see EDD dake, v. and dawk, $v^{1}$.) and accordingly transcribe it as $\left./ \mathrm{d} \varepsilon: \mathrm{k} /.\right\}$

7.13.4 Barnes's spelling of because in 1844 (always bekiaze or bekiase, never the $\mathrm{StE}$ because that is used invariably in later editions) shows both that there is an $i$ - or $y$-glide following the velar $/ \mathrm{k} /$ (see 7.21.2), and that the vowel in -cause is the / $\varepsilon$ : / sound of $a+C+e$ (see 7.11.1). My transcription is thus always /bikje:z/.

7.13.5 The spelling anght does not occur in the poems of 1844, though in later editions it is found in daughter, caught (cf. 1844 catch'd), taught, and naught (besides laughter and draught, which belong in the BATH set, 7.7). The sole occurrence of -aught in rhyme that I know of (a-tanght / thought in "Daniel Dwithen, the wise chap") shows Barnes making use in his third dialect collection of StE / o:t/. In daughter, however, Barnes's spellings in 1844, daeter, dāter, and dàtter (the last retained in most instances in later editions of the first collection, but elsewhere replaced by daughter), together with the rhymes in "The farmer's woldest daeter", show that his normal pronunciation in the dialect of the Blackmore Vale was /de:tər/, with / $\varepsilon$ : as the vowel of the stressed syllable (see 7.7.4).

7.13.6 Present-day readers may assume that water will follow daughter in having / $\varepsilon$ : in Barnes's poems, since the stressed vowel in both words is the same in StE. But their vowels have different origins in OE; they have reached RP / o: / by different routes; and Barnes's practice shows that the vowels were pronounced differently in the Blackmore Vale. He invariably 
uses the StE spelling, water, in both 1844 and later editions, and on the sole occasion I know of when water is used in rhyme (as opposed to a nonrhyming refrain) it rhymes with thought her (in “Zummer an' Winter"), showing that the stressed vowel in water is $/ \mathrm{o} /$.

7.13.7 Rhymes with words such as grow'd, know'd, and road, together with the 1844 spellings with -ode (often retained in later editions) show that the vowel in broad and abroad, like that in brought (see next paragraph), is /o:/ as opposed to RP / o:/.

7.13.8 Barnes's comments on brought and fought in $\$ 24$ of the Diss. (quoted at the head of this section) draw attention to anomalies in the subset containing words with ought. An examination of his spellings and rhymes leads to the following observations:

a) ought, nought, sought, thought, and wrought are invariably spelled with ought and rhyme only with words spelled with ought or aught: they are pronounced with / o:t/.

b) brought may be spelled brought (in which form it rhymes frequently with thought): its pronunciation in this case is /brot/. But it may also be spelled brote (the preferred spelling in 1844), or brote, or bro't (in one of which forms it rhymes with throat and smote): in these instances the pronunciation is /bro:t/, in line with Barnes's comment in the Diss. Similarly bought rhymes only with ought and thought, but outside rhyme (in 1844) it is also spelled bote or bo'te: like brought, therefore, it may be pronounced with either / o:t/ or / o:t/.

c) fought is spelled foüght or fönght; it rhymes only with words in -out, bearing out Barnes's comment that it becomes diphthongal. The diphthong is not, however, RP / av/ but Blackmore Vale /arv/ (see 7.18.1, 7.18.3).

d) flought is found only in "Riddles". It does not appear with this spelling in the 1863, 1879, or 1886 Glossaries, or in OED or EDD. It is perhaps to be identified with "Flout, a flinging, or a blow of one" (1879 Glossary), which would make sense in the context, in which Anne's cow "het the pail a flought, / An' flung [her] meal o' milk half out"; alternatively a flought may perhaps be a late survival of 
the predicative adjective aflocht "in a flutter, agitated," which would make equally good sense in the context (although the three occurrences in $O E D$ are all Scottish and all date from the 16th century). Whatever the meaning of the word, however, the rhyme with out shows that it is pronounced with the diphthong / a:v/ (see 7.18.1, and cf. fought, above and 7.18.3).

\subsection{The GOAT set}

The GOAT set (Wells, 2.2.14) contains words with a stressed syllable that has the vowel /ov/ in RP and /o/ or /ov/ in GenAm, traditionally called "long $o . "$ The StE spellings of words in this set include final $o(g o, s o)$, oa (oak, road), oe (toe, sloe), o+C+e (rope, home), ol (old, roll), oul (soul, moult), ow (know, own), ough (though), etc.

This sound was not a diphthong in proto-RP, but remained a pure vowel, /o:/. Of words in this set Barnes remarks, "The third long sound of $o$ and $o a$ of English words such as bold, cold, fold, more, oak, rope, boat, coat, becomes the diphthong wo of the fourth and third short [back] sounds in the Dorset dialect, in which those words are buold, cuold, vuold, muore, woak, ruope, büot, cüot" (Diss., \$27). Several questions, discussed in turn below, arise from this statement: Does this diphthongization affect all words with long 0 all the time? If not, what are the rules (if any) governing which words will or will not have diphthongization? What is the sound of the diphthong described? Does it have the same sound initially as internally?

7.14.1 The wording of Barnes's statement above may imply either that long 0 is always diphthongized in the Blackmore Vale in the way described and that the words listed are merely offered as examples, or, on the contrary, that there are certain words in the Blackmore Vale-words such as those listedin which long $o$ is diphthongized, whereas in other words it remains the monophthong /o:/. An examination of Barnes's spelling practice in 1844 shows that long $o$ is not diphthongized in all words, and that the same word may sometimes have a monophthong, sometimes a diphthong-assuming, that is, that Barnes consistently indicates the diphthongal pronunciation by inserting $u$ or $w$ before the 0 . Barnes's later comments in the 1863 Grammar 
show beyond doubt that long $o$ is not diphthongized in all words: "Dorset is, in many cases, more distinctive than our book-speech, inasmuch as it has many pairs of words, against single ones of our books, and gives sundry sounds to other pairs, that, in English, are of the same sound; so that it withholds from the punster most of his chances of word-play. 'The people told the sexton and the sexton toll'd the bell' is in Dorset 'The people twold the sex'on, an' the sex'on toll'd the bell'” (p. 31, repeated more or less verbatim in the 1886 Glossary, p. 29).

7.14.2 But is it possible to predict when long 0 will be diphthongized and when it will not? The current spelling in StE appears to be irrelevant: many words with $o a$ are diphthongized but others are not; many with $o$ alone are not diphthongized, but some are. The only fixed rule governing diphthongization that I have been able to detect is that, except in gold (see 7.14.5 below), the vowel in -old is always a diphthong (buold, cuold, wold, etc.). Elsewhere the phonetic environment evidently has some effect: after syllable-initial $m$ - or $l$ - the sound is normally a diphthong (but not necessarily so after $\mathrm{cl}$-). Etymology appears to have little or no influence. In these circumstances the only safe course is to trust Barnes's spelling; accordingly I show a diphthong when the $o$ is preceded by $u$ or $w$ and a monophthong when it is not.

7.14.3 As for the sound of the diphthong, when it occurs, Barnes's description (quoted above) suggests that it is a combination of $/ U /$ as in crook and $/ \Lambda /$ as in lull, i.e. $/ U \Lambda /$. Rhymes such as those of coat with cut, shut, and strut and of bone, stone, and alone with words ending in / $\mathrm{\Lambda n} /$ suggest that this is an accurate description. But other rhymes, such as those of hold and rolled with old, cold, mould and other words spelled with no or wo suggest rather that the second element of the diphthong is $/ \mathrm{o}(:) /$, and that of stone with shone suggests that it is $/ \mathrm{p} /$. In his other grammars, moreover, Barnes gives different descriptions of the sound. In the 1863 Grammar (p. 14) it is a combination of /u:/ as in food and /o:/ as in rope (if both elements are long), or /uo/ (if both elements are short). In the 1886 Glossary (p. 14), on the other hand, it is a combination of / $\mathrm{u}$ / / as in food and /o:/ as in earth, or /uə/ (if both elements are short). These apparent inconsistencies on Barnes's part 
doubtless reflect a genuine instability in the pronunciation of the diphthong. On balance it seems best to transcribe the diphthong as/ur/, since the weight of evidence favours this interpretation rather than others, and since a second element with schwa is flexible enough to allow some latitude in rhyming including occasional rhymes between diphthongized and nondiphthongized long $o$, as in the third stanza of "Keepèn up o' Chris'mas," where cuold and scuold (1844) are rhymed with roll'd\}.

7.14.4 Barnes's use of different spellings for the diphthong in 1844 according to whether it is internal or initial (uo internally, wo initially, as in woak, woats, woaths, wold, i.e. 'oak, oats, oaths, old') suggests that there is a clear difference between the sounds; his decision to abandon the $u$ spellings in later editions and to use wo in all positions may suggest, on the other hand, that any difference is minimal. Uncertainty about the pronunciation of the diphthong when it occurs in initial position is apparent from audio recordings made by current dialect speakers: some give the initial $w$ - full value, pronouncing old as in Stow-on-the-Wold and oak as in woke up; others ignore the $w$ - entirely, giving these words their RP pronunciations /ould/ and /ouk/. Accordingly I transcribe all internal occurrences of the diphthong in Barnes's poems as /uə/; in initial position, however, I use /(w)uə/ to reflect the possibility of realizations with full initial $/ \mathrm{w} /$.

7.14.5 Gold and golden are invariably spelled with oold in Barnes's dialect poems, both early and late. (No other word is spelled with oold.) Gold appears in rhyme only twice (neither occurrence in 1844): on both occasions it rhymes with a word containing the diphthongal / ue/ (vwold and twold). Barnes's spelling implies the pronunciation /guild/; his rhymes, on the other hand, imply /guold/. There is evidently some latitude. I transcribe both words with /u:/ except for the two instances of /uə/ in rhyme.

7.14.6 Ago, go, no ('not any'), so ('and so, therefore'), sloe, and toe are almost invariably spelled with oo or ooe in both early and late editions. I know of only four instances in 1844 in which words in this subset are spelled with a single 0 : go (rhyming with flue) in "The settle an' the girt wood vire"; "no stuone" in "The brook that runn'd by gramfer's"; "no cal" in "Farmer's sons"; and "no scope" in "Eclogue:- Two farms in oone." In every case 
except the last (which looks like an oversight) the spelling is changed in later editions to oo. Rhyme evidence confirms that the vowel in these words is always /u:/. Barnes consistently maintains a distinction between no (the opposite of yes) and noo ('not any'). The former, /no:/, is always spelled no, and rhymes with words ending in /o:/; the latter, /nu:/, is invariably noo (e.g. seven times in the final stanza of "Zunsheen in the winter"). The distinction is nicely brought out in the first and third lines of "The farmer's woldest daeter": “No. No. I bēn't arinnen down / The pirty mâidens o' the town; / Nar wishèn ō'm noo harm" (1844, my italics). Similarly Barnes distinguishes between so (/sə/ or /so:/, according to emphasis, 'to this extent') and zoo (/zu:/ 'and so, therefore').

7.14.7 Forms derived from go do not necessarily keep the /u:/ of the infinitive. For going Barnes's normal practice leads us to expect the form gooèn; in his poems, however, the spelling is always gwâin (1844 and 1847) or gwaïn (later editions), i.e. /gwæin/ (see 7.11.6). To the best of my knowledge goes occurs only twice, in two successive lines of "The shy man": "The bride wer a-smilèn as fresh as a rwose, / An' when he come wi' her, an' show'd his poor nose, / All the little bwoys shouted, an' cried 'There he goes,' / 'There he goes." " Here the rhyme with nose indicates standard proto-RP pronunciation, /go:z/.

7.14.8 There is nothing to indicate that words ending in -ow pronounced /ov/ in RP do not normally have the expected proto-RP monophthong, /o:/. In the unstressed second syllable of a disyllable, however, this is generally weakened to /or/, as Barnes points out in the last sentence of $\$ 27$ in the Diss.: "ow at the end of a word as fellow, hollow, mellow, pillow, yellow, mostly become er, making those words feller, holler, meller, piller, yoller." Although $/ \mathrm{r} /$ is normally retained in the dialect (see 8.8.1), Barnes's spelling in the 1844 poems shows that in unstressed endings such as this it may be lost (e.g. in narra and arra for narrow and arrow in "Eclogue: Viairies"). The safest transcription is accordingly / $\mathrm{\partial}[\mathrm{r}] /$. The past tense of verbs with short 0 in the first syllable, however, is different again. In 1844 Barnes 
consistently spells the ending of the past tense of follow and bollow ('shout') ied or -eed, indicating the pronunciations /vplid/ and /hplid/.\}

7.14.9 The words ending in $o$ or oe listed in 7.14.6 appear to be the only ones with the vowel $/ \mathrm{u}: /$. There is no reason to suppose that other words with this spelling (echo, foe, woe, etc.) do not have proto-RP /o:/, and rhymes with stressed -ow confirm that their vowel is /o:/.

7.14.10 In 1844 over is always spelled awver, a form that occurs only once elsewhere, in the awverzeer in the early eclogue "Rusticus res politicas animadvertens. The new poor laws." Elsewhere the StE spelling is used, apart from three occurrences of awver in "The feair market maid." In the word's only occurrence in rhyme, in the eclogue "Come and zee us in the Zummer" ("Well, aye, when the mowen is over, / An' ee-grass do whiten wi' clover, / A man's a-tired out,", the rhyme with clover suggests that proto-RP /o:/ was acceptable in the Blackmore Vale; but the complete consistency of the spelling auver in 1844 shows that the preferred pronunciation was / $\mathrm{a} /$.

7.14.11 For drove, grove, and rove see the discussion in 7.5.3 above.

7.14.12 For more, which is amongst the words listed in $\$ 27$ of the Diss. quoted at the head of this section, see 7.23.1.

7.14.13 Although sloth has diphthongal /ov/ in RP, the rhyme with swath in "Eclogue:- -The best man in the vield" ("Why when bist teddèn grass, ya liazy sloth, / Zomebody is a-fuoss'd to tiake thy zwath / An' ted a hafe woy back to help thee out") shows that the pronunciation for Barnes was with short $o, / \sin \theta /$.

\{7.14.14 Since don't is always thus spelled (with or without the apostrophe, but with no sign of diphthongization), I transcribe it throughout as /do:nt/. Won't, in contrast, is frequently spelled woon't; I take it that the pronunciation is $/ \mathrm{wu}(:) \mathrm{nt} /$. . 


\subsection{The GoOsE set}

The GOOSE set (Wells, 2.2.15) contains words with a stressed syllable that has the vowel / $\mathrm{u}$ / in RP and / $\mathrm{u} /$ in GenAm. The StE spellings of words in this set include oo (hoop, tooth), final o (who), final oe (shoe), $u+C+e$ (rude, tune), $u+C+V($ duty), eau $+C+V$ (beanty), ue (due, blue), en (feud), ew (few, new), iew (view), ui (fruit), ou (you, group), ough (through), etc.

This set offers few problems. There is no reason to suppose that most words with /u:/ in RP did not have it also in the Blackmore Vale.

7.15.1 There are many rhymes in Barnes's poems between words with /u:/ and words such as dew, few, new, etc. that have /ju:/ in RP. This might perhaps be taken to imply that "yod dropping," as Wells calls it (pp. 147-48) was a feature in the Blackmore Vale (i.e. loss of $/ \mathrm{j} /$, so that new is pronounced /nu:/, as in GenAm, as opposed to /nju:/, as in RP). But rhymes between /ui/ and /ju:/ are common in StE, as in moon / tune in Wordsworth's "The world is too much with us" (5-8), gloom / perfume in Tennyson's "In memoriam" (95.53-56), or fool/ mule in Robert Browning's "My last duchess" (27-28). In the absence of concrete evidence of yod dropping, therefore, I have assumed that words with /ju:/ in RP have it also in Barnes's poems.

7.15.2 Tune is always spelled tuèn, in both 1844 and later editions. It occurs in rhyme once only, rhyming not with the sound /un/ but with a-doèn (/ədu:ən/) in "Gammony Gaÿ." The only other occurrence of the combination ue that I am aware of in Barnes's poems is in the internal rhyme "Though a-ruèn time's undoèn" in "Tweil" (where a-ruèn = 'rueing'). The rhymes confirm what the spelling suggests, i.e. that tuen is disyllabic. Assuming that the yod is retained, the pronunciation will be / tjuiən/.

7.15.3 In a few words that have / $\mathrm{u}$ / in RP there are other vowels in Barnes's poems: $/ \Lambda /$ in roof (see 7.5.2), prove and move (see 7.5.3); $/ \mathrm{U}$ in moot 'treestump', food and mood (see 7.6.2); /v/ or /u:/ in shoot (see 7.6.3). 
7.15.4 A few words with /ov/ in RP have /u:/ in Barnes's poems: gold and golden (see 7.14.5); ago, go, no ('not any'), so ('and so, therefore'), sloe, and toe (see 7.14.6).

7.15.5 The spellings $y a$ and $d a$ are found frequently in 1844 for you and $d o$ (replaced by the StE spelling in later editions). I take it that ya and da represent the unstressed forms $/ \mathrm{jo} /$ and $/ \mathrm{do} /$.

7.15.6 I have assumed that to may be /tu:/, /tu/, or / to/, depending on stress, as in RP.

\subsection{The PRICE set}

The PRICE set (Wells, 2.2.16) contains words with a stressed syllable that has "long $i$," the diphthong /aI/, in both RP and GenAm. The StE spellings of words in this set include $I$ (the pronoun), $i+C+e$ (bide, ripe), $i+C+C$ (find, child), ie (die), uy, y, ye, and eye (buy, try, dye, eye), igh and eigh (bigh, height), etc.

7.16.1 Barnes's lack of comment on this diphthong suggests that the Blackmore Vale pronunciation would have been the same as that in proto$\mathrm{RP}$, namely $/ \Lambda \mathrm{I} /$, with a more central starting point than the /aI/ of presentday RP (see MacMahon, 5.8.15). In the SW the starting point tends to be more central still, though hard to pin down; the weight of evidence suggests, however, that in Dorset at least the starting point is and was the thoroughly central /o/, producing a diphthong /or/ (as in eMnE) that makes bye and buy sound very similar to boy (see 7.17.1). In accordance with observations on the likely length of the first element by the commentators closest to Barnes's own time, I transcribe the PRICE diphthong as /a:I/.

7.16.2 In words ending in -ire (fire, tire, squire, etc.) the diphthong becomes a triphthong by the addition of schwa as an off-glide, and the $r$ is audible (see 8.8.1), giving the combination the sound / $:$ iər/. Thus fire, with voiced initial $f$ - (see 8.3.1) and audible $r$ is in Barnes's poems /və:ır/. As in StE, words in this subset may be treated as either one syllable or two (see the note in OED s.v. fire, $n$.), a freedom that Barnes uses in accordance with the demands of his metre: "The vier at the upper door" in "Shodon Fiair: The vust piart" (1844) is plainly a disyllabic fire, whereas that in the refrain of "The settle 
and the girt wood vire" must be monosyllabic unless the line is hypermetric. It does not follow, however, that Barnes uses the form vire for a monosyllable and vier for a disyllable, helpful though such a convention would be: in both 1844 and later editions he uses vire in the title of "The settle and the girt wood vire" but vier in the refrain that repeats the wording of the title.

7.16.3 From both its spelling and its pronunciation in StE, spire belongs with the subset in the preceding paragraph. But Barnes's spelling is always speer (in both 1844 and later editions) and his rhymes show that for him it is a member of the NEAR set (see 7.19.2), retaining (or reverting to) the diphthong $/ \mathrm{i} / /+\mathrm{r} /$, which is closer to the monophthongal $/ \mathrm{i}: /+/ \mathrm{r} /$ from which its vowel descends.

7.16.4 Barnes spells cbild both child and chile and rhymes it with both -ild and -ile (for the rhyme with spoiled see 7.17.1). Both rhymes and spelling show that for him the vowel was /a:I/, as in 7.16.1.

7.16.5 In a number of words with / aI/ in RP Barnes's spelling and rhymes show that the diphthong is replaced by /I/. Notable amongst these words are climb, usually spelled clim or clim' and always rhymed with words in -im; also like (almost always spelled lik' in 1844 when it occurs as an adverb or in the past tense of the verb) and strike (usually strik or strick), both rhymed with words in -ick. Barnes appears to make a clear distinction between lik' (adverb and past tense) and like (infinitive, always spelled like in 1844, implying the usual diphthong, / o:I/). In view of Barnes's clear preference in his poems I transcribe all these words (except like, infinitive) with /I/. (For the past tense and past participle of climb see 7.16.10 below.)

7.16.6 Fly and flies (n. and v.) are in Barnes's dialect poems always vlee and vlees, i.e. /vli:/ and/vli:z/. The vowel probably results from the longstanding confusion in English between the verbs fly and flee and the nouns fly and flea (see the comments in OED, svv. flee and flea). For the voiced initial consonant see 8.3.1.

7.16.7 For /i:/ in chime and sbine see 7.10.2.

7.16.8 For /e:/ in drive see 7.10.6. 
7.16.9 I have assumed that by (normally /bə:I/) has also an unstressed form $(/ \mathrm{bI} /)$, as in StE. Where readers might opt for either a stressed or an unstressed form, I transcribe by as $/ \mathrm{b}(\partial \mathrm{a}) \mathrm{I} /$.

7.16.10 All tenses of the verb climb belong in the PRICE set in StE, including the past tense and past participle, climbed. In OE, however, climb was a strong verb, belonging to the same class as ring and sing, with the vowel sequence $i$ (present), $a$ (past singular), $u$ (past participle), these vowels all being short, as is still the case with sing, sang, sung. We have already seen that the $i$ in $\operatorname{clim}(b)$ remained short for Barnes (7.16.5), and this applies equally to weak forms of the past tense and past participle, whether the $b$ is dropped (as in the 1844 version of "The girt woak tree that's in the dell" - "Var in thik tree, when I wer young / I have a-clim'd, an' I've a-zwung') or whether it is retained (as in the later versions' “a-climb'd”). But Barnes's usual preference is for the strong forms that survived in the Blackmore Vale: past tense clomb and past participle a-clum ("The wold waggon," 1844), a-clom ("The wold waggon," later editions), or a-clomb ("When we wer young together"). The rhyme with a-come in "When we wer young together" and the 1844 spelling, -clum, show that the vowel in the past participle must have been $/ \Lambda /$. The rhymes with come, home (see 7.5.2, 7.14.3) and swum suggest the same for the past tense (given as clumb in the 1844 Glossary), even though it is spelled clomb in the poems, both in rhyme and outside it. I transcribe the strong forms of both the past tense and past participle of climb, accordingly, as $/ \mathrm{kl} \Lambda \mathrm{m} /$.

7.16.11 Since the vowel in grist is short in RP, the apparent rhyme between boist and grist in the opening lines of the last stanza of "Naïghbour plaÿmeätes" looks odd at first sight: “An' still the pulley rwope do heist / The wheat vrom red-wheeled waggon beds. / An' ho'ses there wi' lwoads of grist, / Do stand an' toss their heavy heads". OED notes that the vowel in grist was long in $\mathrm{OE}$, but was shortened in $\mathrm{ME}$ (as in fist from OE fj́st). But some of the 16th- and 17th-century spellings of grist recorded there (greest, greist, and griest) suggest the survival of $\mathrm{ME} i$ into the MnE period. Since there is no pattern of half-rhyme in "Naighbour plaÿmeätes," it is reasonable to assume a full rhyme between heist ('hoist') and grist, with the $\bar{i}$ of the latter first diphthongized and having then undergone the CHOICE-PRICE merger 
(see 7.16.1 above and 7.17.1 below). I take it, therefore, that grist is to be pronounced /grərist/ rather than /grist/.

7.16.12 The verb to leine appears twice in Barnes's poems, on both occasions rhyming with behine ('behind'): in the second stanza of "The welshnut tree" ("A-leävèn fāther indoors, a-leinèn / In his girt chair, in his èasy shoes, / Ar in the settle so high behine en") and the second stanza of "The huomestead a-vell into han" " "An' in the archet out behine, / The apple-trees in row, John, / Did swây wi' upright stems, ar leine / Wi' heads a-noddèn low, John," 1844 and 1847). The sense is evidently "to lean," but the rhyme with bebine requires the vowel of line rather than that of lean. Barnes's 1886 Glossary records "LINE. To lean" with no etymology; the Glossary in 1847 is more helpful, both showing the length of the vowel ("Line") and offering an etymology ("A-S. hlynian," a variant, I take it, of bleonian, from which StE lean is derived). As with most other words in the PRICE set the vowel will be /ə:I/, hence / bə:In/.

\subsection{The CHOICE set}

The CHOICE set contains words with a stressed syllable that has the diphthong /or/ in both RP and GenAm, almost all "ultimately loan words, mainly from Old French" (Wells, 2.2.17). The StE spellings of words in this set are oi (noise, voice, coin, etc.) and oy (boy, joy, etc.).

7.17.1 As Wells points out, “The CHOICE vowel seems to have merged with PRICE in the popular speech of parts of the south of England.... The same merger can be found in Newfoundland, the West Indies and Ireland" (3.1.11); or, again, "Some conservative rural accents reflect a merger or partial merger of the two diphthongs"(2.2.17). Such was evidently the case for Barnes, who draws attention to this feature in $\$ 26$ of the Diss., who frequently rhymes words from one set with words from the other, and whose early spellings (e.g. spwile, twile, pwison) point up the similarity. It follows that the pronunciation of the CHOICE diphthong in Barnes's dialect will normally be the same as that of the PRICE diphthong, i.e. /orI/ (see 7.16.1). (For the $w$-glide introducing the diphthong see 8.16.3.) 
7.17.2 Noise, quoits, rejoice, and voice are always spelled with $\hat{a} i$ (1844) or ä̈ (later editions); evidently they have the same diphthong as the subset maid, paid, vein, etc., that is, /æI/ (see 7.11.6).

7.17.3 The spelling of joy and its derivatives varies between oy, as in StE, and ay or äy in Barnes's poems, and it is rhymed both with boy (see 7.17.4) and with words from the May, hay subset (see 7.11.6), showing that the diphthong varies between /ə:I/ and /æI/.

7.17.4 Unlike Jennings, who spells boys with ay (in bways, rh. ways), Barnes always uses oy for the diphthong in boy and its derivatives. When boy rhymes in Barnes's poems with words that are spelled with ay in StE, the spelling of the latter is always changed to conform with the $y$ in boy, not vice versa. The logical conclusion is that the diphthong in boy is stable (pronounced/ail/, as described in 7.17.1), whereas that of the rhyme words in ay, $\hat{a} y$ or äj varies. (For the intrusive /w/ in bwoy see 8.16.3.)

\subsection{The MOUTH set}

The MOUTH set (Wells, 2.2.18) contains words with a stressed syllable that has the diphthong /av/ in both RP and GenAm. The StE spellings of words in this set are ou (bouse, out, bough, hour, etc.) and ow (now, down, flower, etc.).

7.18.1 The current pronunciation of this diphthong, /av/, "appears to have been a twentieth-century development" (MacMahon, 5.8.18, p. 467). There is abundant evidence that in Dorset in the 19th century the diphthong was /a:u/, very similar to that in current RP know.

7.18.2 In the sequences our and ower (as in hour and flower) the diphthong becomes a triphthong, as in StE. The pronunciation in Barnes's poems will accordingly be /aruər/, which, like fire etc. (see 7.16.2), may be treated as one syllable or two as the metre demands.

7.18.3 As pointed out in 7.13.8c, Barnes's comments on fought (Diss., \$24) and his rhyming of it with about, out, and stout (see Key-Rhymes 111) show that in his poems it has the diphthong / a:u/. 
7.18.4 A few words with the vowel $/ \Lambda /$ in StE have instead the /oru/ diphthong of words in the MOUTH set in Barnes's poems, either always, as in the case of rut (n.), and strut ( $v$., and in the adv. a-strut 'sticking out') (see 7.5.4), or usually, as in the case of dust and crust (see 7.5.5).

\subsection{The NEAR set}

The NEAR set (Wells, 2.2.19) contains words with a stressed syllable that has the diphthong / ro/ in RP (with or without a following /r/) and / rr/ in GenAm. The StE spellings of words in this set include eer (beer, peer, etc.), ere (here, mere, etc.), ier (bier, pier, etc.), eir (weir, weird, etc.), and ear (fear, year, etc.), but spellings are not a reliable guide: here belongs with NEAR, but there and where with SQUARE; and the tears in one's eyes are with NEAR, but the tears in one's clothes are with SQUARE.

It is not entirely clear at what point the vowels in the NEAR and SQUARE sets developed into diphthongs under the influence of the following $/ r$, either in proto-RP or in the SW. In the absence of conclusive evidence to the contrary, I treat all words in these sets in Barnes's Blackmore Vale poems as diphthongs (except where noted below), but (in contrast to RP) without loss of the following / $\mathrm{r} /$ (see 8.8.1).

7.19.1 There is no evidence to suggest that the majority of words in the NEAR set do not have a diphthong very similar to RP / Iə/ in Barnes's poems. In Barnes's contribution to EEP Ellis's transcription shows the same diphthong, with a slightly higher starting point (/ior/), in here, hear, and near (cwl 365). I follow Barnes's contribution to EEP in using /ior/, except where noted below.

7.19.2 As noted earlier, rhyme evidence shows that spire has /irr/ in Barnes's poems, as opposed to RP / arə/ (see 7.16.3).

7.19.3 In popular caricatures of west-country accents ear, hear, here, and year are homophones, all with the vowel sequence of the NURSE set (7.9 above), and all with initial $/ \mathrm{j}$ / (for which see 8.5 .5 below), thus $/ \mathrm{jar} /$. The spelling yers for ears in the 1844 version of "Uncle an' ānt" and the rhyming of year with stir and Hazelbur (/ha:zəlbə:r/, still the local name for Hazelbury Bryan) 
in "Bob the fiddler" show Barnes's familiarity with pronunciations of this type; but other evidence from rhyme suggests the coexistence in his dialect of pronunciations with /irr/.

7.19.4 Whereas hear belongs in the NEAR set in StE, its past participle, heard, belongs in the NURSE set. Rhyme evidence shows that in Barnes's poems (in which it is usually, but not always, spelled heärd) it may have /ərr/, /jərr/ or /ior/ (see 7.9.6).

7.19.5 There is some crossing over between the NEAR and SQUARE sets in the SW, as in other regional dialects of English (see Wells, 2.2.20, p. 157). In Barnes's case rhyme evidence shows that rear and weir have crossed over to the SQUARE set, with / عər/ in place of /irr/; and although queer does not appear in rhyme in his dialect poems, Ellis's transcription in clause 5 of Barnes's cs suggests that it, too, has / عər/. All three of Barnes's crossovers from NEAR to SQUARE are supported by other witnesses for the SW.

\subsection{The SQUARE set}

The SQUARE set (Wells, 2.2.20) contains words with a stressed syllable that has the diphthong / $\varepsilon$ / / in RP (with or without a following /r/) and / $\mathrm{r} /$ or $/ æ r /$ in GenAm. The StE spellings of words in this set include air (fair, hair, etc.), are (bare, care, etc.), ear (bear, wear, etc.), eir (heir, their, etc.), ere (there, where, etc.), and $a r+V$ (Mary, various, etc.); some words with these spellings belong, however, with the NEAR set (see 7.19). On the question of diphthongs versus pure vowels see the introductory paragraphs to the NEAR set.

7.20.1 Most words with / $\varepsilon$ / in RP have / $\varepsilon$ :ər/ or / $\varepsilon ə r /$ in both Elworthy's records for West Somerset (DWS, \9) and Widén’s for Hilton (SDD, \$29.3), i.e. the same diphthong as in RP (with optional lengthening of the first element) but without loss of the following $/ \mathrm{r} /$ (see 8.8.1). I assume that the same holds for Barnes's poems; where there is no conflicting evidence, accordingly, I transcribe the sound in SQUARE words as / عər/.

7.20.2 Barnes's habitual spelling of words in -air and -are (fair, pair, mare, share, etc., the FAIR and MARE subsets, as they might be called) is with -iair 
and -iare (1844) or -eäir and -eäre (later editions), thus fiair or fiare, piair, miare, shiare (1844), feäir, peäir, meäre, sheäre (later editions). These spellings suggest the introduction of an $i$-glide, with possible reduction of the following diphthong to $/ \partial /$, resulting in the crossover of words in these subsets to the NEAR set, with the diphthong $/ \mathrm{i} /+/ \mathrm{r} /$. But in Barnes's poems words from these subsets are consistently rhymed with SQUARE words, never with NEAR words, showing that the introductory $i$-glide in the FAIR and MARE subsets does not result in weakening of the following diphthong to $/ \mathrm{\partial} /$, but leads instead to the creation of a triphthong $+/ \mathrm{r} /$, i.e. $/ \mathrm{j}$ kər/.

7.20.3 Barnes's habitual spelling of where in 1844 is wher, with only occasional instances of StE where; that of there (more often than not) and their (almost always) is ther. (In almost every instance these spellings are replaced by the StE spellings in 1879.) The spellings in -er suggest pronunciation with /or/ rather than / عər/, and there is some support for this in the rhyme togither/ ther (in "Eclogue:- -Two farms in oone"). On the other hand, Barnes's normal rhymes for where and there are orthodox rhymes with other words from the SQUARE set. It would appear that for their, where, and there pronunciations with /ər/ and with / عər/ were both acceptable in his dialect.

7.20.4 Whereas scarce belongs in the SQUARE set in RP, the /r/ is lost in Barnes's poems through the influence of the following / s/ (see 8.8.5, and cf. 7.9.5). Introduction of the $i$-glide discussed in 7.20 .2 and loss of $/ \mathrm{r} /$ before /s/ give rise to Barnes's spellings skia'ce (1844) and skeäce (later editions); and it is clear both from these spellings and from the rhyme with less in "Eclogue:-Two farms in oone" ("Tha hadden need miake poor men's liabour less, / Var work a'ready is uncommon skia'ce") that in Barnes's dialect scarce is a member of the FACE set, with the diphthong /je/ (see 7.11.1).

7.20.5 Barnes's normal spellings of the word air itself are air (1844) and aïr (later editions), suggesting a distinction in sound from words in the FAIR subset. Though the word occurs frequently in Barnes's poems, to the best of my knowledge it occurs only twice in rhyme, both times rhyming with prayer (spelled praï'r, in "The leädy's tower" and "The echo"). It is reasonable to 
deduce from this evidence that the vowel in air is /æI/ (see 7.11.6) with following $/ \mathrm{r} /$, giving the complete word the sound /ærr/. Occasional instances of the spelling aier suggest, however, that pronunciation with a triphthong, /æır/, is also possible (cf. fire, 7.16.2). \{An alternative explanation might be that air is always a triphthong, irrespective of how it is spelled, and that, like other triphthongs such as ire and our, it may be pronounced as either one syllable or two as the rhythm requires.\}

7.20.6 The spelling -âir and/or -aïr also occurs occasionally in fair, chair and stair. Since, however, the forms chair (in "The vierzide chairs") and feair (in "The surprise") both rhyme with there, we may reasonably take it that the spellings with -air and -aïr are oversights, and that these words are all pronounced with final / $\varepsilon ə r /$.

7.20.7 The rhyme beware/ var in "Havèn oon's fortun a-tuold" ("An' then she tuold me to bewar/O' what the letter $M$ stood var.... An' Poll too wer a-bid bewar / O' what the letter F stood var') suggests that the stressed syllable of beware is not /weər/ but /war/, as in the START set. (For var see further 7.22.3.)

\subsection{The START set}

The START set (Wells, 2.2.21) contains words with a stressed syllable spelled with ar (or occasionally er or ear) that has the sound /a: in RP in final position or followed by a consonant (/a:r/ when final $-r$ is followed by a vowel) and /ar/ in GenAm: far, farm, cart, heart, hearth, sergeant, etc.

7.21.1 There is no evidence in Barnes's poems to suggest that the vowel in the majority of the words in the START set differs from that in the BATH set (with a following $/ \mathrm{r} /$ ). Accordingly my normal transcription for the ar sequence in this set is /arr/ (see 7.7.1 and 8.8.1).

7.21.2 Barnes's spelling of the words card (but not cart), garden, and part (iar in 1844, eär in later editions, thus g(b)iarden, kiard, piart, and geärden, ceärd, peärt), shows that they form a subset in which an introductory $i$-glide gives rise to the sequence /ja:r/. The dialect word spiarde ('spade', replaced by speäde in 
later editions) appears to belong to the same set. Rhyme confirms that the stress is on the second element. It may seem odd that Barnes distinguishes the opening sequence in card (/kjaird/ with an introductory $i$-glide) from that in cart (/ka:rt/ with no glide), but Elworthy notes the same distinction in West Somerset (DWS, \$2). The records in SED suggest, however, that the introductory $i$-glide has died out in all words in the SW by the mid 20th century.

7.21.3 Garden has (apparently) an alternative pronunciation, /giordən/, with the /irr/ sequence of the NEAR set, beside /gja:rdən/ (as in 7.21.2). This assumes that heärd en / giarden in "Faether come huome" (1844; later editions geärden) is a true rhyme ("The pig got out/This marnen; an' avore we zeed ar heärd en, /'E runned about an' got out into giarden, / An' routed up the groun' zoo wi' his snout"), and that beärd has here its NEAR-set pronunciation (see 7.9.6).

7.21.4 Hearth belongs with the START set in StE (and indeed in Barnes's contribution to EEP for Winterborne Came, cwl 405), but both spelling (beth or he'th) and rhyme show that in Barnes's poems it is $/ \mathrm{h} \varepsilon \theta /$, not /ha:r $\theta /$, making it a member of the EARTH-BIRTH-MIRTH subset (see 7.9.5).

7.21.5 Several subsets that do not belong with the START set in StE have the sequence /arr/ in Barnes's poems. These sets include the following:

a) words spelled with or or ar pronounced /o: in RP (corn, storm, warm, etc.; see 7.22.1-2);

b) some words spelled with er or ear pronounced /ə:/ in RP (serve, learn, herb, etc.; see 7.9.2);

c) the verb carry and its derived forms (see 7.3.3).

7.21.6 Barnes's spelling of arm in 1844 (yarm, replaced by eärm in later editions) shows that it is preceded by an introductory $i$-glide, resulting in the sequence /ja:r/ (cf. words beginning with earn in StE; see 7.9.3). 


\subsection{The NORTH set}

The NORTH set (Wells, 2.2.22) contains words with a stressed syllable spelled with or or ar that has the sound /o: / in RP in final position or followed by a consonant (/orr/ when final $-r$ is followed by a vowel) and / or/ in GenAm, "or rather in that variety of GenAm that retains the opposition between /or/ and /or/" (p. 159): or, for, corn, horse, storm, war, warm, warp, etc.

7.22.1 As Barnes himself points out, “The second long [back] sound of $o$ in such words as corn, for, horn, morning, storm, becomes the first long [back] one, a, making carn, var, harn, marnen, starm" (Diss., \$25). The persistence of this feature up to the present time is shown by Wells's comment, "There is a large patch of Wessex where (in old-fashioned rural dialect, at least) we find the vowels of NORTH and START merged" (4.3.7, p. 347). We may accordingly expect that all words in the NORTH set (apart from those noted in 7.22.4) will have the START sequence, /arr/, in Barnes's poems. This expectation is confirmed both by his rhymes and by the spelling of 1844, in which the following words (and their derivatives) are all spelled with ar for StE or: corduroy, cork, corn, corner, for, forfeit, forget, forgive, fork, forlorn, former, forsake, horn, lord, morn(ing), mortal, mortar, nor, northern, or, orchard, scorn, short, snort, sort, storm, story, thorn (1844: cardrây, cark, carn, carner, var, farfeit, vargit, vargi'e, fark, varlarn, farmer, varsiake, harn, lard, marn(en), martal, martar, nar, narthern, ar, archet, scarn, shart, snart, sart, starm, starry, tharn). Accordingly I transcribe the or sequence in all such words as /a:r/.

\{The rhyming of story (from the list above) with var ye ("A bit o' sly coortèn," "The times") and barry ("borrow," "The witch") confirm its pronunciation in those poems with $/ \mathrm{a}(\mathrm{i}) \mathrm{r} /$, but Wells classifies it as a FORCE word (see 7.23.1); and this is confirmed in "Bob the fiddler" both by the spelling story (even in 1844) and the rhyme with avore ye / glory. Assuming that this is a true rhyme, story can have either NORTH or FORCE pronunciation in the dialect; glory has the latter (/uər/).\}

7.22.2 Though they are not specifically mentioned in Barnes's comment in \$25 of the Diss., words with ar pronounced / $\mathrm{o}(\mathrm{r}) /$ in RP likewise have the sequence /arr/ in his poems, as shown by rhymes such as warm / harm and swarm/farm. 
7.22.3 When particles such as for, or, and nor are stressed, they will have the expected sequence, /arr/, as implied by the rhyme bewar / var in "Havèn oon's fortun a-tuold". When, however, they are only partly stressed or unstressed (as is frequently the case), it seems probable that the sequence /ar/ is reduced to /ar/ or /or/, as in Barnes's cs for EEP, clauses 10 and 12 (for), 7, 10, and 14 (or), and 1 (nor). The degree of stress in any particular case is, of course, a matter for the reader to decide. Barnes's own varied practice confirms the variability in pronunciation; but his complete abandonment of the ar spellings from the 1859 collection onwards, in order to give "the lettered Dialect more of the book-form of the national speech" (Preface, p. [iii]), can have no bearing on the pronunciation.

7.22.4 Words with the sequence ors or orth in StE pronounced /o:s/, / $: 0 /$ in $\mathrm{RP}$ and /ors/, /or / in GenAm are an exception to the general rule set out in 7.22.1. Loss of $/ \mathrm{r} /$ before $/ \mathrm{s} /$ and $/ \theta /$ (see Diss., \$35) has led to retention of short $o$ in the sequences /ps/ and / $\mathrm{p} \theta /$. This is evident from Barnes's spellings: hoss or ho'se for horse (passim), and no'th for north (in "The shep'erd bwoy," though North is retained in proper names; and contrast narthern or northern with voiced /ð/ preceded by /arr/ in "The blackbird" and other poems). The pronunciation with / ps/ is confirmed by rhymes for horse, always with words ending in -oss. As with horse so with Dorset: in spite of the popular perception that to its inhabitants the county is /da:rzət/, Barnes in his poems always uses the spelling Do'set. The inescapable conclusion is that for Barnes the county was /dpsat/.

7.22.5 Whereas quarrel, sorry, and other words with -arr-or -orr- belong in the CLOTH set in RP and GenAm, rhymes show that in Barnes's poems they behave like words in the NORTH set, possibly with /ar/ or /ar/ rather than /arr/ for /o(:)r/. SED shows that in four of its five Dorset locations in the 1960s the pronunciation with short /a/ was still the norm in quarry (IV.4.6). 


\subsection{The FORCE set}

The FORCE set (Wells, 2.2.23) contains words with a stressed syllable spelled with or $+C$, ore, oar, oor, or our that has the sound /o: in RP (/orr/ when followed by a vowel) and /or/ in GenAm, "or rather in that variety of GenAm that retains the opposition between /or/ and /or/" (p. 160): ford, porch; before, bore, more; boar, hoarse; door, floor; four, mourn, course, source, etc.

7.23.1 Present-day RP speakers who read Barnes's Diss. are likely to be puzzled by finding more listed (in \$27) as having the same vowel as bold, oak, rope, coat, etc., since those words belong in the present-day GOAT set whereas more belongs in the FORCE set. Evidently more and other words in the current FORCE set preserved earlier close $\bar{o}$ (/o:/) in proto-RP (see 7.14 above), and this is reflected in Ellis's transcriptions of some of these words in Barnes's contribution to EEP, e.g. avore, bored, and board. Nevertheless (as discussed in 7.14.1-3) the more usual transcription is /uə/ (/uər/ when the vowel is followed by $r$, as in the present instance), and this is shown in Ellis's transcriptions of afford, more, sore, door, and swore, all of which have /uər/. Since, moreover, the distinction Barnes makes between the sound in avore and that in door in his report on Winterborne Came for EEP is not reflected in his poems, where words in -ore are rhymed frequently with words in -oor, I transcribe all words in the FORCE set with /uər/, except where indicated below.

7.23.2 The rhyme door / four in "Come an' meet me, wi' the childern, on the road" ("Zoo when clock-bells do ring vour, / Let em warn ye out o' door") is unsurprising to present-day readers, since these words rhyme in StE). But Barnes's preferred spelling of four is vower or vow'r rather than vour (which it has only rarely), and the spellings with ow suggest that four normally belongs in the MOUTH set in his dialect, with the pronunciation /ouør/, like flower, bour, etc. (see 7.18.2). This accords with Barnes's report for Winterborne Came in EEP, where four is transcribed as /vəuror/ (cwl 420). It is not clear whether four has an alternative pronunciation, /vuər/, or door an alternative, /dəruər/, either of which would allow an exact rhyme, or whether the rhyme is in this instance only approximate. 
7.23.3 The rhyming of hour with floor (in "Eclogue:-Viairies") and with core (in "The geäte a-vallen to") looks more unusual to present-day readers, but in Barnes's dialect it is similar to that of door with four: a FORCE word (/vluər/, /kuər/) is rhymed with a MOUTH word (/əruər/), and it is not clear whether alternative pronunciations allow an exact rhyme or whether the rhyme is approximate. \{Since floor is invariably spelled with ou in 1844 (whether as vlour or vlou'r), its pronunciation with / aruər/ seems probable.\}

7.23.4 In the rhyme avore / lower in "Eclogue:-The times" (if the Corn Laws were abolished, farmers would pay less rent, and prices "wood be low'r/Var what ther land woo'd yield, an' zoo ther hands / Wou'd be jist wher tha wer avore") it is reasonable to assume that the stressed vowel in lower has its expected pronunciation, /o:/ (see 7.14.8). In normal circumstances the addition of the comparative suffix / or/ would make lower disyllabic; but both metre and the spelling low'r (in both 1844 and later editions) suggest that the word is here treated as monosyllabic, hence /lorr/ rather than /lo:ər/. This would permit an exact rhyme with /ovorr/, as in Barnes's report on Winterborne Came for EEP (see 7.23.1 above).

7.23.5 Whereas morning and mourning have become homophones in RP, they remain distinct in Barnes's poems, the former (/marnən/) belonging to the NORTH set (see 7.22.1), as in the "marnen zun" of "The Spring" (1844), the latter (/muərnən/) belonging to the FORCE set, as in the "moornen" (1844) or "murnèn" (later editions) kerchief worn by Jenny in "The ruose that deck'd her breast" when her Robert died. But rhymes with burn, kern, and turn (supported by the spelling, usually murn) show clearly that Barnes's preferred pronunciation for mourn is /morn/, making it in his dialect a member of the NURSE set.

7.23.6 Loss of $/ \mathrm{r} /$ before $/ \mathrm{s} /$ affects words with the sequence oars or ours just as it does words with ors (see 7.22.4), but with differing results.

a) In hoarse, which occurs to the best of my knowledge only in the "huosse" (1844) or "whoa'se" (later editions) cuckoo of "I got two vields," the 1844 spelling suggests diphthongization of long 0 , which I transcribe as /uə/ (see 7.14.3), giving / huəs/. 
b) In course, both in of course ("in coose" or "in coo'se" in Barnes's poems) and in the verb to course ("to chase'), both spelling and rhyme (e.g. with woose 'worse' in "A witch") point to the sound / ku:s/.

\subsection{The CURE set}

The CURE set (Wells, 2.2.24) contains words with "the stressed vowel /uə/ in conservative RP" ("now increasingly being replaced by /o:/") "and the sequence /ur/ in GenAm" (p. 162). This includes some words with the spelling oor (e.g. moor, poor), some with our (e.g. tour, your), some with ure, $u r+V$, or ury (e.g. pure, sure, curious, rural, fury), and some with eur (e.g. Europe).

7.24.1 It is evident from rhyme that Barnes does not distinguish in his poems between the vowel of the FORCE set and that of the CURE set: more (from the former) rhymes frequently with poor and sure (both from the latter); sure rhymes with more (from the former), poor (from the latter), and $d o$ er (a near homophone of dour, from the latter). The length of the first element of the sequence / uer/ appears to be variable, tending towards long in CURE words and short in FORCE words. The long first element would accord with the transcription/Suiər/ for sure in Barnes's contribution to EEP (cs clause 4), and would make an exact rhyme with do er (/du: or/); but since the difference is insufficient to prevent the rhyme with more (/muər/), it makes sense to use for CURE words the transcription $/ \mathrm{u}(:)$ ər/.

7.24.2 The pronoun your is frequently unstressed, and this is sometimes shown in 1844 in the spellings yer and yar (all replaced by StE your in later editions). Whenever the word is unstressed, irrespective of its spelling, I take it that the pronunciation is /jər/, as still frequently heard today. 


\section{CONSONANTS}

Consonant sounds are generally less troublesome than vowel sounds; the comments Barnes makes on them in his grammars are for the most part clear and precise; and his spelling (in both early and late editions of his poems) is usually a helpful guide to their pronunciation. Consonant sounds that are not discussed in this section may be assumed to have the same pronunciation as in RP; differences from RP in single consonants and consonant clusters in Barnes's poems are listed below in alphabetical order of the key consonant(s) concerned.

\section{$8.1 C$}

As shown by Barnes's spelling of cuckoo (invariably gookoo, in both early and late editions) $/ \mathrm{k} /$ is occasionally voiced to $/ \mathrm{g} /$. For the reverse process see 8.4.2 below.

\section{$8.2 D$}

8.2.1 "An open palate letter is sometimes substituted for a close one, $r$ for $d$ ... as parrick, a paddock" (Diss., \$39); in phonemic terms /r/ replaces /d/ in some words, as shown by Barnes's spelling, parrick (early) or parrock (later editions).

8.2.2 ' $d$, after $n$, as in an', and; boun', bound; groun', ground; roun', round; soun', sound; is commonly thrown out, as it is after l: as in veel, for field" (Diss., \$30). This loss of final /d/ in the consonant clusters /nd/ and / ld/ is reflected in frequent rhymes between words ending in -ound in StE and words ending in -own, and between field and words ending with the sound /irl/. But "commonly" does not mean 'always'; Barnes's more usual spellings are with -nd or - $l d$; and the rhymes round / crown'd ("The shepherd o' the farm") and field/ wheel'd ("Hallowed pleäces") show that retention of final /d/ is sometimes obligatory. My policy, accordingly, is to transcribe these two clusters outside rhyme as $/ \mathrm{n} /$ and $/ \mathrm{l} /$ when Barnes omits the final consonant, and as $/ \mathrm{n}(\mathrm{d}) /$ and $/ \mathrm{l}(\mathrm{d}) /$ when he retains it, showing that the final $/ \mathrm{d} /$ is optional; in rhyme I use $/ \mathrm{n} /, / \mathrm{nd} /, / 1 /$, or $/ \mathrm{ld} /$ as the rhyme requires. 
8.2.3 In a note added to $\$ 29$ in the 1847 Diss. (repeated in the 1863 Grammar, p. 16) Barnes points out the substitution of /ð/ for /d/ in ladder and bladder. This substitution is consistently shown in 1844 (e.g. in the "lather" that plays such an important part in "What Dick an' I done" and the "blathers" hanging round the walls in "The settle an' the girt wood vire"); but StE spelling is usually restored in later editions.

8.2.4 In 1844 both spelling (always archet) and rhyme (archet / sarch it, "The welshnut tree") show that the final consonant of orchard is not /d/ as in RP but voiceless $/ t /$. (For the pronunciation of the first syllable in orchard see 7.22.1.) In later editions the spelling is usually orcha'd (which is likely to mislead present-day readers into thinking the pronunciation is /ortfəd/, as in $\mathrm{RP}$ ); since, however, Barnes retains the rhyme with sarch it (in spite of respelling orchard as orcha't), we may reasonably assume that the pronunciation is still /a:rt〕t/.

\section{$8.3 \mathrm{~F}$}

8.3.1 The voicing of initial fricatives, in particular /f/ to $/ \mathrm{v} /$ and $/ \mathrm{s} /$ to $/ \mathrm{z} /$ (for which latter see 8.9.1), is one of the best-known features of SW dialects (see Wells, 4.3.6, p. 343); Wakelin, indeed, calls it (as far as the written record is concerned) "the SW feature par excellence" (I.4.2, p. 29). In Barnes's words, " $f$ of English words is commonly rejected for its smooth kinsletter $v$ before a vowel or liquid in the Dorset dialect, in which fast, fetch, feed, find, fire, for, foot, from, become vast, vetch, veed, vind, vire, var, voot, vrom"; but "some English words beginning with $\mathrm{f}$ before a consonant, as fling, friend, retain $f$ " (Diss., $\$ 31$; see $\$ 17$ for Barnes's explanation of the terms rough and smooth). Not all eligible words always have voiced $f$ (fan, not van; fall = 'autumn', as against vall, verb; farmer (1844) / former (later editions) = 'former'); but this will not cause difficulty since Barnes retains the spelling $v$ - for voiced $f$-in all editions of the poems. Other commentators have noted instances of loan words that are affected by voicing: Widén, for example, recorded /v/ in several loan words from French in the mid 20th century, including face, farm, feast, fine, and finish (SDD, \$74.1b); but Barnes spells all these words with $f$ and is remarkably consistent in showing that for him it is only in Germanic 
words that initial /f/ is voiced. He spells this out plainly in both the 1863 Grammar (p. 16) and the 1886 Glossary (p. 8): “... the Dorset does not hold $V$ for $F$ in words that are brought in from other and not Teutonic languages. We must say Factory, false, family, famine, figure, in Dorset, as well as in English."

8.3.2 "The preposition of loses its $f$ and becomes $o$ ' before a consonant" (Diss., §31). This self-explanatory comment is borne out many times in Barnes's poems, e.g. in the titles "A bit o' fun," "Keepèn up o' Chris'mas," "The music o' the dead," etc. I take it that the reduced (and unstressed) $O$ ' is merely a schwa in pronunciation and transcribe it as $/ \mathrm{\partial} /$.

8.3.3 The possessive combinations of en, of it, of us, of them are normally abbreviated to $o+$ the final consonant (o'n, o't, o's, o'm). Barnes's preferred spelling of these combinations in 1844 is with $\bar{o}^{-}\left(\bar{o}^{\prime} n, \vec{o}^{-} t, \bar{o}^{\prime} s, \bar{o}^{\prime} m\right)$, showing that the 0 is lengthened. I accordingly transcribe it as /o:/ in such combinations, even when (as usually in later editions) the length mark is omitted.

\section{$8.4 G$}

8.4.1 The occasional spelling ghi, as in gbiame, ghiarden, and ghirt, may appear at first sight to suggest aspiration after initial /g/; more probably, however, the $b$ is inserted between $g$ and $i$ (as in Italian) to show that the initial consonant is the stop $/ \mathrm{g} /$ as opposed to the fricative $/ \mathrm{d}_{3} /$.

8.4.2 Devoicing of $/ \mathrm{g} /$ occurs in some environments, as suggested by the spelling fakket for faggot in the 1844 and 1847 versions of "Guy Faux's night" and "What Dick an' I done" (respelled as in StE in later editions). For the reverse process see 8.1 above.

8.4.3 "The termination ing of verbal nouns such as singing and washing, as well as imperfect participles, is in Dorset en; as in a beäten, a beating; writen, writing" (Diss., $\$ 42)$. In the poems Barnes usually spells this -en ending -èn. For a discussion of the pronunciation see 7.1.5.

8.4.4 Present-day audio recordings show uncertainty amongst readers as to whether the initial $g$ in gilcup is hard $(/ \mathrm{g} /)$ or soft $\left(/ \mathrm{d}_{3} /\right)$. The etymological 
comment Barnes supplies in the 1886 Glossary shows that /g/ is correct: "GIL'CUP or Giltycup. Giltcup; the buttercup, (ranunculus bulbosus); so called from the gold-like gloss of its petals."

\section{$8.5 H$}

8.5.1 "In the working-class accents of most of England, H Dropping prevails. That is to say, the $[\mathrm{h}]$ of standard accents is absent: words such as bit, happy, hammer, hedge, begin with a vowel" (Wells, 3.4.1, p. 253). But Somerset and parts of Wiltshire and Dorset "are traditionally ' $/ \mathrm{h} /$-areas', i.e. areas where strong aspiration is retained, as distinct from most other dialect areas, where it is lost" (Wakelin I.4.2, p. 31). Since there is no mention of $\mathrm{H}$ Dropping in Barnes's grammars, and no sign of it in either his earlier or his later spelling system (except in the unstressed personal pronouns 'e, 'er, etc., where loss of initial $/ \mathrm{h} /$ is as common in StE as in any class or regional dialect), we may reasonably deduce that the Dorset represented in Barnes's poems is a traditional $/ \mathrm{h} /$-area, where the $/ \mathrm{h} /$ is retained in bit, happy, etc.

8.5.2 In contrast to the $\mathrm{H}$ Dropping that is common elsewhere, Barnes points out that initial $/ \mathrm{h} /$ from $\mathrm{OE}$ is often retained in his dialect in words that have lost it in StE, and introduced in others that did not have it in OE. In the 1886 Glossary he gives a list of some two dozen words beginning with $r$ - in which the initial consonant is "hard breathed" in Dorset, i.e. words which begin with the combination /hr/ rather than simply /r/ (pp. 9-10). After the list Barnes supplies a specimen sentence containing a whole series of aspirated rs: "He hrode by hroughest hroads, and hrugged hrocks where hrobbers hroamed." But there is no mention of aspirated initial $r$ in the Diss., and Barnes does not use the spelling $h r$-for initial $r$ - in any edition of his poems. Since it appears that aspirated initial $r$-was a feature of the dialect that Barnes chose not to portray in his poems, I do not use the combination $/ \mathrm{hr} /$ in my phonemic transcripts of the poems.

8.5.3 If there is aspiration in the dialect Barnes describes in sounds that are not aspirated in StE, it is reasonable to suppose that initial wh- (from OE $h w-)$ is aspirated in the dialect in words such as what, when, where, which, why, etc. that were formerly pronounced with / hw/ in RP, and are still so 
pronounced in Scotland, Ireland, and parts of the north of England. Barnes consistently spells such words with wh- in his poems; but it is not clear whether the spelling is merely conventional, or whether it confirms the pronunciation with $/ \mathrm{hw} /$. Barnes does not comment on $w h$ - in the Diss., but in the 1886 Glossary, immediately after his list of words with aspirated initial $r$, he writes: "So Dorset has kept the hard breathed W, in some words from which it is often dropped, as bwey, whey. hwarf, wharf. hwing, wing" (p. 10, my italics). Two things are of note here: the phrase "in some words," which makes it clear that aspiration is not present in all words with wh-; and the inclusion of wing, always spelled with $w$ - in the poems (as in "The blackbird," “The sky a-clearèn," etc.), never with $h w$ - or $w h$-, which suggests that (as with initial $r$-) Barnes did not wish to show this aspiration in his poems. The only safe transcription appears to be $/(\mathrm{h}) \mathrm{w} /$, showing that aspiration is possible but not obligatory.

8.5.4 Who and whole are of course excluded from the preceding discussion, since their pronunciation in $\mathrm{StE}$ is with $/ \mathrm{h} /$ as opposed to $/ \mathrm{hw} /$ or $/ \mathrm{w} /$. I transcribe both words with $/ \mathrm{h} /$ as in $\mathrm{StE}$.

8.5.5 A well-known feature of west-country dialects to this day is the substitution of $/ \mathrm{j} /$ for $/ \mathrm{h} /$ in hear (and its derivatives) and here, (as well as the introduction of initial $/ \mathrm{j} /$ in ear), making these words homophones of year. But Barnes makes no mention of this feature in his grammars; his cs for Winterborne Came in EEP has /h/ in here (clause 1) as well as in hear and heard (clauses 4 and 13); and in his poems he normally spells these words with $b$-, and ear as in StE. I transcribe here, hear, and heard, accordingly, with $/ \mathrm{h} /$, and ear with no initial $/ \mathrm{j} /$ (except in instances where Barnes's spelling indicates clearly that $/ \mathrm{j} /$ is required, as in "yers" for "ears" in the 1844 version of "Uncle an' ānt").

\subsection{LM}

Barnes notes the intrusion of an epenthetic vowel (which I take to be schwa) into the consonant cluster - $I m$ (as in some pronunciations of film in current English): "The liquids $l m$ at the end of a word are sometimes parted by a vowel, as in elem, elm; auverwhelem, overwhelm; helem, helm" (Diss., \32; 
similarly in the 1863 Grammar, p. 18, and 1886 Glossary, p. 15). This observation is borne out in his poems by both scansion and spelling: elm on its own or in final position is always disyllabic / $\mathrm{elom} /$ (as in line 4 of "The Spring," the first poem in the first collection), and its normal spelling is elem. The one occurrence of the form elm that I am aware of in 1844, in the third stanza of "The d'rection post" ("The Leyton road ha lofty ranks / Ov elm trees upon his banks"), is evidently a printing error: elm must be disyllabic for the metre, and the spelling is elem both in the version in DCC and in later editions.

The first line of the second stanza of "Faïr Emily ov Yarrow Mill" ("But thy wold house an' elmy nook") shows the accuracy of Barnes's observation that it is only "at the end of a word" that a vowel intrudes: the octosyllabic metre requires that elmy be disyllabic, making elm itself in this instance monosyllabic $/ \varepsilon 1 \mathrm{~m} /$. Similarly, the spelling calm and the metrical need for a monosyllable at the beginning of the penultimate line of the first stanza of "Lindenore" ("Calm air do vind the rwose-bound door") confirm that it is only "sometimes" that the consonant cluster $l m$ in final position is "parted by a vowel".

\section{$8.7 N$}

8.7.1 After $v$. In the 1886 Glossary Barnes explains how, in the dialect he is describing, the sequence $/ \mathrm{v}(\mathrm{\partial}) \mathrm{n} /$ may develop into the consonant cluster $/ \mathrm{bm} /$ via the intermediate stage $/ \mathrm{v}(\partial) \mathrm{m} /$ : "When $\mathrm{V}$ and $\mathrm{N}$ (either in $e n$ as a wordending, or the pronoun en) come together, the $v$ often overwields the $n$ which in its new form overwields the $v$ that becomes $b$ " (p. 14). In modern terminology (more Latinate and perhaps also more opaque than Barnes's resolute Anglo-Saxon) (alveolar) $/ \mathrm{n} /$ becomes (bilabial) $/ \mathrm{m} /$ through the influence of an adjacent (labiodental) $/ \mathrm{v} /$, which in its turn is converted by (the bilabial) $/ \mathrm{m} /$ into (the bilabial) $/ \mathrm{b} /$. The examples Barnes gives to demonstrate this phenomenon are ebm (/ibəm/) from even via ev(e)m (/irvəm/), together with elebm, habm, heabm, obm, sebm (from, respectively, eleven, have-en 'have him', Heaven, oven, seven). Since, however, Barnes never uses the spellings $b m$ or bem for ven in his poems, it seems that this is one feature of the dialect that he chose not to portray. The halfway stage shown 
in 1844 in his spelling of evening, on the other hand (always evemen in 1844, replaced by evenèn in later editions) suggests that his preferred pronunciation of this word (in his poems, at least) is /i:vmən/.

8.7.2 After $b$ or $p$. In a similar way, and for similar reasons, Barnes explains that the object pronoun en becomes (bilabial) $/ \mathrm{m} /$ under the influence of a preceding (bilabial) /b/ or /p/; thus robm (/rbbəm/) is developed from rob en ('rob him'), and drubm, mobm, rubm, scrubm, dropm and stopm from drub en ('drub him'), etc. (1886 Glossary, p. 14). None of this, however, is shown in his poems.

8.7.3 As a final twist Barnes points out that (voiced) $/ \mathrm{m} /$ or $/ \mathrm{n} /$ can have the effect of converting a preceding (voiceless) $/ \mathrm{p} /$ into (voiced) $/ \mathrm{b} /$; thus open (o:pən) is likely to become /o:bən/ or /o:bəm/ (1886 Glossary, p. 14). This feature is shown frequently in Barnes's poems: in 1844 open is always spelled oben; in later editions it may be either oben or open. There are, however, no spellings suggesting the pronunciation with /əm/ for /on/. In accordance with Barnes's 1844 spelling I transcribe open always as /o:bən/.

\section{$8.8 R$}

8.8.1 Whereas RP is a non-rhotic accent (that is to say, the $/ \mathrm{r} /$ sound originally heard in all words with $r$ in their spelling has now been lost when the $r$ appears at the end of a word or precedes a consonant), the SW is fully rhotic (i.e. $r$ is always sounded); indeed, as Wells says, "The preservation of historical $/ \mathrm{r} /$ in all environments is the best-known phonetic characteristic of the west of England" (4.3.5, p. 341). Thus the $r$ is audible (as it would be in GenAm) where it would be silent in RP in weather's, sparkle, toward, hear, and birds (to take some examples only from the first stanza of the first poem in Barnes's first dialect collection, "The Spring"); conversely, rhymes such as arm / calm and four / flaw, which have become normal in RP, are impossible for Barnes. Commentators have had a field day with the precise quality of this / $\mathrm{r} /$ sound; for the purposes of this guide, however, I note merely that the $/ \mathrm{r} /$ in Barnes's dialect poems will always be distinctly heard. 
8.8.2 Full rhoticity has a tendency to spill over into hyper-rhoticity, i.e. the insertion of an $/ r$ / sound where there is no etymological justification for it. This is especially likely to happen in words ending in unstressed -ow (yellow, hollow, window, etc., which become yeller, holler, winder, etc.: see 7.14.8).

8.8.3 " $r$ in great, pretty, undergoes metathesis, making ghirt and pirty" (Diss., \$34; see 7.9.4). The spelling ghirt (for which see 8.4.1) is not used in Barnes's poems; but the metathesis of $r+$ vowel is consistently shown in the spellings girt or gert in almost all editions, as in the titles of two of his best-loved poems, "The girt woak tree that's in the dell" and "The settle an' the girt wood vire." (The misleading spelling gre't that is sometimes used in the third and fourth editions of the first collection is abandoned thereafter.) Pretty is always pirty in 1844, and thereafter either perty or pretty; I take it, however, that the pronunciation is always /pərti/, and that of great always /gərrt/.

8.8.4 "The liquids $r l$ of English words, such as purl, twirl, world, have frequently $d$ inserted between them, making purdle, twirdle, wordle ..." (Diss., \33). Barnes's spelling in 1844 accords with his comment in the Dissertation, curl, twirl, whirl and world all being spelled with -rdle (and pronounced, I take it, with -/ərrdəl/), and worlds ("wordles") rhyming with burdles in stanza 7 of “The Shepherd o' the farm”: “An' wi' my zong, an' wi' my fife, / An' wi' my hut o' turf an' hurdles, / I wou'den channge my shepherd's life / To be amiade a king o' wordles." But this stanza is omitted from later editions; world is respelled worold (thus keeping it disyllabic); and the other words are respelled as in StE (with compensatory adjustments to the wording where the loss of a syllable would disturb the rhythm) or with -rrel for -rdle (as in the maidens' "currels" in the second stanza of "Evenèn, an' maïdens out at door"). It seems clear, then, that Barnes decided not to portray the characteristic SW -/ardəl/ for -/arrl/ in later editions of his poems. We are left, then, with several possible pronunciations for words in this subset: -/arrdəl/ (as in 1844), -/arrl/ (as in StE), and -/ $\mathrm{ar}$ rəl/ or -/ərrəl/ (as implied by the spelling currel for curl). The first three of these are all offered as possible pronunciations for curl and purl in Barnes's contribution to EEP for Winterborne Came (cwl 805a-b). 
8.8.5 " $r$ before a hissing palate letter, $s, \mathrm{c}$, or $\mathrm{z}$, or $t$, as in burst, first, verse, force, furze, nurs'd, mirth, earth, birth, worth, is thrown out, making bust, vust, vess, fuoss, vur\%, nuss'd, meth, eth, beth, woth" (Diss., \$35). This observation is consistently borne out by Barnes's spelling: see 7.8.4, 7.22.4, and 7.9.5.

8.8.6 For possible aspiration of initial $r$-, resulting in the pronunciation $/ \mathrm{hr} /$, see 8.5.2.

\{8.8.7 Loss of / $\mathrm{r} /$ before final / $\mathrm{d} /$ in an unstressed syllable is shown in the spellings archet and orcha'd for orchard and Richat for Richard (this latter in "Eclogue: Emigration"); conversely the forms shepherd and Roberd (the usual 1844 spelling of Robert) show its retention in some words.\}

\section{$8.9 S$}

8.9.1 " $S$ before a vowel often but not universally becomes in Dorset its smooth kinsletter ₹, making sand, zand; sap, zeap; send, zend; set, zet; sick, zick; some, zome; sop, zop; and sun, zun" (Diss., \$36; see \$17 for Barnes's explanation of the terms rough and smooth). To this may be added $s$ before $w$ (since there are many occurrences of zw- spellings—zwath, zweat, zwell, zwing, etc.), together with the plurals of face and place (-ren as opposed to -ces). Since, however, there is no certain way of predicting when the $s$ - will be voiced and when not, Barnes's "often but not universally" seems as precise a formulation as one could hope for, and his decision to retain the z-spellings of affected words in later editions is much to be welcomed. \{Nevertheless line 9 of "Early plaÿmeäte" ('There wer zome things a-seemèn the seäme') shows that the spelling is not always to be trusted, since the triple alliteration in the penultimate line of each stanza in this poem demands $/ \mathrm{s} /$ here rather than $/ \mathrm{z} /$ for some.\}

8.9.2 "In many English words ending with $s$ and a mute consonant, those letters have undergone metathesis, since in Anglo-Saxon the $s$ followed the consonant, as it does in the Dorset dialect; in which clasp is claps; crisp, crips; hasp, haps; wasp, waps; and to ask, to aks (ax), the Anglo-Saxon axian" (Diss., \$37). To the best of my knowledge the only word in this list that occurs in Barnes's poems is ask: in accordance with his comment here it is always spelled ax (/akks/).There is also the word clips, which occurs, always 
in the infinitive, in five of Barnes's poems ("The sky a-clearèn," "The wold vo'k dead," "Brookwell," "Shop o' meat-weäre, and "The little hwomestead"), and which is defined and exemplified in the 1844 Glossary (with a cross reference to $\$ 37$ of the Diss.) as "To clasp between the thumb and fingers, or between the two arms. I can clips thik tree."

\subsection{3}

The voiced $s(/ \mathrm{z} /)$ in isn't and 'tisn't is replaced by /d/, as shown by Barnes's consistent spellings idden and tidden in both early and late collections.

\subsection{SH and $S$ representing $/ \mathrm{S} /$}

Voicing of initial $/ \mathrm{S} /$ to $/ 3 /$ is a characteristic of SW dialects generally considered to be as firmly established as voicing of initial /s/ to /z/ (Wells, 4.3.6, p. 343; Wakelin, I.4.2, p. 29), but it is a feature not normally shown by Barnes. There is one isolated example of zure for sure in John's final speech in the 1844 version of "The common a-took in" amongst many examples of sure elsewhere in the collection; in later editions, however, it has been altered to sure. I transcribe sure, accordingly, always with initial $/ \mathrm{S} /$.

\subsection{SHR}

The spelling of 1844 indicates simplification of the consonant cluster $/ \mathrm{Sr} /$ to $/ \mathrm{S} /$ by loss of $/ \mathrm{r} /$, as in Shodon and sh'oud for Shroton and shroud. The $-r$ - is often (but not always) restored in later editions, suggesting that pronunciations with $/ \mathrm{gr} /$ and $/ \mathrm{S} /$ were both acceptable. Shrill is perhaps a special case: Barnes's preferred spelling in 1844 is shill (three occurrences, in "The woodlands," "The blackbird," and "The music o' the dead," as against one occurrence of shrill, in "The woody holler"). The spelling shill (as against sh'ill, which does not occur in 1844) may suggest that the word in question is not in fact shrill with loss of $-r$ - but the more or less synonymous shill (from OE scill 'sonorous, sounding'; EDD, shill, adj. ${ }^{1}$ ). But this is not certain: the form shill is abandoned in later editions; its three occurrences in the First Collection are all replaced by shrill, and elsewhere the spellings sh'ill and shrill are both frequently used. 


\section{$8.12 T$}

8.12.1 Intervocalic / $t$ / is generally said to be voiced throughout the SW (as in GenAm): " $L A E$ shows butter with [d] everywhere south-west of a line from Weston-super-mare to Portsmouth" (Wells, 4.3.6, p. 344). But the situation is not quite so clear-cut. Barnes seems always to have $/ \mathrm{t} /:$ he gives no indication of $/ \mathrm{d} /$ either in his grammars or in the spelling of his poems \{except very rarely, as in nodice for notice in the 1844 and 1847 versions of "Eclogue:-A bit o' sly coortèn"\}, and his contribution to EEP has / $\mathrm{t} /$ in little and kettle (cs, clauses 10 and 12), the only eligible words for which his responses are recorded.

8.12.2 "An open palate letter is sometimes substituted for a close one" (cf. 8.2.1 above), in this instance “ $k$ for $t$; as ... pank, to pant" (Diss., \$39). To the best of my knowledge pant is the only word in which $/ \mathrm{k} /$ replaces $/ \mathrm{t} /$ in this way; it is always shown by Barnes's rhyme and spelling, in both early and late editions, as in the rhyming of pank with bank ("Dock leaves", "John Bloom in Lon'on") and spank ("John Bloom in Lon'on").

\subsection{TH (excluding THR)}

8.13.1 "Where the English rough articulation th, as in thin, the Anglo-Saxon p, becomes in Dorsetshire its soft kinsletter th as in thee, the Anglo-Saxon d, as it does very frequently, the author has printed it in Italics th, as think" (Diss., (38). That is to say, when voiceless th is voiced (as it frequently is in Dorset) Barnes prints the th in italics in 1844 (replaced by $\partial$ in 1847); if the th is voiceless in RP and is not printed in italics in 1844, we may assume that it remains voiceless in Barnes's dialect. This statement does not propose any rule by which we can predict when th will be voiced and when not: as with voiced and voiceless $s$, we are in the territory of "often but not universally" (see 8.9.1 above). This would be of little concern to readers if Barnes had stuck to his policy of indicating typographically when voiceless th becomes voiced; the problem is that he abandoned this policy in later editions, in which he gives no indication as to when a th that is voiceless in StE is to be voiced. It may therefore be helpful to list here all words in which voiceless th in RP is shown to be voiced in the poems and/or glossaries of 1844 and 
1847, the 1879 Glossary, and the 1886 Glossary (p. 9): athirt and thirtawver, both and loth, thatch, thaw, thief, thiller and thillharness, thik, thimble, thin (adj.), thin (v.), thing, think and thought (v.), thistle, thorn, thumb. (Words with voiced th in RP in which the th is superfluously italicized in 1844 are omitted from this list.) The only words in which initial th is not shown to be voiced in 1844 are thick, thigh, thought (noun, and in the compounds thoughtful and thoughtless), thousand, thump, and thunder. \{It is not clear whether the single instance of italicized th- in thought, noun, in 1844 (in "The happy daes when I wer young") is an oversight, or whether it shows that both voiced and voiceless pronunciations were acceptable. $\}$ In the transcription of his poems I have relied on Barnes's typographical conventions in 1844 and 1847 and on his lists of the words in which th is voiced.

8.13.2 In a sentence added to $\$ 38$ in the expanded Dissertation of 1847 Barnes notes the loss of medial or final th in some words: "th go out in wi', for with; gramfa'r, grandfather; grammo'r, grandmother; le's, let's." (The placement of let's in this list of words with omitted th is evidently a slip.) In the poems (both early and late editions) grandfather and grandmother are always spelled gramfer and grammer, evidently with $/ \mathrm{m} /$ for $/ \mathrm{nd} /$ and a final syllable reduced to /or/. With is occasionally spelled out in full, but usually it is $w i$, "pronounced wee" according to the 1844 Glossary. This implies lengthening as well as raising of the vowel (cf. gi'e for give, 8.15.1); since, however, wi' is rarely stressed, the likelihood must be that the sound is usually that of the "the happY vowel" (see 7.1.2), namely /i/ rather than /i:/.

8.13.3 Though not included in Barnes's list in the preceding paragraph, clothes is evidently another word in which medial /ð/ is lost, as shown both by the spellings cloas or cloaz in 1844 and by rhymes on the sound /o:z/ (e.g. a-vroze "The vrost", shows "Martin's tide"). That these rhymes are retained in later editions even when clothes has its StE spelling suggests that the pronunciation for Barnes is always /klo:z/, irrespective of the spelling.

\subsection{THR}

" $d$ is substituted for initial th; as drow for throw; droo, through; drash, thrash; drong, throng; droat, throat; drashel, threshold" (Diss., §29). In the 1863 Grammar Barnes points out that this substitution takes place "mostly before 
$r$ " (p. 16); his examples suggest that it happens only before $r$. In phonemic terms initial $/ \theta \mathrm{r} /$ becomes $/ \mathrm{dr} /$, a feature widely noted by commentators on SW dialects. (Except in a few stray instances the $d r$-spellings are reinstated in Barnes's 1879 edition, though some had been abandoned in intermediate editions after 1844.) The sole exceptions to the substitution of $/ \mathrm{dr} /$ for $/ \theta \mathrm{r} /$ in Barnes's poems are thrive and thrill; it may be that $/ \theta \mathrm{r} /$ is retained in thrill to prevent confusion with drill, but possible confusion between thrive and drive can hardly be urged as a cause for its retention in thrive, since drive has a different vowel in Barnes's dialect (see 7.10.6).

\section{$8.15 \mathrm{~V}$}

8.15.1 " $v$ is sometimes omitted, as gi'e, give; ha', have; sar, serve" (Diss., \40). Barnes's spelling in his poems suggests that in have the /v/ may be included or omitted indifferently; in serve it is usually omitted, but may be retained in rhyme where needed (as in sarve ye/starve ye, "Eclogue: The times"); in give it is normally omitted, but sometimes retained in derived forms such as givèn. Rhymes show that when $/ \mathrm{v} /$ is omitted from give, the vowel is raised and lengthened, producing the form /gi:/ (as in gi'e/be, "Eclogue: Father come huome").

8.15.2 For the sequence $/ \mathrm{v}(\boldsymbol{\partial}) \mathrm{n} /$ see 8.7.1.

\section{$8.16 W$}

8.16.1 Loss of initial /w/ is a common feature in SW dialects, but since it is a feature on which Barnes makes no comment, the only safe policy is to be guided by the spelling of 1844: his usual spelling of within and without is with no initial $w$, but there are occasional occurrences of without spelled as in StE, suggesting that forms with and without initial /w/ are both acceptable; will is usually wull but occasionally will, 'ool, or 'ul(l), so that /wol/, /wil/, and / $\mathrm{ul} /$ are all possible; would is variously would, woud, wou'd, wood, woo'd, 'ood, or 'od, so that /wud/ and /ud/ are evidently both possible, even though the spellings without initial $w$-are abandoned in later editions. Where, on the other hand, Barnes never uses spellings without $w$ - in his poems (as with woman, women, 
wood, and wool), I assume that he wished initial /w/ to be retained. For one and once, both of which have initial /w/ in RP, see 7.5.7.

8.16.2 Loss of medial /w/ in words such as upward is common in regional dialects throughout England and sometimes reflected in Barnes's spelling. Athwart is always athirt (the italicized th in the spelling of 1844, "athirt," showing that loss of $/ \mathrm{w} /$ is accompanied by voicing of the preceding $/ \theta /$ to /ð/, hence /əðərrt/, see 8.13.1); somewhat is variously zome'bat, zome'at, or zummat, all of which I take to be /zımət/.

8.16.3 As Wakelin points out, in SW dialects / w/ may be added initially or after a preceding consonant before long back vowels, "but its interpretation is open to question" (I.4.4, p. 33). In Barnes's case insertion of /w/ before /a:i/ appears to be normal in boil, spoil, point, poison, toil, and boy (see 7.17.1 and 7.17.4). On the interpretation of the $w$-glide before the sound traditionally called "long 0 " see 7.14.1-4.

\section{$8.17 \mathrm{WH}$}

8.17.1 On the question of aspiration in words containing $w h$ - see 8.5.3.

8.17.2 Loss of medial $w h$ is shown in spellings such as zummat for somewhat (see 8.16.2).

\section{$8.18 Y$}

When ye is grammatically dependent on the preceding word, its initial $/ \mathrm{j} /$ is frequently lost and the /i:/ assimilated to the preceding word. Thus can ye sounds like canny and rhymes with Fanny ("Eclogue:-A bit o' sly coortèn"); tellye sounds like telly and rhymes with belly ("Eclogue:-The times"), and so on. 


\section{By the same author}

The Complete Poems of William Barnes. (Ed. with K. K. Ruthven.) 3 vols. Oxford: Oxford UP. 2013-.

Six Eclogues from William Barnes's Poems of Rural Life in the Dorset Dialect (First collection, 1844) with phonemic transcripts and an audio recording from the 2010 Adelaide Fringe. Adelaide: Barr Smith Press, 2011.

William Barnes's Dialect Poems: A Pronunciation Guide. Adelaide \& Provo: Chaucer Studio Press. 2010.

The Vaices That Be Gone: Selected Poems from William Barnes's Poems of Rural Life in the Dorset Dialect (First collection, 1844) with phonemic transcripts and an audio recording from the 2009 Adelaide Fringe. Adelaide \& Provo: Chaucer Studio Press, 2009.

Long Words Bother Me, with illustrations by Michael Atchison. Stroud, Glos: Sutton, 2004. (A revised and expanded reprint of Words, Words, Words and Words in Your Ear.)

Sidrak and Bokekus: A Parallel-Text Edition from Bodleian Library, MS Laud Misc. 559 and British Library, MS Lansdowme 793. 2 wols. Earby English Text Society, 311 and 312. Oxford: Oxford UP, 1998-99.

Words in Your Ear, with illustrations by Michael Atchison. Adelaide: Wakefield Press, 1998.

Words, Words, Words, with illustrations by Michael Atchison. Adelaide: University Radio 5UV, 1995. 


\title{
Electronic Index
}

\author{
This book is available as a free fully-searchable \\ ebook from
}

www.adelaide.edu.au/press

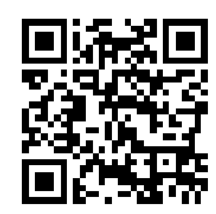

